\author{
UNIVERSIDADE DE SÃO PAULO \\ Faculdade de Filosofia, Letras e Ciências Humanas \\ Departamento de Letras Clássicas e Vernáculas \\ Programa de Pós-Graduação em Filologia e Língua Portuguesa
}

\author{
ANDREA COLSATO
}

\title{
ORGANIZAÇÃO HIERÁRQUICA E LINGUÍSTICA: \\ O MODELO JESUÍTICO APÓS A RESTAURAÇÃO
}

\author{
São Paulo
}

Versão corrigida

Fevereiro 2017 


\author{
UNIVERSIDADE DE SÃO PAULO \\ Faculdade de Filosofia, Letras e Ciências Humanas \\ Departamento de Letras Clássicas e Vernáculas \\ Programa de Pós-Graduação em Filologia e Língua Portuguesa
}

\author{
ANDREA COLSATO
}

\title{
ORGANIZAÇÃO HIERÁRQUICA E LINGUÍSTICA: O MODELO JESUÍTICO APÓS A RESTAURAÇÃO
}

Tese apresentada ao Programa de Pós-Graduação em Filologia e Língua Portuguesa do Departamento de Letras Clássicas e Vernáculas da Universidade de São Paulo como requisito parcial para a obtenção do título de Doutora em Letras.

Orientadora: Prof. Dra. Marilza de Oliveira

São Paulo

Versão corrigida

Fevereiro 2017 
COLSATO, Andrea. Organização Hierárquica e Linguística: o modelo jesuítico após a restauração. Tese apresentada ao Departamento de Letras Clássicas e Vernáculas da FFLCH/USP para a obtenção do título de Doutora em Letras.

Aprovada em:

Banca Examinadora:

Prof. Dr.

Instituição:

Julgamento:

Assinatura:

Prof. Dr.

Instituição:

Julgamento:

Assinatura:

Prof. Dr.

Instituição:

Julgamento:

Assinatura:

Prof. Dr. Instituição:

Julgamento: Assinatura:

Prof. Dr. Instituição: Julgamento: Assinatura: 
Para meus queridos filhos:

Nathália,

Vitória,

Gabriel. 


\section{Agradecimentos}

Si hubiera una sola verdad, no se podrían hacer cien lienzos sobre un mismo tema.

Pablo Picasso

Este trabalho é fruto de diálogos. Numerosos diálogos. Com pessoas com quem pude compartilhar a grande experiência da troca humana, seja pelos livros que escreveram, pelas ideias que compartilharam, ou pelo simples aconchego do entendimento. É essa possibilidade de troca que faz a jornada mais rica, menos dolorosa e que permanece na memória.

As casas de café paulistanas nunca mais serão as mesmas. Foi entre um café e uma fogazza que este trabalho foi se delineando; e, esse acolhimento quente tem relação com as muitas vozes que compõem este trabalho. Tudo começou num daqueles sábados pela manhã em que o grupo se reunia, num café, para discutir Bakhtin e Dostoievsky.

Por essa possibilidade tão boa de compartilhar, devo agradecer primeiramente à minha orientadora, Doutora Marilza de Oliveira, por quem tenho o mais profundo respeito intelectual e a mais longa gratidão acumulada ao longo dos mais de dez anos que durou nossa relação de orientação entre o mestrado e o doutorado. Foi através dela que conheci pessoas - algumas das muitas vozes - com quem saboreei cafés em tantos lugares diferentes.

Expresso aqui meu sincero agradecimento à equipe do Colégio São Luís; principalmente à Gládis, ao Leonardo e a todo o pessoal da biblioteca, pessoas sempre solícitas, que me receberam e disponibilizaram um pouco de seu tempo e conhecimento e que abriram a porta daquela salinha com a placa "acervo antigo" para que eu pudesse iniciar minha incursão nesse vasto mundo que é o dos jesuítas. Meu último encontro não poderia ter sido senão para tomar um café na Padaria Bela Paulista, logo embaixo do prédio do Colégio.

Agradeço aos Padres jesuítas que, mesmo indiretamente, possibilitaram essa pesquisa. Ao Pateo do Collegio e ao Museu de Arte Sacra de Embu das Artes, onde pude participar de diversos encontros e conhecer inúmeras pessoas envolvidas com o tema dos jesuítas.

Em Itu, ao Museu Republicano e aos funcionários sempre gentis que separaram livros e me ensinaram a consultar os acervos on-line. 
Ao Luís Francisco, do Museu da Música, grande mestre que, depois da qualificação deste trabalho, verdadeiramente redirecionou minha pesquisa ao permitir meu acesso aos documentos do acervo ainda fechado da Igreja do Bom Jesus.

Agradeço aos professores João Adolfo Hansen e Hélcius Pereira Batista pela gentileza de participarem da minha Banca de Qualificação e pela contribuição inestimável que prestaram à condução deste trabalho. Agradeço por compartilharem seus conhecimentos, pelo empréstimo de livros e por tornarem a situação tão agradável.

Sou grata à Banca de Defesa, os professores Antônio Lindvaldo, Helena Brandão, Hélcius Pereira Batista e Priscilla Ribeiro, pelo profissionalismo e dedicação à pesquisa. Obrigada pela generosidade dos comentários, pela leitura criteriosa e pelas preciosas contribuições.

Também tenho uma gratidão imensa pela Associação Escola Graduada de São Paulo, o lugar onde eu trabalho há 11 anos e onde fiz grandes amigos pra longas conversas e inúmeros cafés. Agradeço à direção do Departamento Brasileiro: Gila, Eloísa, Karen pelas possibilidades de professional developments que me levaram a Congressos de Língua Portuguesa por tantos lugares incríveis.

Agradeço a dois queridos amigos, Breno e Cristal, pela leitura dos remendos de texto, pelos livros emprestados e pelo tempo que puderam me dedicar. $O$ trabalho não teria sido tão divertido sem vocês!

Aos companheiros de jornada: Érica, Giovana, Priscilla, Fernanda, obrigada pela amizade e disponibilidade!

À minha família e, principalmente, aos meus filhos, que cresceram e, hoje, compartilham desses inúmeros diálogos.

Enfim, estou grata e feliz por este trabalho ter terminado (ou não!). Que ele possa trazer muitos outros diálogos - essa é a finalidade para a qual ele foi feito, nenhuma outra pretensão além dessa. 


\section{RESUMO}

A investigação interdisciplinar proposta neste trabalho envolve uma análise linguística e social das práticas jesuíticas após a restauração da Companhia de Jesus quando a Igreja Católica passou a produzir uma memória apologética da ação da Ordem, reverberando uma ideologia civilizatória cujo personagem principal é o Pe. José de Anchieta. No século XIX, a Companhia retomou seu projeto pedagógico, investindo na criação de seminários e colégios, entre os quais se destaca o Colégio São Luís, fundado em Itu, cujos religiosos, responsáveis pela educação de setores católicos das elites paulistas, protagonizaram a oposição ao crescente laicismo republicano e ao Protestantismo que começava a se expandir na região devido à imigração norteamericana.

Os discursos e panegíricos pronunciados na primeira década do século XX por ocasião das festividades do Colégio captam a "voz jesuítica" e um conjunto de representações de valores religiosos que, ao lado dos textos de jornais, articulam as ideias e polêmicas que circulavam naquele momento. Como objeto de estudo, destacamos a repetição de estruturas linguísticas, assumindo a hipótese de que há uma relação entre repetição de estruturas e reiteração de tópicas. Destacamos ainda a questão da colocação pronominal, verificando se a padronização linguística adotada pelo grupo segue o modelo do Português Europeu ou se atende o modelo brasileiro de português culto.

Nesse sentido, este trabalho procurará evidenciar: Qual o imaginário jesuítico que se pretendia fixar para os ouvintes? Que bens culturais, sociais e simbólicos os jesuítas procuravam transmitir pela via educacional, com a criação do Colégio São Luís, voltado para os filhos da elite ituense? Quais meios linguísticos foram utilizados para a transmissão desses bens?

Palavras-chave: clítico, repetição, jesuítas, restauração, Colégio São Luís 


\section{ABSTRACT}

This interdisciplinary research aims to investigate the linguistics and social practices of the Jesuits after the restoration when the congregation produced an apologetic memory of their actions, reverberating a civilizing ideology whose main character is Fr. José de Anchieta.

In the nineteenth century, the Society of Jesus resumed its pedagogical project, investing in the foundation of Seminaries and Schools, among which stands out the São Luís School, founded in Itu. The Jesuits were responsible for the education of Catholic sectors of the São Paulo elites, in the context of growing secularism and Protestantism that came with the North American immigrants.

The Graduation Speeches and Panegyrics pronounced in the early years of the twentieth century by occasion of the School festivities capture the "Jesuitical voice" and other set of religious values representations that, in articulation with the Newspaper Texts, show the controversial ideas circulating at that time.

This research highlights as a literary device, the repetition of structures, inferring the connection between repeating structures and topic reiteration. It also highlights the clitic position, in order to understand whether the model used is the Brazilian Portuguese or the European Portuguese.

In this sense, this research will seek to answer the questions: What is the Jesuit imaginary spread for the audience? What are the cultural, social and symbolic assets transferred in their texts? What are the linguistic tools used to convey their ideas?

\section{Keywords: clitics, repetition, Jesuits, restoration, São Luís School}




\section{SUMÁRIO}

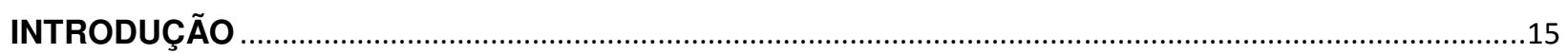

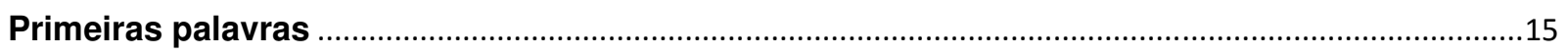

PARTE 1 - Intersecções teóricas: traçando possibilidades de diálogos ....................................21

PARTE 2 - Acervos: memória, identidade e história do português paulista ................................27



Biblioteca Histórica da Igreja do Bom Jesus .........................................................................

CAPÍTULO 1 - A QUESTÃO GERAL: O programa da Companhia de Jesus .......................................58

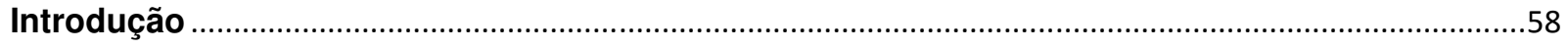



1.2 - As Constituições - mobilidade, hierarquia e obediência ….................................................59

1.3 - Os colégios e a concepção educacional dos jesuítas - o Ratio Studiorum ...........................63

1.4 - A disseminação dos ideais jesuíticos - definição e controle do conhecimento......................66

1.5 - A proposta jesuítica de educação no Brasil colônia..............................................................68

CAPÍTULO 2 - A QUESTÃO LOCAL: Os jesuítas em Itu ...............................................................71

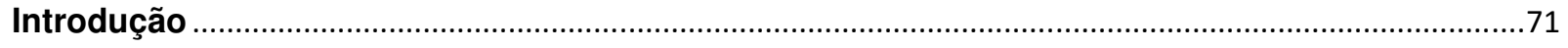

2.1 - A retomada educacional dos jesuítas no Brasil do século XIX - tarefa doutrinária e

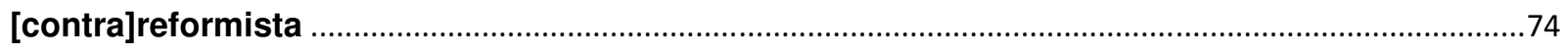

2.2 - Colégio São Luís de Gonzaga - rotina escolar e matérias ensinadas …................................83

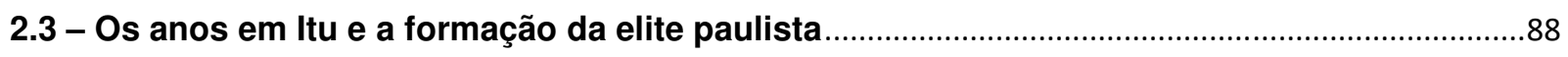

CAPÍTULO 3 - A “REPETIÇÃO” COMO ESTRATÉGIA DA CONSTRUÇÃO DO IMAGINÁRIO JESUÍTICO 
3.1 DOS DISCURSOS

3.1.1 A fundação mítica e legendária do colégio .............................................................................

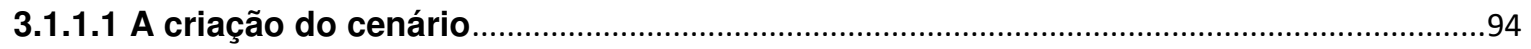

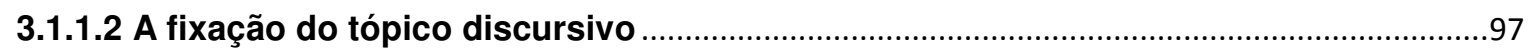

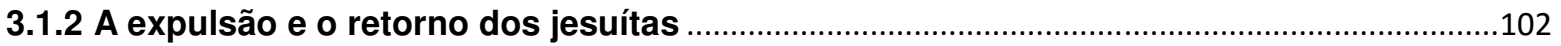

3.1.2.1 A (des)articulação dos espaços físicos e mentais .......................................................105

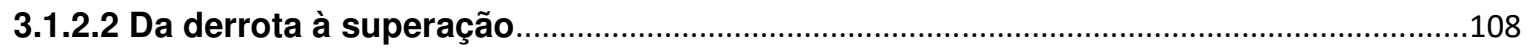

3.1.3 A solidez, a permanência e a persistência do edifício jesuítico ............................................112

3.1.4. A idealização do jesuíta como libertador .............................................................................118

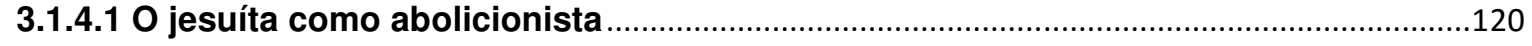

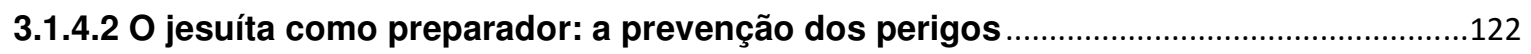

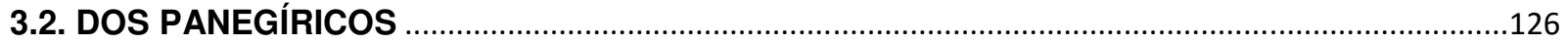

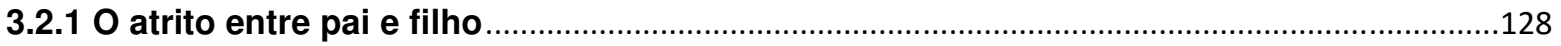

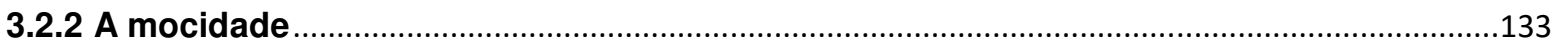

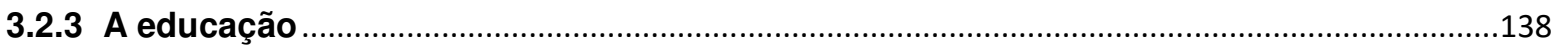

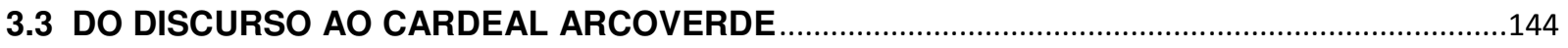

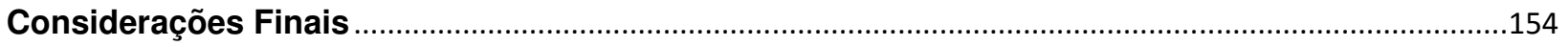

CAPÍTULO 4 - COMUNIDADES DE PRÁTICA E USOS LINGUÍSTICOS: O PADRÃO JESUÍTICO DE

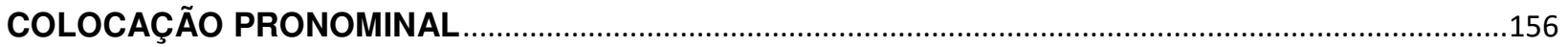

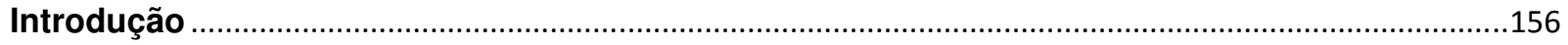

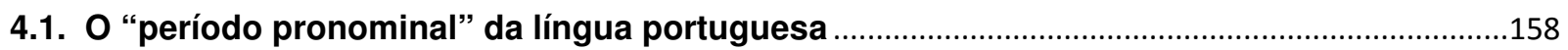


4.2. A colocação pronominal do interior paulista: $O$ modelo jesuítico confrontado

4.2.1. A moldura pronominal: orações finitas .162

4.2.2 Comunidades de prática em evidência 167

4.2.2.1 A pintura pronominal nas comunidades de prática .....................................................167

4.2.2.2 Textos jornalísticos e discursos: tonalidades pronominais ......................................173

4.2.2.3 Orações finitas nas comunidades de prática: uma sintaxe comum? ……….............176

4.2.3 0 quadro pronominal dos grupos verbais ........................................................................177

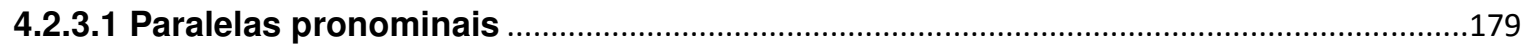

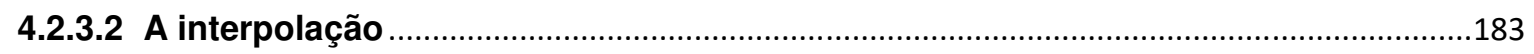

4.2.4. Colocação pronominal em perspectiva: o caso das infinitivas .........................................185

4.2.4.1. A moldura pronominal: orações infinitivas …............................................................185

4.2.4.2 Traçados pronominais nas infinitivas preposicionadas ............................................190

4.2.4.3 De jesuíta a jesuíta: de Vieira ao interior paulista ....................................................193

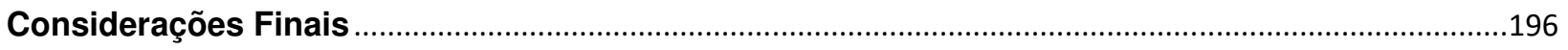

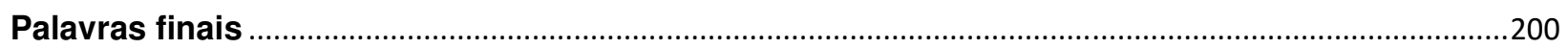

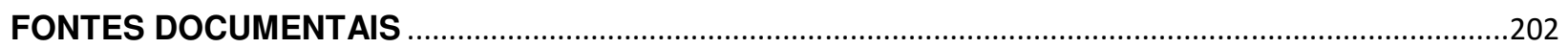

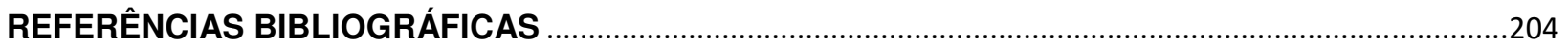

ANEXOS 


\section{Lista de figuras, gráficos, tabelas e quadros}

\section{Figuras}

Figura 1 - Discurso pronunciado no acto da Collação de Gráu aos Bacharelandos em Sciencias e Lettras no Collegio S. Luiz em Ytú - Dr. Reynaldo Porchat, p.34

Figura 2 - Capa e Contracapa da Encadernação do Echo das festas collegiaes em honra a S.Luiz Gonzaga e Homenagem ao eminentissimo senhor cardeal D. Joaquim Arcoverde de A.Cavalcanti Collegio de Ytú - 1906, p.38

Figura 3 - Capa interna do Discurso proferido em Ytú pelo Dr. Brasilio Machado na sessão solemne do Collegio S. Luiz - 2 de Julho de 1906, p.41

Figura 4 - Capa interna do Panegyrico de S. Luiz Gonzaga pregado em Ytú no dia 30 de Junho de 1906 pelo Pe. André Fialho S.J.,p.42

Figura 5 - Revista Mensageiro do Coração de Jesus - Typografia a vapor do Apostolado - Ytú (S. Paulo), p.48

Figura 6 - Jornal A Federação - Orgam das Associações Catholicas de Ytú - 13 de outubro de 1907, p.51

Figura 7 - Jornal República - Orgão Republicano - Março de 1904, p.52

Figura 8: Cartão-postal com vista do Collegio S.Luiz, 1912, p.72

Figura 9: Cartão-postal do Collegio de S.Luiz, 1909, p.82

Figura 10: Dormitório dos alunos, Itu, 1903, p.85

Figura 11: Alunos de Primeiras Letras - P.Soriani, 1899, p.86

\section{Gráficos}

Gráfico 1: Diacronia da ênclise nas orações não-dependentes (adaptado de Martins, 1997), p.164

Gráfico 2: Próclise/Ênclise em orações dependentes por falante (Adaptado de Santos Silva, 2012), p.166

Gráfico 3: Interpolação da negação ao longo dos séculos (Adaptado de Martins, 1997), p.183

Gráfico 4: Ênclise em orações infinitivas preposicionadas: Escritores portugueses oitocentistas (Adaptado de Oliveira, 2011), p.186

Gráfico 5: Ênclise em orações infinitivas preposicionadas: Escritores brasileiros (Adaptado de Oliveira, 2011), p.187

Gráfico 6: Ênclise em orações infinitivas preposicionadas: Correspondência de circulação pública escrita no Brasil (Adaptado de Oliveira, 2013), p.188

Gráfico 7: Ênclise em orações infinitivas preposicionadas: Intelectuais republicanos paulistas (Adaptado de Santos Silva, 2012), p.189

Gráfico 8: Ênclise em orações infinitivas preposicionadas: Escritores portugueses (Adaptado de Godoy, 2006), p.193 
Gráfico 9: Ênclise em infinitivas preposicionadas: Autores portugueses seiscentistas (Adaptado de Godoy, 2006), p.194

Gráfico 10: Ênclise em infinitivas por tipo de preposição: Comparação jesuítas entre séculos, p.195

\section{TABELAS}

Tabela 1: Distribuição de ênclise por tipo de oração, p.170

Tabela 2: Ênclise por tipo de elemento que ocupa a 1르 posição sentencial, p.172

Tabela 3: Distribuição de ênclise: comunidades de prática, p.173

Tabela 4: Ênclise por tipo de oração: comunidades de prática, p.174

Tabela 5: Ênclise por tipo de elemento na 1a posição sentencial: nas comunidades de prática, p.175

Tabela 6: Distribuição dos clíticos em grupos verbais (Adaptado de: Lobo 2001, Carneiro 2005, Martins 2009, Santos Silva 2012), p.178

Tabela 7: Distribuição dos clíticos nos grupos verbais: comunidades de prática, p.181

Tabela 8: Ênclise nas infinitivas preposicionadas por tipo de preposição, p.191

Tabela 9: Ênclise nas infinitivas preposicionadas por grupo e tipo de preposição, p.192

\section{QUADROS}

Quadro 1: Posições do clítico X alçamento, p.177 


\title{
Lista de Siglas e Abreviaturas
}

\author{
CLS - Colégio São Luís \\ SJ - Societas lesu, "jesuíta" \\ IHS - lesus Hominum Salvator, "Jesus Salvador dos Homens" \\ SCJ - Sagrado Coração de Jesus \\ PB - Português brasileiro \\ PE - Português europeu \\ PA - Português arcaico \\ PC - Português clássico \\ PM - Português médio \\ cl - clítico \\ V- verbo \\ V1 - verbo na primeira posição da sentença
}


(...) os espiritos voltam agora, illuminados de esperanças, a procurar abrigo no porto remansoso onde brilha o ideal da fé, para verem (...) se dahi dimana alguma coisa que dê uma resposta menos desoladora, do que o anniquillamento offerecido pelos homens da sciencia.

Vós, que sois a primeira turma de bachareis a preceder tantas outras que hão de sair deste Gymnasio, empunhae, nessa vanguarda de honra, o lábaro da fé, que é o symbolo da fraternidade...

Reynaldo Porchat, 1904 


\title{
INTRODUÇÃO
}

\begin{abstract}
Anchieta tanto surge, evocador e nostalgico, a bordar de poesias o abamado de nossas praias, como vem - capitão em conquista - luctando contra os homens e contra os elementos, transpondo as serras azues e as mattas verdes e investindo contra perigos sem nome, semear a palavra de Christo, amanhar a terra e fundar São Paulo, como se plantasse um viveiro de almas predestinadas a transportar o progresso por todos os recantos do Brasil. ${ }^{1}$
\end{abstract}

Julio Prestes

\section{Primeiras palavras}

Em honra de seu patrono, o Colégio de São Luiz, na primeira década do século $X X$, é palco de festejos em homenagem ao recém-nomeado Cardeal D. Joaquim Arcoverde em visita às instalações do Colégio, evento conhecido como Echo das Festas Collegiaes, e da formatura dos alunos do ginásio cujos paraninfos, representantes da sociedade civil ${ }^{2}$, discursaram sobre as práticas jesuíticas. Parodiando Neves $^{3}$ (1978), os discursos das autoridades do governo civil reunidos em brochuras e publicados pela gráfica Duprat \& Cia e pela Typographia Brazil de Carlos Gerke \& Cia são um "imenso ruído", porque repetem o imaginário dos jesuítas os quais se reinventavam em terras brasileiras e se reafirmavam, amparados pela criação da figura mítica de José de Anchieta no contexto das Conferências anchietanas proferidas no final do século XIX.

\footnotetext{
${ }^{1}$ Ao longo de todo o trabalho, mantivemos a grafia das palavras usadas nas fontes primárias.

${ }^{2}$ Os representantes da sociedade civil mencionados serão apresentados na Parte 2 desta Introdução. Na epígrafe deste capítulo, o fragmento do discurso de Julio Prestes, de 1910, em que recupera a figura de Anchieta como modelo a ser seguido pelos formandos.

${ }^{3}$ Em oposição ao silêncio em torno da figura jesuítica na historiografia brasileira, Neves usa o termo "imenso ruído" para tratar da reiteração da fala jesuítica por meio de suas práticas pedagógicas.
} 
Cem anos após a expulsão pombalina, a Companhia de Jesus se reinseriu no Brasil graças ao afrouxamento da lei de permissão de entrada de ordens religiosas europeias para atuarem na educação. No vácuo dessas ordens, a Companhia de Jesus investiu na criação de seminários e colégios. Na América do Sul, a começar pela Argentina, os jesuítas retomaram seu propósito de consolidar os valores do catolicismo e se puseram rumo ao Brasil iniciando suas atividades em Porto Alegre e na cidade de Desterro. A ação concreta começou a ganhar vigor ao chegarem no Sudeste do país que teve, na cidade de ltu, o estabelecimento do colégio jesuítico. A cidade, um dos principais polos de produção de cana-de-açúcar que serviu de base para a ascensão da cultura cafeeira ${ }^{4}$, colocava-se como um lugar ambíguo pela "disputa do domínio de influência cultural" (LOPES, 2009:29). Ao mesmo tempo em que era chamada de "Roma brasileira" - epíteto atribuído por D. Pedro II - devido à presença de inúmeras igrejas e irmandades e a forte influência religiosa na política local, a cidade, administrada por liberais, teve participação efetiva na Revolução Liberal de 1842 e promoveu a criação do Clube Republicano e da elaboração da Magna Convenção do Partido Republicano em 1873.

Respaldados pela Igreja ultramontana, os jesuítas adentraram a região como porta-vozes da oposição às mudanças políticas propostas pelo grupo dos liberais, condenando o ensino laico descolado da educação religiosa, como era o caso do Colégio Culto à Ciência de Campinas, inaugurado em $1874^{5}$.

Com um programa de endurecimento das ações do clero, da manutenção da vigilância e da expansão da rede de recristianização da sociedade, como "reforma" contra todo e qualquer ataque aos seus valores, o ultramontanismo colocava-se como uma reação ao avanço da política liberal e efetivava-se em uma barreira contra os ideais opostos aos da Igreja. A volta dos jesuítas como parte do programa do ultramontanismo e a entrada de diversas ordens religiosas europeias para recompor o quadro religioso

\footnotetext{
4 PETRONE, M. Thereza Schorer. A lavoura canavieira em São Paulo. Expansão e declínio. (1765-1851). São Paulo: Difusão Europeia do Livro, 1968:143.

${ }^{5}$ Ver Giovanna Ike Coan, em andamento.
} 
correspondiam ao propósito da Igreja de mitigar ou neutralizar as ações de irmandades voltadas ao catolicismo liberal.

Numa sequência de ações articuladas entre o Bispo de São Paulo e a Cúria Romana, oportunizaram-se condições para a vinda de padres capuchinhos, de Roma, para dirigirem o Seminário Episcopal de São Paulo, em 1855; para a abertura do colégio feminino Nossa Senhora do Patrocínio, das irmãs de São José de Chamberry, em Itu, em 1859; e para a criação do Colégio São Luís dos padres jesuítas italianos em 1867, uma das bases de restauração da Companhia de Jesus no Brasil.

A reinserção da Companhia não foi tranquila, pois o século XIX foi marcado pela síndrome antijesuítica, quando se atualizou a imagem negativa através de artigos, libelos, romances e exemplos da contundente campanha movida por centros republicanos e maçons contra a ordem, tida à época como uma "perigosa organização ultramontana destituída de qualquer sentimento nacional, sem qualquer interesse no serviço da nação" (Franco, 2000:164).

Na reabilitação da imagem da Companhia, os jesuítas promoveram o processo de reabilitação de José de Anchieta, como um "servo de Deus", e lançaram mão de estratégias que guiaram a ação de seus membros desde a fundação e garantiram sua continuidade. A disciplina e submissão, aliadas à ação: a criação de escolas, a organização e aplicação de sua metodologia de ensino nos mais diversos lugares e para diferentes culturas, as festividades e cerimônias e, principalmente, o uso da palavra, haja vista que, já no período colonial, os jesuítas assumiam que "A língua é o instrumento apto e próximo para a conquista das almas" (LEITE, 1932:72, tomo I) ${ }^{6}$.

Se de um lado a Companhia se firmava, de outro o Estado Republicano confirmava na Constituição de 1891 a laicização do ensino, o que provocou grande debate entre os partidários do ensino religioso e do ensino laico, bem como desencadeou uma luta também entre os protestantes e os católicos pelo domínio da educação.

\footnotetext{
${ }^{6}$ LEITE, Serafim. História da Companhia de Jesus no Brasil. Tomos I e II. Porto: Tipografia Porto Médico, 1938.
} 
Seguiram-se as Conferências Anchietanas no final do século para reafirmar a importância dos jesuítas na luta contra protestantes, na responsabilidade pela unidade do território nacional e na fusão e homogeneização de uma raça brasileira.

A missão civilizadora de Anchieta ganhava continuidade com a visita ao Colégio São Luís do Cardeal Arcoverde, o qual, como "púrpura cardinalícia"7, vinculava diretamente o Colégio (e a Igreja) ao poder romano, tal como previa o projeto ultramontano. Os discursos no evento Echo das Festas Collegiaes realizados pelas autoridades civis fazem parte da estratégia de legitimação dos jesuítas no período da primeira república.

Considerando a função persuasiva da voz e do gesto (ZUMTHOR,1993) no pronunciamento dos discursos, optamos por analisar a construção do texto para captar a voz jesuítica. Para isso, selecionamos como objeto de estudo a repetição de estruturas linguísticas (repetição de itens lexicais, estrutura sintagmática e frasal), por meio da tipificação e da identificação de funções da repetição, pois consideramos que a repetição de segmentos textuais idênticos não leva necessariamente à reiteração do significado ou da função do termo matriz.

Partindo do pressuposto de que "os jesuítas (...) acreditavam estar repetindo papeis anteriormente desempenhados seja por Cristo, seja pelos apóstolos ou pelos mártires" (VILAR, 1999:5) e que a sua escrita ecoa essas similitudes, assumimos a hipótese de uma correlação entre repetição de estruturas linguísticas e reiteração de tópicas. Dessa forma, o estudo da repetição poderá auxiliar no trabalho de desvendar o imaginário jesuítico e de desvendar as tópicas que aparecem nos diferentes textos. Nesse sentido, este trabalho procurará responder às questões: Qual o imaginário jesuítico que se pretendia fixar para os ouvintes? Que bens culturais, sociais e simbólicos os jesuítas procuram transmitir pela via educacional, com a criação do Colégio de S.

\footnotetext{
7 Expressão utilizada por Brasílio Machado em seu discurso de homenagem ao eminentíssimo senhor Cardeal D. Joaquim Arcoverde de Albuquerque Cavalcanti, em 1906.
} 
Luis, voltado para os filhos da elite ituense? Quais os meios linguísticos utilizados para a transmissão desses bens?

Considerando, por sua vez, que "Os jesuítas foram exercitados para a prática de uma "língua" una, homogênea" (VILAR, 1999:5)², optamos por selecionar uma questão gramatical para analisar se a padronização linguística adotada seguia o modelo do Português Europeu ou se atendia o modelo brasileiro de português culto. Para isso, daremos preferência ao estudo da colocação pronominal em contextos de orações finitas, infinitivas e grupos verbais, contextos que marcam claramente a diferença entre as duas variedades linguísticas (OLIVEIRA, 2011). A análise da colocação pronominal permitirá reponder às questões: Qual a gramática usada pelos jesuítas para atingir a elite ituense? Com quem os jesuítas se alinhavam?

Duas hipóteses se abrem a partir das considerações acima: a primeira, que toma como pressuposto que as práticas jesuíticas apostavam na repetição das Escrituras, incita a reflexão de que os jesuítas investiam no expediente da repetição linguística para a construção textual, como estratégia de configuração da teatralização vocal e gestual (ZUMTHOR, 1993); a segunda, a de que os jesuítas emulavam a gramática da elite econômica ituense, marcadamente republicana, para conquistá-la. Os republicanos usavam e abusavam da ênclise nas infinitivas preposicionadas (SILVA SANTOS, 2012; OLIVEIRA, 2014), o que encaminha para a hipótese de que os jesuítas adotavam a ênclise categórica (ou quase) para acompanhar a gramática da elite ituense.

Para responder às questões acima, fazemos a análise linguística dos discursos e panegíricos pronunciados em ocasiões festivas, a formatura dos bachareis do ginásio e a visita ao Colégio do primeiro cardeal brasileiro. Os textos são de autoria de personagens exponentes da política brasileira contemporânea e de jesuítas.

Analisamos também os jornais e revistas católicos e republicanos em circulação pela cidade procurando, na variedade de textos, resgatar o conjunto de ideias que

\footnotetext{
8 VILAR, Socorro de Fátima Pacífico. A invenção de uma escrita: Anchieta, os jesuítas e suas histórias. Tese de doutorado. FFLCH/USP,1999.
} 
circulavam naquele momento, bem como a variedade linguística ali contida. Assim, a análise linguística encontra-se no imbricamento de questões políticas, sociais e culturais, com o conjunto de ideias e de ações promovidas pela Companhia de Jesus na sua atividade educacional direcionada à elite paulista.

Dividimos a Introdução em duas partes: na primeira, trazemos a discussão sobre as articulações da linguística e das teorias sociais, procurando pontos de intersecção entre elas; na parte 2, descrevemos o material de análise, bem como a metodologia usada. No Capítulo I, tratamos da trajetória dos jesuítas desde a criação da Companhia de Jesus, a ação missionária e o trabalho na educação. No Capítulo II, abordamos aspectos históricos do Colégio São Luís e as conexões político-ideológicas travadas em Itu. No Capítulo III, fazemos uma análise das repetições presentes em textos do acervo antigo do Colégio a partir de textos que foram escritos na e para a instituição e constituíram um apanhado das ideias e práticas instituicionais. No Capítulo IV, apresentamos as discussões sobre sintaxe, mais especificamente sobre a colocação prononinal e os resultados das análises linguísticas. 


\section{PARTE 1 - Intersecções teóricas: traçando possibilidades de diálogos}

Em virtude do restabelecimento da Companhia de Jesus no Brasil e do trabalho educacional no interior de São Paulo, falar sobre o modelo jesuítico após a restauração é tema relevante não só para a compreensão do complexo contexto social vivenciado pelo grupo na transição da Monarquia para a República, mas dos caminhos que a língua portuguesa tomava naquele momento dada sua incisiva atuação na educação paulista. A pretensão deste trabalho não tem a amplidão exaustiva da descrição histórica. Ele procura adentrar a comunidade de prática ${ }^{9}$ e recuperar informações acerca dos primeiros anos do século XX, problematizando duas questões: a construção da fala jesuítica e a questão da variação linguística.

A referência feita, no título deste trabalho, à organização hierárquica e linguística já traz à pauta os dois caminhos que este trabalho percorre acerca da problematização sócio-histórica e da questão da identidade linguística do grupo. Nesse sentido, esta pesquisa é composta no imbricamento de campos teóricos, pois entendemos que a linguística é um campo amplo que tange outros e que falar de língua é falar de sociedade $^{10}$. A complexidade do tema que temos em mãos, no entanto, nos leva a calibrar a lente que guiará a observação do que estudamos.

Na delimitação dos campos, Chamber (1996) define dois caminhos possíveis para tratar língua e sociedade de acordo com o objetivo traçado pelo pesquisador:

"se o enfoque for o estudo das relações entre língua e sociedade com o objetivo de entender a estrutura da língua, a pesquisa se enquadra na área da sociolinguística. Se, por outro lado, o enfoque for o estudo da relação entre língua e sociedade com o objetivo de entender a estrutura da

\footnotetext{
${ }^{9}$ Tomamos neste trabalho o conceito de comunidade de prática de Eckert (2000) trazido por (CAMACHO, 2013:255), que o define como um "agregado de pessoas que se juntam para se engajar em algum empreendimento comum. (...) a comunidade de prática desenvolve meios para fazer coisas que se traduzem em práticas e essas práticas envolvem a construção de uma orientação compartilhada em relação ao mundo em volta.

${ }^{10}$ Note-se que a abordagem social é uma das possibilidades da linguística; não estamos, no entanto, nos esquecendo ou rejeitando qualquer outro tipo de abordagem.
} 
sociedade, a pesquisa se enquadra na área da sociologia da linguagem" (Chamber, 1996:10-11)

Nosso objeto de estudo, no entanto, parece não se enquadrar na dicotomia apontada por Chamber, pois contempla o sociolinguístico ao mesmo tempo que analisa aspectos da sociologia da linguagem. Abordamos aqui questões que nos parecem centrais para o desenvolvimento de nossa pesquisa, dado o recorte que fizemos: a noção de grupo social, de habitus, de capital simbólico e relacional ${ }^{11}$. Para discutir o objeto em $\mathrm{si}$, é preciso recorrer às teorias sociológicas na tentativa de uma compreensão mais ampla das questões linguísticas, pois acreditamos que a própria linguagem constitui um dos aspectos da experiência social dos sujeitos. Ao pensar na dimensão que pode tomar uma discussão que perpassa campos diferentes, surgem algumas perguntas: como enquadrar um trabalho que se apresenta para estudar o modelo linguístico de uma comunidade jesuítica? Como discutir em que grau os fatores externos da língua interagem com fatores internos promovendo a identidade do grupo?

É importante relembrar que a vertente da sociolinguística variacionista foi um salto para a maneira como a linguística vinha sendo abordada na primeira metade do século XX. Os estudos de Labov (1972,1974,1982,1994); e Weinreich, Labov e Herzog (1968) salientaram a análise dos padrões de comportamentos linguísticos observáveis dentro de comunidades de fala e evidenciaram conceitos que são, hoje, amplamente discutidos, como a definição do binômio variação e mudança como uma propriedade constitutiva da linguagem.

Nesse trabalho, abordamos a questão da variação linguística, colocando em evidência a noção de "comunidades de prática", pois consideramos que os jesuítas radicados em Itu, que produziam suas atividades educacionais e evangelizadoras no contexto da reafirmação da Igreja Católica nos primeiros anos da República, constituemse como um grupo social em interação com os demais grupos nas articulações de força

\footnotetext{
${ }^{11}$ Esses conceitos serão trabalhados ao longo dos capítulos.
} 
e de poder. Conceituações sociológicas, como a de "comunidade de prática, introduzem o tipo de abordagem que pretendemos fazer.

Assim dito, uma primeira discussão diz respeito aos fatores externos que agem na escolha das variedades linguísticas e que produzem o que é chamado de "prestígio" e "estigma". Na interação entre os grupos sociais, as variantes de prestígio colocam-se como instrumentos de poder e são consolidadas na forma não só de gramáticas escolares e guias de uso, mas também na fala e escrita de sujeitos de prestígio; seja em seus discursos públicos; seja em textos da imprensa, onde suas preferências linguísticas são colocadas como modelos de correção.

As concepções tão fortemente empregadas na linguística de variante de prestígio e estigmatizada são compartilhadas das teorias sociais. Elias \& Scotson (2000) mostram que estigma e prestígio são universais culturais e que é possível observar a atuação desses marcadores em diversas esferas da sociedade. Em seu trabalho sobre os "estabelecidos" e os "outsiders"12, os sociólogos descrevem o rótulo negativo que um grupo "estabelecido" firma em relação a outro, provocando instabilidade do equilíbrio de poder. O estigma é um atributo à imagem social de um grupo e estabelece-se como um instrumento de controle social. Assim, a discussão linguística que abrimos procura interpretar os posicionamentos e a disposição dos grupos na construção e manutenção de identidades na ordem social.

Nesse sentido, para produzir um tipo de análise que possa abarcar a posição de um grupo na configuração social, como é o caso do trabalho proposto aqui, recorremos mais uma vez à sociologia, na discussão trazida por Grendi (1998) sobre "grupos sociais". Esse conceito toma o lugar de outro largamente usado na metodologia de trabalho da sociolinguística variacionista, o de "classe social". Ao trazer a concepção de grupos, o exame de dados, comportamentos, solidariedades e estruturas de dependência, é colocado em evidência. $O$ autor argumenta em favor do estatuto de

\footnotetext{
${ }^{12}$ Nesse trabalho, os sociólogos trazem a análise de uma localidade, batizada ficticiamente de Winston Parva, na qual, a partir de entrevistas, documentos e uma análise etnográfica, retratam a lógica das configurações sociais e das relações de interdependência.
} 
grupos como um conceito essencial para a análise da estrutura social, que permite reconstruir a configuração social em qualquer uma de suas esferas.

Para a construção de uma teorização linguística que considere tais reflexões de natureza social, Eckert (2000) articula as concepções de redes/grupos sociais, identidades e variação linguística. Em seu trabalho que ficou conhecido como a "terceira onda da sociolinguística", a autora desenvolve fundamentos teóricos e uma análise variacionista das redes sociais. Ao incorporar para a sociolinguística o conceito de "comunidades de prática", colocou em evidência sujeitos engajados em suas atividades, que compartilham valores, formas de comportamento, opções estilísticas.

A concentração das relações sociais nas redes em um dado território concorre para o desenvolvimento do sentimento de pertença, da identidade local construída através da relativa homogeneidade de comportamento - no vestir, no falar, no divertir-se, no alimentar-se, nos valores praticados, entre outros, como assume o estudo da variação na linha das práticas sociais (ECKERT, 2000).

Por assim dizer, uma comunidade de prática é "um agregado de pessoas que se juntam para se engajar em algum empreendimento comum" (Camacho, 2010:255). O engajamento dos sujeitos desencadeia práticas compartilhadas e a "construção de uma orientação compartilhada em relação ao mundo em volta." Essa perspectiva linguística se articula com aquelas feitas pelo sociólogo francês, Bourdieu (1992) acerca do habitus, que se coloca como a capacidade de uma determinada estrutura social ser incorporada pelos agentes por meio de disposições destes para sentir, pensar e agir. As comunidades de prática são os espaços para a formatação do habitus ${ }^{13}$, nos quais os sujeitos manifestam determinados comportamentos, em um "sistema de disposições para a ação".

13 O conceito definido por Bourdieu (1992) destaca, no processo de socialização do indivíduo, um sistema de disposições que é, ao mesmo tempo, estruturado nos meios sociais, e é estruturante de ações e representações. 
Eckert designa que os estudos de "comunidades de prática", em que são observadas comunidades em pequena escala, "são capazes de fornecer informações mais detalhadas sobre o uso que os falantes fazem da variabilidade linguística". São essas unidades sociais menores que agem no processo de mudança. As comunidades de prática "evocam diferentes identidades" e "nas negociações dos indivíduos por status social, as formas linguísticas adquirem valor social, o que pode incrementar ou fazer regredir a mudança". A variável linguística passa a ser o lugar para a "construção do significado social da linguagem."

A partir do reconhecimento da relevância de se estudar as redes sociais e as comunidades de práticas, nosso desafio é analisar a identidade da comunidade jesuítica mostrando as forças que agem na língua para o incremento ou não da mudança. Como os grupos não são homogêneos, um outro conceito que se impõe é o de "biografia modal", pois os grupos são compostos por indivíduos com suas particularidades e especificidades e, estes indivíduos articulam-se de maneira variável entre os grupos. A "biografia modal", assim, consiste na "análise de indivíduos que expressam características do grupo social a que pertencem, indicando na prática o funcionamento das normas e regras estruturais existentes na sociedade"14. Dito isso, nosso trabalho apresenta a análise da escrita de sujeitos dispostos nos grupos, considerando que a identidade social

"é construída no próprio processo de articulação e de desenvolvimento dos indivíduos com as comunidades de práticas de que participam e a identidade de cada comunidade depende do processo de engajamento e de envolvimento dos participantes. O grau de envolvimento depende do grau em que os indivíduos adquirem o repertório da comunidade de prática, assimilam o objetivo do empreendimento compartilhado e estabelecem padrões de relacionamento com os outros participantes envolvidos." (Eckert, 2000)

\footnotetext{
${ }^{14} \mathrm{O}$ conceito foi usado pelo autor no seguinte artigo: LEVI, Giovanni. Les usages de la biographie. Annales ESC, n. 6,
} 1989 , p. $1.325-36$ 
Em relação às identidades pessoais, Eckert ainda designa que a prática estilística é a chave de todo processo de variação. O estilo é visto como um "ajuste" dos falantes à situação mediante o emprego de variáveis individuais. Além disso, os falantes combinam variáveis na intenção de criar modos diferenciados de fala, o que Ihes atribui uma identidade pessoal. Paradoxalmente, a identidade pessoal localiza o falante na ordem social.

A micro-história vem trabalhando com a questão da identidade pessoal ao mostrar que os pesquisadores devem retomar a linguagem dos atores que estuda, no intuito de construir as identidades sociais que se articulam por meio de uma rede complexa de relações. Dessa forma, procuramos discutir as redes de relações na análise linguística do grupo de jesuítas com os demais grupos, mostrando o comportamento dos indivíduos na tentativa de compreender a identidade do grupo e suas redes relacionais.

Em relação à discussão dos grupos, cabe ainda salientar o papel do espaço escolar no qual atua o grupo de religiosos jesuítas. Ao discutir o conceito de habitus, Bourdieu faz emergir a reflexão crítica sobre o papel da escola na reprodução social. $O$ contexto escolar é lugar da transmissão do capital cultural, onde se legitimam os saberes e conhecimentos que são reconhecidos socialmente. $O$ espaço social é um espaço de lutas e, nesse sentido, a educação e a cultura exercem a legitimação de um grupo sobre o outro. O capital simbólico confere o prestígio ou honra e que permite identificar os agentes no espaço social.

Ao longo da pesquisa, procuramos articular essas concepções que nos parecem centrais para as demais discussões a serem feitas. Destacamos alguns conceitos e procuramos articular as concepções ao longo do trabalho. Acreditamos deixar evidenciado o caráter interdisciplinar que esta pesquisa tomou na tentativa de compreender o fenômeno linguístico no emaranhado das tramas sociais. 


\section{PARTE 2 - Acervos: memória, identidade e história do português paulista}

A seguir, são apresentadas as duas bases de dados que compuseram este trabalho: o acervo antigo do Colégio São Luís, em São Paulo; e o acervo da Biblioteca Histórica da Igreja do Bom Jesus, em Itu. É importante considerar que uma parcela das fontes pesquisadas encaminhou o entendimento da própria constituição histórica e identitária do nosso objeto de análise; a outra, além desse expediente, proporcionou a composição do corpus de análise linguística.

\section{Acervo antigo do Colégio São Luís}

Entramos no acervo antigo do Colégio jesuítico São Luís, a fim de escavá-lo, no intuito de compreender a construção da memória e da identidade da instituição. Essa imersão forneceu pistas acerca do conjunto de ideias que envolve a existência da instituição e a circulação dos saberes.

A constituição do acervo bibliográfico dá início à produção da história do Colégio, construindo um passado para suas personagens e criando uma identidade para a instituição. Datada de 1867, ano de fundação do Colégio São Luís, em Itu ${ }^{15}$, o acervo teve um montante inicial de 25.000 volumes (ANEAS, 1935, p.82 apud SCHIMIDT, mimeo) proveniente de doações. O registro de sua história foi uma preocupação que se estabelecia como uma das primeiras diretrizes do Colégio, como declara Tristão Mariano da Costa, compositor e um dos primeiros professores do Colégio São Luís, em sua Breve Notícia Histórica do Colégio São Luís, escrita entre os anos de 1905 e 1906.

Nunca é demais escrever-se para repetir e conservar na memória dos homens os atos dos grandes benfeitores da humanidade. Suas obras, muitas das vezes no principio, tão pequenas debaixo das vistas humanas, e tão grandes no conceito de Deus, que vemos muitas vezes brotar de um

\footnotetext{
${ }^{15} \mathrm{Em} 1918$, o acervo foi transferido para as novas instalações do Colégio São Luís, na cidade de São Paulo. O prédio em Itu, que hoje é ocupado pela unidade militar do Exército Brasileiro - 2ㅇ Grupo de Artilharia Montada, conserva apenas algumas poucas fotos da memória do Colégio pregadas na parede do estabelecimento.
} 
rochedo esteril fontes d'agua viva, assombrando o mundo e fazendo pasmar aqueles que as contemplam. (COSTA, 1906:1)

O acervo antigo ${ }^{16}$ ficou durante um longo período fragmentado e distribuído em diversas bibliotecas jesuíticas, entre elas a Biblioteca da Faculdade, a Biblioteca da Comunidade e a Biblioteca do Pateo do Collegio. Por essa razão, muitas das obras pertencentes ao Colégio ainda não estão cadastradas ou listadas, o que dificulta o acesso.

Embora a constituição do acervo antigo seja uma prioridade do Colégio, isso não limita a forte pressão da Cúria para a unificação das bibliotecas da Igreja e do Colégio em um só espaço físico. Essa é uma discussão interna entre clérigos, historiadores e bibliotecários, pois a centralização do acervo colocaria em risco a memória da educação paulista.

O acervo ${ }^{17}$ conserva documentos referentes às primeiras décadas de atuação da instituição no interior paulista. $O$ inventário ${ }^{18}$ produzido por Schimidt (s.d.) lista livros, atas, diários, anuários, missais, cartas, jornais, revistas, placas comemorativas e iconografia. Tanto os documentos produzidos na instituição, quanto aqueles utilizados nas atividades escolares, narram episódios da história do Colégio e da sociedade que auxiliam no resgate da memória histórica.

Após um exame prévio do material disponibilizado, selecionamos os documentos para a formação do corpus, seguindo critérios que nos ajudariam a compor um perfil linguístico dos sujeitos envolvidos com a instituição na época delimitada para análise. É evidente que toda seleção de documento histórico é apenas uma possibilidade de olhar sobre o passado. Há que se considerar que a organização do acervo, a seleção dos

\footnotetext{
${ }^{16}$ No período de consulta ao acervo (2013/2014), ocorria a reorganização das obras, catalogação e limpeza. 0 tratamento técnico de higienização e restauro era realizado em uma sala destinada a isso no próprio prédio do Colégio. A entrada é restrita a funcionários e a visita de pesquisadores externos à comunidade jesuítica é feita mediante autorização da direção da instituição, que avalia a possibilidade de atendimento aos interessados.

${ }^{17}$ A obra mais antiga do acervo é uma Bíblia em latim datada de 1539.

${ }^{18}$ SCHIMIDT, Gladis Maria. Inventário comentado do acervo antigo da biblioteca do Colégio jesuíta São Luís, São Paulo. (mimeo).
} 
documentos que deveriam ser preservados, a forma como foram conservados e a disposição do material para consulta relatam mais da tentativa de composição desse passado do que do passado em si. Além disso, há o fato de o nosso trabalho apresentar uma delimitação de olhar, condição inerente à pesquisa histórica, que se orienta para a construção e organização linguística, uma vez que tomamos como objeto de estudo uma questão gramatical e uma questão de estruturação textual. Dito isso, explicitamos os critérios adotados para a seleção dos documentos, a descrição e a conjuntura em que foram produzidos.

O primeiro critério que adotamos para a seleção do material foi a língua na qual o documento foi escrito. A importância desse critério se dá pelo fato de muitos textos terem sido escritos em italiano, língua materna dos padres fundadores do Colégio; ou em latim, a língua oficial da Igreja. Como nosso foco é o estudo da língua portuguesa, restringimos a procura de fontes escritas em português.

O segundo critério adotado foi o da delimitação do período histórico para a coleta do material. Levando em consideração a data da fundação do Colégio, 1867, a "questão religiosa" que envolvia restrições à atuação de jesuítas no Brasil, o fim do regime de padroado e o movimento ultramontano que implementou a vinda da Europa de diferentes ordens religiosas, tomamos como balizas a data da abertura do Colégio até a primeira década do século $X X$.

Foram acessados os seguintes documentos:

- Discursos pronunciados nos actos da Collação de Grau aos Bacharelados em Sciencias e Letras no Collegio S. Luiz em Ytu de 1904 até 1910.

- Echo das Festas Collegiaes em honra a S. Luis Gonzaga e homenagem ao eminentíssimo senhor Cardeal D. Joaquim Arcoverde de Albuquerque Cavalcanti/ CSL/1906; Discurso Dr. Brasilio Machado na Sessão Solemne do CSL em homenagem ao eminentíssimo Senhor Cardeal D. Joaquim Arcoverde de Albuquerque Cavalcanti - 2 de julho de 1906; Panegíricos - 
Arcipreste Ezechias Galvão de Fontoura; Monsenhor Antonio de Macedo Costa; Pe. André Fialho; 1906

- Programma de ensino para os colégios da Cia. de Jesus, 1864 e Publicidade CSL, s/d

- Discursos da Arcadia Gregoriana, 1882-1884

- Breve Histórico do Colégio São Luís - F. Pedreira de Castro S.J.,1953

- Breve Notícia Histórica do Colégio São Luís - Maestro Tristão Mariano da Costa, 1905/1906

- Lembrança do $25^{\circ}$ aniversário do Collégio - 1892

- Narrações das Festas de Nossa Senhora 1879-1917

- Periódico O Collegio Anno V - N68 - 1914

- Solemne Distribuição de Prêmios 1917

- Relação dos alumnos matriculados 1867 até 1892

- Colégio São Luís - Matrícula dos Alumnos 1917-1933

- Livro das Actas das Sessões do Senado da 1a.Divisão: no ano de 1903

- Selecta Nacional - Curso Pratico de Litteratura Portugueza - Primeira Parte, por F. Julio Caldas Aulete, Seleção de textos: parabolas, apologos, anedoctas, contos, breves narrações, descripções, typos nacionais, paralelos, caracteres e retratos, pensamentos e sentenças, provérbios e rifões, historia e biografia; religião, filosofia, moral e sciencia; papeis officiaes; cartas, estylo bíblico; estylo gongórico, 1887, Lisboa.

- Selecta Nacional - Curso Pratico de Litteratura Portugueza - Segunda Parte, por F. Julio Caldas Aulete/Professor do Lyceu de Lisboa e deputado ás côrtes em diferentes legislaturas, etc./Approvada pelo Governo para uso dos lyceus, e por ele mandada adoptar em 1885 como livro de leitura e análise nas aulas primarias - Introducção/ Preceitos Geraes da Rhetorica.

- Reflexões sobre a Lingua Portugueza, escriptas por Francisco José Freire, publicadas com algumas anotações pela Sociedade Propagadora dos Conhecimentos Uteis - Trata do valor das palavras e correcção da 
Gramatica. Segunda edição, Lisboa, Typographia do Panorama, Travessa da Victoria, 73, 1863

- Questões Língua Portugueza por F. Adolpho Coelho, Segunda Parte, Livraria Internacional: Porto, 1874

O conjunto dessas obras pode ser dividido em três categorias. Primeiramente as obras correspondentes ao registro da rotina escolar, como a relação de alunos matriculados, as solenes distribuições de prêmios, os periódicos. São registros que reconstroem a história da instituição, dando indícios das atividades elaboradas cotidianamente no Colégio por alunos e professores. O segundo tipo refere-se às práticas docentes, como o programa de ensino e os livros utilizados nas aulas: cursos práticos das aulas de literatura portuguesa, gramática e retórica. Em sua maior parte, são materiais que não foram produzidos pela instituição, livros didáticos ou descrições da organização dos $\operatorname{cursos}^{19}$. A terceira categoria são os textos produzidos para as cerimônias e pronunciados em eventos festivos do Colégio. Esses documentos foram impressos como estratégia para a construção da memória da instituição.

Todo o material consultado reconstrói o chamado "clima de opinião"20, trazendo dados sobre os eventos realizados no Colégio e compondo o universo das práticas e ideias em circulação no período. Duas obras se sobressaem para a análise que propomos dos componentes sociais e linguísticos: o livro Discurso pronunciado no acto da collação de gráu aos bacharelandos em sciencias e lettras no Collegio S. Luiz em Ytu, que apresenta seis discursos datados entre 1904 e 1910, eventos estes realizados na presença de representantes do governo do Estado e delegados Fiscais do governo Federal; e o Echo das Festas Collegiaes em honra a S. Luis Gonzaga e homenagem ao eminentíssimo senhor Cardeal D. Joaquim Arcoverde de Albuquerque Cavalcanti, de

\footnotetext{
${ }^{19}$ Corresponde aos itens 3, 15,16 e 17 elencados acima.

20 Termo emprestado da Historiografia que corresponde, segundo Koerner (1996), dentro do princípio de contextualização, ao "espírito da época", à observação das correntes intelectuais do período e da situação socioeconômica, política e cultural.
} 
1906, cujo convite para o pronunciamento partiu do reitor do Colégio, como atesta o panegírico pregado pelo Arcipreste Ezechias Galvão de Fontoura:

Convidado pelo illustrado e zelosor reitor deste estabelecimento para fazer o panegyrico de S; Luiz, por occasião da vsita do Eminentissimo Principe da Santa Egreja Romana, necessita de expandir minha alegria, saudando primeiramente S. Eminencia Revma, em nome do fidelissimo povo ytuano e deste Collegio. (Arcipreste FONTOURA)

As duas obras referem-se à produção escrita em português das elocuções feitas no curso da primeira década do século XX nas festividades do Colégio as quais foram guardadas como constitutivas da memória da instituição.

A obra entitulada Discurso pronunciado no acto da collação de gráu aos bacharelandos em sciencias e lettras no Collegio S. Luiz em Ytu, foi impressa pela Typographia Brazil de Carlos Gerke \& Cia. e, ao que deixa transparecer, sofreu encadernação posterior. Há apenas uma cópia desse livro no acervo do Colégio, destinado à consulta interna. Cada um dos seis discursos apresenta imagens em art nouveau e sua encadernação considerou a cronologia de pronunciamento.

Organizados e editados em formato livro, esse conjunto de seis discursos apaga ou minimiza o contexto no e para o qual foi produzido - a colação de grau de formandos do ginásio - e ganha estatuto diferente com o novo material de circulação. O seu papel passa a ser "objeto de formulações teóricas ${ }^{21 "}$ ", no sentido de que a organização do conjunto de textos em um livro encerra um conjunto de saberes que o organizador considera importante para a permanência e a dominância de um feixe de ideologias que permeia as práticas jesuíticas. Acrescente-se que o livro não tem uma apresentação ou introdução e não traz a indicação do nome do seu organizador. Essa impessoalização Ihe dá um caráter providencial quanto mais que o conjunto de textos aí reunidos pertence aos oradores leigos. Em outras palavras, o livro não traz a mão dos jesuítas, os quais

${ }^{21}$ ISER, W., apud HANSEN, J., 1995:91 
entram na configuração apenas como "participassivos"22", estratégia conveniente para alargar e solidificar a legitimação de suas práticas. O livro é composto de seis textos, na seguinte ordem:

1. PORChAT, Dr. Reynaldo. (1904) Discurso Pronunciado no acto da Collação de Gráu aos Bacharelandos em Sciencias e Lettras no Collegio S. Luiz em Ytú

2. ARANTES, Dr. Altino. (1906) Discurso pronunciado no acto da collação de gráo aos Bacharelandos em Sciencias e Lettras no Collegio de São Luiz de Ytú

3. LAET, Dr. Carlos de. (1907) Discurso que como paranympho dos Bachareis em Sciencias e Letras pelo Collegio São Luiz, em Itú

4. ALMEIDA JUNIOR, Dr. João Mendes de (1908) Discurso que como paranympho dos Bachareis em Sciencias e Lettras pelo Collegio de S. Luiz em Itú

5. CAMARA LEAL, Dr. Eusebio L. Vaz. (1909) Discurso como paranympho dos bachareis em sciencias e letras pelo Collegio São Luís, em Ytú

6. PRESTES, Dr. Julio. (1910) Discurso Proferido no Collegio de S. Luiz, em Ytú na collação de gráo aos bachareis em sciencias e letras

Os discursos foram envoltos com uma capa interna em que se apresentava o orador e o evento no qual o discurso havia sido proferido. Na figura abaixo, a capa do discurso de Reynaldo Porchat, "lente cathedratico da Faculdade de Direito de S.Paulo", pronunciado por ocasião da colação de grau dos bacharelandos em "sciencias e lettras no Collegio S. Luiz em Ytú", no dia 4 de dezembro de 1904:

\footnotetext{
${ }^{22}$ Agradeço à profa. Marilza de Oliveira por ter se lembrado do neologismo criado pelo escritor moçambicano Mia Couto, que contempla a ideia de uma participação não-direta na elaboração dos documentos.
} 


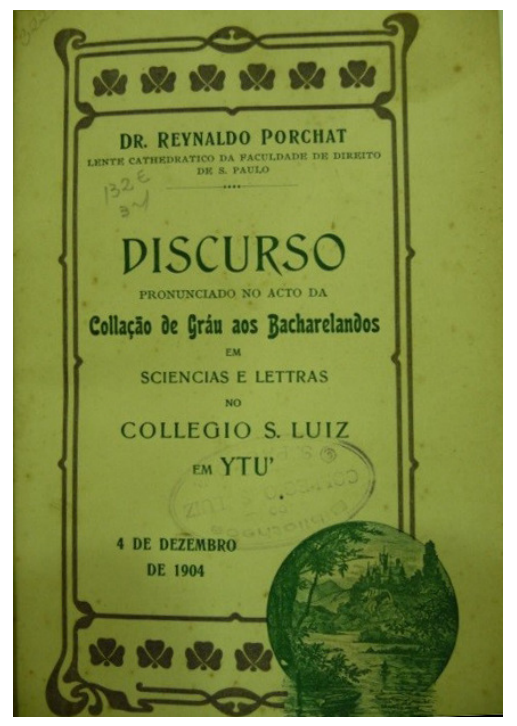

Figura 1 - Discurso pronunciado no acto da Collação de Gráu aos Bacharelandos em Sciencias e Lettras no Collegio S. Luiz em Ytú - Dr. Reynaldo Porchat

A escolha dos oradores não parece ter sido aleatória, antes, pretende evidenciar a articulação do colégio jesuítico com a esfera estatal, no sentido de formalizar o compromisso com a educação e a prestação de serviços à sociedade. Outra relação revelada é com a Academia de Direito do Largo São Francisco, que se coloca naquele momento como um dos centros irradiadores dos ideais católicos na sociedade. Uma rápida incursão na biografia dos oradores mostra a presença maciça dos bachareis em direito:

1. Dr. Reynaldo Porchat (Santos, 23 de maio de 1868 - São Paulo, 12 de outubro de 1953), que estudou na Academia de Direito do Largo São Francisco entre os anos de 1888 e 1891. Era lente catedrático da Academia de Direito de São Paulo naquela ocasião.

2. Dr. Altino Arantes Marques (Batatais, 29 de setembro de 1876 - São Paulo, 5 de julho de 1965), formado pela Academia de Direito do Largo São Francisco em 1895. À época do discurso, exercia o cargo de deputado federal. 
3. Dr. Carlos Maximiliano Pimenta de Laet (Rio de Janeiro, 3 de outubro de 1847 - Rio de Janeiro, 7 de dezembro de 1927), formou-se em engenharia pela Faculdade Politécnica do Rio de Janeiro, mas exerceu a profissão de professor e diretor de Internato Pedro II, Externato de São Bento e Seminário de São José.

4. Dr. João Mendes de Almeida Junior (São Paulo, 30 de março de 1856 - Rio de Janeiro, 25 de fevereiro de 1923), que se formou pela Academia de Direito do Largo São Francisco em 1877. Professor da Academia de Direito à época.

5. Dr. Eusébio Innocencio Vaz Lobo da Camara Leal (Curitiba, 28 de julho de 1857 - Taubaté, 20 de julho de 1932), formou-se pela Academia de Direito do Largo São Francisco em 1879. Era pai de um formando.

6. Dr. Julio Prestes de Albuquerque (Itapetininga, 15 de março de 1882 — São Paulo, 9 de fevereiro de 1946), formou-se pela Academia de Direito do Largo São Francisco em 1906. Em 1910, era deputado estadual de São Paulo. Havia ocupado o cargo de fiscal do curso ginasial e fiscalizado o Colégio.

Dos seis oradores, cinco formaram-se na Academia de Direito do Largo São Francisco, sendo que dois exerciam funções de professores da Instituição, Dr. João Mendes e Dr. Reynaldo Porchat. Azzi (2005) mostra a atuação desses oradores dentro da Academia como lideranças católicas, defensores da instituição católica na sociedade, com o objetivo de propagar a fé e os valores cristãos no projeto de constituição de uma base para a formação social brasileira, procurando sanar os males da República advindos da laicização da educação. Da persepctiva do capital relacional23, a análise de cada um dos oradores se inclui na compreensão do sentimento de pertinência e de

\footnotetext{
${ }^{23} \mathrm{O}$ capital relacional se refere ao conjunto de relações que um indivíduo ou grupo de indivíduos mantém com outros, objetivando assegurar determinados ganhos.
} 
cooperação dos indivíduos que compartilham as mesmas ideias, as alianças estratégicas no imbricado funcionamento das estruturas.

Um dos oradores - Carlos de Laet - exercia a função de diretor do Colégio Pedro II, do Rio de Janeiro. A escolha desse orador concatena-se a uma outra esfera de relações, aquelas estabelecidas entre as instituições de ensino brasileiras de elite. Soma-se a isso a simbologia presente na relação com o Rio de Janeiro, cidade em que Laet cursou a Escola Politécnica. A Capital Federal a esse tempo mimetizava a modernidade das construções e ventilava o ideário de cidade cosmopolita. Uma conexão com uma personagem envolvida no processo de modernização da Capital Federal conferia prestígio ao Colégio.

Um dado não menos importante é presença do Dr. Julio Prestes de Albuquerque que, pela sua função de fiscal da educação, fora convidado para legitimar as práticas educacionais do Colégio e todo seu conjunto de valores, frente à educação do Estado. Por fim, há o discurso do Dr. Eusébio Innocencio Vaz Lobo da Camara Leal, advogado, que, tendo exercido cargos públicos ${ }^{24}$ durante a Monarquia, com o fim do regime, dedicou-se à educação e à advocacia. $\mathrm{O}$ dado mais relevante a respeito dessa figura é o fato de que seu filho era um dos formandos da turma para a qual Leal fora convidado para ser orador na colação de grau, conforme aponta ele mesmo em seu discurso:

Calculei, desde logo, a emoção que havia de apoderar-se de mim, neste momento, por vêr no meio de vós, entre os laureados do dia, um filho dilecto,que tem sabido corresponder aos esforços paternos para Ihe dar uma solida instrucção e uma educação aprimorada. (LEAL)

A informação ao auditório, em primeira pessoa, de que tinha um filho no grupo de formandos de um Colégio que primava pela "solida instrucção e uma educação aprimorada", além de ter um peso testemunhal, tinha a função de legitimar as atividades

\footnotetext{
${ }^{24}$ Foi nomeado promotor público em Jundiaí, em 1880; e, em 1881, foi removido para a comarca de Taubaté onde manteve-se até 1886.
} 
jesuíticas, uma vez que Leal tradicionalmente tinha sólidos vínculos com a extração política.

Considerando as cerimônias para as quais esses discursos foram criados, ficam evidenciadas as intenções do colégio jesuítico na construção de uma imagem de poder e solidez junto à sociedade. As festividades oportunizam a reafirmação social e a resignificação da Companhia de Jesus junto ao meio, pois, segundo os oradores, a educação católica é a única a trazer os alicerces verdadeiros de que a sociedade precisa, quando a sociedade está perdida nas mentiras e falsidades das novas teorias. A escolha dos oradores para tais eventos estabelece-se como uma estratégia de afirmação do poder da Igreja e do grupo jesuítico, resguardando um lugar na hierarquia social.

A segunda obra selecionada para a análise linguística e sócio-histórica: Echo das Festas Collegiaes em honra a S. Luis Gonzaga e homenagem ao eminentíssimo senhor Cardeal D. Joaquim Arcoverde de Albuquerque Cavalcanti traz a compilação de textos referentes à semana de festividades realizada em junho/julho de 1906, em honra a S. Luiz Gonzaga, patrono da escola, e em homenagem ao visitante, o recém nomeado Cardeal D. Joaquim Arcoverde de Albuquerque Cavalcanti. Esse conjunto de textos é constituído de um relato das atividades produzidas durante a semana, escrita por um padre convidado; de um discurso proferido na sessão solene em homenagem ao Cardeal e de um discurso proferido na sessão solene em homenagem ao Cardeal.

Há três cópias no acervo interno do Colégio São Luís e mais uma cópia de circulação externa no acervo da Biblioteca Pe. Antônio Vieira - Pateo do Collegio. Os volumes foram encadernados pela gráfica Duprat \& Cia no ano correspondente à festividade. Ao contrário da obra que compila os discursos de leigos, essa obra que traz os discursos de religiosos, ao ser encadernada, recebeu um título - Echo das Festas Collegiaes, sinalizando a vontade da permanência da conjuntura que the deu origem, não tanto a colação de grau, mas a visita do primeiro cardeal da América Latina, ocorrida no ensejo das festas colegiais. Nesse sentido, o echo da festas collegiaes é o próprio príncipe da igreja católica cuja nomeada vinha na sequência da Questão religiosa. 
A capa da encadernação da brochura traz o título da obra e a contracapa apresenta a fotografia do cardeal Arcoverde em pose regencial. Sentado em um trono, apoia os pés sobre uma almofada vermelha, sinalizando a sua hierarquia em relação aos homens que tem contato direto com a terra; os braços apoiados no braço do trono - lidos metonimicamente - representam o domínio sobre o próprio trono:
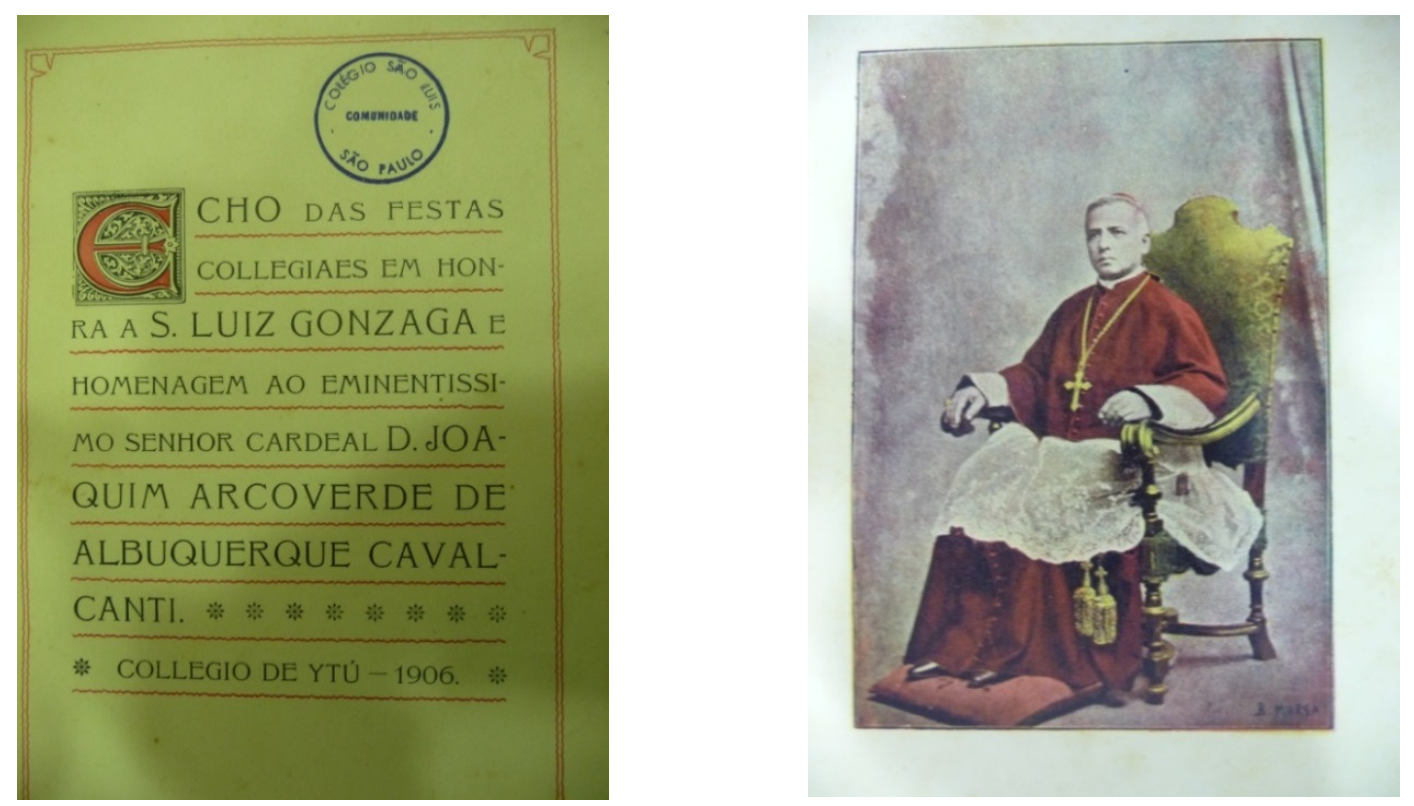

Figura 2 - Capa e Contracapa da Encadernação do Echo das festas collegiaes em honra a S.Luiz

Gonzaga e

Homenagem ao eminentissimo senhor cardeal

D. Joaquim Arcoverde de Albuquerque Cavalcanti

Collegio de Ytú - 1906

No que concerne à organização dos textos, aqui também se verifica uma diferença acentuada entre as duas obras em análise. O livro Echo das Festas Collegiaes, embora não traga o nome do seu organizador, inicia-se com um relato escrito por um padre que se descreve como convidado da instituição jesuítica para tal feito. 
A narrativa, assinada apenas com as iniciais de seu nome, S.P.L ${ }^{25}$., descreve o início das festividades na noite de 29 de junho de 1906 em honra ao convidado especial o Eminentíssimo Senhor Cardeal D. Joaquim Arcoverde de Albuquerque Cavalcanti:

A presença de um Principe da Egreja revestiu de magestosa pompa a solemnidade em honra do angelico Padroeiro da mocidade estudiosa, e assignalou-a como um acontecimento religiosa de summa importancia nos fastos d'aquelle Gymnasio. (S.P.L.)

O relato de abertura do livro das Festas Collegiaes coloca-se como uma resenha geral da semana de festividades desde a chegada do Cardeal à cidade, seu recebimento pelo reitor do Colégio, o padre Manoel Gabinio de Carvalho S.J., destacando os discursos proferidos pelos oradores na abertura da "sessão litteraria" do evento, os quais não constam da edição e, ainda, relacionando os nomes das autoridades civis, municipais e eclesiásticas presentes:

Repleto de collegiaes, de muitas familias, de pessoas qualificadas e de populares, compareceu ás $101 / 20$ Eminentissimo Senhor Cardeal trajando capa magna, precedendo o gentil-homem de sua côrte, cavalheiro Virginio Marcondes Pereira; padre J. Rezende, vigario do Braz; mestre de ceremonias, conego Luiz Gonzaga do Carmo; monsenhores João Alves Coelho Guimarães e Dr. Benedicto de Souza, vigario de Santa Cecilia; arcipreste conego Ezechias Galvão de Fontoura e conego dr. João Evangelista Pereira Barros, vigario de Santa Iphigenia. Servia de caudatario, vestindo batina rôxa, o alumno Antonio Baptista de Carvalho. (S.P.L.)

A descrição segue detalhando a ornamentação da cidade, o programa das festividades, as homenagens, as preces, os coros e hinos. Finaliza atestando o seu desvanecimento e sinceridade pela participação no evento.

\footnotetext{
${ }^{25}$ Não conseguimos identificar o nome do padre a partir de suas iniciais.
} 
Logo após o relato de 14 páginas, datado de 4 de julho de 1906, segue o discurso proferido pelo Dr. Brasilio Machado na sessão solene do evento, que tem como tema a nomeação de Arcoverde como o primeio Cardeal da América Latina. Na sequência, os três panegíricos proferidos por padres. Os quatro documentos que também compõem o corpus trazem as datas em que foram pronunciados:

7. MACHADO, Dr. Brasilio (2 de julho de 1906) Discurso proferido em Ytú pelo Dr. Brasilio Machado na sessão solemne do Collegio S. Luiz em homenagem ao eminentissimo senhor cardeal D. Joaquim Arcoverde de Albuquerque Cavalcanti.

8. FIALHO S.J., Pe André. (30 de junho de 1906) Panegyrico de S. Luiz Gonzaga pregado em Ytú.

9. MACEDO COSTA, Monsenhor Antonio de. (1ํ de julho de 1906) Panegyrico de S. Luiz Gonzaga pregado em Ytú.

10. FONTOURA. Arcipreste Ezechias Galvão de. (1ำ de julho de 1906) Panegyrico de S. Luiz Gonzaga pregado em Ytú.

O discurso do Dr. Brasilio Machado, conselheiro da Instrução Pública de São Paulo, é o segundo texto encadernado na brochura, trazendo as referências emolduradas na capa interna: 


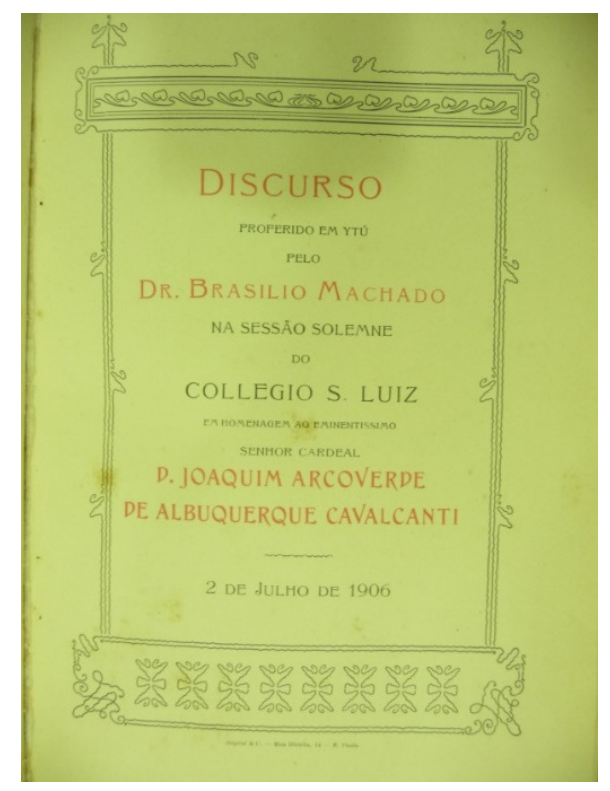

Figura 3 - Capa interna do Discurso proferido em Ytú pelo Dr. Brasilio Machado na sessão solemne do Collegio S.Luiz 2 de Julho de 1906

O orador destaca a figura do cardeal como ex-professor do Colégio São Luís e examina que, ao ocupar uma alta posição na hierarquia da Igreja, o Cardeal trará maior zelo ao catolicismo no Brasil, em tempos de ateísmo prático, materialismo, cientificismo. Assinala a importância da presença de pessoa tão ilustre e próxima no Colégio, capaz de estabelecer conexão direta com as altas esferas de poder eclesiásticas, no intuito de proteger a Igreja no Brasil e, a exemplo de Anchieta, ser um continuador de sua missão civilizadora.

A parte final da encadernação é constituída da coletânea de brochuras dos panegíricos pregados durante as festividades. Abaixo, a capa do panegírico pregado pelo Padre André Fialho S.J., em que constam o título, a data, o local e o nome do orador, informações que aparecem dentro de uma moldura com menos ornamentos do que aquela que encerra o discurso de Brasílio Machado: 


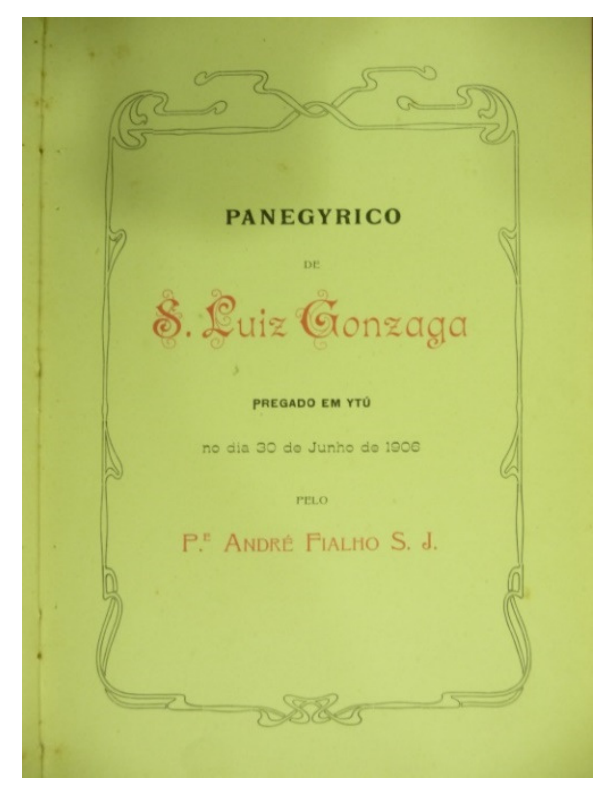

Figura 4 - Capa interna do Panegyrico de S. Luiz Gonzaga pregado em Ytú no dia 30 de Junho de 1906 pelo Pe. André Fialho S.J.

Os panegíricos, que fazem parte do "topos do sobrepujamento" (CURTIUS:1979), enumeram as virtudes de um santo, tomado como exemplo. Nos três panegíricos pregados nas festividades de 1906, salienta-se a importância da religião frente aos perigos do mundo moderno e toma-se o exemplo de São Luís de Gonzaga como modelo que os jovens moços devem seguir.

É emblemático que os panegíricos e os dicursos compilados em livro sejam do mesmo período: os panegíricos e o discurso em homenagem ao Cardeal Arcoverde são datados de 1906; os discursos dos paraninfos proferidos na colação de grau dos bacharelandos ${ }^{26}$ do Colégio se distribuem nos primeiros anos do novo século: 1904 , 1906, 1907, 1908, 1909 e 1910. Para entender a contingência sócio-histórica desses documentos faz-se necessário retroagir no tempo para detectar as instâncias de sua produção e de sua transmissão.

\footnotetext{
${ }^{26}$ Em relação ao termo "bacharelando", note-se que se trata da finalização dos estudos que antecedem a entrada nos cursos superiores.
} 
Retrocedendo de uma década, os documentos do Colégio se circunscrevem ao evento comemorativo do terceiro centenário da morte do Padre Anchieta (1897). O evento consistiu em uma série de palestras em que figuras proeminentes do meio eclesiástico e do meio acadêmico, notadamente da Academia de Direito, proferiram leituras públicas entre 1896 e 1897, na Catedral da Sé; e, em seguida, na biblioteca da referida Academia. Promovidas por Eduardo da Silva Prado, o conjunto de "Conferências Anchietanas ${ }^{27}$, , publicado apenas em $1900^{28}$, foi projetado como resposta à instabilidade social, exponenciada pela radicalização do jacobinismo, e à intricada política do novo regime de governo bem como o fim do padroado.

Ainda que não atacassem diretamente a nova forma de governo, os palestrantes partidários do regime destituído se instrumentalizaram da perspectiva apologética do padre Anchieta, e por extensão da Companhia de Jesus, visando a resgatar o imaginário de tradição e de estabilidade do Império. É nesse contexto que a figura de Anchieta é recuperada pelos oradores leigos nos eventos de formatura dos alunos do Colégio São Luís, como mostram os trechos abaixo:

... organisados nessa admiravel Companhia, que, vendo realizar-se a previsão do seu grande fundador, vai vivendo sempre e sempre se expandindo [...] vê desenhar-se, entre as nevoas que envolvem o alvorecer da pittoresca Pyratininga, a figura sympathica do padre jesuita, na personagem excelsa de José de Anchieta, portadora de paz e tranquilidade aos incolas da terra querida (PORCHAT).

É de vel-os, então, nos mil desdobramentos da vida!

Anchieta tanto surge, evocador e nostalgico, a bordar de poesias 0 abamado de nossas praias, com vem - capitão em conquista - luctando

\footnotetext{
${ }^{27}$ Foram publicados nove textos: três do clero paulista (o Arcediago Francisco de Paula Rodrigues, o padre jesuíta Américo de Novais e o cônego Manoel Vicente da Silva), um proveniente da escola politécnica do Rio de Janeiro (Teodoro Sampaio) e cinco bacharéis em Direito (Eduardo da Silva Prado, Joaquim Nabuco, Brasílio Machado, João Pereira Monteiro e Couto de Magalhães).

${ }^{28} \mathrm{O}$ atraso na publicação dos documentos se justifica pela perseguição aos monarquistas promovida pelo jacobinismo.
} 
contra os homens e contra os elementos, transpondo as serras azues e as mattas verdes e investindo contra perigos sem nome, semear a palavra de Christo, amanhar a terra e fundar São Paulo, como se plantasse um viveiro de almas predestinadas a transportar o progresso por todos os recantos do Brasi (J. PRESTES).

As Conferências Anchietanas trazem a grelha das práticas jesuíticas que servirão para o corte dos discursos dos oradores leigos: em seu discurso, Eduardo Prado ressalta a vocação da Igreja Católica que teve na América o papel de ensinar e civilizar as diferentes raças, favorecendo a sua união de que resultou a mestiçagem que caracteriza o povo paulista. Joaquim Nabuco, que também vê a identidade nacional forjada pela fusão de raças, assinala que a identidade nacional e a unidade territorial também devem ser creditadas à ação do catolicismo na América portuguesa. Francisco de Paula Rodrigues correlaciona o avanço da civilização com a expansão católica e a moralização da família e da sociedade, e o cônego Manoel Vicente da Silva sobreleva a religião procurando desconstruir o materialismo e o evolucionismo, ideologias que ganhavam projeção na conjuntura sócio-histórica do período.

Com exceção da primeira leitura ocorrida na Catedral da Sé em 17 de junho de $1896^{29}$, as demais se deram, como mencionado acima, no ambiente da biblioteca da Academia de Direito. Circunscrever a leitura dos textos ao ambiente da Academia parece ter sido uma estratégia de autopreservação dos oradores, uma vez que o jacobinismo corria solto e os monarquistas passaram a ser perseguidos ${ }^{30}$. Na década de 1900, a compilação dos textos relativos às Conferências Anchietanas em um único volume intitulado III Centenário da Morte do Venerável Joseph de Anchieta, organizado por Eduardo da Silva Prado, alcançava uma dimensão espacial e social diferente daquela encontrada pelos oradores em 1896 e em 1897. Na conjuntura da colação de grau dos bacharéis em Letras pelo ginásio do Colégio São Luís, esses temas eram retomados

\footnotetext{
${ }^{29}$ A leitura teria se iniciado um ano antes do centenário da morte de José de Anchieta (09 de junho de 1897), devendo se estender por um ano. Convencionou-se que no aniversário de morte de Anchieta seria realizada a última leitura, a de Joaquim Nabuco. Entretanto, os textos de Nabuco, de Couto de Magalhães e de Manoel Vicente da Silva não foram lidos publicamente.

${ }^{30}$ Eduardo da Silva Prado deixou o país nesse período.
} 
dentro do espaço jesuítico, trazidos por oradores leigos que faziam o movimento da Arcada para o Colégio, não apenas legitimavam as práticas jesuíticas mas faziam do Colégio o duplo da Academia.

\section{Biblioteca Histórica da Igreja do Bom Jesus}

A Biblioteca Histórica da Igreja do Bom Jesus, em Itu, conserva uma coleção de livros e periódicos que ficou guardada após o encerramento das atividades dos membros da Companhia de Jesus no ano de 1992. Entre dois corredores de estantes enfileiradas em uma sala fechada no fundo da Igreja, pudemos encontrar algumas obras salutares que correspondiam ao tipo de delimitação que fizemos para a pesquisa:

- Lettere edificanti dei PP. Della Compagnia di Gesù Della Provincia Romana (Italiano)

- Catalogus Provinciae Romanae Soc. Jesu - Missio Brasiliensis - 1874 1909 (Latim)

- Catalogus Missiones Brasiliensis - Provinciae Romanae Soc. Jesu - 1909 - 1925 (Latim)

- Revista Mensageiro do Coração de Jesus

- Seleção de notícias dos jornais Federação e A República.

As duas primeiras obras, embora não escritas em português, trazem informações importantes sobre o cotidiano dos padres jesuítas no ambiente do Colégio e da Igreja. As "cartas edificantes" fazem parte das atribuições ordinárias de cada membro da Ordem em compartilhar os acontecimentos, as dificuldades e resolução de problemas junto a seus superiores. No fragmento, a carta relembra as benfeitorias feitas pelo $\mathrm{Pe}$. Campos, a fundação da escola apostólica em Itu e de uma fazenda anexa:

Giunto il P. Campos al Brasile, si diede a propagare il culto di Maria SS.; construi una cappella, ed espose quel quadro alla pubblica venerazione; $e$ vi fabbricò dappresso un seminario per formarvi nuovi sacerdoti, con un podere annesso. Morì il benefattore Ituano, lasciando incompiuta la 
costruzione della chiesa, che fu poi da altri finita. Il vaticinio del fanciullo si è avverato. La chiesa della Madonna del Buon Consiglio há da um lato la scuola apostolica, dall'altro il grandioso collegio d'ltù. ${ }^{31}$

Quanto aos catálogos, estes se referem ao registro da organização hierárquica dos membros e da designação de suas atividades em cada uma das casas da Ordem, seja nos colégios espalhados pelo Brasil, ou nas residências das Igrejas. No exemplo abaixo, a enumeração dos religiosos presentes em Itu, na residência do Colégio e da Igreja do Bom Jesus. Encontram-se, ainda, informações sobre as disciplinas lecionadas, os anos de trabalho dos docentes e as atribuições de cada religioso:

COLLEGIVM ITVENSE SANCTI ALOISI/ ${ }^{32}$

(Collegio de S. Luiz - Itu - Estado de São Paulo- Brazil) 1902

P. Iustinus Lombardi, V. Sup. Miss. A die 27 Sept. 1900, Rector a die 1 Maii 1900, Praef. Stud.

P. Vincentius Giorgini, Min.dom., Proc. Miss. Et coll., Praef. Valet. NN., Cons. Miss. Et dom. an.1

[...]

PRAEFECTI CONTVB. ET MAGISTRI

Iosephus Accioli, Praef. alt 2 contub., Doc., ling.lusit.lat, diagr. Et geogr. in 2 cl., arith. in 1 cl., an. 1 mag.

$[\ldots]$

COADIVTORES

$[\ldots]$

AD RESIDENTIAM BONI IESV

P.Bartholomeu Taddei, Dir. diocesan. Apost. Ort., Conf.dom. et in templ., Oper.

COADIVTORES

\footnotetext{
${ }^{31}$ Tradução livre: Agora o P. Campos, do Brasil, deu a propagar o culto da Sagrada Maria; construiu uma capela, e explicou a estrutura para veneração pública; e edificou ali perto atrás de um seminário a fim de formar novos padres, com uma fazenda adjacente. Morreu o benfeitor Ituano, deixando o prédio da igreja inacabada, que mais tarde foi terminado por outros. A profecia da criança se tornou realidade. A igreja de Nossa Senhora do Bom Conselho ao lado da escola apostólica, a outra grande escola de Itu.

32 Neste documento, estão citados os nomes dos jesuítas: P.Lombardi, P. Giorgini, P. Accioli, P. Taddei, e suas designações no Colégio São Luís, de Itu, no ano de 1902.
} 
As três fontes seguintes, publicações da imprensa ituana, permitiram não só a percepção das dinâmicas de interação entre os grupos sociais, como possibilitaram a composição do corpus de análise linguística. São publicações representativas da primeira década do século XX, entre os anos de 1900 a 1908, que revelam o que Bakthin (2003) denomina de diálogo inconcluso, pois manifestam a realidade em constante formação, com sujeitos sociais e históricos em seus "sistemas de valores", posicionando suas visões de mundo e respondendo aos diálogos criados com o outro grupo.

\section{Revista "Mensageiro do Coração de Jesus"}

A revista Mensageiro do Coração de Jesus - orgam mensal do Apostolado da Oração e da Communhão Reparadora no Brazil é a publicação da primeira tipografia aberta em Itu pelos jesuítas no ano de 1896: A Typografia a Vapor do Apostolado, criada pelo Pe. Bartolomeu Taddei, firmou-se como ferramenta do trabalho apostólico e missionário, sobretudo junto ao Santuário Geral do Apostolado da Oração. O periódico tem seu primeiro exemplar publicado em junho daquele ano e, entre seus redatores, estão os padres jesuítas. O fundador expressa o contentamento com a primeira edição: "Chegou este dia, em que o Apostolado do Coração de Jesus no Brazil pode contar com o seu orgão official" ${ }^{33}$.

\footnotetext{
${ }^{33}$ In: http://www.mensageirodosagradocoracao.com.br/revista.asp, pesquisado em 27/11/2015.
} 


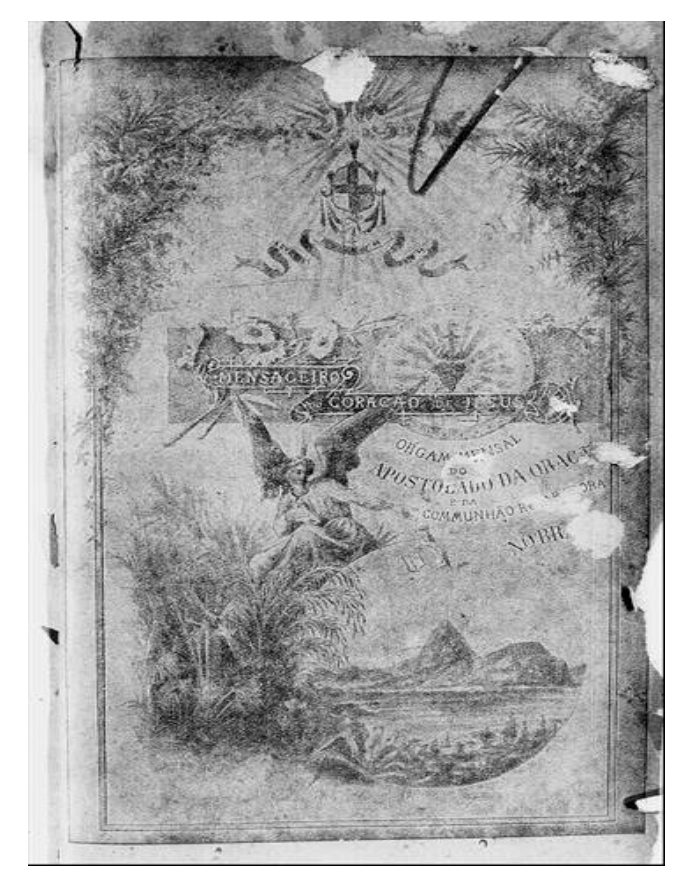

Figura 5 - Revista Mensageiro do Coração de Jesus Typografia a vapor do Apostolado- Ytú (S. Paulo)

A capa traz, ao lado das inscrições, o desenho de um anjo olhando para a Baía de Guanabara, contemplando seus atributos naturais, a praia, os morros, a vegetação. Os morros representam a concepção católica implementada no Brasil naquele momento, o ultramontanismo. Outro símbolo aparece logo acima, a imagem de veneração do Imaculado Coração de Jesus: um coração envolvido por ramos de espinheiro de onde saem chamas e uma cruz. A composição mimetiza a obra dos missionários junto a "terra dos papagaios"34, natural, intocada, pronta para a evangelização. Na parte de dentro, duas frases: A primeira é de Leão XIII: "A obra do Apostolado da Oração é tão boa, ella reune uma fecundidade extrema em tal simplicidade, que merece certamente toda a protecção da autoridade ecclesiastica". A outra é uma nota da redação: "Os Exms. Srs. Arcebispo da Bahia e Bispo de Nictheroy concedem 40 dias de indulgencia aos seus diocesanos que lerem o Mensageiro do Coração de Jesus".

\footnotetext{
${ }^{34}$ Referência ao termo usado por Neves (1978) para descrever o trabalho dos jesuítas no Novo Mundo.
} 
Em seus anos iniciais, a revista foi subdividida nas seções: (I) Intenção geral do mês, parte inicial destinada a mostrar aos fieis a causa pela qual deveriam orar; (II) Saudação aos assignantes; (III) Texto escrito pelo redator-chefe; (IV) A voz do episcopado em favor de nossa manifestação a Jesus; (V) Texto evangelizador (geralmente texto bíblico); (VI) Discipulos do Coração de Jesus; (VII) Movimento do Apostolado no Brasil (notícias sobre o movimento do apostolado nas diversas localidades brasileiras); (VIII) Casos edificantes (testemunhos de fé, perseverança, caridade, abnegação); (XIX) Revista dos Interesses (pequenas notas); (X) Notícia; (XI) Poesia/ textos ficcionais edificantes; (XII) Graça alcançada (parte destinada a leitores que mandavam seus agradecimentos pelos graças alcançadas). Tal subdivisão define 0 empenho do grupo do Apostolado na expansão da religião pelo país.

A relevância da revista para a compreensão das ações dos jesuítas fora dos muros do Colégio é evidente. Além das ações educativas, os jesuítas desempenhavam inúmeras atividades paralelas. Padre Tadde ${ }^{35}$, aclamado como uma das figuras mais expressivas do clero brasileiro na passagem do XIX pro XX, fomentou a ação apostólica em sua vertente social, com um centro Apostolado de Oração que, numa operação ostensiva, deu origem a fundação de diversos outros centros de devoção do Sagrado Coração de Jesus pelo Brasil. $O$ trabalhou seguiu no sentido de que o catolicismo brasileiro "fosse mais ligado à Igreja de Roma e menos envolvido com tradições coloniais, das antigas irmandades e confrarias", obviamente para frear o laicismo republicano e o Protestantismo crescente.

Todos conhecem a nova ordem de coisas que nos ultimos tempos se formou contra a mesma Egreja. O liberalismo, assaltando seus direitos, tem querido alienar os povos de seu dominio, começando por quebrar a união entre a Egreja e o Estado, ou, quando não o consegue por enfraquecer essa mesma união, tornando os governos despotas contra a Egreja, sob a capa de uma concordata ou de um protectorado hypocrita, o que val o mesmo, senão peior, que a separação official; para depois

\footnotetext{
${ }^{35}$ Padre Taddei foi responsável ainda por celebrações que envolveram grande número de fiéis, levando a Itu dezenas de bispos, arcebispos e o cardeal D. Joaquim Arcoverde.
} 
estabelecer leis attemtatorias da liberdade de consciencia, corruptoras da moral, oppressoras de direitos reconhecidos; inaugurando dest'arte a era das revoluções, que tem por fim a destruição da ordem e da autoridade da familia e da paz social, faltando-Ihes o apoio prestado pela influencia da religião. (M.C.J)

O laicismo na educação era uma das preocupações mais proeminentes e o combate se dava pela justificação de uma educação católica voltada aos valores morais.

Consequencia logica da liberdade da consciencia é a liberdade da educação: mas esta tambem querem sujeitar ao deus Estado, attribuindoIhe $o$ direito de formar ad imaginem et similitudinem suam a alma dos cidadãos. Não a Egreja, mas o Estado é infallivel, segundo a pratica delles: por conseguinte infallivel é o ensino, que manda dar em suas universidades. Donde se segue que o Estado e seus mestres não tem obrigação de respeitar os ensinos da Egreja; mas a Egreja e seus lentes devem conformar seu ensino com o do Estado! (M.C.J.)

\section{Jornal A Federação}

O jornal A Federação - Orgam das Associações Catholicas de Ytú foi fundado em maio de 1905 pelo Padre Elisiário de Camargo Barros, com a colaboração de outros personagens, dos quais se destaca a figura de Francisco Nardy Filho, historiador cuja obra narra a história da cidade. 


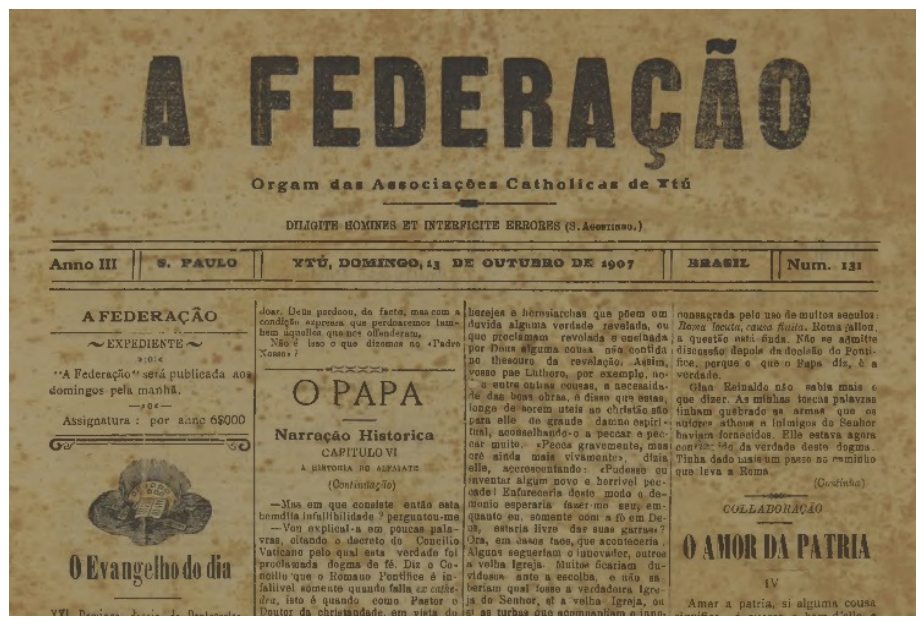

Figura 6 - Jornal A Federação - Orgam das Associações Catholicas de Ytú 13 de outubro de 1907

Ao imaginar a Companhia de Jesus como uma unidade corporativa de um por todos e todos por um, os textos publicados no jornal Federação captam a responsividade do grupo às investidas do grupo republicano.

\section{Jornal Republica}

O jornal Republica-Orgam dos interesses do municipio circulou entre os anos de 1890 a 1926 e teve como editores Affonso Borges e Francisco Cintra. A publicação representa o período de configuração do regime republicano. Trata-se de um jornal que se define laico por não se colocar em benefício de nenhuma instituição a não ser dos interesses públicos. Logo na primeira coluna, a informação de que o jornal "não é responsável pelas idèas emittidas em artigos assignados": 


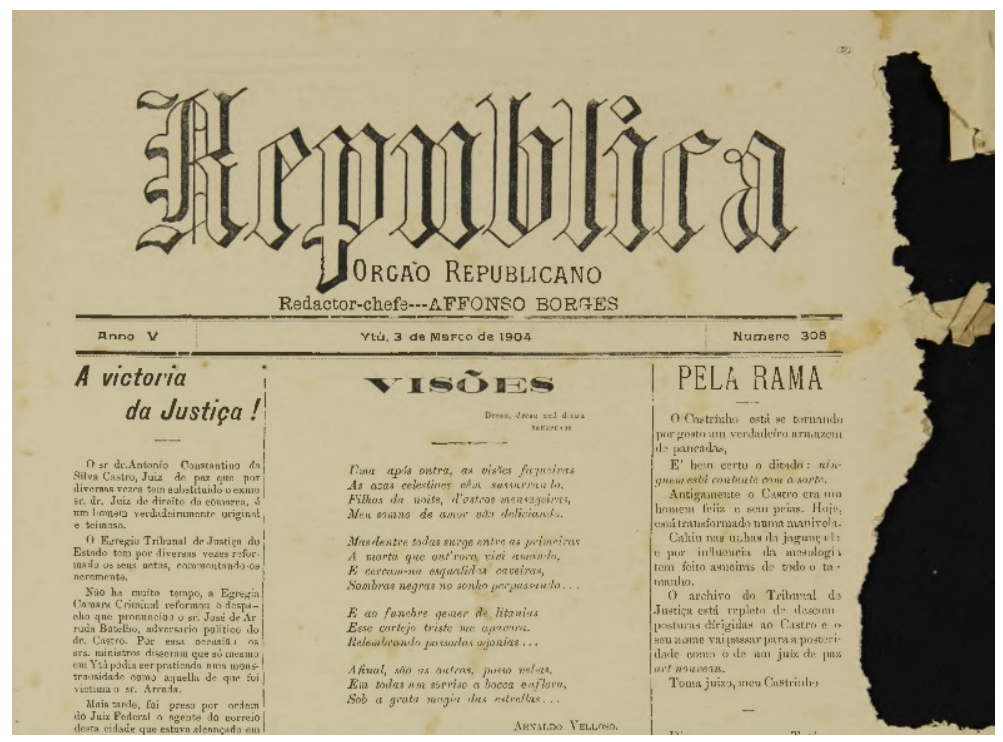

Figura 7 - Jornal Republica - Orgão Republicano

Março de 1904

Os jornais proporcionam a compreensão das identidades dos grupos, remetendo ao clima de opinião e às polêmicas que pairavam na cidade, como as investidas de cada grupo acerca de posicionamentos políticos, do binômio educação laica versus educação religiosa ou sobre o crescente protestantismo na região. Esses assuntos encheram as páginas dos jornais durante os anos da primeira década do século XX. Abaixo, recuperamos uma parcela das manifestações do grupo católico, que liderava o jornal Federação e do grupo de republicanos, em seu jornal Republica:

No dia 7 de março de 1907, o jornal Republica publica uma carta enviada à redação do jornal de um protestante na qual faz severas crítica à ação de uma comissão de senhoras católicas que angaria assinaturas em favor dos jesuítas contra uma associação liberal da região, o Centro Regenerador:

Bem sabemos que o vosso jornal nada tem que ver com a lucta entre clericaes e anti-clericaes, mas um jornal neutro não deixará, por certo, de dar acolhida a um protesto justo, como é o nosso. 
Anda por ahi uma commissão de senhoras angariando assignaturas para uma moção de solidariedade aos jesuitas e de protesto contra a attitude assumida, ultimamente, pelo "Centro Regenerador".

Essa commissão desempenha um mandato conferido pelos padres do Bom Jesus que não puderam encontrar em homens quem pudesse cumpril-o.

Demais a mais, uma commissão de homens não poderia penetrar sorrateira, no lar das familias para ardilosamente conseguir assignaturas de senhoras ingenuas e desprecavidas. (REPUBLICA, 7/3/1907 N.567)

O mesmo jornal republicano publica, uma semana depois, uma carta de leitor que apresenta irônicas críticas a um missivista do jornal Federação, dizendo que esta pessoa escreve "mal" em favor dos jesuítas:

"Os jesuitas não se acham muito garantidos com os seus defensores.

[...]

Conhece historia do Brasil como qualquer argentino, escreve portuguez como nós escrevemos grego e falla em virtude como um homem que nunca soube o que foi o vicio!

[...]

Não leu os classicos, não folheou os dicionarios, de jornaes correu os olhos só em "Rio Nú", "Pimpão" e "Federação" e depois, quando o marasmo senil lhe convence que é articulista eximio, atira-se aos sermões de Monte Feltro, aos prefacios de Historia do Brasil e faz figura triste.

Enquanto T.M. copia os seus artigos para encher as columnas do orgam jesuita, o sr. José Victorio tira um dó do peito e jura que estará á frente de qualquer reacção contra os anti-clericaes."[REPUBLICA 15/3/1907 N.569]

$\mathrm{Na}$ sequência, o jornal Republica ainda publica uma carta de um "amigo e illustrado conterraneo", em que critica o catolicismo defendendo que os dogmas antigos já não contentam o homem daquela época e que o Centro Regenerador é um "fantasma aterrador" para os católicos que insistem em antigas práticas: 
Num tempo em que os dogmas persistem em suffocar o pensamento humano, num tempo em que a pressão clerial, tende obstar o desenvolvimento da sciencia, num tempo em que a autoridade da Igreja quer supprimir o direito de discussão, - a instalação do "Centro Regenerador" entre nós, não pode mesmo passar, para os seus contrarios, dum fantasma aterrador.

$[\ldots]$

O homem actual, o homem que pensa, quer saber o porque das cousas: e o Romanismo, não podendo satisfaze-lo apega-se aos antigos e corroídos dogmas, que nada esclarecem. [REPUBLICA 17/3/1907 N.570]

Mais uma vez, no dia 24 de março de 1907, o jornal Republica acirra os ânimos noticiando a fundação de um grêmio católico que segrega pessoas que não apresentam as mesmas inclinações religiosas. Na notícia, o jornal condena a ação dos católicos ao pedirem aos fiéis que não comprem gêneros alimentícios em lugares que não sejam dirigidos por católicos:

Vem alí a noticia da fundação d'um gremio clerial com o fim expresso de segregar do seu convivio pela falta de trabalho e, portanto pela fome todos aquelles que militam em arraiaes contrarios.

Vem ali a nota de excommunhão até aos inoffensivos generos alimenticios provenientes do adversario.

Vem ali a prohibição até do mais elementar dever de polidez, qual o de saudação aos que não commungam das mesmas ideias. [REPÚBLICA 24/03/1907 n.572]

Em contrapartida, o jornal católico Federação fala sobre o crescimento do protestantismo que, em época de liberdade de culto (após Constituição de 1891), ataca as bases do catolicismo, colocando em perigo a Igreja e a manutenção da ordem social.

Cresce entre nós o protestantismo e com elle o perigo da perversão, da divisão social e da perda das almas. Um certo pastor, "lobo rapaz que vem a nós com pelle de ovelhas", anda na cidade fazendo sermão e prédicas, onde se desfigura a religião catholica, se ataca a auctoridade do Papa, se 
negam os dogmas, e se ultraja a Maria S.S. nossa Mae do céu, a excelsa Padroeira desta cidade de Ytú. (A FEDERAÇÃO 9/2/1908 Anno III n.148)

A difamação dos católicos pelo jornal oponente continua pelo viés da fofoca (ELIAS, 2000[1965]) registrando a investida do jornal Federação nos trâmites da política municipal. O artigo publicado no jornal Republica, com o título "O dedo delles" faz menção ao envolvimento dos católicos em trâmites municipais:

Sob a epigraphe - Ao Léo, a Federação de domingo ultimo, atira-nos uma injusta pedrada, porque aceitámos na secção livre um artigo assignado por um propagandista protestante. A Federação orgam da boa imprensa tem admitido que as suas columnas, após o evangelho do dia, servirão de instrumentos para expansões de odios politicos contra os amigos do governo, contra a Republica, envolvendo-se nos pleitos eleitoraes, nas causas municiapes e na politica local, com noticias ironicas e commentarios de requintada hypocrisia. [REPUBLICA, 1/11/1908 N.817]

A rejeição aos jesuítas também é vista no irônico comentário à implantação de outras linhas de catolicismo na cidade, definindo os jesuítas como agressivos defensores de um catolicismo retrógrado e moralizante:

Graças a Deus, é uma realidade a implantação da fé catholica evangelica na cidade de Ytu, que não é mais o reducto inexpugnavel do jesuitismo intolerante, que, ainda há bem pouco tempo, apontava o muque com a ultima ratio contra aquelles que tinham tido o atrevimento de plantar 0 estandarde da heresia na Roma brasileira. [REPUBLICA, 1/11/1908 N.817]

A estratégia de difamação continua no dia 19 de novembro de 1908 ao ironizarem a tentativa dos jesuítas de encobrirem os professores do CSL envolvidos na polêmica "o dedo delles":

Os leitores devem estar lembrados que noticiamos, há dias e com bastante prazer, que o sr. Reitor do collegio S. Luiz, acompanhado do padre Ronchi, 
veiu ao escriptorio da nossa redacção, a proposito do nosso artigo o dedo delles.

(...)

Assim, que estamos informados de que É. L'epée é o bacharel José Leite Pinheiro, professor no collegio e Juca Luiz é o bacharel Manoel Maria Bueno, tambem professor do mesmo collegio.

O reverendo Reitor nos disse que o collegio não tem nada com o caso, mas alguns professores do estabelecimento vivem a nos fazer fosquinhas naquelle jornal, que podia ser sinceramente um orgam catholico.

O que dizemos com provada verdade, é que as associações catholicas estão pagando seu cobrinho para servirem de instrumentos a individuos, que não tem coragem de enfrentar a lucta a descoberto. (REPUBLICA, $19 / 11 / 1908$ N.812)

Em resposta, o Jornal Federação procura a defesa dos jesuítas, definindo o grupo de religiosos como apartidários em relação à política local. Na notícia sobre a visita do reitor do Colégio São Luís ao responsável do jornal opositor, diz não participar de qualquer manifestação contra o prefeito municipal:

No dia 12 do corrente o R.P. Manoel Gabinio de Carvalho, dignissimo Reitor do Collegio S. Luiz em companhia do P. Mariano Ronchi, dirigiu-se a casa do Sr. Juvenal do Amaral para dizer-Ihe que os Jesuitas d'esta Cidade empregados na educação da mocidade e no serviço dos fieis, nada tem que ver com a politica local, nem com as desavenças contra o sr. Prefeito municipal como foi publicano por uma folha d'esta Cidade no artigo O dedo delles... [A FEDERAÇÃO 22/11/1908 Anno IV n.189]

As notícias de jornal veiculadas nos dois órgãos da imprensa ituana mostram as lutas travadas pelos grupos na intenção da modificação do equilíbrio de poder. Um grupo exerce uma pressão tácita para provocar a desonra do grupo adversário. A pressão para se colocar como o grupo de poder é o que Elias (2000[1965]) denomina de figuração "estabelecidos-outsiders". A dinâmica observada nos textos levanta a pressão exercida 
pelos republicanos na intenção de diminuir a força do grupo católico. Essa configuração será recuperada ainda nos capítulos posteriores.

Como explicado na Introdução deste trabalho, a organização e descrição do corpus de análise, apresentada neste capítulo, considera os objetivos que nos propusemos a seguir: no capítulo 3, a análise das repetições toma por base os discursos e panegíricos pronunciados nas festividades do Colégio; enquanto a análise linguística da colocação pronominal, no capítulo 4 , toma todo o corpus formado tanto pelos discursos quanto pelos textos da Imprensa. A seguir, fazemos uma breve apresentação do programa da Companhia de Jesus desde sua criação e discutimos a sua reinserção no Brasil após a restauração. Acreditamos que este preâmbulo histórico guiará as discussões que virão nos capítulos de análise textual. Procuramos, assim, reconstruir as práticas jesuíticas no rescaldo das Conferências Anchietanas. 


\section{CAPÍTULO 1 - A QUESTÃO GERAL: O programa da Companhia de}

\section{Jesus}

\section{Introdução}

Este capítulo procura mostrar as bases de trabalho da Companhia de Jesus estabelecidas a partir de sua criação por Inácio de Loyola em 1540, especialmente as relacionadas às ações no campo da educação. Percorremos o caminho dos jesuítas desde a criação da Ordem, o trabalho missionário no Brasil colonial, a expulsão e o reingresso em terras americanas. Esse percurso histórico ajudará a compreender a base do programa jesuítico em seu empreendimento missionário e, consequentemente, na organização de seu programa educacional.

\section{1 - A criação da Companhia de Jesus}

Entre os movimentos religiosos do século XVI que optaram por permanecer sob a liderança papal, destaca-se o da Companhia de Jesus, ordem jesuítica fundada por Inácio de Loyola, que partilhou das reformas do Concílio de Trento e da resposta dos católicos ao protestantismo.

De origem nobre basca, Iñigo Lopez de Loyola ${ }^{36}$ foi um militar que lutou na batalha de Pamplona contra tropas francesas em 1521, ocasião em que foi ferido, motivando o fim de sua carreira militar e direcionando-o para a vida religiosa ${ }^{37}$. Após peregrinação à Terra Santa, instalou-se em Barcelona para aprofundar seus estudos, migrou para a Universidade de Alcalá onde começou a pregar e a administrar seus "Exercícios Espirituais", livro de exercícios criado para a devoção religiosa.

\footnotetext{
${ }^{36}$ Somente aos 38 anos de idade Iñigo adota o nome de Inácio de Loyola.

${ }^{37} \mathrm{O}$ ideal cavalheiresco marca a Espanha de fins do século XV e início do século XVI, o que explica a íntima relação entre o universo militar e a criação de uma Companhia que visava lutar contra os infiéis. A concepção medieval das cruzadas estará presente no nascimento da Companhia de Jesus.
} 
Tido como "Alumbrado"38, Loyola foi perseguido pela Igreja que julgava o movimento "uma ameaça ao dogma de que os sacramentos e a Igreja eram os únicos que podiam mediar a devoção. Foi ainda para a Universidade de Salamanca, mas mais uma vez seu conhecimento de teologia e seus métodos geravam suspeita e a Igreja o impedia de pregar. Assim, partiu para Paris, onde concluiu seus estudos e travou conhecimento com pessoas de diversas origens com as quais consolidou seu grupo. Esses primeiros jesuítas, entre os quais se achavam o navarro São Francisco Xavier e o português Simão Rodrigues, fizeram votos de pobreza, castidade e dedicação ao serviço pastoral na Igreja dos Mártires de Montmartre.

\section{2 - As Constituições - mobilidade, hierarquia e obediência}

E é tambem Luiz modelo perfeito para esta pobre mocidade solapada no principio da ordem, que é o respeito á auctoridade legitimamente constituida e ás suas leis, e isso quer na ordem social quer na religiosa.

Ai! Que eu sei, que o terdes sido alumnos deste collegio será o alvo, para onde hão de convergir os remoques e escarneos semsaborões e impios dos que vos não poderão ter por cumplices do que não cabe na lingua dizer deste logar sagrado.

Pe. FIALHO

O documento fundador da Companhia são as Constituições definidas no texto da Fórmula do Instituto de 1539, aprovadas após a bula papal Regimini Militantes Ecclesiae que criou a Ordem em 27 de setembro de $1540^{39}$. As Constituições publicadas entre os anos de 1558-1559 são normas que regem organizam a Companhia de Jesus e a vida de seus integrantes, de tal forma a criar uma grande coesão interna, fixando objetivos, métodos de atuação e regras para ingresso e permanência de seus membros. ${ }^{40}$

\footnotetext{
${ }^{38}$ Movimento religioso espanhol do século XVI que foi perseguido e considerado herético pela Igreja Católica. Originou-se em pequenas cidades da região central de Castela em torno de 1511.

${ }^{39}$ O papa Paulo III foi o responsável pela instituição da Ordem, em 1540.

40 O longo trabalho de redação das Constituições dividiu-se em três partes: (1539-1541) - Inácio e seus companheiros; (1541-1547) - Inácio sozinho; (1547-1550) - Inácio e João Afonso de Polanco.
} 
O texto das Constituições, que é organizado em dez partes, estabelece como finalidade primeira da Companhia a salvação das almas. "O fim da Companhia não é somente ocupar-se com a graça divina, da salvação e perfeição das almas próprias, mas, com esta mesma graça, esforçar-se intensamente por ajudar a salvação e perfeição das do próximo. (CONST., Primeiro Exame Geral, §3). A atividade missionária articula-se fortemente com a ação educacional, amplamente relacionada ao ideal de salvação das almas e com a concepção de que a formação intelectual está inalienavelmente vinculada à virtude. $O$ estudo, além de transmitir conhecimentos, prepara para o apostolado e forma os bons costumes. (PAIVA \& PUENTES, 2000:106)

Para que a ação da Companhia fosse concretizada, era importante assegurar a coesão interna, pois o caráter missionário da Ordem levava seus membros a atuarem em lugares distantes. $\mathrm{O}$ trabalho missionário era regulado pelos princípios de mobilidade e de obediência, entendidos, porém, não como ordens que emanavam de autoridades, mas como disposição interior.

Exigia-se que o jesuíta se comprometesse por meio do voto de mobilidade a não criar laços com a comunidade em que atuava e aceitar a transferência para outras localidades onde fossem designados:

Ao contrário do voto de admissão das ordens monásticas medievais, ele era um voto de mobilidade e não de enclausuramento. Os jesuítas prometiam não criar laços permanentes em qualquer localidade e estar à disposição para levar adiante as boas obras aonde quer que as autoridades assim o desejassem. (EISENBERG, 2000:37)

Esse princípio afastava os procedimentos jesuíticos dos das demais ordens religiosas, como a dos dominicanos, e exigia um processo que harmonizasse os procedimentos, o que se dava por meio da troca de correspondência entre superiores e inferiores (os missionários). De acordo com as Constituições, cada integrante da ordem deveria redigir uma carta relatando os problemas enfrentados e as ações tomadas. 
A obediência "exerceu um papel importante na consolidação da organização jesuítica." (EISENBERG, 2000:36). As regras exaradas pela Companhia deveriam ser interpretadas pelo missionário como produtos de sua própria deliberação consciente. Nesse sentido, a obediência não reflete uma atitude forçada; antes, é assimilada como plena convicção do aspirante aos princípios jesuíticos.

A Companhia não pode manter-se, nem ser governada, nem por conseguinte atingir o fim que pretende para a maior glória de Deus, se os seus membros não estiverem unidos entre si e com a cabeça. (Const., VIII, cap.1, §655)

Essa disposição à obediência dá sustentação à existência da Companhia na medida em que o trabalho jesuítico, sendo missionário, não poderia ser mediado pelos superiores. Longe de sua sede, muitas vezes o missionário era obrigado a tomar suas próprias decisões, tendo como baliza as Constituições da Companhia, caracterizadas por "uma longa e detalhada lista de normas, que supostamente permitia a seus membros, dispersos pelo mundo, agir sem ter que esperar pela chegada de ordens provindas de seus superiores da Europa. [...] no núcleo da organização jesuítica residia a dialética entre as muitas normas contidas na Constituição e os comandos que esporadicamente chegavam aos missionários espalhados pelos quatro cantos do mundo." (EINSENBERG, 2000:45)

Associado ao voto de obediência está o conceito de hierarquia que regula a vida institucional da Companhia e a estrutura nos moldes de uma organização militar. $O$ desenho institucional da estrutura hierárquica da Companhia de Jesus espelha os princípios contidos nos Exercícios Espirituais.

Além da atividade missionária, a Companhia, desde os primórdios de sua fundação, traçou como linha fundamental de trabalho a atividade educacional, cujas linhas principais estão contidas na IV parte das Constituições. Além das orientações sobre a formação moral, filosófica, literária e teológica dos membros, insiste-se também nessa seção nos princípios da hierarquia e obediência. 
A reincidência dos princípios da hierarquia e obediência na parte das Constituições dedicada à atividade educacional sinaliza que a educação jesuítica segue os mesmos moldes traçados para os membros da Companhia: "estrutura do colégio jesuítico é, com efeito, monolítica, fundada sobre uma só pedra, a hierarquia, que tem como correspondente a obediência" (PAIVA \& PUENTES, 2000:107). A hierarquia é compreendida como o elemento que atravessa todos os membros da sociedade, ligandoos e constituindo-os num só corpo. A adesão a esse corpo social, por sua vez, é garantida pela obediência.

O entrelaçamento dos princípios da hierarquia e da obediência tece as relações de mando e submissão. Já o da mobilidade põe os jesuítas na ordem do dia quinhentista, na medida em que o programa missionário, na esteira dos descobrimentos que fazem refluir o sentimento de dispersão e de isolamento das populações. Nesse sentido, a atividade missionária dos jesuítas institucionaliza a consciência de unidade da humanidade vinda à tona pelos acontecimentos das descobertas, mas the atribui um núcleo centralizador do qual emanam as diretrizes da Companhia para as suas missões. 


\section{3 - Os colégios e a concepção educacional dos jesuítas - o Ratio Studiorum}

As Universidades se foram instituindo após a emancipação das communas e as Cruzadas; mas, não obstante, as Ordens Religiosas continuaram a manter e propagar escolas, até que, no seculo XVI, o mundo contemplou o apparecimento desse instituto insigne, que, na phrase completa de um escriptor, - «se apresentava com as fórmas de um colosso e punha em pratica as forças de um gigante», a Companhia de Jesus.

JOÃO MENDES

A formação de Loyola e de seus primeiros seguidores na Universidade de Paris ${ }^{41}$ foi essencial para a criação do método educacional da Companhia. As universidades francesas a essa época haviam desenvolvido uma metodologia que dividia os alunos em níveis de aprendizagem, elaborava exercícios de repetição, disputas, jograus e outros processos. A esse método deu-se o nome de Modus parisiensis. O método francês contrapunha-se ao praticado na Itália, o Modus italicus, que se caracterizava por não seguir um programa estruturado, nem definir as disciplinas de estudo dos alunos ${ }^{42}$. É a metodologia francesa que guia a composição das orientações educacionais da Companhia, com a criação do Ratio Studiorum.

O Ratio atque Institutio Studiorum Societatis lesu, ou simplesmente Ratio Studiorum, surgiu da necessidade de unificar o procedimento pedagógico dos jesuítas diante do aumento gradativo dos colégios ${ }^{43}$ da Companhia de Jesus como base de uma expansão da tarefa de evangelização. A concepção de ensino é a de que o conhecimento "deve ser produto da prática coletiva dos padres que repetem saberes autorizados como

\footnotetext{
${ }^{41}$ Inácio permaneceu em Paris entre os anos de 1528-1535.

${ }^{42}$ Os alunos podiam cursar as disciplinas, transitar entre uma disciplina e outra sem nenhum requisito anterior.

${ }^{43} \mathrm{O}$ pe. Claudio Acquaviva organizou a comissão de padres vindos de vários países. A elaboração do Ratio foi lenta, tendo sido finalizada em 1599. O primeiro colégio jesuítico destinado a estudantes laicos foi o de Messina (1548). Em seguida fundou-se o de Palermo (1549) e, no ano seguinte, o "ilustre" Colégio Romano, considerado como modelo de todas as instituições pedagógicas jesuíticas. No ano da morte de Loyola (1556), a Companhia já contava com 42 colégios. Em 1579, eram 163 e, em 1710, 714 colégios espalhados pelo mundo.
} 
aplicação imediatamente útil." (HANSEN, 2001:15). Trata-se, assim, de uma sistematização guiada pelo Geral da Companhia, o pe. Claudio Acquaviva, em 1583, que organizou uma comissão inicial de 12 padres para formular a ordem de estudos dos jesuítas mas que só atingiu êxito ao formar a segunda comissão com seis eruditos e especialistas em ensino, nomeada em 1584. Depois de quinze anos de trabalhos, os primeiros textos provisórios foram finalizados e entregues para exames nas Províncias. Os textos continham as regras sobre as atividades docentes que objetivavam garantir uniformidade de conduta entre educadores para a formação dos alunos, com a definição de métodos, conteúdos e diretrizes.

São três as modalidades de currículos: o primeiro, o Teológico, desenvolvido em quatro anos, abrangendo a Teologia Escolástica e Moral, a Sagrada Escritura, Direito Canônico e História Eclesiástica; o segundo, o Filosófico, em três anos, baseando-se nas doutrinas de Aristóteles e Santo Tomás; e o terceiro, o Humanista, com duração de seis ou sete anos, com dedicação à Retórica, Humanidades, Gramática Superior, Média e Inferior.

O Ratio Sudiorum além de descrever métodos de ensino e de aprendizagem, preceitua as condutas e posturas, orientando que o estudo não deve ser desvinculado das virtudes cristãs. Os conhecimentos são adquiridos "por meio da exercitação de modelos ou auctoritates, autoridades, cuja repetição, feita na forma de exemplos, acontece como treinamento constante da ação e para a ação" (HANSEN, 2001:18). O programa descreve os conteúdos e indica os textos para estudo. No âmbito dos estudos linguísticos, "exigia-se a elaboração de composições escritas com aprimorado rigor; liamse autores greco-romanos, em especial Aristóteles, Cícero, e a retórica propunha formar o perfeito orador." (FRANCA, 1952:8)

Os jesuítas elegem o ensino do Latim em detrimento das línguas nativas; definem os autores a serem lidos, no caso os autores clássicos; explicitam também os trabalhos, exercícios orais e escritos, as dinâmicas de classe: 
O apuradíssimo estudo do latim privilegiava leitura de autores clássicos, manejo das normas gramaticais e auxiliava no domínio das línguas pátrias, que, gradativamente, iam se inserindo no currículo. Integralizavam os trabalhos em aula exercícios complementares, teatro, discursos, declamações, academias, pregações no refeitório, premiações..., trilhando o ensino a dimensão humanístico-tradicional. (FRANCA, 1952:10)

Pela organização dos conteúdos, a Ordem definiu um currículo altamente estável e promoveu a difusão de certa cultura intelectual e o conhecimento das línguas clássicas.

A pedagogia prevê: a preleção, em que se aborda um texto etimológica, gramatical, literária e historicamente; os estudos individuais e em grupo com exercícios escritos, pesquisas, heterocorreções; a emulação, considerado como um incentivo para os certames, debates, desafios, disputas, exposição de trabalhos, premiações, estimulando a entrada em Academias; a memorização, consistindo da repetição dos pontos das lições, declamações e representações teatrais.

A segunda parte do Ratio, intitulada "Organização e Plano de Estudos da Companhia de Jesus", prescreve regras e detalha a atuação de cada integrante no processo educativo: Provincial, Reitor, Prefeito, Professores, Ajudante do Professor (ou Bedel), Escolásticos e Alunos Externos da Companhia.

As instruções expressas para cada um dos actantes no processo educacional são normas estritamente coercivas que descrevem as designações de mando e submissão previstas para os membros das Ordem em relação às atividades educacionais. 


\section{4 - A disseminação dos ideais jesuíticos - definição e controle do conhecimento}

Como vimos no início deste capítulo, a base da organização jesuítica é a hierarquia e a obediência. Na instituição escolar jesuítica, isso não era diferente. Aqui, procuramos discutir a repercussão dessa "maneira de ser" na definição do currículo dos colégios e universidades jesuíticos, ressaltando a escolha de determinados conhecimentos em detrimento de outros.

A restrição conteudística foi polemizada já nos primeiros tempos da Companhia em que se travou a polêmica entre jesuítas e cientistas do renascimento europeu, principalmente na questão formada em relação aos estudos de Galileu e Copérnico nos séculos XVI e XVII e nas repercussões acerca do desenvolvimento das ciências do período.

Ao não permitir a disseminação de novos conhecimentos científicos, isto é, aqueles não aprovados nas Universidades católicas jesuíticas da Europa daqueles séculos, a Igreja institucionalizava a intolerância. Com o poder jurídico conferido aos jesuítas pela Igreja via Inquisição, designou-se a relevância de certos conteúdos em detrimento de outros, mais especificamente, em relação àqueles advindos da pesquisa científica.

A escolha dos conteúdos por parte da Igreja foi balizada pela defesa de seus dogmas e de suas tradições. Não se deve esquecer que a Companhia de Jesus surgiu num momento em que a Igreja Católica enfrentava a necessidade de se reformar, tanto por questões concernentes à reforma protestante, como também pelas mudanças políticas, sociais e culturais atravessadas pela Europa. A política cultural da Igreja, entretanto, vinha na contramão do conjunto de mudanças operadas na sociedade renascentista, e os jesuítas, detentores e organizadores dos currículos das universidades, lutavam para reforçar todo um sistema de crenças cujas bases tinham sido enfraquecidas pelas descobertas telescópicas de Copérnico: 
[...] De 1610 a 1632, assiste-se à constituição gradativa de uma estratégia combinada de defesa do copernicanismo e de ataque vigoroso à cosmologia tradicional e à visão de ciência na qual ela se assenta. (MARICONDA, 2000:79)

A Igreja procurou meios para frear o avanço dos estudos cosmológicos que confrontavam e punham em situação perigosa os pontos fundamentais de todo o sistema de crenças católico. Para expurgar os "produtos culturais inovadores" que se contrapunham aos dogmas católicos como a teoria do heliocentrismo de Galileu, a cultura contrarreformista, em defesa da tese cosmológica aristotélica da incorruptibilidade dos céus, apelou para a intolerância religiosa que, ao exigir obediência aos seus dogmas, aliava a censura e a aplicação de recursos jurídicos.

A tese da incorruptibilidade dos céus ganhou sustentação com a indicação dos textos fundantes e autorizados pelo Concílio do Trento (1546): a traditio e as Escrituras. Opondo-se à reforma luterana (1517) que declinava a mediação do clero e os ritos e cerimônias eclesiásticas, o Concílio entronizava a traditio e lhe atribuía Cristo como fonte. Ritos, cerimônias, magistério, ministério e governo eram garantidos pela traditio. Por sua vez, a interpretação dos textos bíblicos fiava restrita a alguns teólogos, que retinham o monopólio do sentido profético. Para alimentar tais disposições conciliares, o jesuíta Francisco Suárez (1614) buscou no Evangelho de São Lucas e no Evangelho de São João o ensinamento de São Paulo que vinculava a palavra dos homens (da lgreja) à palavra de Deus (HANSEN:2011).

Nesse sentido, o princípio da obediência da Companhia de Jesus estava em completo alinhamento com a postura da Igreja. O significado da submissão à autoridade papal, definida por Loyola nas Constituições não só representava o respeito à figura soberana do papa na hierarquia da Igreja, como também a todas as decisões decorrentes dessa aceitação:

Com efeito, para pertencer à ordem jesuítica, exige-se um voto especial de obediência ao papa, no qual está explícito o 
reconhecimento da soberania e infalibilidade papais e a submissão incontestável dos jesuítas à autoridade papal. O princípio de autoridade constitui, assim a espinha dorsal que dá organicidade a todas as atividades dos jesuítas, porque é nele que se assenta sua vocação tradicionalista de defesa do catolicismo contra os reformados e seu zelo missionário excepcional fora da Europa na cristianização dos povos recém descobertos." (MARICONDA, 2000:86)

Esteada no princípio da obediência, a educação nas escolas jesuíticas, seja nos colégios como nas universidades, cumpria a missão de levar a ideologia da instituição à sociedade ao se dedicar à formação de "soldados" da Igreja armados e treinados, os quais contribuiriam para converter os pagãos e combater os heréticos. Para isso, a Companhia de Jesus investiu pesado na formação de filósofos, teólogos, juristas e matemáticos alinhados aos seus preceitos, por meio da fixação das três modalidades de currículo - Teológico, Filosófico e Humanista.

\section{5 - A proposta jesuítica de educação no Brasil colônia}

O entrelaçamento do elemento cultural ao religioso e do poder político ao religioso, que caracterizavam o catolicismo tradicional, tornaram os monarcas portugueses os chefes efetivos da Igreja. Além disso, as Bulas de Alexandre VI44 atribuíam aos reis de Portugal a tarefa de evangelizar os povos recém conquistados com os descobrimentos de que resultam as primeiras missões jesuíticas em solo americano. Nesse sentido, "Cristianização e evangelização das terras descobertas tornaram-se parte integrante da própria expansão colonial portuguesa." (WERNET, 1987)

No processo de tomada de domínio das terras recém descobertas, os jesuítas chegaram ao continente junto com a armada de Tomé de Souza, erigindo o primeiro colégio jesuítico em Salvador. Além de avançarem para Pernambuco, esses primeiros

\footnotetext{
${ }^{44}$ Durante o pontificado de Alexandre VI (1492-1503) destacam-se as bulas Inter Coetera, Eximiae Devotionis $e$ Dudum Siquidem, entre as quais se estabelece a divisão das possessões portuguesas e espanholas no mundo.
} 
religiosos foram pouco a pouco ganhando o sul do país, interessados na disseminação da fé católica e na educação dos nativos. Abriram escolas de instrução elementar em Porto Seguro, Ilhéus, São Vicente, Espírito Santo, São Paulo, Rio de Janeiro, Pernambuco e Bahia. No início do século XVIII, instalaram residências sacerdotais e colégios em Paranaguá e em Santa Catarina. No total, entre os séculos XVII e XVIII, foram 36 missões, 25 residências e 17 colégios e seminários em território brasileiro.

Apesar do regime de Padroado, que garantia o predomínio do Estado sobre a Igreja, a grande expansão do poder jesuítico preocupou as autoridades portuguesas, que viam na Companhia um segundo governo. Assim, pelo Alvará Régio de 28 de junho de 1759, Sebastião José de Carvalho e Melo, o Marquês de Pombal, como posteriormente ficou conhecido, extinguiu as escolas e colégios jesuíticos de Portugal e de todas as colônias, substituindo-as por "aulas régias", autônomas e isoladas, de Latim, Grego, Filosofia e Retórica.

As ações do secretário de Estado português retiravam a educação das mãos dos jesuítas cuja responsabilidade foi absorvida pelo Estado. O modelo de educação voltado à fé não interessava mais e, por isso, seguiu-se a expulsão de 600 jesuítas e o confisco de seus bens. Essa ação teve um impacto tanto em Portugal como na colônia, significando a destruição do "único sistema de ensino existente no país", como apontam Amaral \& Seco, 2012:

Em lugar de um sistema mais ou menos unificado, baseado na seriação dos estudos, o ensino passou a ser disperso e fragmentado, baseado em aulas isoladas que eram ministradas por professores leigos e mal preparados. (AMARAL \& SECO, 2012:7)

Além dos problemas do ensino nos novos moldes (dispersão e fragmentação) e despreparo dos professores, o Estado português não assumiu o controle de imediato da educação na colônia, pois somente em 1767 Portugal criou a Mesa Régia com a incumbência de administração e direção dos estudos em Portugal e nas colônias, suprindo assim a lacuna deixada com a saída forçada dos jesuítas. 
Se para Portugal as mudanças feitas por Pombal significaram um avanço na educação, incorporando línguas modernas e os estudo das ciências naturais, na colônia significaram um retrocesso pela falta de estrutura das "aulas régias". As ações do governo português não tiveram o êxito pretendido, visto que os professores régios que atuavam em terras tupiniquins trouxeram concepções liberais que contribuíram para incentivar a difusão desses novos ideiais nos anos que antecederam a independência do Brasil.

Há que se ressaltar que os atos pombalinos não foram isolados ou aleatórios, dada a correlação entre política e religião. Com efeito, em 1773 o Papa Clemente XIV proibiu a Companhia de Jesus de atuar em colégios. Apenas em 1814, com o Papa Pio VII, deu-se por encerrada a perseguição à Ordem e se formou uma comissão para revisão do Ratio Studiorum. 


\section{CAPÍTULO 2 - A QUESTÃO LOCAL: Os jesuítas em Itu}

\section{Introdução}

O reingresso dos jesuítas expulsos por Pombal no século precedente trouxe na bagagem o catolicismo ultramontano que se contrapunha radicalmente aos ideais iluministas que vigoravam na região ituana.

As ideias liberais estabeleciam-se na cidade ituana pela conjuntura da economia mercantil açucareira e depois cafeeira, e pela formação dos filhos da elite em Coimbra. Uma das mais antigas vilas da província, Itu ascendeu em meados do século XIX da condição de 'vila' para 'cidade'. De economia predominantemente agrária, sua produção compreendia algodão, chá, fumo, cerejas e outros gêneros; além da pecuária. Apesar da produção bastante diversificada, o café e a cana-de-açúcar foram os grandes responsáveis pelo crescimento e dinamização da região.

Em 1842 a Câmara municipal teve papel efetivo na Revolução Liberal e na década de 1870 suas elites organizaram a "Convenção Republicana de Itu" da qual surgiu o Partido Republicano Paulista (HOLANDA, 1997 apud LOPES, 2009:32).

Não obstante a penetração da cultura iluminista, a cidade era urbanisticamente escorada pelas torres das igrejas, a "Roma Brasileira", tornou uma "legendária terra", graças ao casario branco, às campinas verdes e às torres das igrejas:

A nota alegre do casario branco, que se espalha pelo doce acclive da cidade, o pittoresco das campinas que se extendem em derredor, cingindoa entre os suaves matizes de tons esmeraldinos; essas torres magnificas que se levantam, veneraveis, impondo-se à contemplação de todo um povo, e que, pelos braços da cruz, apontam a vastidão do horizonte, ao mesmo tempo que nos monstram (sic), para o alto, com religioso carinho, o azul infinito do céu... [...] era nesta formosa cidade, ornada com esses monumentos symbolisadores da fé christã, e afamada pelas tradições 
inapagaveis da crença do seu povo, que eu vinha apresentar-me como paranympho aos primeiros bachareis em letras... (PORCHAT, 1904)

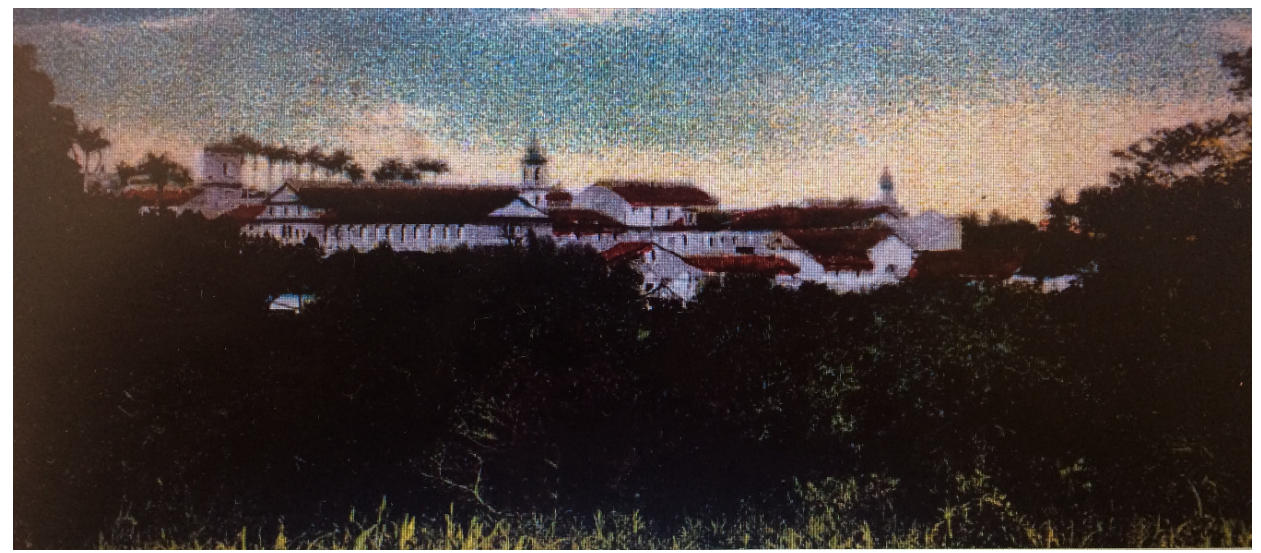

Figura 8: Cartão-postal com vista do Collegio S.Luiz, 1912

A configuração urbanística ituana estava alicerçada nas irmandades religiosas e congregações que, ao dialogarem com os grupos locais, neutralizavam o poder da Santa Sé e, desse modo, se aproximavam das diretrizes do iluminismo pombalino. Há que se lembrar que o iluminismo negava a tradição e a autoridade, e se contrapunha à institucionalização da religião, aos dogmas, ritos e preceitos, mas não necessariamente à religião. (COMBLIN, 1968)

O não reconhecimento da tradição e da autoridade da instituição religiosa é configurado pela laicização da cultura religiosa, de modo a diluir a fronteira entre clero e leigo/elite letrada. Foi o que ocorreu no "catolicismo iluminista" que procurava "conciliar o pensamento filosófico da ilustração com as crenças tradicionais do catolicismo", privilegiando a convivência entre clero e leigo, e atualizando "o pensamento filosófico e científico no sentido de inseri-lo na modernidade"(WERNET, 1998:47). Nesse sentido, era necessário neutralizar a autoridade pontifícia que, por não reconhecer a independência política do Brasil, sustentava a opressão colonial. Era necessário apartar as antigas ordens monásticas que atravancavam o processo de modernização do país e, conforme defendiam os bachareis da Academia de Direito, colocar a disciplina 
eclesiástica sob o controle das Igrejas locais. Em 1834 chegou-se a esboçar uma constituição eclesiástica, visando à extinção do celibato e à "adaptação do clero e da instituição católica às exigências dos tempos e dos lugares" (AZZI, 2005).

Se em São Paulo fermentava a cultura anticlerical ventilada pela Academia, em Itu a atmosfera não era diferente. Por ocasião da preparação do primeiro texto constitucional do país, algumas personalidades de projeção social ituanas propuseram como emenda a inserção da reforma eclesiástica. Malogrado o intento de aprovar o projeto em âmbito nacional, o padre ituano Antonio Feijó ainda se dedicou à sua discussão em nível provincial. (WERNET, 1987)

A vocação liberal da cidade, a cultura anticlerical, a concentração de corporações leigas e a sobreposição dos personagens de alta representatividade econômica e social à autoridade eclesiástica estavam em desalinho com as orientações da Santa Sé que orientava "sua artilharia contra a sociedade burguesa em afirmação", com base na concepção tridentina de que a Igreja "devia organizar-se de forma paralela ao Estado". (AZZI, 2005)

Os jesuítas ultramontanos fariam frente ao catolicismo liberal com o projeto de [contra]reforma do catolicismo e o processo de reconhecimento da autoridade papal como única fonte de poder justificando a ideia de subordinação da razão à fé, da filosofia à teologia e da ordem natural à sobrenatural. 


\section{1 - A retomada educacional dos jesuítas no Brasil do século XIX - tarefa doutrinária e [contra]reformista}

A conjuntura sociopolítica da primeira metade do século XIX propiciou o retorno dos jesuítas ao Brasil e a subsequente instalação do colégio masculino em Itu sob o modelo ultramontano de educação que havia sido implementado com a criação do Seminário Episcopal e do colégio feminino ${ }^{45}$. Os caminhos trilhados pelo grupo foram lentos e paulatinos no intuito de alcançar seus ideais doutrinários e frear os avanços do liberalismo e da modernidade.

O Censo de 1872 acusava a presença de 282 padres seculares, em uma proporção de um padre para cada 2948 habitantes na diocese da cidade de São Paulo. O reduzido número de clérigos, dentro da perspectiva reformadora do catolicismo que fazia do padre a figura central da administração eclesiástica, estava associado a outros problemas locais relatados ao papa em 1876 por Dom Lino Deodato (LEVA, 2014). Entre eles, o bispo citava o veto imperial à admissão de noviços pelas ordens religiosas, o que impedia a formação religiosa de jovens que pudessem professar em conventos, e o regime de padroado no qual os rendimentos dos padres eram providos pelo rei, que, desse modo, assumia o direito de nomeação de bispos e padres.

Além do baixo índice numérico de clérigos, Dom Lino denunciava a insuficiência da formação espiritual e intelectual e a escassez de senso pastoral dos clérigos seculares nacionais e estrangeiros, fatores que, aliados à presença de protestantes de imigração (os ingleses, em particular) na diocese e a forte presença de liberais e maçons nas confrarias e irmandades, tornavam impeditiva a realização do projeto reformador do catolicismo em São Paulo.

Para resolver a pendência no número de clérigos e suprir a "carência do clero nacional", Dom Lino investiu na entrada do clero estrangeiro, promovendo a vinda de 38

\footnotetext{
${ }^{45} \mathrm{Em} 1859$, foi inaugurado em Itu o Colégio Nossa Senhora do Patrocínio para meninas, sob a responsabilidade das irmãs de São José.
} 
ordens e congregações para o Brasil, com o fim específico de europeizar e romanizar o clero (WERNET 1987:185).

As dificuldades encontradas por Dom Lino, ao menos no que tange o arranjo numérico de clérigos, parece não se repetirem no município ituano o qual, desde o começo do século XIX, passava ao largo da ausência de padres. A considerar a relação numérica entre número de habitantes e de padres, a sua situação era bem outra já no início do século. Já em 1813, Itu contava com 5674 habitantes e tinha um clero numeroso: 38 padres, entre eles 33 seculares e 5 regulares (WERNET,1987:41). Esse quadro permite o estabelecimento da proporção de um padre para cada 150 habitantes, configuração bastante diferente daquela indicada para a diocese de São Paulo em 1872. Além disso, a cidade ituana reunia diferentes ordens religiosas.

As irmandades, associações que reuniam leigos em torno da devoção de um santo para a promoção de atividades religiosas e de caráter social (ex. assistência aos doentes, visita aos prisioneiros, compra de carta de alforria e proteção contra maus-tratos dos senhores) estavam presentes no município ituano desde o período colonial: Ordem Terceira de S. Francisco (1697), Nossa Senhora do Carmo (1716), S. Benedito (1710), Nossa Senhora das Dores (1788), Santíssimo Sacramento (1795) (NARDY FILHO,1999) ${ }^{46}$. A concentração de tantas ordens religiosas em Itu e a sua influência na política local levaram o Imperador D. Pedro II a chamá-la de "Roma Brasileira":

Fidelíssima pelo patriotismo e pela prova de fidelidade de seus filhos ao seu então Augusto Príncipe Regente. Roma Brasileira e Cidade Levítica, pela magnificência e suntuosidade de seus templos, pela pompa e renome de suas solenidades religiosas, pela piedade e firmeza na fé demonstrada por seus filhos. (NARDY FILHO, 1999:15)

Os números e o depoimento do monarca são reveladores do fato de que a cidade ituana não sofria do mal de carência clerical, chave usada por Dom Lino para promover a entrada das ordens religiosas europeias que aportaram na diocese paulista nos anos

${ }^{46}$ Cf: NARDY FILHO, Francisco. Cidade de Itu, vol.1, 1a parte, 1999. 
finais do Império e nas primeiras décadas da República. Acrescente-se ainda a existência desde as primeiras décadas do século XIX da Congregação dos Padres do Patrocínio, em que se reuniam padres como Jesuíno do Monte Carmelo, Diogo Antonio Feijó e Antonio Joaquim de Melo cuja convicção era a de que os sacerdotes deveriam ser "sobretudo educadores, formadores e moralizadores do povo" (WERNET, 1987:46), de que surgiu a convicção da necessidade de renovação e moralização do clero.

Entretanto esse grupo de padre renovadores se desfez com o falecimento do padre Monte Carmelo e com o envolvimento de Diogo Feijó na política provincial e nacional, o qual, coerentemente com sua formação, procurava "realizar uma reforma eclesiástica nacional. A conciliação do "pensamento filosófico da ilustração com as crenças tradicionais do catolicismo" (ibid,1987:47) que caracterizava o catolicismo iluminista exigia a contemporização do autoritarismo da Santa Sé. Os dogmas do catolicismo foram declinados para dar vazão às verdades originárias da razão, à liberdade de pensamento e à secularização de costumes.

Enquadrado pelo plano religioso, o terceiro padre, Antônio Joaquim de Melo, deu continuidade ao projeto de reforma eclesiástica, porém, em uma guinada, abandonou o plano dos padres reformadores ilustrados e, inexplicavelmente (ibid,1987:47) abraçou a proposta conservadora ${ }^{47}$. O fato é que enquanto Diogo Feijó lutava para aprovar na Câmara dos Deputados o projeto da reforma eclesiástica pelo viés liberal, o seu antigo companheiro de discussões filosóficas e teológicas se opôs declaradamente à Revolução Liberal de 1842, em defesa do princípio da autoridade, o que lhe rendeu a nomeação episcopal pelo Imperador (1847).

A Monarquia cuidava para que ideias liberais não prosperassem e, nesse sentido, procurou encaminhar suas ações para a continuidade e a tradição:

\footnotetext{
${ }^{47}$ Wernet (op.cit:48) discute que o encaminhamento do padre Antônio Joaquim de Melo para o lado conservador seja justificado talvez pelo contato com pessoas e leituras de tendência ultramontana, pela expressão de um ambiente peculiar de uma sociedade agrária, hierarquizada e escravista na qual ideias conservadoras, monarquistas e valores tradicionais parecem mais lógicos do que argumentos filosóficos racionais. Talvez, ainda, a existência de outras figuras no ambiente clerical de Itu, dos quais não se tem conhecimento.
} 
D. Pedro II e os seus principais conselheiros procuraram estabelecer fundamentos sólidos (...), e para tal finalidade, entre outras medidas, nomearam bispos que correspondiam à tendência conservadora e monarquista, para contrabalançar movimentos e correntes que se inspiravam em ideias liberais e radicais, e até republicanas. A corajosa defesa do princípio de autoridade, em plena Revolução Liberal de 1842, em Itu, um dos núcleos do movimento revolucionário, chegou ao conhecimento do Imperador e muito pesou para a indicação de Antônio Joaquim de Melo para bispo de São Paulo... (WERNET, 1987:52)

A nomeação de Dom Antônio Joaquim de Melo se justificava pelo fato de o padre ser um defensor da ordem estabelecida. Antiliberal, antimoderno e autoritário, durante 0 movimento liberal de 1842, tomando partido da monarquia e do imperador, o que the valeu a gestão episcopal paulista. (MANOEL,1996)

O agora bispo D. Antonio Joaquim de Melo, seguindo as diretrizes do papa Pio IX, colocou em ação o projeto de reforma do catolicismo, procurando afastar de vez o "catolicismo iluminista", que privilegiava o diálogo entre as crenças tradicionais e o pensamento filosófico da ilustração, ou seja, o entendimento e a convivência entre o clero e a elite letrada (WERNET, 1987). O catolicismo ultramontano vinha afastar essa prática religiosa que considerava "sincrética, supersticiosa e incontrolável" (AUGUSTO, 2005:268) e higienizar a sociedade, colocando-a nos trilhos da ordem civilizada.

Em oposição ao Estado liberal e republicano, adotava-se a ideia da Igreja Universal, com sede em Roma, e, como corolário, a entronização do poder papal. A autoridade do Papa passava a ser considerada absoluta, única e infalível, como o proclamou o concílio Ecumênico do Vaticano em 1871 (FAUSTINO, 1991). Para isso, o bispo $D$. Antonio convocou grupos europeus para resguardarem a educação dos jovens e dos futuros padres brasileiros consolidando um planejamento da Igreja Católica que pretendia a recristianização da sociedade.

A formação dos padres, a educação dos jovens e das mulheres era uma das vias adotadas pelo catolicismo ultramontano que visava a ilustração e moralização do clero, 
segundo as diretrizes romanas que propugnavam a universalidade da Igreja romana e a centralidade e infalibilidade do poder papal. É nesse sentido que Dom Antônio promove ações no âmbito da formação dos jovens por meio da abertura do Seminário Episcopal e de colégios católicos geridos por religiosos europeus, de formação ultramontana:

Portador de um discurso antiliberal, antimoderno e monarquista, seu programa contou com o apoio de Ordens e Congregações europeias como: os padres capuchinhos de Sabóia, que se incumbiram do Seminário Episcopal, e a Congregação das Irmãs de São José Chamberry, que fundaram o Colégio Nossa Senhora do Patrocínio em Itu, dedicado à instrução feminina. Ambos, ligados ao jesuitismo e ao ultramontanismo, estavam incumbidos da preparação intelectual de seminaristas, alunos e moças, através da doutrinação, da introdução de novas formas de práticas e devoções religiosas. Constituíram-se nos alicerces sobre os quais se reconstruiria uma sociedade católica, ordeira, disciplinada, hierarquizada, moralizadora, antimoderna, antiliberal, postulada pela lgreja. (GAETA, 1991)

O Seminário Episcopal de São Paulo seria responsável pela formação do clero dentro das diretrizes traçadas pelo ultramontanismo, de forma a marginalizar e desconstituir o catolicismo iluminista que se organizava por meio de concílios e sínodos de âmbito regional ou nacional (WERNET, 1985:2).

Já a fundação do Colégio Nossa Senhora do Patrocínio (1859) seria uma forma de propagar no âmbito familiar a cultura ultramontana que propugnava a fidelidade ao papa e condenava o racionalismo, o positivismo, o liberalismo, o socialismo e o comunismo, bem como depreciava a liberdade de religião e de pensamento e via com maus olhos a separação entre a Igreja e o Estado (FAUSTINO, 1991). Nesse sentido, o projeto episcopal visava ao fortalecimento da "instituição eclesiástica como um poder político paralelo ao Estado" (AZZI, 2005:395).

A abertura do colégio feminino em Itu foi uma estratégia para agir no fulcro da família no processo de recristianização da sociedade, segundo as diretrizes romanas. 
Apesar do discurso conservador e antiliberal em uma cidade governada por uma elite liberal, as irmãs do colégio do Patrocínio conseguiram ampla adesão das famílias locais e puderam, por meio da figura da mulher, agir na esfera familiar para atingir a sociedade como um todo.

Assim como o fez com o colégio do Patrocínio, D. Antônio Joaquim de Melo convocou grupos europeus para resguardarem a educação dos jovens e dos futuros padres brasileiros consolidando um planejamento da Igreja Católica que pretendia a recristianização da sociedade. Tanto a educação dos jovens, a formação dos padres, quanto a introdução de novas práticas devocionais eram o caminho encontrado pelo catolicismo ultramontano que ganhava força em São Paulo.

A visão de mundo ultramontana coadunava com uma sociedade oligárquica monárquica, escravocrata e patriarcal existente em São Paulo: "essa afirmação do catolicismo romanizado correspondia também aos anseios da burguesia agrária paulista, desejosa de pautar-se pelos valores civilizatórios europeus" (AZZI, 2005:395). Apesar da oposição dos defensores da política liberal que intencionavam, entre outras coisas, a laicização do ensino, o alinhamento entre os ideais católicos reformistas e os oligárquicos proporcionou a entrada das ordens religiosas ultramontanas e a fixação dos colégios católicos.

É nessa atmosfera que, no bispado de Dom Sebastião Pinto do Rego, sucessor de D. Antônio e predecessor de D. Lino, se dá o ingresso camuflado (AZZI, 2005) de jesuítas na cidade que havia exonerado de suas funções o padre ituano José de Campos Lara e os noviços da Companhia, Miguel e Ignácio, por ocasião da expulsão dos jesuítas do reino lusitano e de sua colônia brasileira em 1759.

O mito fundador do Colégio São Luiz está associado ao providencial encontro no navio Guyenne que partira de Bordeaux para o Brasil em 1863 entre o padre Razzini que se dirigia a Florianópolis e o padre Anthelmo Gold, capelão do Colégio feminino São José de Itu. No navio os dois padres teriam dado início ao projeto de criação de um colégio masculino e entabulado sobre o reingresso dos jesuítas na cidade de Itu: 
No correr das longas praticas, e com as quais iam entrecortando o enfado da vida monotona dos navegantes, raiou no espirito do Padre Anthelmo Gond a ideia de um colégio de meninos em Itu, e, refletindo-a na mente do Pe. Razzini, convidou-o a desembarcar em sua derrota para o sul do Brasil, na cidade de Santos, subir a serra e vir a Itu para tratarem juntos da exequibilidade dessa idéia, emquanto êle, precedendo-o em sua viagem, iria preparar os animos para esse cometimento.(COSTA, 1906:12)

Em 1864 reinstaurava-se a presença jesuítica em Itu com a chegada de cinco jesuítas no Convento dos Franciscanos. Traziam na bagagem as rígidas imposições do catolicismo de Pio IX. Apesar da articulação entre os jesuítas e do apoio do vigário da cidade, as negociações junto à Inspetoria de Instrução Pública e à Presidência da Província para a abertura de um colégio na cidade encontraram empecilhos na esfera do governo provincial, que, dominado por liberais, ao tomar conhecimento de que o corpo docente seria formado por jesuítas, e temendo a influência que esses padres pudessem desenvolver sobre a cidade, procurou dificultar a liberação da licença para a fundação do Colégio (LOPES, 2009).

A oposição se fazia pela não liberação da licença à fundação do colégio pois "os jesuítas eram, então, a principal força de defesa do ultramontanismo em todo o mundo" (WERNET, 2005:1232).

Sem o apoio governamental, os jesuítas apelaram para a população local, procurando conquistar a adesão dos ituanos ao projeto jesuítico do estabelecimento de ensino. Obtiveram sucesso em 1867 com o investimento de D. Pedro II na reformulação educacional, fazendo frente aos colégios laicos que começam a se estabelecer na região e com a ajuda de uma parcela da oligarquia ituana, que tomou a dianteira para que 0 colégio fosse concretizado:

Recebido o Dr. Prado ${ }^{48}$ pelo Inspetor em sua sala, disse ao Dr. Diogo: assina ou não assina a licença para abertura do Colegio em Itu?! O

\footnotetext{
${ }^{48}$ Trata-se do Dr. Martinico Prado (1843 - 1906), político e empresário do café.
} 
Inspetor, que muito bem conhecia o genio do Dr. Martinico, vendo sua atitude resoluta, todo tremulo pegou da pena e deu o despacho. Logo saiu o Dr. Prado e entregou ao Sr. Antonio A. Fonseca a licença desejada, findando deste modo com feliz despacho a comedia que por tanto tempo conservava suspensos os espiritos dos Ituanos honestos. (COSTA, 1906)

A inauguração ocorreu no dia 12 de maio de 1867, no antigo Convento de São Francisco, recebendo inicialmente 53 alunos. Em pouco tempo, os jesuítas contaram com grande adesão dos ituanos no financiamento da construção de suas novas instalações, pois o edifício dos franciscanos se mostrava impróprio para as atividades educacionais devido ao aumento do número de inscritos. Os jesuítas construíram o colégio, cuja primeira fase foi inaugurada em 1872, no antigo Seminário de Nossa Senhora do Bom Conselho, erigido décadas antes pelo jesuíta José de Campos Lara e então recobrado, via doação, pelo padre José Galvão de Barros França (LOPES, 2009). A contribuição dos ituanos para a construção do novo colégio fica registrada pelo professor do Colégio São Luís e mestre-capela na igreja Matriz de Itu:

Os bons Ituanos, amigos do progresso verdadeiro e solido de sua terra, sempre mostraram-se afeiçoados e reconhecidos aos Padres Jesuitas, cuja prova aí está no arquivo do Colégio de um documento e de uma lista onde se pode ver mais de cinquenta nomes de pessoas que concorreram com sua oferta para as despezas no principio do Colégio. (COSTA, 1906:19)

Um acordo com a Irmandade da Boa Morte garantia o uso comum da igreja anexa em cuja torre em 1891 foi instalado o sino presenteado pelo papa ultramontano Leão XIII, o qual simbolizava a aliança entre os jesuítas e o processo de romanização da Igreja. Apesar da aversão dos ultramontanos radicais à modernidade e à República, a aliança com os parâmetros pontifícios recobrando a autoridade papal em franco afrontamento aos ideais liberais não impediu que o templo, concluído já no governo republicano, trouxesse o brasão da República ao centro de seu frontão, talvez como forma de 
reconhecimento à Constituinte por ter retirado do texto constitucional de 1891 o artigo que determinava a expulsão do país da Companhia de Jesus (LOPES, 2009).

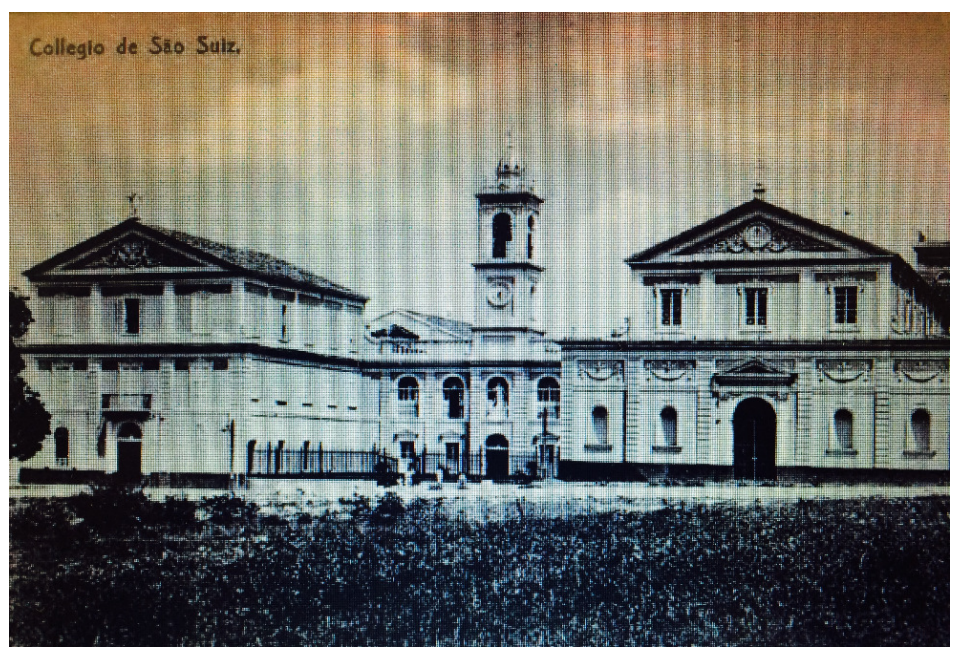

Figura 9: Cartão-postal do Collegio de S.Luiz, 1909

Ressalte-se que os liberais não conseguiram perpetrar em Itu nenhuma iniciativa educacional própria ou de orientação protestante (CAVALHEIRO, 2001) e que, a partir da década de 1870, as lideranças católicas paulistas se dobraram à política ultramontana, com a construção do Seminário Episcopal que fazia frente ao catolicismo liberal e em cujos bancos estudaram alguns acadêmicos defensores da instituição católica, como João Mendes de Almeida Júnior. A defesa se fazia por meio dos periódicos católicos criados na Academia de Direito: O Católico (1876), fundado pelos acadêmicos Benedito Filadelfo de Castro e Leão Bourroul, $A$ Sentinela, dirigido por João Mendes de Almeida Júnior, $A$ Reação, $A$ Vanguarda e $O$ Monitor Católico. Nesses periódicos, Eduardo da Silva Prado (1895) escreveu as Conferências Anchietanas em que fazia elogio aos membros da Companhia de Jesus, atribuindo-lhes a responsabilidade pela formação social brasileira (AZZI, 2005). À cultura católica que se impunha por meio de vários órgãos, soma-se a bandeira republicana da educação escolar. 


\section{2 - Colégio São Luís de Gonzaga - rotina escolar e matérias ensinadas}

Embora não fosse uma novidade na Europa, a fórmula do Internato foi introduzida no Brasil a partir de Itu por ocasião da vinda do colégio feminino e do colégio jesuítico e constituia-se em uma estratégia para a formação e controle das mentalidades. A vigilância do tempo e das ações dos jovens era uma maneira de estabelecer um controle sobre a própria circulação das ideias, criando um universo à parte, com códigos disciplinares rígidos e linguagem própria. Os alunos eram banidos do convívio com suas famílias, as leituras eram controladas e a troca de correspondências e a entrada de pessoas não eram autorizadas. O internato também reforçava o caráter elitista da instituição, pois criava uma diferenciação social ao ser frequentado apenas pelos filhos das famílias ricas. A escola externa ou o orfanato atendiam às demais esferas sociais.

Além da doutrinação religiosa recebida em sala de aula, os alunos eram envolvidos em práticas diárias de religiosidade, como as orações, os atos litúrgicos, os festejos comemorativos. Retirados de uma vida cotidiana junto a suas famílias, os alunos eram expostos às normas e aos preceitos organizados pelo ultramontanismo, que concretizava seu projeto de reconstrução da sociedade. O ultramontanismo pregava o providencialismo, que correspondia à visão de que Deus é o verdadeiro sujeito e protagonista da história, sendo que tudo deve ser atribuído à providência divina. Assim, o homem seria apenas seu objeto, produzindo no homem um menosprezo da vida terrestre, um conformismo e uma resignação. Essa percepção de coisas era fundamental para que os alunos se resignassem e se mantivessem reclusos na instituição.

De acordo com as normas do Ratio Studiorum, o cotidiano dentro da instituição consistia em aulas no período da manhã, com explicações do professor, exercícios de repetição e recitação.

A língua de comunicação nas cartas e nos "livros-diário" dos professores era o italiano. Toda anotação feita sobre os alunos nos livros, desde as aptidões especiais em algum instrumento musical, como o piano; até problemas de saúde e dentários eram 
feitas nessa língua. Nos atos litúrgicos e festejos, a língua empregada também era o Latim. A língua falada nos corredores e nas aulas era a vernacular.

No "prospecto" lançado por ocasião da abertura do Colégio, elaborado pela Typografia J.Leme de O. Cesar, em 1865, e assinado pelo padre jesuíta T. Razzini, o fim do Colégio era a educação religiosa intelectual e civil da mocidade e que, por parte do Colégio, era empregado todo o desvelo para que os alunos aproveitassem a educação nesses três âmbitos.

Admitiam-se alunos internos que principiavam sua educação "pública", não podendo ser menores de 7 anos, nem maiores de 14 anos. Deveriam ser destinados a cursar inteiramente o curso de estudos exigidos como preparatórios para as academias do Império. Não era permitido o ingresso de alunos que sofressem de alguma moléstia, de escravos e de alunos "despedidos" de outros colégios.

Os estudos dividiam-se em primários e secundários. O curso primário constava de leitura, caligrafia, doutrina cristã, gramática portuguesa, história sagrada, preliminares de geografia, primeiras operações de aritmética. Já o curso secundário abrangia o Latim, Grego, Francês, aritmética, história, geografia, retórica, filosofia racional, moral, matemática e física.

A pensão para os internos era de 300:000 (trezentos mil réis) pagos por trimestres antecipados, na ocasião do ingresso, juntamente com a taxa da primeira matrícula em uma vez de 30:000 (trinta mil réis). Na pensão estavam compreendidos os alimentos, o ensino, a lavagem de roupa, os gastos de luz, o serviço doméstico. Todas as outras despesas ficavam a cargo das famílias. Os alunos externos, que eram poucos, pagavam 5:000 mil reis mensais.

Cada aluno deveria trazer um enxoval composto de colchão, travesseiro e bacia; toalhas, cobertores, lençóis e fronhas; escovas de roupa, dentes e cabelo. O uniforme constava de uma sobrecasaca preta, uma calça, colete branco, gravata branca, botina e chapéu de copa alta. Havia também o uniforme de passeio, em tom mais claro. Para o 
banho, eram necessários dois calções, pois os alunos não podiam se despir completamente. Vale ressaltar, nesse ponto, que a retirada dos alunos do seio familiar significava a sua retirada também do ambiente social, a escola também proporcionava 0 apagamento do corpo ao impor o uso de ceroulas para o banho ou ainda não fazer qualquer menção a aulas de educação física. A figura abaixo apresenta o dormitório coletivo dos alunos internos. Atente para a organização dos itens em cima das camas e para os objetos de higiene pessoal:

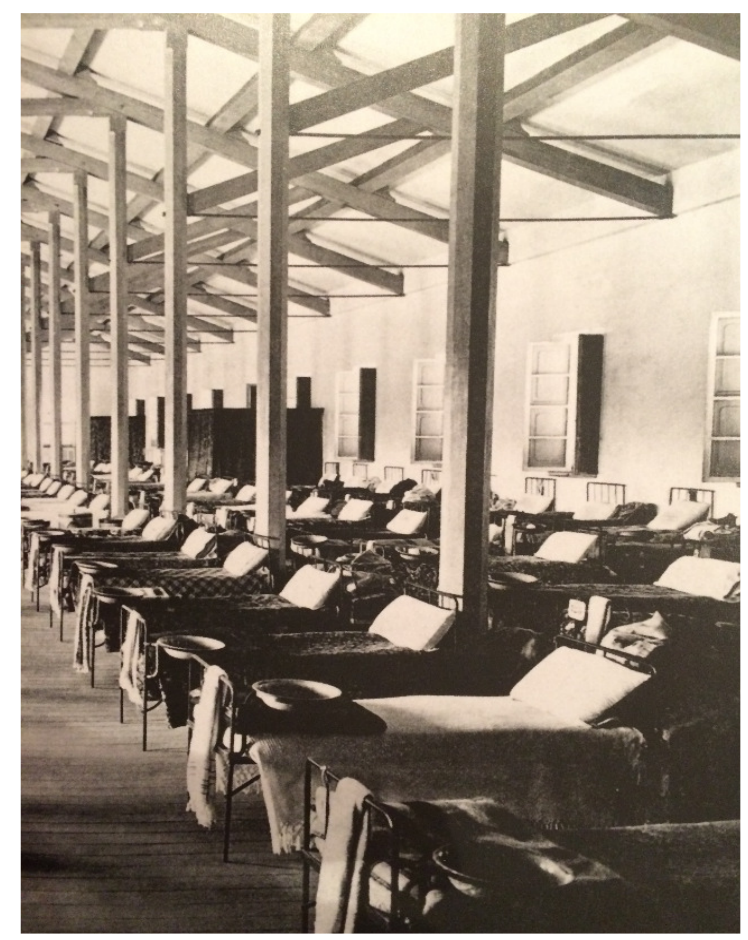

Figura 10: Dormitório dos alunos, Itu, 1903

O programa do Ratio Studiorum era dividido em 6 anos de estudos. Essa seriação era composta de uma série preparatória, chamada de instrução primária. No programa seriado composto pela Igreja para organizar o ensino nos colégios jesuíticos, o qual era denominado de Programma de Ensino para os Collegios da Companhia de Jesus no Imperio do Brasil, apresentava-se todo o conteúdo estudado em cada disciplina e, em alguns casos, as obras adotadas. A estruturação dos cursos de instrução primária e secundária era a seguinte: 
Instrução Primária (curso de 1 ano):

Português, Caligrafia, Aritmética, História e Religião.

Instrução Secundária (curso de 5 anos):

$1^{\circ}$ ano: Latim, Português, Francês, História, Geografia, Aritmética, Religião;

$2^{\circ}$ ano: Latim, Português, Francês, História, Geografia, Aritmética;

$3^{\circ}$ ano: Latim, Português, Francês, Inglês, História, Geografia, Matemática, Religião;

$4^{\circ}$ ano: Latim, Português, Inglês, História, Matemática, Religião;

$5^{\circ}$ ano: Latim, Português, Inglês, História, Matemática, Religião.

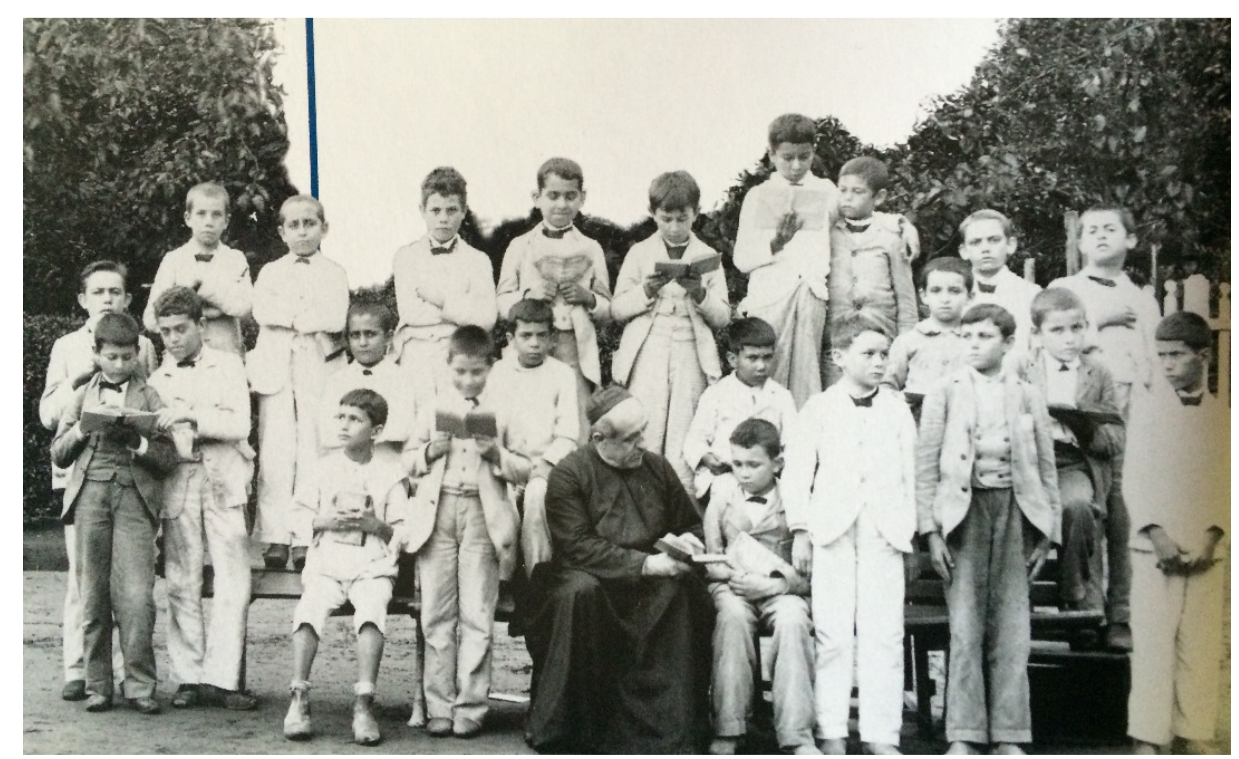

Figura 11: Alunos de Primeiras Letras - P.Soriani, 1899

Na figura acima, podemos observar os alunos da série inicial, o curso de Primeiras Letras do Padre Soriani. A postura dos alunos denota o objetivo maior da série, a aprendizagem e prática da leitura. O padre se coloca como um condutor ativo desse objetivo ao segurar o livro e instruir o aluno acerca do modo de se proceder. Curiosamente, os alunos não apresentam uma postura formal, rígida, assim como o professor também não. Tal configuração pode sugerir a tentativa de mostrar a relação familiar, agradável, de ajuda mútua que os alunos mantinham entre si e com os padres 
jesuítas, bem como, a ideia de que são crianças representantes de um grupo de "estabelecidos" 49 .

A organização curricular do Colégio mostra como os conteúdos ensinados eram voltados para o ensino da religião cristã, mesmo nas matérias de línguas ou história. Em Língua Portuguesa, além do livro de gramática, havia ainda o "caderno de textos", contendo trechos e passagens de textos de autores que serviam de exemplos do bom escrever. Os textos retratavam episódios da vida de personagens da História Antiga entre outros, e tinham por finalidade exemplificar a moral criada e assumida pela Igreja Católica.

No curso de Instrução primária, o estudo de Língua Portuguesa compreendia leitura, gramática elementar, o estudo dos nomes, pronomes, adjetivos, verbos regulares e irregulares, preposições, conjunções e advérbios. Era utilizado o Manual Encyclopedico por Emílio Achilles Monteverde, editado em Lisboa, pela Imprensa Nacional.

Constante do "Programma de Ensino para os Collegios da Companhia de Jesus no imperio do Brasil", o Manual Encyclopédico para uso das escolas d'instrucção primaria, escrito por Emilio Achilles Monteverde, foi amplamente utilizado na série inicial de formação do Colégio ${ }^{50}$. A edição usada para no Ensino Primário corresponde à $8^{\mathbf{a}}$ edição revista e melhorada, impressa em Lisboa, em 1865, pela Imprensa Oficial, tendo sido aprovada pelo Conselho Geral D'Instrucção Publica. Esteve em circulação em Portugal e no Brasil por um longo período na segunda metade do século XIX e primeiras décadas do século XX, sendo distribuída no Rio de Janeiro pelas livrarias E.H. Laemmert e B.L.Garnier. O livro parece ter tido ampla aceituação tanto nas instituições escolares portuguesas, como brasileiras, pois, segundo o Diccionario Bibliographico Portugues, em 1865, foram publicados 40.000 exemplares e, para edição de 1870, 42.000 .

\footnotetext{
${ }^{49}$ Tomando como empréstimo o termo usado por Norbert Elias e John L. Scotson (2000 [1965]) para definir a configurações dos grupos de poder.

${ }^{50}$ O Manual teve sua primeira edição no Brasil em 1861.
} 
Na Instrução secundária, dividia-se o estudo de português em "discurso e sintaxe", Gramática "Aulete", para o $1^{\circ}$ ano; exercícios escritos - narrações, descrições para o 2ํㅜ preceitos de estilo epistolar, exercícios de cartas, no $3^{\circ}$; exercícios escritos conforme os preceitos de retórica, para o $4^{\circ}$ ano, e exercícios escritos conforme os preceitos de poética para o $5^{\circ}$ ano.

Convém ainda falar sobre o ensino de História, que consistia basicamente do ensino da "história católica", com aulas sobre o "antigo testamento desde a criação do mundo até a morte de Moisés", no ano da instrução primária; seguindo, na Instrução Secundária, da História sagrada do antigo testamento, desde a morte de Moisés, dividindo os anos a partir daí, com a História do Brasil, História antiga, História média e História moderna.

A matéria "religião" iniciava-se como um compêndio de catecismo, passando para explicações dos símbolos dos apóstolos, explicações de orações dominicais, explicações dos mandamentos de Deus e dos sacramentos e, ainda, a designação dada para o último ano de "noções da Igreja Católica".

\section{3 - Os anos em Itu e a formação da elite paulista}

Desde sua inauguração, os jesuítas dirigiram suas atividades educacionais ao atendimento da elite agrária local. Em sua Breve História do CSL, COSTA (1906:14) mostra que, da atividade de 40 anos do Colégio, a intenção fôra a formação dos alunos para as altas posições da sociedade:

E agora no correr destes 40 anos que aqui estão, que numero avultado dos discipyulos dos Padres Jesuitas, no parlamento, na magistratura, no exercito, na marinha, no comercio, na lavoura, na industria, nas belas artes, nas ordens sacras onde até bispos contamos! (...) Seriamos os maiores ingratos sinão reconhecessemos os inumeros beneficios que tem feito esse Padres ao nosso caro Brasil pela instrução civil e religiosa, 
sabendo aliar a fé com a ciência, e formando o caráter do homem conforme sua posição social. (COSTA, 1906:14)

A elite econômica ituana e de suas adjacências formou a clientela recebida pelo Colégio, embora ainda existam registros de alunos vindos de outras regiões do país. Segundo Cavalheiro (2001), as famílias que procuravam o colégio jesuítico buscavam uma formação "tradicional e exemplar a seus filhos". Essa elite, ansiando por um catolicismo ortodoxo, era composta por um pequeno grupo que reunia diversas categorias, desde proprietários de terra, de imóveis e de estabelecimentos comerciais, ou ligados ao cultivo da cana-de-açúcar e à plantação de café.

A lista de alunos aponta para 57 alunos internos e 9 externos. Entre eles, nomes conhecidos da oligarquia cafeeira e açucareira do interior paulista, como as famílias Almeida Prado, Barros, Ferraz da Luz, Ferraz Sampaio, Camargo, Pacheco, que se destacaram ou política ou como fazendeiros, banqueiros, empresários, médicos, advogados. Esses nomes que compuseram as primeiras listas de alunos geralmente eram herdeiros de núcleos endogâmicos, fechados dentro de um mesmo grupo familiar, construindo uma combinação de nomes, como Galvão de Almeida, Almeida Barros, Barros Cruz.

Os jesuítas mantiveram suas atividades por 50 anos na cidade e, no ano de 1917, procuram novo endereço para o Colégio, estabelecendo-se na cidade de São Paulo. Dois fatores contribuiram para a mudança. De um lado, as epidemias que assolaram o interior paulista no final do século XIX, vitimando professores e alunos, como pôde ser averiguado nos livros de registros de matrículas; por outro, a movimentação da própria clientela rumo à capital. A explosão demográfica da cidade de São Paulo51 iniciou-se na segunda metade do século XIX, sendo que, em 1870, São Paulo já contava com cerca de 20 mil habitantes, número que triplicaria em 1890.

\footnotetext{
${ }^{51}$ Ver Perosa, 2004:63.
} 
A mudança concretizou-se no ano de 1918. As instalações do recém fechado Gimnásio Anglo-Brasileiro, na Avenida Paulista, passou a ser o endereço do colégio, que manteve sua clientela vinda do interior e recebeu novos alunos da capital, incluindo o sistema de semi-internato ao já praticado sistema de externato.

O Colégio São Luís obteve receptividade da elite local, o que é observado pelo número de alunos, que chega a 600 alunos no ano de sua fixação em solo paulistano. $O$ livro "Collegio São Luís - Matrícula dos Alumnos 1917 - 1933" informa que a clientela passou a ser nova vizinhança da Avenida Paulista, entre os quais os estrangeiros que ocuparam a região. 


\section{CAPÍTULO 3 - A "REPETIÇÃO" COMO ESTRATÉGIA dA CONSTRUÇÃo dO IMAGINÁRIO JESUÍTICO}

\section{Introdução}

Um dos tópicos mais desenvolvidos nos discursos proferidos por personagens externos ao colégio acentua a atuação dos jesuítas no processo civilizatório regida pela disposição à sujeição, a qual instaura ações reflexivas que se conectam com o elo da cadeia jesuítica: padre Anchieta.

A repetição enquanto estratégia que desenvolve os aspectos centrais da condução tópica e estabelece conexão interfrástica é um mecanismo que auxilia na construção do texto por meio da formação de cadeias discursivas (MARCUSCHI,2006). Entendemos assim que a repetição, por reiterar a produção de segmentos textuais, é um sinalizador da produção de habitus e será tomada como objeto de estudo neste capítulo. Ressaltamos que, apesar de tocarmos em pontos da retórica, não objetivamos explorar as fases (inventio, dispositio, elocutio e actio), os gêneros (deliberativo, judiciário ou epidítico) e as provas do discurso, segundo a Arte Retórica. Exploraremos tão somente a repetição linguística como expediente da construção do imaginário e das práticas jesuíticas.

Esse capítulo se divide em três partes: 1. Dos discursos por ocasião da formatura dos bacharéis do Ginásio; 2. Dos panegíricos e 3. Do discurso ao cardeal Arcoverde.

\subsection{DOS DISCURSOS}

Assumimos que todo gênero discursivo constitui e é constituído por um conjunto de formas do ritual enunciativo. Pela perspectiva comunicacional, o gênero "discurso" se caracteriza por ser um texto escrito para ser transmitido oralmente, pressuposto necessário para entender as práticas que evidenciam o discurso religioso católico que, 
pautado na palavra oral, transmite a verdade das Escrituras. A fusão das estruturas comunicativas do gênero "discurso" com as estruturas do pensamento religioso jesuítico constrói o espaço enunciativo e o seu duplo, no qual transitam livremente as técnicas analógicas que instauram e atualizam a tradição, modo de organização dos jesuítas.

Apesar de o texto fundante do gênero "discurso" ter como suporte a escrita, ele, por ser transmitido oralmente, é ancorado por uma voz, instaurando mais uma homologia entre discurso e religião, pois esta se manifesta como Voz. O segredo da escrita é revelado pela voz. A revelação contida na voz do discurso histórico é dificultada pelo empecilho da recuperação dos traços prosódicos que a caracterizam. Entretanto, há uma voz que "habita a enunciação do texto" (MAINGUENEAU, 1997:46) constitutiva do gênero "discurso" e que engendra a revelação da verdade contida nos textos sagrados.

Nas práticas jesuíticas, o discurso é uma estratégia de exibição do aspecto público do culto e de tática de convencimento da cultura cristã. Nessa perspectiva, a invocação de autoridades é uma forma de legitimar suas práticas e disseminá-las pelos ouvintes. $O$ primeiro discurso, o de Reynaldo Porchat (1904), saúda um representante do governo estadual e federal; o segundo, o de Altino Arantes (1906), invoca a presença de um representante da esfera do governo federal; o terceiro, o de Carlos de Laet (1907), faz a indicação da presença de um representante da autoridade civil, sem definir a esfera de governo à qual pertence. Os discursos de Câmara Leal (1909), João Mendes de Almeida Júnior (1908) e Júlio Prestes (1910) não fazem menção à presença de nenhuma autoridade civil na formatura dos bacharéis, como sugere o quadro a seguir: 


\begin{tabular}{|c|c|c|c|c|c|c|}
\hline ORADOR & \multicolumn{6}{|c|}{ AUDITÓRIO } \\
\hline $\begin{array}{l}\text { REYNALDO } \\
\text { PORCHAT } \\
(1904)^{52}\end{array}$ & $\begin{array}{l}\text { Revm. } \\
\text { Padre } \\
\text { Reitor }\end{array}$ & \begin{tabular}{|l|} 
Exm. Sr. \\
Representante \\
do Governo \\
do Estado
\end{tabular} & $\begin{array}{l}\text { Exm. Sr. } \\
\text { Delegado } \\
\text { Fiscal do } \\
\text { Governo } \\
\text { Federal }\end{array}$ & & \begin{tabular}{|l} 
Exmas. \\
Senhoras, \\
Senhores
\end{tabular} & \\
\hline $\begin{array}{l}\text { ALTINO } \\
\text { ARANTES } \\
(1906)\end{array}$ & $\begin{array}{l}\text { Revmo. } \\
\text { Sr. Pe. } \\
\text { Reitor }\end{array}$ & & $\begin{array}{l}\text { Exmo. } \\
\text { Sr. } \\
\text { Delegado } \\
\text { Fiscal do } \\
\text { Governo } \\
\text { federal }\end{array}$ & & $\begin{array}{l}\text { Senhoras, } \\
\text { Meus } \\
\text { Senhores }\end{array}$ & \\
\hline $\begin{array}{l}\text { CARLOS DE } \\
\text { LAET(1907) }\end{array}$ & $\begin{array}{l}\text { Revmo. } \\
\text { Sr. } \\
\text { Reitor }\end{array}$ & \multicolumn{2}{|c|}{$\begin{array}{l}\text { Sr. Representante da } \\
\text { Autoridade Civil }\end{array}$} & $\begin{array}{l}\text { Revmos. } \\
\text { Srs. } \\
\text { Membros } \\
\text { do Clero }\end{array}$ & \begin{tabular}{|l} 
Exmas. \\
Senhoras, \\
Meus \\
Senhores
\end{tabular} & $\begin{array}{l}\text { Srs. } \\
\text { Bacharelandos }\end{array}$ \\
\hline $\begin{array}{l}\text { CÂMARA } \\
\text { LEAL } \\
\text { (1909) }\end{array}$ & $\begin{array}{l}\text { Revmo. } \\
\text { Snr. Pe. } \\
\text { Reitor }\end{array}$ & & & $\begin{array}{l}\text { Revmos. } \\
\text { Snrs. }\end{array}$ & $\begin{array}{l}\text { Exmas. } \\
\text { Snras. } \\
\text { Meus } \\
\text { Senhores }\end{array}$ & $\begin{array}{l}\text { Snrs. } \\
\text { Bachareis }\end{array}$ \\
\hline $\begin{array}{l}\text { JOÃO } \\
\text { MENDES } \\
(1908)\end{array}$ & & & & & \begin{tabular}{|l} 
Meus \\
Senhores
\end{tabular} & $\begin{array}{l}\text { "meus jovens } \\
\text { amigos" }\end{array}$ \\
\hline $\begin{array}{l}\text { JÚLIO } \\
\text { PRESTES } \\
(1910)\end{array}$ & & & & & & $\begin{array}{l}\text { Senhores } \\
\text { Bacharelandos }\end{array}$ \\
\hline
\end{tabular}

\footnotetext{
${ }^{52} \mathrm{~A}$ data entre parêntese refere-se ao ano em que o discurso foi proferido no Colégio S. Luiz.
} 
Do conjunto de textos examinados, detectamos nos discursos proferidos por oradores externos à comunidade jesuítica quatro tópicas que, por meio da repetição, recuperam e fortalecem o imaginário da Companhia: 1. a fundação mítica e legendária do colégio; 2. a expulsão e o retorno dos jesuítas; 3 . a solidez e a persistência jesuítica; 4. A idealização do jesuíta como libertador. Esse capítulo trata do imaginário jesuítico recuperado pela repetição textual, um dos traços da voz do "discurso".

\subsubsection{A fundação mítica e legendária do colégio}

O tópico relativo à fundação mítica do colégio é tratado pela repetição de marcadores textuais e de orações relativas que, em alguns casos, são entremeadas de orações subordinadas adverbiais finais. A completar a estratégia da repetição são usados outros meios como o uso do demonstrativo locativo que marca a progressão tópica e o uso dos reflexivos que acentua a disposição de sujeição e de submissão dos jesuítas às regras fixadas no Ratio ${ }^{53}$.

\subsubsection{A criação do cenário}

$\mathrm{Na}$ sequência abaixo, o quadro tópico "colégio" é indicado na abertura e no fechamento da unidade textual, com o marcador textual "foi assim que" e a forma quase espelhada "assim, foi que". Esse marcador coesivo tem a função de apelar para conhecimentos compartilhados - a fiscalização do colégio pelo orador, de modo a dar legitimidade à narrativa.

A partir de um supertópico "fiscalização do colégio", desencadeiam-se vários subtópicos (compreensão da obra de Loyola, admiração por Loyola, reconhecimento dos jesuítas, reconhecimento das ações jesuíticas, admiração e compreensão dos jesuítas, aprendizagem do método jesuítico), introduzidos pelo marcador "d'ahi", que pontua a obra de Loyola e seu desdobramento/espraiamento graças ao "reflexo da alma do santo

\footnotetext{
${ }^{53}$ Ver capítulo 1.
} 
a espalhar-se", e a ideia de completude dos jesuítas, marcada pela expressão "em tudo sempre cheios de bençams ou de esperanças".

O marcador textual "daí" tem a função de articular a estruturação tópica, pois é um conectivo que retoma o que foi dito anteriormente e anuncia o tópico seguinte. A repetição do marcador textual tem a função de garantir a centração e a organicidade textual, aparentemente quebrada pelas longas digressões introduzidas no texto usadas para particularizar as ações jesuíticas e dar sustentação à adesão do autor ao jesuitismo. Essas digressões, enquanto tópicos desviantes, afastam, porém a atenção do ouvinte do tópico central.

A repetição do marcador textual tem a função de criar sequenciação e encadeamento dos enunciados, dando continuidade à organização tópica, além de reestabelecer a coerência textual e a conexão do ouvinte desviada com as digressões:

FOI ASSIM QUE, n'uma manhã catasolada de oiro,

bati ás portas deste collegio e assumi a sua fiscalização.

D’AHI VEM a comprehensão que tenho da obra gigantesca de lgnacio de Loyola que, entre os erros que assignalavam o despedir da Renascença, despia a sua couraça guerreira, deixava a um canto a espada refulgente, esquecia os seus brazões de fidalgo, e, levantando uma cruz, fundava essa instituição que é um mundo de sabedoria e de amôr - a companhia de Jesús - para que ella operasse a regeneração da humanidade.

D’AHI a minha admiração pelo homem,

a minha veneração pelo sábio,

o meu amôr pelo santo.

D'AHI FOI QUE eu comecei a ver em cada jesuíta que a Historia me apresentava ou que a fortuna me dava a conhecer, um reflexo da alma do santo a espalhar-se no seu saber que illumina, na sua prudencia que acalma, no seu amôr que é unanime, na sua obediencia que é infinita, na sua cordura que é virgem, na sua bravura que é heroica, no seu caracter que é inexpugnavel!.

D’AHI FOI QUE acompanhei na jornada da Historia a historia dos jesuitas. 
Encontrei-os nos pulpitos da Europa combatendo com Luthero....

e vim revel-os na America...

É de vel-os, então, nos mil desdobramentos da vida!

Ahi, vamos encontral-os levantando a cruz, orando, convertendo, aconselhando, curando, ensinando, cultivando e edificando aquelles templos...

Vemol-os, então, á proa dos navios, ao leme das jangadas, á frente das bandeiras... por toda parte...

Vemol-os palmilhando as florestas, ajudando o lavrador a cultivar...

Arrostando perigos não sonhados, aos soes e aos temporaes, vemo-los ainda descobrindo a trahição das corredeiras ou lacerando as carnes nos espinhos, a encaminharem para a conquista e para a Victoria aquelles aventureiros bandeirantes...

Por isso em cada pagina de nossa historia, como em cada recanto do nosso território... nos vamos encontrar o signal do jesuíta que por alli passou....

ASSIM, aprendi a admiral-os em tudo: no estudo da vida ou dos astros, na poesia de

Deus ou das selvas, no banco da catechese ou no púlpito das cathedras, no perdão ou no soffrimento, em tudo, em tudo sempre cheios de bençams ou de esperanças.

ASSIM, FOI QUE eu comecei a comprehender todo poder e toda grandeza do jesuíta e

ver que aquelles roupetas tão injuriados nos autores livres serviram n'outros tempos de sombra de ternura entre as soalheiras e as febres e servem hoje, n'uma sociedade americanisada que os falsos credos dissolvem e os interesses congregam, de centro de attração e ponto de partida para uma vida melhor.

\section{E FOI AQUI NESTE COLLEGIO}

[que eu vim aprender no seu methodo de ensino, estudar a sua vida, admirar a sua dedicação e a sua tenacidade. (J. PRESTES)

A repetição do marcador textual "d'haí", que preserva o significado espaçotemporal, auxilia, juntamente com a reiteração de verbos perceptivos, a referendar o processo de fiscalização operado pelo orador junto ao colégio. Entretanto, trata-se de uma ilusão de ótica, pois as cenas colocadas à vista (por exemplo, o combate com 
Lutero, o jesuíta nos navios e nas florestas) não foram testemunhadas pelo orador e, portanto, não podiam ser objeto de fiscalização.

A única observação objetiva do fiscal é que ele veio "aprender no seu methodo de ensino", ou seja, reconstruiu o cenário pela cartilha jesuítica, absorvendo a sintaxe e, por meio dela, a figuração do Julgamento final, contida no livro Apocalipse: "Então vi um novo céu e uma nova terra. [...] E vi a Cidade Santa, a nova Jerusalém [...] Ouvi uma voz forte que vinha do trono a qual disse: Agora a morada de Deus está entre os seres humanos!"

Nesse sentido, o fiscal não constatou, mas assimilou o imaginário que os jesuítas construíram de si mesmos e, por meio do marcador "foi assim que"/ "assim foi que" o tornou a-histórico, contribuindo para a fundação mítica da instituição na qual atuam: o colégio.

\subsubsection{A fixação do tópico discursivo}

A imagem mítica e legendária do colégio jesuítico é projetada pela repetição das estruturas relativas com função de sujeito, que remete sempre a um local. Partindo do

mais amplo estreita o foco para o colégio de S. Luiz (Itu, Igreja de Nossa Senhora do Patrocínio, a velha matriz, este edifício):

Ao receber, hontem, os primeiros bafejos da brisa YTUANA, [...]

senti, maravilhado, uma impressão dulcíssima

ao meditar sobre a missão que me trazia a ESTA LEGENDARIA TERRA.

A nota alegre do casario branco,

[que se espalha pelo dôce acclive da cidade,

o pittoresco das campinas

[que se extendem em derredor[...]

essas torres magníficas

[que se levantam, veneráveis, [...]

[e que [..] apontam a vastidão do horizonte

[que nos mostram [..] o azul infinito do céo 
LÁ, assentada elegantemente em um dos flancos da collina, A EGREJA DE NOSSA SENHORA DO PATROCINIO

a guardar, amoravel, junto dos santos

[que habitam os seus altares,

um bando innocente de creaturinhas tenras [...]

[que as mães confiam áquella casa de amor e religião

A VELHA MATRIZ

[em cujas abóbadas já resoaram cantos de gerações antigas,

[e em cuja nave se dobraram joelhos de personagens nobres

varões eminentíssimos,

[que honraram sempre o nome glorioso da terra paulista;

AQUI [...] ESTE GRANDE EDIFICO

[onde vivem estas crianças

dedicados mestres,

[que são ministros de Deus

primeiros bacharéis em letras

[que saem deste conceituado Gymnasio

[onde pompeiam os clarões da mesma crença, refulge intensamente a mesma fé,

[que é a auréola a circumdar de luz o grato renome do torrão ytuano.

A turma de diplomados

[que daqui parte, é gloria para o COLLEGIO S. LUIZ, e, ao mesmo tempo,

é honra para a CIDADE DE YTÚ. (PORCHAT)

A reiteração das orações relativas com função de sujeito emula as construções de tópico pendente típicas da oralidade, de forma a criar um cenário imagético, em que a mudança das três cenas apresentadas (a cidade, a igreja e o colégio) se faz pela inserção dos demonstrativos "lá" e "aqui", que restauram e opõem diferentes tempos e espaços. 
A progressão temática do enunciado descritivo-narrativo se faz do mais geral para o mais particular, estreitando o foco no colégio de S. Luiz. Pontua-se a cidade legendária pelas inúmeras torres de igrejas e por ter reabilitado os jesuítas cuja presença se manifesta na edificação da Igreja Nossa Senhora do Patrocínio que, embora recente, se reveste de tradição ao se confundir com a matriz sob cujas abóbadas e em cuja nave antigas gerações de paulistas se ajoelharam, ou seja, se dobraram aos ensinamentos jesuíticos.

O gênero do discurso que entrecruza as modalidades oral e escrita, na medida em que é um texto escrito para ser lido, permite a leitura do elemento "aqui" como conectivo textual e como embreante ${ }^{54}$. $\mathrm{O}$ anafórico "aqui" do texto escrito reconecta a "velha matriz" ao edifício do colégio ao mesmo tempo em que o suporte vocal do discurso permite a leitura de "aqui" como um dêitico. A junção das duas funções ${ }^{55}$ cria programaticamente o efeito de presentificação da longa tradição jesuítica - de caráter matricial:

\begin{tabular}{|c|c|}
\hline \multirow[t]{3}{*}{ ITU } & o casario se espalha pelo aclive da cidade \\
\hline & as campinas se estendem em derredor \\
\hline & $\begin{array}{l}\text { essas torres se levantam } \\
\text { apontam a vastidão } \\
\text { mostram o infinito }\end{array}$ \\
\hline \multicolumn{2}{|l|}{ LÁ } \\
\hline \multirow[t]{3}{*}{ A IGREJA } & santos habitam os seus altares \\
\hline & creaturinhas tenras as mães confiam áquella casa \\
\hline & Varões honraram o nome da terra paulista \\
\hline AQUI & \\
\hline
\end{tabular}

\footnotetext{
54 "A embreagem é "o efeito de retorno à enunciação", produzido pela neutralização das categorias de pessoa e/ou espaço e/ou tempo, pela denegação, assim, da instância do enunciado" (FIORIN: 2005, 179). Embreante é uma palavra cujo sentido é extraído da enunciação: eu, aqui, hoje, etc.

${ }^{55}$ Trata-se da aplicação da dêixis discursiva, por meio da qual "uma formação discursiva não enuncia a partir de um sujeito, de uma conjuntura histórica e de um espaço objetivamente determináveis do exterior, mas por atribuir-se a cena que sua enunciação ao mesmo tempo produz e pressupõe para se legitimar" (MANGUENEAU, 1997:42).
} 


\begin{tabular}{|l|l|}
\hline ESTE EDIFÍCIO & mestres são ministros de Deus \\
\hline & bacharéis saem do ginásio \\
\hline & a turma de diplomados é gloria para o colégio de S. Luiz \\
& é honra para a cidade de ltu \\
\hline
\end{tabular}

Um paralelismo semântico é criado entre o subtópico "igreja" e o subtópico "edifício". Aquela é lugar dos santos e acolhe as crianças; este abriga os mestres que são ministros de Deus e devolve ao mundo criaturas transformadas em bacharéis, glória para o colégio e honra para a cidade.

A exposição das ações jesuíticas e de suas finalidades é realizada pela repetição de estruturas relativas com função de sujeito seguidas do encaixamento de orações adverbiais finais, ritmada como um ofício religioso:

...que melhor sitio do que este recanto adorável,

[onde se congregam esses homens bons e sábios

[que deixaram os lares paternos

[para se consagrarem ao ensino da mocidade

[que se partem das alegrias de suas cidades,

[para levarem ... os fructos da civilisação

[que, abnegados, se internam pelas florestas

[onde vão domar o homem selvagem

[que enleiam vencedores e vencidos no laço de uma pura fraternidade

[prendendo-os, uns aos outros, como

[irmãos nas ideas,

[irmãos no sentimento,

[irmãos na fé;

[que ... desprendem-se dos gosos ephemeros da vida

e se encadeiam nas regras rijas de uma disciplina severa

[para poderem ... cumprir os deveres de servos de Jesus

Nessa admirável Companhia

[que... vai se expandindo, victima das perseguições 
[que explodem em apodos e vilipêndios,

mas de outro lado recebendo os applausos da humanidade,

[que se desatam em bençams e glorificações

Como essas

[que florescem entre os efluvios da gratidão paulista

[que vê desenhar-se... a figura sympahica do padre jesuíta, na personagem excelsa de José de Anchieta, portadora de paz e tranquilidade aos incolas da terra querida. (PORCHAT)

No enfileiramento de estruturas relativas e adverbiais, o lugar se confunde com a finalidade ("que, abnegados, se internam pelas florestas onde vão domar o homem selvagem") e as ações são marcadas pela reflexividade expressa por meio do pronome "se", desencadeada pela revelação. Os jesuítas deixam a casa paterna para "se consagrarem ao ensino". Eles "se partem das alegrias de suas cidades", "se internam pelas florestas", "desprendem-se dos gosos ephemeros da vida", "se encadeiram nas regras rijas". Pela sujeição e submissão, enlaçam-se os irmãos, a Companhia se expande e, como em "uma cadeia dominó", os aplausos se desatam em bênçãos e glorificações. O resultado final é a gratidão dos paulistas que veem nas ações jesuíticas a continuidade da ação primeira, a do padre Anchieta, alçado a pacificador dos índios e, por tabela, a agente da civilização. Nesse sentido, todas as ações jesuíticas são reflexivas da ação da graça divina intermediada por Anchieta ${ }^{56}$.

A sacralização de Anchieta faz parte da estratégia de resgate do "espírito religioso" dissolvido pelo poder temporal e que, por direito divino, deveria ser atribuído à Igreja. A operação de reabilitação ${ }^{57}$ de Anchieta como apóstolo do Novo Mundo que havia sido realizada pelos românticos é reinterpretada na chave de leitura positivista que privilegia o emprego do método científico. Por esse viés, o documento ganha o estatuto

\footnotetext{
${ }^{56}$ Pela palavra de Porchat, os professores do colégio jesuíta refazem o percurso missionário de Loyola e de Anchieta.

${ }^{57}$ No final do século XIX, no bojo da construção de um passado mítico e heroico, a igreja resgatou a figura de Anchieta como elemento de valorização do passado colonial para a reabilitação da imagem da Companhia de Jesus, manchada pelo processo de expulsão pombalina.
} 
de "objetivo, inócuo e primário58" e se transforma no "fundamento do fato histórico", faz do jesuíta anchietano que escrevia poesia na areia a figura mítica e heroica da colonização, por ter colocado os indígenas no desvelo da civilização europeia, ou melhor, do Império cristão. Nesse sentido, o papel de Anchieta e, por extensão da Companhia de Jesus, ia ao encontro do programa civilizatório do Brasil endossado pelos republicanos. Patenteando o caboclo paulista, resultado da mistura do índio e do português apenas, a Companhia assume o mérito da fusão das raças, da unificação do território nacional e da definição da identidade nacional (VILAR, 1999).

O conjunto de relativas restritivas que compreende o primeiro bloco do excerto é uma estratégia retórica que visa a fechar a lente sobre o referente "homens bons e sábios", elevá-lo a um pedestal para dar-lhe tratamento apologético que vem na forma de oração adverbial final. Há o entrelaçamento entre enunciados descritivo-narrativos que referem a congregação dos homens bons e enunciados prescritivos que fornecem uma orientação doutrinária para a leitura do quadro descrito. No segundo bloco, às orações relativas restritivas seguem as relativas explicativas. Essa sequência promove o efeito retórico de estreitar o foco sobre um referente, fornecer-lhe uma interpretação analógica por meio da estrutura apositiva e congelar a imagem para a construção da memória dos eventos ${ }^{59}$.

\subsubsection{A expulsão e o retorno dos jesuítas}

O tema da expulsão e do retorno dos jesuítas é tratado pelo prisma do testemunho dos eventos, denunciado pelo uso do verbo perceptivo do enunciado "Ella viu", contudo sem enquadrar os fatos no tempo e lugar. Além da ausência dos elementos circunstanciais, a imprecisão histórica é programaticamente expressa pelo emprego do particípio absoluto que não traz marcas de número-pessoa e modo-tempo. Por meio dessas estratégias morfossintáticas, o discurso atemporal da circulação das diferentes

\footnotetext{
58 Essa objetividade do documento é uma "ilusão positivista", pois não o isenta de intencionalidade que subjaz a coleta, a escolha e o uso que se faz do documento (PILAR, 1999).

${ }^{59}$ Marilza de Oliveira, comunicação pessoal.
} 
vozes que construíram o imaginário popular sobre a expulsão dos jesuítas se impessoaliza e ganha perenidade traduzida em verdade-histórica, ainda que essas vozes fossem mediadas pelos padres jesuítas.

O emprego da sinédoque para referenciar o paciente das agressões narradas é outra estratégia para eliminar da narrativa os personagens reais e criar um cenário misterioso, em que forças ocultas interditam a (re)legião responsável pela unidade da "Pátria", entendida como "Religião luminosa e fecunda", expressão apositiva que faz aflorar ambiguidade do termo especificado por relacionar fé e política, e sugere que, "na marcha do mundo, é a palavra que o fecunda, não a carne" (ZUMTHOR, 1993:130-131). Afinal, se foi pelo verbo que Deus fez o mundo, foi pela palavração [palavra+ação (gesto corporal e vocal)] que os jesuítas (re)fundaram o tempo, as coisas e os espaços criados por Deus ${ }^{60}$. E é igualmente pelo discurso (palavração) que a intelectualidade "católica" do início do século XX atualiza a ação jesuítica, portadora de um completude, que, segundo esse discurso, só pode ser divina.

$\mathrm{Na}$ sequência figurativa dos referentes, opera-se o apagamento do agente responsável pelo perecimento e emudecimento da Companhia de Jesus, compensado pela exposição do elemento causador ("em nome da liberdade, "em nome do Progresso") e pela estratégia da repetição da estrutura sintática.

O apagamento das marcas morfossintáticas de recuperação dos referentes e o emprego de figuras de linguagem (metonímia e sinédoque) para reconstrui-los são estratégias para recompor e congelar a história pelo viés da doutrina jesuítica. Nas práticas jesuíticas não há espaço para o contingente e o eventual, de modo que os elementos circunstanciais são interpretados substancialmente suegundo uma ordenação prescritiva da história.

\footnotetext{
${ }^{60}$ A Terra de Santa Cruz, uma visão provavelmente edenizada do estado português na América! Sérgio Buarque de Holanda, em "Visão do Paraíso", trata das projeções que o europeu e, sobretudo, os jesuítas faziam sobre o novo mundo.
} 
A observação de que os mesmos acontecimentos históricos recebiam leituras diferentes por parte de ingleses e de havaianos da virada do século XIX levou Sahlins (1990) a refletir sobre a história em termos estruturais. Contrastando as estruturas performativa e prescritiva, descreve esta última como um modelo em que o novo está ausente e na qual "Os acontecimentos são valorizados por sua similaridade com 0 sistema constituído. Aqui, tudo é efetivação e repetição" (p.13). Na estrutura prescritiva da história, o esquema cultural se apropria do evento dando-Ihe uma interpretação histórica. $\mathrm{Na}$ estrutura performativa, verifica-se o movimento contrário. Ambas as estruturas podem ser detectadas em uma mesma sociedade. Os discursos jesuíticos contemplam ambas as estruturas, quando apontam para um "foi, é e sempre será".

O conceito de história aflora da cultura, mas esta também emerge da experiência histórica. $\mathrm{Na}$ "estrutura da conjuntura" determinada pela "realização prática das categorias culturais em um contexto histórico específico", como é o caso da apropriação jesuítica do evento de expulsão e retorno dos padres da Companhia de Jesus, entram em cena leituras simbólicas dos referentes e reificações seletivas.

Ao tratar do retorno jesuítico, o orador apela para a metonímia para embaralhar os referentes e colocar em cena o evento profético da volta do messias anunciado pelo artigo definido "o jesuíta". O cruzamento entre os reiterados segmentos "Ella viu" e a unicidade de "elle voltou" ecoa o atendimento do rogo dos fieis pelo retorno do messias e religa o jesuíta à catequese, ao púlpito, ao confessionário e à cátedra docente. Nesse jogo figurativo referencial, os actantes ganham corpo e o cenário é construído seja pelo complemento circunstancial seja pelas desinências verbais. Paradoxalmente, a emergência dos actantes e dos elementos circunstanciais afasta as noções de contingência e de eventualidade para dar vazão ao cumprimento da profecia. Essa releitura funcional da encenação reverbera as práticas jesuíticas estruturadas prescritivamente, criando uma "historicidade atemporal".

As representações figurativas dos referentes criam o "diálogo simbólico da história" que se estabelece "entre o sentido cultural e a referência prática", como aponta Sahlins (2008). Ao mesmo tempo em que se reordenam culturalmente os eventos, se 
alteram os esquemas culturais por meio da reordenação histórica. Essa operação que se processa em via de mão dupla reproduz uma estrutura ao mesmo tempo em que a transforma. Nesse sentido a repetição é uma estratégia discursiva de renovação católica e de recomposição da história jesuítica.

\subsubsection{A (des)articulação dos espaços físicos e mentais}

O tópico da expulsão e do retorno jesuítas é recuperado pelo resgate de materiais linguísticos de enunciados anteriores, resultando no amálgama sintático. Em um bloco ternário, a repetição da oração reduzida de particípio "acossada" cria o enquadramento sintático-discursivo no qual se exploram os eventos resultantes do banimento dos jesuítas do país por ordem de Pombal, introduzidos pelo verbo perceptivo. Parodiando o terço no plano de organização dos três blocos introduzidos por "acossada" e por "ella viu", o texto vocalizado desfia as contas do rosário e puxa o terço, parodiando as práticas sociais da plateia.

A dramatização rítmica emula a oração do Pai-nosso focando o reino da religião: "A Religião augusta e santa, que fez a grandeza e a unidade de vossa Patria" recupera o início do Pai-nosso "Pai-nosso que estais no Céu, santificado seja o Vosso nome assim na terra como no Céu"...; os "rudes ataques" recuperam "assim como nós perdoamos a quem nos tenha ofendido". Segue a meditação dos mistérios com a repetição e os amálgamas-sintáticos, e finaliza com a emulação do glória na aclamação dos bacharéis, fechando o terço:

A RELIGIÃO augusta e santa, que fez a grandeza e a unidade de vossa Patria, a Religião luminosa e fecunda, [..] soffre os mais rudes ataques, as mais violentas arremettidas.

ACOSSADA NO RECINTO SAGRADO DOS SEUS TEMPLOS -

nessas mesmas cathedraes, onde outr'ora buscavam os fracos e os perseguidos um asylo inviolavel contra a sanha e o furor dos Potentados -

ELLA VIU PROFANADOS OS SEUS ALTARES, enxovalhadas as suas alfaias, 
$\underline{\text { escarnecidas }}$ as suas estatuas

e arrombados os seus proprios tabernaculos

ACOSSADA NOS SEUS MAIS FORTES REDUCTOS

- nesses mesmos mosteiros, onde, em tempos idos, achavam agasalho seguro a Sciencia e a Arte, corridas pelo fogo e pelo camartello dos Barbaros -

ELLA VIU DEVASTADOS OS CONVENTOS, violadas as clausuras, despovoados os eremitérios

ACOSSADA NOS SEUS MAIS INTIMOS RECESSOS

- nesses mesmos ninhos, pendurados dos alcantis, entre a terra e o céo, onde antigamente se afeiçoavam as grandes aguias do pensamento a devassar as profundezas do abysmo e a sondar as alturas do infinito -

ELLA VIU FECHADOS OS SEUS SEMINÁRIOS

trancados os seus collegios,

interdictas as suas escolas

- PARA QUE, Á MINGUA DE BRAÇOS que a cultivassem, PERECESSE A VINHA DO SENHOR; PARA QUE, Á MINGUA DE LABIOS que a murmurassem, EMMUDECESSE, no lar e no presbyterio, A ORAÇÃO PROPICIATORIA.

E toda esta campanha de crueldade e de exterminio se fez em nome da Liberdade, «para proclamar a independencia absoluta do Estado em face de todas as communhões existentes [...] E todas estas iniquidades se consummaram em nome do Progresso, porque a Fé conclamavam os destruidores - asphyxia a sciencia, atrophia o cerebro e desvenera o caracter.

Velhas mentiras, Senhores, a que

a novidade garrida das roupagens reveste apparencias de verdades inconcussas!

Estafado estribilho, que

a tonalidade enfatuada dos barytonos de fancaria avoluma em clangores estridulos de fanfarra marcial!

A vós, Senhores, que sahis laureados de um estabelecimento,

onde os espiritos se formam ao calor da Fé;

onde os caracteres se plasmam á tempera da Religião;

a vós, Srs. Bachareis, incumbe a excelsa e relevante tarefa de serdes, 
pelo vosso preparo e pelo vosso exemplo,

a contestação viva e permanente daquellas imposturas,

o brado altivo e energico, que sobreleve aquella dissonancia. (A. ARANTES)

À repetição do particípio "acossada" se adiciona recursivamente a estrutura do sintagma preposicionado e se introduz um novo referente, permitindo a progressão temática: ACOSSADA [no recinto sagrado dos seus templos $\rightarrow$ nos seus mais fortes reductos $\rightarrow$ nos seus mais íntimos recessos].

As consequências dos ataques resultantes da expulsão dos jesuítas são também marcadas pelo amálgama sintático, em que se repete a primeira parte do enunciado "Ella viu" e a estrutura predicativa do segundo: ELLA VIU [profanados os seus altares $\rightarrow$ devastados os conventos $\rightarrow$ fechados os seus seminários]. A estrutura predicativa, tomada como hiperônimo, é novamente reiterada pelos elementos que o compõem, expondo o esfacelamento de toda a organização hierárquica da instituição: profanados os seus altares [enxovalhadas as suas alfaias $\rightarrow$ escarnecidas as suas estatuas $\rightarrow$ assombados os seus próprios tabernaculos], devastados os conventos [violadas as clausuras $\rightarrow$ despovoados os eremitérios], fechados os seus seminários [trancados os seus collegios, $\rightarrow$ interdictas as suas escolas].

A repetição do segmento "Ella viu" produz a cena do crime do qual os jesuítas participam como vítimas, expropriadas de seus bens, de suas tarefas e de sua organização. Trazer à tona essa "dissonância" é uma forma de manter a memória de um passado de injustiças, atualizado pelo efeito de verdade produzido pela construção "Ella viu".

Na chave de leitura do orador, a expulsão dos jesuítas deve ser debitada à sua atuação vista como um empecilho para as "ideias de Liberdade", de "Progresso" e de "independência absoluta do Estado", uma vez que a fé difundida pelos jesuítas "asphyxia a sicencia", "atrophia o cérebro" e "desvenera o caracter". A repetição da estrutura 
predicativa tem a função de marcar a progressão tópica, em que a degeneração no âmbito da ciência tem efeitos semelhantes no cérebro e no caráter do homem.

A contestação do argumento da degeneração causada pela fé também vem na forma da repetição semântica observada em "velhas mentiras" e "apparencias de verdades inconcussas" e "estafado estribilho" e "estridulos de fanfarra marcial". Já a contestação participativa é atribuída aos bacharéis formados no estabelecimento religioso que devem agir de forma coordenada (tal como a estrutura sintática), contínua e enérgica: "a vós, sns. Bachareis, [...] a contestação viva e permanente [...] o brado altivo e energico....".

\subsubsection{Da derrota à superação}

A expulsão dos jesuítas é capturada pela reprodução de segmentos textuais na forma de construções suboracionais. A listagem de particípios e de adjetivos cria a sucessão de sentenças a que estiveram sujeitos os jesuítas a partir do alvará de 1759. A reiterada marcação da exclamação avoluma a desarticulação dos trabalhos jesuíticos também avolumados pela repetição da intensificação.

As listas de particípios, adjetivos, exclamações e intensificações, por elidirem o suporte, colocam sob os holofotes a ruína da edificação jesuítica e imprimem um ritmo veloz da sentença de expulsão dos jesuítas que não foram submetidos aos trâmites processuais de um julgamento:

E no alvará de 3 de setembro de 1759 bem se especificavam as notas pelas quaes eram declaradas proscriptos os padres da Companhia, exterminados outrosim, desnaturalizados e expulsos de Portugal e seus dominios,

como rebeldes, traidores, aggressores 
e adversos á pessoa e ao governo real.

O povo, esse não tomava partido pelos proscriptos,

e antes prestava aos oppressores todo o concurso da boçal indifferença:

estava bestializado, como da attitude popular em outro succceso opinou conhecido demagogo.

$[\ldots]$

QUE derrota,

QUE descalabro,

QUE desmoronamento geral!

Tudo por terra, de quanto pacientes haviam levantado em mais de dois seculos de indefesso labor!

A obra colosssal da catechese,

TÃO ampla,

TÃO heroica,

TÃO esperançosa, como jámais se planeára em qualquer parte do mundo, - elles a deixavam em meio, e sem condignos successores a quem puderam entregal-a. (LAET)

O orador se apropria da expressão "bestializado", de Aristides Lobo que, em Carta ao Diário Popular de São Paulo, usou a expressão para descrever a deposição do monarca e a recepção do evento militarizado da proclamação da República, interpretado erroneamente como parada militar ${ }^{61}$. O desconhecimento e a surpresa da ordem bem como o ritmo acelerado da sua execução deixam atônito o povo que assiste à debandada dos jesuítas sem nada compreender.

No discurso de Laet, a "desnaturalização" dos jesuítas assume dramatização em proporção maior do que aquela atribuída à deposição do monarca, pois ao serem "desnaturalizados", subtraem-Ihes a identificação, no sentido de que se colocavam como "os

\footnotetext{
${ }^{61}$ Citada por Leôncio Basbaum, em História Sincera da República, de 1889 a 1930 (São Paulo, Fulgor, 1968:18), é recuperada por José Murilo de Carvalho em Os Bestializados. O Rio de Janeiro e a República que não foi. São Paulo: Companhia das Letras, 2013.
} 
naturais da terra", os "estabelecidos" (ELIAS, 2000[1965]). Uma vez desnaturalizados, pelo viés do direito natural, os jesuítas era arrancados de si mesmos.

O retorno dos jesuítas é marcado pela repetição da frase "elle voltou", em que a ordem é quase o próprio Cristo que, injustiçado e incompreendido, um dia voltará. A volta é garantida "com a mansa e irresistível porfia de um mar", figura construída para apontar aquilo que é uma evidência, uma obviedade, segundo a narrativa bíblica. A ideia do retorno é sustentada pela reiteração do verbo "voltou", seguido do complemento locativo que, por trazer informação nova, expressa a conquista de diferentes espaços que edificam o "corpo místico": a catequese, o púlpito, o confessionário e a cátedra.

Ora, O JESUITA, em sua multipla e fecunda actividade, fizera-se o conductor das almas, o grande censor de erros publicos, o mais influente patrono das fraquezas opprimidas. Evidentemente não era possivel supportal-o!

Aniquilaram-no, effectivamente, mas ELLE VOLTOU,

com a mansa e irresistivel porfia de um mar, que na vasante affirma seus direitos á plaga, e em breve a reoccupa.

VOLTOU á catechese,

VOLTOU ao pulpito,

VOLTOU ao confessionario,

VOLTOU á cathedra docente.

Na educação da mocidade em paiz que - ainda mal! - inscreve na sua constituição o indifferentismo religioso, o Jesuita apparece nas primeiras linhas dos educadores, e com os mais fundados titulos reclama o seu posto de honra para affeiçoar a mentalidade brasileira.

Um por um se desfazem os preconceitos e as abusões concernentes ao jesuitismo - nome que só por si levava calafrios á medulla dos papalvos embahidos pela má fé pombalesca.

DA pureza doutrinal,

DA severidade de costumes,

DO acendrado civismo que se professam e aprendem nos collegios da Ordem, dão testemunho eloquente os milhares de alumnos

[QUE nelles estudam,

[QUE nelles se formam e 
[QUE depõem unanimes em prol de seus mestres, varões eximios nas humanas como nas sagradas letras,

[e QUE á razão nenhum dos privilegios retiram que legitimos the conferiu o Creador. (LAET)

A listagem de substantivos abstratos dos sintagmas preposicionados ("da pureza doutrinal", "da severidade de costumes" e "do acendrado civismo") enquadra os parâmetros dos colégios jesuíticos. A justaposição de orações relativas com função de sujeito reconstrói o labor no colégio de cuja pureza doutrinal/severidade de costumes e civismo de que os alunos são testemunhas. Opõe-se a recepção do povo que assiste abestalhada à desarticulação e à expulsão da Ordem, estabelecida pelo alvará de 1759, à recepção dos alunos que são testemunhas da organização e da consistência da atuação jesuítica por estudarem e se formarem na instituição. Enquadram-se dois tempos, distantes historicamente, em um único plano, de certo modo entrelaçando memória e laço social (ZUMTHOR, 1993:139-141).

O orador coloca o auditório no lugar daquele cujos preconceitos já foram desfeitos para teatralizar, pela palavra, o modelo jesuíta de educação em um tempo presente mas que também pode ser omnitemporal (conferido pelo Criador). Por esse viés, o aluno ao qual se dirige pode ser aquele do século XIX como também aquele do século XVI. É como se o testemunho pudesse ser da vista, vivência e da memória, numa tentativa de instauração da "mimesis de uma presença" (ZUMTHOR, 1993) testemunhal.

Os alunos são testemunhas não por serem espectadores, mas por participarem da consolidação da Ordem, por meio da alegoria da renovação da experiência e da tradição jesuítica. Nessa prova testemunhal, os alunos que estudam e se formam no colégio da Companhia Ihe fornecem elementos para uma narrativa histórica. Ao mesmo tempo em que autenticam a narrativa, autorizam a sua consagração dentro da chave de 
leitura que the é própria, "como se o acontecimento histórico fosse a metáfora da realidade mítica62" (SAHLINS, 1990:25). O resultado é a ratificação do discurso jesuítico.

\subsubsection{A solidez, a permanência e a persistência do edifício jesuítico}

Os jogos figurativos dos referentes definem o cenário em um código diferente, em que o "edifício" está para a ação edificante jesuítica, estruturalmente sólida, atemporal e perene. Os seus ocupantes - antigos e novos bacharéis -, que na aparência polarizam a velhice e a mocidade, adquirem conotações novas opondo a tradição, o perene ao perecível, o conteúdo ao contingente. Pelo prisma da releitura funcional das duas categorias sociais, a "solução de continuidade", ou seja, a união entre o que é perene e o que é perecível é inexequível e deve ser evitada em favor da projeção do corpo místico que sobreleva os corpos degeneráveis. As práticas associadas às categorias sociais alimentam a ideia de continuidade entre o "ginásio" e o "colégio" jesuíticos, entre o presente e os primórdios, entre as pessoas históricas e as categorias abstratas, acentuando os valores sólido e perene da cultura jesuítica.

O encontro entre os antigos e os novos formandos se dá na imutabilidade da ideologia do colégio jesuítico que se reproduz no ginásio em um cenário destemporalizado e desterritorializado. Nesse sentido, o "edifício" jesuítico é sempre o mesmo: duradouro, hospitaleiro, iluminado, acolhe e encaminha os discípulos, reproduz e amplifica as vozes da maestria. Unificados no corpo místico pelas tradições escolares, os mestres se confundem com o sistema constituído e sedimentam uma historicidade de permanência, de perenidade.

Nos dois exemplos abaixo, a repetição de construções oracionais é entremeada de longas digressões, as quais dificultam o acompanhamento da progressão temática, particularmente no caso do discurso que se faz pela modalidade oral. A repetição da construção oracional tem, portanto, a função de reiterar a ideia contida no supertópico.

\footnotetext{
${ }^{62}$ A máxima é usada por Sahlins para explicar a objetivação do Deus do Ano Lono feita pelos sacerdotes havaianos, por meio da chegada dos ingleses no período da fertilização da terra.
} 
O mecanismo da repetição, ao recuperar o supertópico insistentemente, congela-o e o consolida na memória do ouvinte:

... abandonais hoje o remansado phalansterio de vossa meninice e ides entrar, em campo aberto, para o fragor das batalhas e para a effervescencia das pelejas.

LÁ [...] encontrareis cooperadores valentes, companheiros esforçados e destemidos.

[...] Ide, ide despressa em seu auxilio, que são vossos irmãos! Foram, como vós, alumnos deste collegio. Educou-os a mesma fé; alenta-os a mesma esperança; querem vencer comvosco a mesma campanha.

Desfigurou-os a edade? [...]Prostra-os o cansaço? Não os extranheis por isso; offerecei-Ihes, ao envés, o conforto de vosso braço, o contingente de vossa mocidade e de vossa bravura.

Não, não queiraes estabelecer soluções de continuidade entre o presente, que vos nobilita, e o passado, que de vós não desmerece.

O GYMNASIO DE HOJE É O PROLONGAMENTO DO COLLEGIO DE HONTEM.

Vêde:

O EDIFICIO É SEMPRE O MESMO, amplo e magestoso, resistindo sobranceiramente ao perpassar destruidos dos annos e das edades á semelhança desses monolithos enormes, solitarios, que - erguidos na vastidão intermina dos mares - zombam dos vendavaes e das tormentas e oppõem a dureza adamantina de suas arestas inquebraveis ao embate impetuoso das ondas espumantes de cólera e frementes de revolta.

O EDIFICIO É SEMPRE O MESMO, alegre e franco,

distendendo para nós, n'um amplexo carinhoso, as suas duas alas hospitaleiras, como si fossem aquellas brancas azas desdobradas de uma pomba, a cuja sombra quizera abrigar-se o Psalmista: sub umbra alarum tuarum sperabe.

O EDIFICIO É SEMPRE O MESMO, com os seus longos corredores, que a piedade de gerações successivas povoou de retratos e de paineis; com as suas salas vastas e arejadas, onde penetra, a flux, a claridade triumphal do sol, pedindo meças á aurora esplendorosa, que aos vossos cerebros se entreabre.

O EDIFICIO É SEMPRE O MESMO: LÁ está a velha capella, silenciosa e triste, mostrando, na tocante simplicidade do seu altar, a imagem veneranda da Virgem do Bom Conselho, - dádiva mysteriosa do Céo a quem 
recebera o encargo providencial de ser o Propheta e o Precursor desta benemerita fundação.

LÁ está, no tópo da escada, a formosa allegoria, que a devoção do religioso inspirou ao pincel do artista, e na qual a figura dominante do Anjo Custodio, senhoril no porte e resoluto no aspecto, amparando com uma das mãos a fragilidade timida de uma criança e apontando-Ihe com a outra a róta difficil da patria longinqua, bem poderia representar, na mais expressiva das concepções, a obra meritoria deste Collegio de S. Luiz a encaminhar os seus discipulos de todos os tempos pelas veredas ingremes e esmarridas, que conduzem, sem transvios e sem emboscadas, ao pincaro da montanha sagrada, onde reina a Paz e viceja a Virtude.

Sim, O EDIFICIO É SEMPRE O MESMO: attesta-o o proprio salão, scintillante de luzes, em que nos achamos reunidos. Attesta-o este palco, de onde vos chega a minha voz, como si fôra o echo evanescente e quasi extincto de uma outra voz, partida deste mesmo peito, e que, neste mesmo logar vibrou outr'ora tantas vezes, ungida de innocencia e repassada de ternura, traduzindo as fortes e puras emoções, que só a virgindade das almas infantis sabe experimentar e communicar, através da limpidez crystallina de sua dicção, através da ingenuidade encantadora de seu gesto.

$[\ldots]$

Procedemos todos do mesmo passado; é commum o patrimonio de nossas mais queridas tradições escolares.

Pois bem; que essa identidade de sentimentos, que essa conformidade de affectos e de impressões sejam o estimulo e os élos de perenne alliança fraternal entre nós.

Fædere et religione tenemur ${ }^{63}$ - tal deve ser o nosso mote. (ALTINO ARANTES)

Inúmeros são os caminhos que sintonizam o discurso ao conteúdo dos textos sagrados. Entre eles, salientamos a remissão ao salmo 17.8 cujo conteúdo se expressa em língua latina sub umbra alarum tuarum sperabe: "Guarda-me como a menina dos olhos, esconde-me à sombra das tuas asas, dos perversos que me oprimem, inimigos que me assediam de morte". Assim como o versículo parece tratar de um lugar virtual -

63 “Estamos vinculados por tratado e Religião", lema da Casa Real de Saboia, adotado pelo Rei Vittorio Amedeo (1666-1732). 
asas de Deus -, materializado pela palavra do Salmista, o Colégio, embora fundado sobre a materialidade do mundo, é também virtualidades, se levarmos em conta o conceito etimológico de "virtual". Recuperado do latim medieval virtualis, deriva do latim clássico virtus/utis, com o valor de "força corporal, ânimo, ferocidade, força de espírito, virtude, amor e prática do bem, poder de eloquência, castidade".

O Colégio, lugar maravilhoso de feitos extraordinários, é, antes de tudo, o lugar de formação. Em vez de ser um lugar no qual se permanece, o Colégio permanece naquele que por ele passa. Afinal, o lugar do jesuíta é o lugar da ação "no mundo e do mundo, não enclausurado e distante, mas em confronto com o pecado e a agitação" (WRIGHT: 2006:22). Assim como os jesuítas, os meninos saem da meninice, talhados para as batalhas em campo aberto, no mundo, onde encontrarão os "cooperadores valentes, companheiros esforçados e destemidos", pelejando a peleja jesuítica e que um dia também foi a peleja de Cristo: "Abandonais hoje o remansado phalansterio de vossa meninice e ides entrar, em campo aberto, para o fragor das batalhas e para a effervescencia das pelejas". Nesse sentido, o Colégio é o lugar da preparação do espírito para as batalhas que acontecem lá fora: "Ide, ide depressa em seu auxilio, que são vossos irmãos! Foram, como vós, alumnos deste collegio. Educou-os a mesma fé; alenta-os a mesma esperança; querem vencer comvosco a mesma campanha". Essa campanha parodia a que Cristo legou aos seus apóstolos: "Ide por todo o mundo, pregai o evangelho a toda criatura" (Marcos, 16:15).

A repetição do enunciado "o edifício é sempre o mesmo", como prolongamento daquilo que é a pedra fundamental, referencia o "edifício de Deus" onde se desdobra a função litúrgica e de pregação cujo único alicerce é Jesus Cristo (1 Co 3.11 - NVT), e tem a função de reiterar a ideia contida no supertópico "O gymnasio de hoje é o prolongamento do collegio de hontem". Além do congelamento do tópico na memória, a recursividade do enunciado realiza a função de marcar a solidez da instituição e instaurar a tradição escolástica, em que a fé e a religião devem ser procuradas visando à união dos indivíduos, atualizando o programa exposto no século XVII pelo jesuíta Antônio 
Vieira cuja obra estava voltada para a "redenção coletiva como um 'corpo místico' unificado (HANSEN, 1999:25).

A construção da ideia de permanência e solidez é também retomada pelo orador de formação não-bacharelesca. Laet, formado pela Escola Politécnica do Rio de Janeiro, emprega o advérbio na qualificação dos jesuítas ("humilde sempre"; "sempre (dis)posto") para codificar a ideia de totalidade, continuidade e valor confirmativo, e o locativo "onde" esvaziado de especificação com escopo os perseguidores da ordem jesuítica:

ONDE estão, eu vos pergunto, os perseguidores da Ordem?

$[\ldots]$

ONDE está Pombal,

ONDE os seus asseclas, que aleives?

Mas o Jesuita, vós ahi o vêdes, senhores, humilde SEMPRE,

SEMPRE disposto ao serviço, «sicut qui ministrat» (Luc. XXII, 27):

SEMPRE disposto ao bem, ao esquecimento dos aggravos, á continuação dos beneficios. (LAET)

No excerto abaixo, o quantificador universal "tudo" nucleia o sujeito sintático do predicado verbal que assinala insegurança e incertezas; o intensificador "muito", por sua vez, modifica o verbo que traduz as ações dos jesuítas:

TUDO está em questão,

TUDO vacilla em terreno vulcanico,

e tristemente interrogativo se desenha o dia de amanhã.

No meio destas angustias, benemeritos membros da Ordem que por excellencia se proclama obediente,

MUITO podeis fazer,

MUITO já tendes feito,

MUITO espero que ainda façaes, preparando estes moços, que hão de ser os homens de amanhã. (LAET) 
A obediência que aparece no proclama da Ordem vem marcada iconicamente ${ }^{64}$ pela função do adjunto adverbial frequentativo "sempre disposto" e do intensificador "muito" que modifica o aspecto e o modo verbal. Em contraposição ao esvaziamento do locativo "onde" e do quantificador universal "tudo", que operam nuclearmente na sentença, os modificadores expressam o contorno dos fatos expressos por outras categorias subsidiando-as. Apesar de e justamente por suplementarem diferentes categorias, os modificadores desempenham a função de ratificar e universalizar a ideologia jesuítica de sujeição, dando-lhe uma dimensão histórica. A lógica atual que atribui o valor universal ao quantificador "tudo" sobrelevando-o ao advérbio aspectual frequentativo "sempre" não recupera a força totalizante, contínua e confirmativa usada no discurso, em que a lógica cultural jesuítica atualiza a subordinação manifesta na estrutura social e na estrutura gramatical ${ }^{65}$.

No excerto do discurso de Leal, abaixo transcrito, a repetição do enunciado "Elles aqui ficam" veicula a ideia da onipresença e onisciência dos mestres, que sabem da preparação dos alunos para o enfrentamento das agruras que encontrarão fora dos muros da escola:

Mas, si os paes, a par do consolo da ausencia pela certeza de vos haverem bem confiado a estes educadores, teem o balsamo periodico do vosso regresso, no fim de cada anno lectivo, não o teem, agora, OS VOSSOS MESTRES, ao desertardes desta casa...

ELLES AQUI FICAM saudosos, sem o consolo de uma volta em férias

e sem a tranquillidade de vos entregarem a quem véle por vós, como elles o fizeram, tranquillisando a vossos paes; mas, antes,

ELLES AQUI FICAM, fundadamente temerosos

de que seus exforços em prol da verdadeira sciencia e da virtude de vossas acções sejam inteiramente nullificadas pela acção corrosiva do meio em que ides viver, com todos os

\footnotetext{
${ }^{64} \mathrm{O}$ princípio da iconicidade postula a relação de similaridade entre forma linguística e princípios extralinguísticos.

${ }^{65}$ Ao estudar os havaianos, Sahlins (1990) trata da presença das categorias de pensamento na estrutura social e na estrutura gramatical. Não assume, porém, a ideia de que categorias gramaticais determinam categorias de pensamento. A "homologia das estruturas do pensamento com as estruturas sociais" também é recuperada por Certeau (2011).
} 
seos attractivos fascinadores, que facilmente pervertem, por irem ao encontro das tendencias más da fragilidade humana.

ELLES AQUI FICAM, vendo-vos partir,

não mais chorosos, como, quando, pela vez primeira, deixastes o tecto paterno, mas, radiantes de alegria pelos louros que colhestes, pelo ruído desta festa, e pelos abraços de vossos paes.

ELLES AQUI FICAM, esperando o olvido da maior parte,

a calumnia e a ingratidão de muitos, e

a perseguição de alguns de seus discipulos, - aqui postados como um pharol, a illuminar as ondas indifferentes, que vão e vem, das gerações, que se succedem, tendo por única recompensa a serenidade tranquilla de sua consciencia, na austeridade de sua vida, e a fundada esperança do gozo eterno. (LEAL)

O excerto acima parodia a subida de Moisés e dos sacerdotes purificados ao monte Sinai para encontrar Deus e a permanência do povo ao pé do monte sob a advertência de que não se deve ultrapassar os limites para vê-lo (Livro Êxodo, 19.3, 19.17 e 19.21 VT). Entretanto, no jogo da conservação e da subversão de estruturas (BOURDIEU, 1983), o embreante "aqui" do enunciado "Elles aqui ficam" inibe a leitura do afastamento do povo e remete à participação figurativa dos mestres no monte-colégio, os quais estão legitimados a ocupar uma posição simbólica de autoridade. Os mestres ficam como um farol a iluminar a palavra de Deus.

A palavra de Deus é o que permanece, talvez, na figura dos Mestres, sob o risco sempre iminente do olvido: "A tua palavra é a verdade, desde o princípio, e cada um dos teus juízos dura para sempre" (Salmo, 119:160); "Mas a palavra do Senhor permanece para sempre" (Pedro, 1:25). Essa emulação sacraliza os mestres, os quais, como colunas da instituição, são autorizados a ficar e a se apresentar como faróis das gerações seguintes.

\subsubsection{A idealização do jesuíta como libertador}

Ao longo do século XIX, a imagem da Companhia de Jesus sofreu arranhões desencadeados com a sua restauração em 1849, a partir da qual engrossaram as 
manifestações antijesuíticas que culminaram na "Questão religiosa" na década de 1870 - desavenças entre a Maçonaria e o Bispo de Olinda, D. Vital. Essas manifestações imputavam aos jesuítas o estigma de atraso cultural reelaborado pelas narrativas românticas por meio da analogia entre o hábito negro e a religião criada por Stendhal ${ }^{66}$ e provavelmente apropriada por Varnhagen para explicar a mancha da escravidão.

Para desconstruir o estereótipo e edificar a Companhia, os oradores apelam para a atualização da visão do papel dos jesuítas na libertação dos indígenas à selvageria e ao escravismo dos colonos. Salientavam a ideia de que os jesuítas cooperavam com o poder civil ao direcionarem os indígenas no caminho da civilização, por meio da recuperação da "memória da experiência" e da "previsão do futuro67", alertando os jovens do perigo existente fora dos círculos jesuíticos.

Essa abordagem se insere na lógica jesuítica. A dupla reprodução da tradição cultural jesuítica em que se mesclam a conservação do passado e a prevenção aos eventos futuros já se encontra na escrita quinhentista a qual concentra "uma repetição ortodoxa, que preserva o passado da traditio das autoridades canônicas, e uma repetição missionária, que avança baseada na tradition aplicada aos dados simbólicos preservados e adaptados às novas situações..." (HANSEN, 1998:363).

No espaço dedicado ao encômio de suas ações, o modelo de produção simbólica da tradição cultural dos jesuítas torna-se o paradigma das ações históricas dos oradores, que, na linha do habitus de Bourdieu (1992), por partilharem o mesmo universo, estão sujeitos às mesmas operações conceituais.

\footnotetext{
${ }^{66} \mathrm{Em} 1830$ Stendhal publica "O vermelho e o negro", em que uma das leituras possíveis seria a de que o negro metaforizava a carreira eclesiástica e o vermelho as armas, a carreira militar. A metáfora pode ter sido usada para criticar os jesuítas e responsabilizá-los pela parte sombria e triste da França, por serem, na visão de Stendhal, representantes da igreja retrógrada e associados ao Antigo Regime Francês. (Agradeço a Érica Bertolon pelos comentários.)

${ }^{67}$ A "previsão do futuro" parece ser uma tópica jesuítica. Lembramos aqui a previsão do Quinto Império Português, realizada por Antonio Vieira.
} 


\subsubsection{O jesuíta como abolicionista}

A versão do jesuíta como difusor da civilização e, nesse sentido, como "coadjuvador do poder civil", é depreendida dos espaços de atuação da Ordem. O arsenal linguístico para a marcação desses espaços é a reiteração do sintagma preposicionado encabeçado pela preposição "em" que, recuperando a noção primeira de movimento para dentro, produz iconicamente a apreensão de uma intervenção invasiva. Afinal, os jesuítas "se internam pelas florestas onde vão domar o homem selvagem" (PORCHAT):

Quem haverá, sufficientemente versado na historia patria, e que não deplore essas brutalidades e ingratidões, com que o sectarismo despremiou os mais sinceros e efficazes coadjuvadores do poder civil,

no desbravamento das selvas,

na fundação de povoados,

na extincção do canibalismo,

na conversão do caboclo,

na sua adaptação ás necessidades sociaes,

na diffusão do christianismo,

- aqui, como em todo o mundo, valoroso prégoeiro da vida em commum, e do melhoramento da sociedade terrena, sem perder de vista os finaes destinos do homem? (LAET)

Na leitura dos oradores, o exercício da civilização encontrava como obstáculo a ambição dos escravizadores (colonos e bandeirantes) a qual perpetuava a desigualdade social:

Esse odio do escravismo contra os libertadores, tão claramente assignalado em épocas não remotas da nossa historia, explica os rancores

do colono contra o Jesuita, do bandeirante adverso ao padre, do escravizador de selvagens contra o catechista

[que, chamando-os ao trabalho, ao mesmo tempo Ihes ensinava 
[que eram nossos irmãos.

Eis uma das razões de queixa contra o Jesuita. (LAET)

A sociedade profundamente desigual e hierarquizada, e regida por uma mentalidade predatória, repelia as operações jesuíticas de tal forma a criar os polos colono $X$ jesuíta, bandeirante $X$ padre, escravizador $X$ catequista, marcados pela repetição da estrutura de $X$ contra.

A figura jesuítica construída pela série apositiva (condutor das almas, censor dos erros públicos e patrono dos oprimidos) extrapolava a esfera religiosa e incomodava a sociedade:

Ora, o Jesuita, em sua múltipla e fecunda actividade, fizera-se

o conductor das almas,

o grande censor de erros públicos,

o mais influente patrono das fraquezas opprimidas.

Evidentemente não era possível supportal-o! (LAET)

O incômodo estava todo concentrado no tratamento dado ao indígena, cuja independência fora decretada pelo Diretório pombalino. Apesar de os jesuítas terem voltado antes da abolição da escravatura, nenhuma menção é feita aos negros. Aproveita-se, entretanto, de todo o discurso que envolve a recente abolição para dar aos jesuítas a patente de abolicionista - dos índios. Nesse sentido, dá-se continuidade ao programa dos românticos que colocavam o índio sob a mira das lentes literárias, artísticas e históricas. 


\subsubsection{0 jesuíta como preparador: a prevenção dos perigos}

O alerta aos perigos se faz pela oposição entre as abóbadas do colégio jesuítico e outras abóbadas, marcada pelo locativo "onde", com o qual se contrapõe a condução do mestre e o guiar dos santos à ausência de santos e imagens, à falta de fiscalização e proteção, ambiente propício para se deixar arrebatar pelas "seducções da liberdade". A troca dos mestres pelos novos companheiros de estudo e pela "orgia das ideas" contidas nos livros "seductores" de Schopenhauer, Hartmann e Nietzsche põe em ruína a moral, a religião e a ciência, bases que sustentam a Ordem jesuítica. Tais ideias são colocadas pela repetição do locativo "onde", de estruturas oracionais e do marcador temporal "depois" que enquadra a ruína das bases jesuíticas:

\begin{tabular}{|l|l|l|}
\hline ONDE faltam santos e imagens & faltam tradições & $\rightarrow$ Liberdade \\
\hline $\begin{array}{l}\text { ONDE faltam fiscalização e } \\
\text { proteção }\end{array}$ & faltam ensinamentos puros & $\rightarrow$ Orgia das ideias \\
\hline ENTÃO pessimismo & DEPOIS desespero & $\begin{array}{l}\rightarrow \text { DEPOIS } \\
\text { alucinações }\end{array}$ \\
\hline (FIM) da moral & da religião & $\rightarrow$ da ciência \\
\hline
\end{tabular}

De sob ESTAS ABOBADAS,

[onde viestes sempre conduzidos pela mão do mestre,

[e guiados pelo olhar, sereno e meigo, desses sanctos,

[que adornam as paredes dessa casa [...]

- ides para debaixo de OUTRAS ABOBADAS,

[onde não vereis os perfis eloquentes dos sanctos e das imagens,

[onde tereis de marchar livres desta fiscalisação continua e protectora,

[e onde o vosso espirito, fascinado pelas seducções da liberdade, vai expandir-se contente sobre as maravilhosas conquistas da sciencia.

Mas ahi, meus caros amigos, ao lado das magníficas opulências, é que os abysmos atrahentes se enfloram, pompeando irresistíveis, para arrebatar as almas dos jovens na voragem terrível de suas profundezas. 


\section{[...]}

Não faltarão companheiros de estudo, nem livros seductores, que vos incitem

[a fugir das tradições da escola em que criastes,

[a deixar os ensinamentos puros recebidos no sanctuario da família,

[e entrar nesse mundo onde reina a orgia das idéas, e onde se entra com a cerimônia vaidosa da incineração de todas as crenças puras. [...]

E ao envez daquella philosophia que Ihes alentava a vida, conduzindo os seus pensamentos para a comprehensão da superioridade do destino do homem, entra-Ihes pelo cérebro um oceano de idéas negras, que o fazem sossobrar num doloroso scepticismo.

EIS, ENTÃO, dominando-os, o pessimismo frio de Shopenhauer [ .... .

DEPOIS, é o desespero assustador de Hartmann [...].

DEPOIS, são as allucinações extravagantes de Frederico Nietzsche, que

$$
\begin{aligned}
& \text { combatendo a moral, } \\
& \text { combatendo a religião, } \\
& \text { combatendo a sciencia, }
\end{aligned}
$$

[pretende crear uma humanidade livre, entregue exclusivamente à sua natureza [...]

Essas theorias, [que satisfazem a vaidade balofa de certos pensadores,

[empolgam traiçoeiramente o espírito dos moços,

[e ahi exercem a sua acção funesta como o mais mortífero dos venenos.

É contra esse perigo, jovens bacharéis, que é meu dever premunir-vos. (PORCHAT)

A ideia de que a sabedoria provoca desarranjos é recuperada da Bíblia (1 Coríntios, 1.18 a 31) em que se afirma que "Deus tem mostrado que a sabedoria deste mundo é loucura". É a partir desse viés que se lê o pessimismo de Shopenhauer, o desespero de Hartmann e as alucinações de Nietzsche, incapazes de conhecer as verdades espirituais porque não são espirituais, não receberam a Graça divina. Por sua vez, a Ordem que fomenta a veneração dos santos, opera a fiscalização contínua e protetora, integra um "corpo místico unificado na vontade de integração de seus membros" (HANSEN, 1995:111), se aliena do poder e se subordina livremente à pessoa sagrada que representa a soberania popular, visando ao "bem comum". 
Frente aos perigos elencados fora dos círculos jesuíticos, os bacharéis formados pelo colégio da Companhia são felizardos por terem recebido a mensagem profética, tendo sido orientados e educados na cartilha do Catolicismo, por meio da qual se aprende a ciência imantada pela fé e pela religião, e se forma o caráter blindado dentro dos moldes da moral que perfila os santos e os heróis:

FELIZES DE VÓS, SRS. BACHAREIS, QUE

- rectamente orientados na comprehensão da vida

e no evoluir dos acontecimentos -

[não conhecereis jamais as oscillações da fraqueza,

[que pede um arrimo, e nem as agonias da duvida,

[que reclama um norte.

FELIZES DE VÓS, SRS. BACHAREIS, QUE

- educados nas licções indefectíveis do Catholicismo -

[aprendestes a sciencia ao clarão da Fé;

[desenvolvestes o vosso entendimento ao cálido conchego da Religião,

[e informastes o vosso caracter nos moldes severos e puríssimos daquella Moral eterna e immutavel,

[que canoniza os santos, sagra os heroes e gera os superhomens.

FELIZES DE VÓS, SRS. BACHAREIS, QUE

ao deixardes este Collegio,

[levareis comvosco um patrimônio de convicções e de princípios, [que vos permittirá arrostardes, imperterritos e incólumes, as agruras e as provações do longo e escabroso jornadear.

(A. ARANTES)

O bloco de relativas acima apresenta ambiguidade estrutural e interpretativa, quase a desenvolver "técnicas acrobáticas da sintaxe" (ZUMTHOR, 1993:187), 
dependendo da escolha do núcleo do antecedente do pronome relativo, "bachareis" ou "vós".

A relativa restritiva reduzida ou fundida na oração adverbial causal/temporal toma por antecedente "bacharéis" sobre os quais se predica:

$\begin{array}{lll}\text { Bacharéis } & \text { [que se orientam retamente ] } & \text { não conhecerão oscilações } \\ \text { Bacharéis } & \text { [que se educaram no catolicismo ] } & \text { aprenderam a ciência pela fé } \\ \text { Bacharéis } & \text { [que deixam este Colégio ] } & \text { levam um patrimônio de convicções } \\ & \text { = restritiva//causal/temporal } & \text { = principal }\end{array}$

Essa distribuição sintática leva a duas interpretações a respeito dos bacharéis do Colégio jesuítico: 1 . Só os que se orientam retamente não conhecerão oscilações; 2 . Por que se orientam retamente não conhecerão oscilações. A primeira dá conta da constatação por ocasião da formatura e a segunda procura persuadir os que estão fora do colégio a integrarem a instituição jesuítica.

A relativa restritiva desenvolvida toma por antecedente o pronome "vós" (aqueles que não conhecem oscilações) ao mesmo tempo em que pode ser interpretada como uma coordenada explicativa por meio da qual se procura dar razões para o estado de felicidade (Sois felizes pois não conhecereis oscilações):

Felizes de vós [que não conhecereis oscilações

Felizes de vós [que aprendestes a ciência pela fé

Felizes de vós [que levareis um patrimônio de convicções

$=$ restritiva/coordenada explicativa

Uma leitura performativa do enunciado "Felizes de vós, bachareis", no contexto situacional de formatura em que foi proferido o discurso, autoriza a leitura do ato de parabenizar o bacharel por ter se preparado para não conhecer oscilações. Orientados 
e educados no colégio jesuítico, os alunos não serão presas de abatimento moral porque levam consigo um cabedal de convicções e de princípios da Religião que, emulando o convite para a ceia do Senhor, os conecta com a luz difusa da Graça. Com efeito, a repetição do enunciado "Felizes de vós, srs. Bacharéis" parodia a tradição litúrgica da Celebração da Palavra de Deus: "Eis o mistério da fé. Felizes os convidados à ceia do Senhor. Quem come da minha Carne e bebe do meu Sangue permanece em mim e eu nele. Eis o Cordeiro de Deus que tira o pecado do mundo". A emulação da tradição litúrgica da Celebração da Palavra de Deus reforça no imaginário dos bacharéis o pacto de sujeição e o compromisso com a palavra de Deus.

\subsection{DOS PANEGÍRICOS}

A tópica do panegírico tem como cerne o elogio a uma figura. Visando a construir um quadro ideal, a exaltação revela o compromisso com a verdade revelada das escrituras. Além disso, por ser uma obra escrita com destinação vocal, o plano linguístico se combina com vários planos de realização, de que resultam várias figuras caleidoscópicas que ganham eficácia na performance do orador:

É na performance que se fixa, pelo tempo de uma audição, o ponto de integração de todos os elementos que constituem a "obra"; que se cria e recria sua única unidade vivida: a unidade desta presença, manifesta pelo som desta voz. (ZUMTHOR, 1993:163)

Proferidos nos dias festivos da visita do primeiro cardeal brasileiro, D. Joaquim Arcoverde, os panegíricos datam de 30 de junho e 01 de julho de 1906. Pregados por um Monsenhor, um padre jesuíta e um arcipreste, os panegíricos têm como figura central S. Luiz Gonzaga, nome atribuído ao colégio jesuítico em Itu. Aparentemente, a figura de 
S. Luiz é retratada para acentuar as características do santo e, com isso, apontar um exemplo de virtude para os moços que se bacharelavam no colégio.

O exórdio dos panegíricos é aberto com uma fórmula latina, nem sempre seguida de tradução, que explicita uma autoridade, pois que é seguida de referência bíblica. A citação de autoridade "remete a um texto social, virtual mas incontestável, palavra tradicional e pública, construindo um plano de referência..." (ZUMTHOR, 1993:196), e condensa o teor do discurso. O Arcipreste Fontoura abre e fecha o discurso com a mesma citação latina, sem o aporte da tradução em língua portuguesa: Congregamini et vincemini, quia nobiscum Deus (Isaias, cap.8 - v.9); o texto do Padre Fialho traz em sua abertura uma citação latina que não se repete no fechamento da conclusão do discurso e não traz o aporte da tradução: Inspice, et fac secundum exemplar, quod tibi monstratum est.... (Ex. XXV, 40); o texto do Monsenhor Costa é precedido da citação latina seguida de tradução, Hostiam viventem, sanctam Deo placentem ("Hostia viva, santa e agradável a Deus"; S.P. ad Rom XII-1), que se repete várias vezes ao longo do texto, o qual é encerrado com uma expressão latina como um "ultimo suspiro": Te Deum ladamus, te Dominum confitemur.

As citações latinas se sacralizam, por oposição ao discurso em português, e funcionam como um ato ilocucionário (AUSTIN: 1990) que de um lado explicita e realiza a performatividade da sentença dada por "uma voz externa, fora do tempo, sem espaço, presença pura" (ZUMTHOR, 1993:196) e, de outro lado, evocando a fórmula sacramental do batismo retomado na conversão, explicita o comportamento atitudinal de aceitação e sujeição à sentença exemplar do santo, figura ideal construída dentro dos preceitos jesuíticos.

Para além do enquadramento das citações latinas, os panegíricos são compostos de forma a marcar a ostensividade por meio de formas de saudação e de invocações. Monsenhor Costa saúda sequencialmente o cardeal e os jesuítas ("Eminencia, Meus amados Irmãos") no exórdio do discurso. Invoca o cardeal para sublinhar sua permanência no colégio de Itu e, com isso, ressaltar o vínculo direto do colégio com o pontífice; em seguida, faz o chamamento dos jesuítas para dar início ao discurso. $O$ 
Arcipreste Fontoura menciona a presença do cardeal, mas o saúda indiretamente, mencionando o título "Roma Brasileira", para retomar o "lugar que representava a plenitude papal" (WRIGHT, 2006:23), vinculando-a à "legendária cidade de Ytú" que recebera a visita do monarca e que agora recebia a visita do primeiro cardeal brasileiro. Relata ter sido convidado pelo reitor para elaborar o panegírico e invoca os alunos ("permitti-me agora ó jovens alumnos..."; "Juventude estudiosa, vós estaes no primeiro período da vida, a aurora."). O Padre Fialho invoca a plateia de forma generalizada "senhores", no texto que rotula como "sermão". Apesar de cada autor nomear o seu texto de uma maneira (discurso, panegírico e sermão), todos eles aparecem renomeados como panegíricos na capa da brochura que os contem.

De forma geral, o quadro formular explorado pelos panegíricos permite a identificação de pelo menos três tópicas que são exploradas pela estratégia de repetição na construção textual: 0 atrito entre pai e filho, a mocidade e a educação.

\subsection{1 $O$ atrito entre pai e filho}

O atrito ente pai e filho é explorado pela repetição de um único item lexical - "seu pae" -, continuamente dispersa pela digressão em torno das vicissitudes de Luiz de Gonzaga mas retomada em posição de sujeito sintático, com função agentiva dos encaminhamentos tomados pelo filho Luiz que, no papel temático de paciente em posição de complemento verbal, se subjuga às ordens paternas.

Entretanto, "sempre respeitoso e firme como um rochedo" o filho inverteu as regras do jogo. Assumindo a posição de sujeito sintático e a função semântica de agente, em atitude resiliente, Luiz "desarmou seu pae", "conseguiu nova permissão", "partiu para Roma", "foi beijar os pés do papa". Essa sequência de ações aponta a submissão voluntária de Luiz aos desígnios papais, "implorando sua bençam paternal".

Luiz não "desarmou o pae" por ser um jovem libertino, mas para se sujeitar a um pai maior - o papa - , o qual dava "bençam paternal" e não "paterna". O adjetivo "paternal" cria paralelismo com a disposição maternal de ter gerado Luiz de Gonzaga e 
de o ter direcionado à Companhia: "auxiliado pelo zelo maternal, que não fez senão desenvolver em sua alma - a graça do santo Baptismo, - na idade de sete annos o menino resolve, propõe-se e decide-se á não viver senão para servir a Deus". Além disso, no momento em que revelou sua resolução de entrar na Companhia, "Sua extremosa mãe inundou-se de uma santa alegria com esta revelação". Diferente foi o pai que tudo fez para desviar o filho de sua vocação e que se revelou instável ao autorizar e desautorizar o filho na sua escolha religiosa:

SEU PAE, Fernando de Gonzaga, Marquez de Castilhão, docemente impressionado com a vivacidade de seu angelico filho, pensou ter elle vocação para as armas. [...]

SEU DESVELADO PAE o leva a Florença para encetar seus estudos com seu irmão Rodolfo. É, principalmente, nessa circumstancia, que Luiz se tornou o modelo completo da mocidade. Luiz obedecia a seus professores, estimava seus collegas, e sujeitava-se jubilosamente aos sacrificios inherente á vida collegial.

SEU PAE, triando-o do Collegio ao terminar seus estudos preparatorios, o levou para a côrte do rei Guilherme. Filho obediente, ahi permaneceu o tempo preciso [...]

A Companhia de Jesus esta em todo o vigôr de sua prodigiosa fecundidade. Luiz de Gonzaga ainda na côrte do rei Guilherme, lia constantemente as cartas desses jovens missionarios relatando a seus superiores os trabalhos e os resultados de seu penoso apostolado.

Sua nobre resolução de entregar-se exclusivamente ao serviço de Deus transforma-se na resolução de entrar na Companhia de Jesus. [...]

SEU PAE, entretanto, ainda o expõe a novos perigos, levando-o á côrte da Hespanha, amiga dos luxos e dos prazeres. Ahi mesmo Luiz passou uma vida penitente e santificada, não se deixando corromper pelos perniciosos exemplos.[...]

Era chegado, finalmente, o momento decisivo, em que Luiz devia revelar a sua piedosa mãe as promessas feitas a Deus e sua firme resolução de entrar na Companhia de Jesus.

Sua extremosa mãe inundou-se de uma santa alegria com esta revelação. 0 mesmo, porém, não aconteceu ao Marquez de Castilhão.

SEU PAE ficou transportado de colera e o ameaçou de rigorosos castigos. 
Luiz amava extremecidamente SEU PAE e o respeitava. Estava sêmpre prompto a cumprir suas ordens, desde que não estivessem em opposição ás de SEU PAE CELESTE.

O MARQUEZ de Castilhão, vencido afinal por seus amigos, resolveu dar a licença tão ardentemente implorada por seu amoroso filho. Essa illustre familia volta a Italia, e ahi ainda Luiz vae deparar com novos obstaculos na realização de seu projecto.[...]

SEU PROPRIO PAE retratou o consentimento dado, cobrindo-o de exprobações, improperios e de ultrajes.

Luiz, sempre respeitoso e firme como um rochedo batido por encapelladas ondas, por sua humildade desarmou SEU PAE, conseguiu nova permissão, de conformidade com suas vivas aspirações.

SEU PAE, banhado em lagrimas Ihe disse: "Meu filho, [...] eu não te detenho mais; vae para onde o Senhor te chama, e praza aos céos que sejas feliz!"

Sem mais demora, Luiz partiu para Roma, ahi visitou os logares repletos das maiores recordações christãns,

FOI BEIJAR OS PÉS DO PAPA Sixto V, implorando sua bençam PATERNAL, e entrou no noviciado da Companhia de Jesus, na edade de dezoito annos. (ARCIPRESTE FONTOURA)

Numa leitura conjuntural, a repetição de um mesmo item lexical - "seu pae" - tem a função de "mimesis de uma presença" (Zumthor, 1993:200), a saber, a do Estado republicano que direcionou o filho às armas, se separou da igreja e investiu no ensino leigo. Os jesuítas resgatam a tradição romana e o ensino religioso fazendo o Estado envergar à organização da Companhia de Jesus.

Uma leitura adicional da repetição de "seu pae" é colhida com a retomada anafórica pelo aposto "Marquez de Castilhão" que reorganiza o cenário colocando em cena, por meio da "teatralização da palavra" (ZUMTHOR, 1993), outro marquês, aquele que, representando o Estado, autorizou a entrada dos jesuítas no território português, expulsou-os e, posteriormente, se inclinou à resiliência dos jesuítas, os quais atualizam as "recordações christãns". A "ambiguidade retórica" permite o contraponto entre o pai de Luiz de Gonzaga e o "pai/pátria" que tantos empecilhos criaram para a realização da conquista espiritual de Gonzaga e dos jesuítas na América portuguesa. Pela 
"teatralização da palavra", cria-se a "mimesis da presença" do marquês de Pombal e se desconstrói simbolicamente o oponente-Estado, reforçando a missão jesuítica e reestabelecendo a ordem hierárquica por meio do apagamento do rito beija-mão, uma atitude protocolar, e da sobrelevação do rito de beijar os pés do papa, tomado como símbolo de reverência.

A associação com Pombal é colhida no trecho seguinte, em que a repetição do sintagma "lucta" cria um cenário em que disputam Luiz de Gonzaga e seu pai de forma desigual, colocando o poder espiritual e o poder temporal no tatame. A ênfase na desproporção das armas serve para vitimizar e, em seguida, acentuar a força de Luiz de Gonzaga que, apesar de lutar com armas inferiores, vence o oponente que parecia invencível.

O elemento "apenas", em vez de ser entendido como advérbio focalizador no sentido de "somente", se fragmenta pelo ritmo e se desgramaticaliza (em nossa intervenção gráfica separamos a preposição e o nome) gerando a simultaneidade de leituras divergentes como "na forma de penas", no sentido de que o moço era a própria pena leve, pura que era recebida pelo alvo, a Companhia, e como "a duras penas", sinalizando que, com dificuldade, após tantas tribulações, finalmente chegava ao alvo que havia mirado. A esse propósito, há que se levar em conta que Luiz de Gonzaga atualiza a figura de Ignácio de Loyola: ambos têm ascendência nobre, são direcionados à carreira militar e se consagram ao catolicismo. Luiz é um reencontro com a matriz de si (a figura de Loyola), e a sua trajetória, por tabela, reitera o mito de fundação da Companhia de Jesus:

Com os ardores da idade e com o orgulho da força une-se o orgulho da raça, as facilidades da opulência, e tantos outros perigos, aos quaes ordinariamente não resistem os moços na sua idade, e são motivos para se afastarem de Deus e foram entretanto para Luiz de Gonzaga occasião de seus mais bellos triumphos.

NESTAS LUCTAS nas quaes tantos fazem naufrágio - Luiz de Gonzaga só teve de luctar comsigo; - havia porém outro obstáculo maior, e neste terreno o adversário era terrível porque foi seu próprio Pae. 
Trava-se a LUCTA entre o joven adolescente e o velho guerreiro

[que fundara em seu filho as suas mais brilhantes esperanças]

LUCTA desigual,

LUCTA que durou tres anos inteiros,

LUCTA em que o moço nobre fez mais esforços em renunciar á sua corôa e aos cabedais do que outros empregam em adquirir fortuna.

[...] O MARQUEZ, SEU PAE, vencido, entre soluços lhe diz pesaroso e triste: [...] _ sabeis que em vós fundava as melhores esperanças de minha raça, mas já que Deus vos chama, ide, eu vos dou a minha bençam.

Todos os laços se romperão, laqueus contrictus est, e como a seta despedida do arco, procura o alvo e ahi se fixa, o moço virtuoso APENAS é recebido como noviço da Companhia de Jesus, que Jesus se torna a vida única de sua bela alma [...] (MONSENHOR COSTA)

Numa leitura conjuntural, mimetiza-se a oposição entre os bacharéis que os jesuítas procuravam recrutar e os pais, mas também a inocência/ ingenuidade/ inexperiência dos colegiais adolescentes e o mundo dos guerreiros/perigos externos, metaforizado pelo marquês/Estado.

Em um nível mais profundo, a oposição entre adolescente e guerreiro remete ao índio recrutado pelo jesuíta e o colono ou até mesmo o pajé, atualizando a contingência histórica das primeiras décadas da Companhia na América Portuguesa.

Além da oposição adolescente e guerreiro, o trecho acima cria a oposição entre jovem e velho, no sentido de novo e ultrapassado, respectivamente. $O$ "joven adolescente" é "moço virtuoso" porque não é guerreiro para adquirir fortuna, não é maculado. Por isso, é recebido como noviço da Companhia de Jesus. Apesar e porque a luta foi desigual (Luiz de Gonzaga lutou contra o próprio pai/ "a corôa"), o jovem se transformou em moço virtuoso porque optou pela vocação religiosa.

A metáfora de atrito entre pai e filho é usada como exemplo da superação do primeiro que deixa de se sujeitar à família/Estado e se subjulga voluntariamente ao 
cristianismo ditado pelas regras papais, que a Companhia de Jesus se propõe a difundir pelo mundo.

\subsubsection{A mocidade}

A repetição linear do marcador de intensidade "tão", ao ser introduzida pelo conectivo contrajuntivo, recebe acento prosódico diferenciado com o alongamento da vogal nasal que indicamos graficamente pela separação das letras que compõem o modificador. $\mathrm{O}$ acento prosódico sobre o segundo modificador coloca em destaque 0 adjetivo com o qual os jesuítas querem que a plateia identifique o santo ("existência... cheia, excellente e triumphante"), como unidade, manifesta pela reiteração do artigo indefinido do predicativo, a qual integra e o unifica ao Criador, servindo como modelo exemplar para o recrutamento de novas unidades para a construção universal do cristianismo:

A existência de S. Luiz de Gonzaga, que foi

TÃO curta, mas T- $\tilde{A}-O$ cheia,

TÃO transitória, mas T- Ã - O excellente,

TÃO trabalhosa, mas $\mathrm{T}-\tilde{A}-\mathrm{O}$ triumphante,

TÃO enérgica quanto segura, foi UMA oblação,

UMA immolação a Deus,

UMA hóstia viva, que se ergueu dos desertos deste mundo alva e brilhatem e inteiramente consagrada ao Deus Creador. (MONSENHOR COSTA)

A singularidade do santo é marcada por oposição à mocidade que esbanja os valores do mundo (força, saúde, talento, inteligência, riqueza, pudor, generosidade) e declina os dons naturais (dons da graça, religião, piedade, fé, caridade, esperança, pureza). O foco nas máximas do mundo impede que se deslize o olhar para os dons naturais, como se observa na disposição paradigmática dos substantivos: 
_ A virtude é toda a beleza interior do homem, segundo Santo Agostinho, interioris hominis pulchritudo. E foi desta beleza que Deus se agradou.

A MOCIDADE ILLUDIDA

pelas máximas do mundo

a [beleza] perde -

força,

saúde,

talento,

intelligencia,

riquezas,

pudor,

generosidade,

tudo ella esbanja...
...ESTA POBRE MOCIDADE ILLUDIDA com os dons naturais

se despoja também dos

dons da graça:-

religião,

piedade,

fé,

caridade, esperanças eternas, pureza d'alma nada fica intacto.

Pois bem, em lugar de dissipar, Luiz de Gonzaga

\section{AJUNTA, GUARDA, CONSERVA e AUGMENTA}

cada vez mais os seus ricos cabadaes. (Monsenhor Costa)

$\mathrm{Na}$ leitura do segundo bloco textual o adjetivo "pobre" sintetiza o resultado do processo de esbanjamento, ao qual segue a lista de dons naturais (repetição de substantivos abstratos) que se perdem pelo caminho. Se a ilusão da mocidade é expressa por listas de substantivos abstratos, o projeto racional que singulariza o santo emerge da repetição da categoria verbal cuja sequência linear permite a leitura temporal e de causa-efeito ("ajunta, guarda, conserva e augmenta"), mas que pode ser lida também de forma especular: ele junta e, com isso, aumenta; ele guarda e, com isso, conserva.

A série de reiterações do sintagma nominal "moço santo" recebe diferentes entoações prosódicas. A construção predicativa "Foi um moço santo" é colocada em foco pela exclamação "moço santo!" e, em seguida, é posta em xeque pelo fracionamento do sintagma para a construção da frase interrogativa que põe a dúvida sobre a correlação entre mocidade e santidade: "um moço pode ser santo?" A resposta vem na 
desconstrução da representação negativa da "mocidade" enquanto fase de tentações, principalmente da carne, por isso o jovem deve ter por modelo a pureza de Cristo.

Mas Deus ama uma mocidade específica. Entre tantas victimas, hóstias de louvor, Deus ama Cristo "a hóstia viva da Cruz - a immolação do Cordeiro sem mancha". $\mathrm{Na}$ sequência, Deus ama o "homem Santo, o homem puro e innocente":

Os altares sagrados ardem em combustão de victimas e as primicias dos campos e dos animaes - expiram e se consomem na pyra immensa do amor e da submissão ao seu Creador. - São sacrificios, immolações, holocaustos, HOSTIAS e victimas offerecidas ao Altissimo em todos os pontos da terra e atravéz de todos os tempos.

ENTRE TANTAS VICTIMAS, porém, carissimos irmãos,

ENTRE TANTAS HOSTIAS DE LOUVOR, nenhuma agrada tanto o Senhor, como a HOSTIA viva da Cruz - a immolação do Cordeiro sem mancha.

Mas depois desta o Todo Poderoso prefere o que ha de mais perfeito no Universo, o homem, o homem Santo, o homem puro e innocente, offerecendo toda a sua vida, sem condições nem reservas em olente sacrificio em sua honra e em seu louvor.

$\mathrm{Na}$ lei nova entre milhões e milhões de HOSTIAS que se offereceram assim á Deus fulge justamente e brilha o moço Santo, cuja festividade celebramos, S. Luiz de Gonzaga - que foi uma verdadeira HOSTIA viva, santa e agradabilissima ao Senhor. Hostiam vivam, sanctam Deo placentem.

$[\ldots]$

É pois no coração que se prepara a verdadeira victima para o holocausto, victima que segundo o sacerdocio de Arão devia ser sem mancha, integra e sã - Pela immolação porém a victima se santifica e torna-se com rigor uma HOSTIA santa. Hostiam sanctam.

O patrono do colégio é colocado praticamente no mesmo plano de Cristo, senão projeção, quase como se fosse um prolongamento; afinal, o Cordeiro sem mancha é o "homem Santo, o homem puro e innocente", predicativos atribuídos a Luiz de Gonzaga, reforçados pela expressão latina hostiam vivam, sanctam Deo placentem. 
A sedução de Deus e da plateia se dá pela formulação da pergunta: "quem é que pode resistir ao encanto de um moço?", e pela resposta construída pela repetição do item "moço" que nucleia estruturas relativas que descrevem virtudes que o alinham e o fazem assemelhar-se a Deus. Traços distintivos como olhos límpidos, fronte serena, corpo casto, doçura, paz e suaves harmonias, retomam o modelo cultural do cortesão, cuja designação remonta dos primeiros colégios da Companhia de Jesus (HANSEN, 2001. Mas que moço é esse que se assemelha a Deus? É o "moço christão", especificado pela atualização fornecida pela coordenada dêitica "este" que remete à origem do discurso, provavelmente um crucifixo ou uma bíblia indicada pelo pregador para gestualmente identificar a figura do próprio Cristo, moço que amou Deus e que foi amado por Deus:

Foi um MOÇO SANTO - designação que o caracterisa [...]

MOÇO SANTO! UM MOÇO pode ser SANTO?

Alerta! Caríssimos jovens de Ytú!

Alerta, vós principalmente que recebeis

neste Aeropago das letras,

neste Cenaculo dos espíritos,

uma educação solida e primorosa,

alerta vos digo, porque lá fora n'um mundo máu e perverso,

lá fora no seio de uma sociedade pervertida e quase pagã,

uma calumnia negra vos espera para despojar a vossa MOCIDADE, as primícias

tão preciosas de vossa vida, denoda a sua aureola, de todo o seu explendor.

Esta calumnia é que a MOCIDADE é a idade do vicio e de todas as loucuras humanas, que nella se pode gosar impunemente de tudo - mergulhando-a sem medo, sem medida nem rebuço na lama de todas as paixões.

$[\ldots]$

Oh! Sim, o dever do MOÇO CHRISTÃO é desmentir pela sai vida tão nojenta calumnia seguindo os passos de Stanislau, de Berchmans e de Luiz de Gonzaga [...]

Vós sabeis que DEUS AMA A MOCIDADE e a MOCIDADE acha justamente sua segurança em amar a Deus, unir-se a Elle e viver dele. DEUS AMA A MOCIDADE com sua frescura [...]

Quem é que pode resistir ao encanto de 
UM MOÇO [que soube se conservar como Deus o creou,

UM MOÇO [que ostenta em seu ser[...] todos os traços admiráveis da imagem de seu creador, UM MOÇO enfim [cujos olhos límpidos, fronte serena e corpo casto só respiram doçura, paz e suaves harmonias.

_ A graça, a candura, a inocência e a integridade desta beleza dos anjos, infeitiça e attrahe o coração divino.

É assim, caríssimos irmãos, que nos aparece S. Luiz de Gonzaga

- DEUS AMOU ESTE MOÇO E ESTE MOÇO AMOU MUITO A DEUS.

Luiz de Gonzaga viveu pouco na terra, viveu MOÇO e MOÇO ainda morreu, mas viveu bastante para não ser um mytho, nem um vulto fantástico.

A SUA physionomia sypmphathica e marcial.

SEU porte garboso,

SEU gesto de fino aristocrata,

SUA voz agradável,

SUA inteligência viva

e tantos outros dotes naturaes que herdou de SEU berço ilustre, dão-lhe tal relevo que o tornam alvo de uma admiração bem justa e merecida.

Continuando a observá-lo, vós vereis que

AQUELLA fronte cândida,

AQUELLES olhos puros,

AQUELLE ar modesto e cheio de recatos,

AQUELLA conversação elevada e sempre nobre [...]

derramam em toda a sua pessoa uma tal claridade que só possue verdadeiramente um MOÇO SANTO. (Monsenhor COSTA)

A identificação do paradigma de moço cristão é o ponto de partida para a formulação do paralelismo com o patrono do colégio - Luiz de Gonzaga, cuja trajetória ${ }^{68}$ ecoa a de Cristo. A reiteração dos pronomes possessivo e demonstrativo de 3a . pessoa, construção de uma tradição gestual e vocal, desloca os traços distintivos que caracterizam Luiz de Gonzaga para a figura do primeiro moço cristão, que somente um

\footnotetext{
${ }^{68}$ Em discurso anterior, houve a emulação de Loyola e agora a de Cristo.
} 
moço santo possui. Trata-se da proposta de imitação da vida de Cristo por meio da teoria pedagógica do exemplo. A esse propósito vale lembrar o uso do expediente do exemplo nas práticas jesuíticas no período colonial:

"O 'exemplo', a exibição concreta de virtudes, é considerado excelente estímulo e paradigma poderoso e válido para a prática cristã. Mas o poder do 'exemplo' não conhece uma só direção. Ele é uma espécie de forma neutra e vazia que pode ser preenchida para o Bem ou para o Mau." (NEVES, 1978:58)

O trecho acima que se abre com o sintagma nominal "moço santo" na função predicativa se fecha com o mesmo sintagma nominal na função de sujeito, mas na posição linear de predicado sentencial. Absorvendo e sintetizando o predicado, o sujeito - na posição de predicado - remete ao batismo que se pretende emular com o "Echo das festas collegiaes", conjuntura da pregação do panegírico.

\subsubsection{A educação}

Por meio da figura do santo, as pregações dão exemplo e testemunho aos jovens alunos. Para louvar o santo e tomá-lo como exemplo, os oradores estabelecem uma série de construções de oposição entre virtude e vício, temência a Deus e pecado, glória e lutas. Esse efeito de sentido é conseguido na disposição reiterativa e gradativa de um item lexical: homens $>$ homens grandes $>$ homens uteis á sociedade. A repetição do termo "homens", acrescido do modificador restritivo "grandes" e do modificador apositivo "uteis á sociedade" cria o efeito de isolar o termo e congelá-lo na memória, para marcar a dimensão social da Companhia de Jesus:

"Não, os exemplos de Luiz Gonzaga não são antiquados; antes hoje mais que nunca devem ser gravados nos corações d'aquelles, que, desejamos, cheguem um dia a ser verdadeiramente HOMENS, HOMENS grandes, HOMENS uteis á sociedade; 
[porque esses exemplos são diametralmente opostos á corrupção moderna,

[que dos homens faz pouco menos que brutos, e á suberba insensata que soffrega de liberdade quebra os diques da subordinação para se atirar nos braços da libertinagem e da licenciosidade". (Pe. FIALHO)

O discurso é voltado para negar à figura jesuíta a representação do velho, do sisudo e do ultrapassado elaborada pelos revolucionários e sintetizada pela imagem do hábito negro por Stendhal, os quais associavam a Companhia de Jesus ao Antigo Regime. A dissociação da imagem negativa é realizada pelo alinhamento dos jesuítas ao projeto civilizatório que estava em marcha e que encontrava ressonância na dimensão social da Companhia de Jesus. Na chave de leitura jesuítica, esse programa civilizatório visava a aperfeiçoar o ser humano segundo os preceitos religiosos. Rejeitando a distinção entre sociedade civil e sociedade religiosa, toma-se como pressuposto que a "educação livre" desestrutura os homens, os quais implodem pela ausência de uma canga - cristandade -, como sugere a enfiada de substantivos abstratos e de adjetivos aparentemente desconectados sintaticamente, evocando, por meio da voz e do gesto amplificadores, a fragmentação dos homens e a desordem, que procuramos capturar pela distribuição gráfica:

Ah! Desterrai da educação scientifica da mocidade os princípios religiosos sob pretexto de não vos impor á liberdade de vossos filhos na escolha da religião [...] e vel-os-eis copiar fielmente o quadro assustador [...] daquelles homens

$$
\begin{aligned}
& \text { identificados com a } \\
& \text { impiedade, } \\
& \text { malícia, } \\
& \text { devassidão, } \\
& \text { avareza e } \\
& \text { torpeza, }
\end{aligned}
$$

repassados

de inveja,

de ambição, 
de perversidade,

de fraudes e

de vinganças,

alcoviteiros,

alumniadores,

exosos a Deus e aos homens,

porque

blasphemos,

altivos,

suberbos,

machinadores de delictos,

estolidos,

desamorados,

incapazes de qualquer sentimento

de piedade,

de lealdade e até mesmo

de humanidade.

E esse é, senhores, o paradeiro fatal, a que vão tombar os homens crescidos sem a ldea de religião e de Deus [...] Mas como pode assentar em um homem intelligente e livre a ldea do dever sem antes se convencer da subjeição natural a um ente a si superior? (Padre FIALHO)

A avalanche de substantivos e adjetivos, acompanhada da gestualidade do orador, tem por efeito, no imaginário da recepção pública, a criação de uma figura deformada e desprezível daqueles que não são regidos pelos princípios religiosos. Os cacos recolhidos só ganham forma com a obediência a um ser superior. A sujeição a um ser superior é uma forma de se lançar fora de si como requisito para a união com Cristo, o que configura o sacramento da ordem.

$\mathrm{Na}$ chave de leitura do contexto sócio-histórico em que o discurso foi produzido e proferido, a crítica à desordem se dirige às investidas republicanas no ensino laico "esse verme roedor do ensino leigo e radicalmente atheu" (Arcipreste FONTOURA) indiciada na repetição de sintagmas preposicionados que marcam a disseminação desse 
tipo de educação. O mal à humanidade deriva do laicismo que está nas teorias do racionalismo que colocaram no mercado folhetins, brochuras, espetáculos, livros, romances realistas e naturalistas, e artes liberais:

Mas que dique póde levantar contra o diluvio universal da volúpia e da podridão, [que alaga o mundo hodierno soçobrado por folhetins e brochuras inspiradas na pornographia mais hedionda, por espectaculos e festins moldados pela impudência mais asquerosa, por livros dictados em uma litteratura forjada no realismo, naturalismo e sensualismo, a retractar com a desfaçatez mais sem nome o carnalismo mais desbragado,

pelas artes liberaes paganizadas a endeusar em solemnes apotheoses o vicio e 0 crime?

$[\cdots]$

Nas escholas, nas academias, nas universidades,

são attrahidos os erros os mais abominaveis,

os systemas os mais perniciosos, as doutrinas as mais subversivas, $\mathrm{e}$ subversivas á própria dignidade humana.

$[\ldots]$

_ À vista do que, eu vos pergunto, senhores, julgais vós por ventura que a mocidade moderna, só porque allumiada pelas theorias perniciosas do racionalismo e do livre exame esboroados já nos systemas positivista, materialista e evolucionista subversivos da dignidade humana, é a que há de desmentir a palavra inspirada do escriptor dos Proverbios: "Adolescens juxta viam suam etiam cum senuerit non recedet ab ea"?(Padre FIALHO)

É na brecha da lei que os jesuítas vão encontrar autorização para a entrada em campo dos "soldados de Cristo" que se dedicam a reconquistar o território espiritual: "A 
Constituição da nossa extremecida patria, garante-nos ampla liberdade de ensino primario, secundario e superior"(Arcipreste FONTOURA).

A liberdade de ensino garantida pela Constituição Republicana é o espaço necessário para que a voz autorizada dos pontífices possa continuamente - aspecto verbal marcado pela preposição diante do infinitivo - dar prosseguimento às ações jesuíticas na guerra do bem contra o mal:

Eis o porque do levantarem tão amiúde a voz auctorizada os Pontifices Romanos; postos por Deus como atalaias da verdade e do bem entre os homens,

A ATEAR sempre mais o zelo dos pastores ecclesiasticos,

A UNIR as forças do clero em associações de educação,

A DESPERTAR nos fieis a ldea do próprio dever,

A ABALAR a inércia,

A ALENTAR a operosidade,

A COROÇAR a dedicação,

A FECUNDAR os sacrifícios pelo bem da mocidade;

e eis também o porque do verdes sempre e por toda a parte as phalanges aguerridas dos escolhidos do Senhor

A BATALHAR com denodo na guerra do bem contra o mal,

Affanarem-se por educar religiosamente a mocidade. (Padre FIALHO)

No âmbito da metáfora bélica, o patrono do colégio - Luiz de Gonzaga é o soldado de Cristo que se coloca em campo não apenas como aquele que resiste arduamente, mas como aquele que avança, desbarata o inimigo conquistando-o espiritualmente. A formação jesuítica, completa que é, pode fazer do jovem o militar espiritual, na figura do soldado de Cristo cujos instrumentos de luta são de outra ordem: espada da verdade, escudo da fé e elmo da esperança, instrumentos que constituem a armadura completa 
de caridade. Parodia-se a epístola do Apóstolo Paulo aos Efésios"69: "Portanto, tomai toda a armadura de Deus, para que possais resistir no dia mau e, havendo feito tudo, ficar firmes."

Rodeado Luiz, como os mais homens, de tantos inimigos [...],

EMPUNHA (consoante o aviso do Apostolo) a espada da verdade,

SOBRAÇA o escudo da fé,

COBRE-SE do elmo da esperança,

REVESTE o arnez da charidade,

e assim armado

não só RESISTE aos amiudados assaltos da hoste infernal,

mas a INVESTE elle o primeiro,

mas a LEVA DE VENCIDA,

mas a RENDE,

mas a DESBARATA em modo tão cabal, que (cousa muito para admirar em um jovem de character ardente, de temperamento sanguíneo, e criado entre as delicias das côrtes) que sequer o mais leve phantasma não lhe perturba a imaginação... (Padre FIALHO)

A sequência de verbos flexionados que tem como sujeito sintático e sujeito lógico Luiz de Gonzaga explicita o agente a ser tomado como exemplo: "E por mim; para que me seja dada, no abrir da minha boca, a palavra com confiança, para fazer notório o mistério da fé" (Efésios, 6:19). A "palavra com confiança" é aquela que se expressa pelo Verbo, elemento que predica as ações do pontífice e do santo Luiz de Gonzaga. Em

69 “Portanto, tomai toda a armadura de Deus, para que possais resistir no dia mau e, havendo feito tudo, ficar firmes. Estais, pois, firmes, cingindo-vos com a verdade e vestindo-vos da couraça da justiça. Calçai os pés com a preparação do evangelho da paz; embaraçando sempre o escudo da fé, com o qual podereis apagar todos os dardos inflamados do Maligno. Tomai também o capacete da salvação e a espada do Espírito, que é a palavra de Deus." (Efésios, 6:1317) 
outras palavras, a reiteração de predicados verbais reforça a proclamação da mensagem divina: o Verbo.

Ao atribuir ao santo valor pedagógico, explora-se o perfil resiliente às investidas dos propugnadores do ceticismo. Nesse sentido, a figura do santo é usada tanto para acentuar uma distinção - moços iludidos - por meio da crítica à educação laica responsável pelos perigos que desviam os moços da virtuosidade e pela falsa representação do jesuíta como antiquado e ultrapassado, quanto para instaurar a imagem realista do jovem mesmamente daqueles presentes no auditório.

\subsection{DO DISCURSO AO CARDEAL ARCOVERDE}

Na "Semana de festejos em honra a São Luiz Gonzaga", organizada pelo Colégio São Luiz, homenageou-se o primeiro cardeal brasileiro, D. Joaquim Arcoverde de Albuquerque Cavalcanti, nomeado pela Cúria Romana para fazer frente ao fim do regime do Padroado e ampliar a ação da igreja no Brasil.

Para a ocasião festiva, o colégio convidou o Dr. Brasílio Machado para proferir discurso em sessão solene no dia 2 de julho de 1906 honorificando o recém-nomeado Cardeal, figura que fizera parte do corpo docente do colégio e que passara a integrar o senado cardinalício, dando continuidade à missão civilizadora de José Anchieta, tido como "um dos fundadores de nossa nacionalidade e o infatigável semeador de Jesus na catechese do Brasil".

Apesar de ser representante do regime de governo que optou pela separação entre Igreja e Estato, o bacharel em direito e conselheiro da Instrução Pública de São Paulo realizou pronunciamento alinhado às coordenadas ultramontanas que, por reação ao pensamento laico racionalista e cientificista que se seguiu à Segunda Revolução Industrial (MICELI, 1988), buscavam fortalecer os laços de obediência à Santa Sé. A convergência de ideias do conselheiro da Instrução Pública a respeito das atividades confessionais tem o poder simbólico de legitimá-las, ao mesmo tempo em que

deslegitima as práticas do ensino laico do Estado que o conselheiro representava. É 
como se o conselheiro, como rendição/conciliação, jogasse a toalha sobre 0 altar religioso devolvendo o poder a quem de direito. Com efeito, a tópica que move o discurso do Dr. Brasílio Machado é a rendição/conciliação, que se desenvolve por meio da exploração de temáticas como instituição, vaso e comunhão.

A púrpura, vestuário de reis e, por extensão, a dignidade cardinalícia, se transmuta na figura do mestre que, por sua vez, representa e é parte da instituição que preza pela comunhão entre religião e pátria. Esta instituição é a um só tempo a Companhia de Jesus e o colégio de S. Luiz de cujo corpo docente fez parte o recém-nomeado cardeal, homenageado pelo colégio na semana dos festejos do santo:

Com effeito,

A PURPURA

[que tão á feição vos veste, não pode nos encobrir e esconder os contornos do MESTRE, erudito, bondoso, singelo

[que [...] foi parte precípua do corpo docente desta instituição;

INSTITUIÇÃO

[que representa nos seus mais austeros intuitos a confraternisação sincera da religião e da pátria.

AS MÃOS

[que ora de tão alto nos abençôam, ainda sentimo-las carregadas daquelles muitos carinhos

[que, na geração de numerosos discípulos, deixaram perenne e viva a MEMORIA de vosso nome.

VOSSO OLHAR, bem se percebe ainda,

VOSSO OLHAR nos procura e nos acompanha,

num volver ancioso de saudade, por estes sítios tão amados e tão familiares, despertando de todos os lados a suavidade de uma RECORDAÇÃO amiga.

AINDA se escuta AQUI

VOSSA PALAVRA, 
a REPERCUTIR DE CORAÇÃO EM CORAÇÃO, preciosa na lição de vosso saber, quente á inspiração de vosso patriotismo, convincente pelos estímulos de vossas virtudes exemplares e edificantes.

Há por quinze annos, ESTE COLLEGIO vos recebia. [...] Oh encantadora phase de nossa vida, exclamastes mais tarde, quando quebrada a vossa claurura voluntaria [...]

Mas, AINDA ALLI vos dispertaram as prementes inquietações do VOSSO ZELO APOSTÓLICO.

Affligia-vos a perspectiva do atheismo pratico, que vinha crescendo minaz e vigoroso. Urgia então, como urge agora, combater, na frase de Pio $\mathrm{X}$, o espírito que insufla a sociedade contemporanea, na doentia avidez dos haveres materiaes, ignorante das verdades divinas, mas insolentemente ensoberbecida por uma sciencia de todo perniciosa, e mais ainda atascado na torpeza dos vícios destruidores da vida. (BRASILIO MACHADO)

A repetição única do sintagma nominal "vosso olhar" tem a função de desdobrar o olhar, separando e mesclando, o olhar do mestre e o do cardeal, e o olhar da instituição e o do colégio, em uma operação combinatória. As duplicidades do olhar, que "procura" e "acompanha", recuperam o "carinho" e a "graça divina" atribuída pelas mãos e proferida pela palavra. Nesse processo de teatralização gestual e vocal procura-se resgatar a memória da tradição religiosa como "zelo apostólico" para conquistar espiritualmente e vencer o ateísmo.

Os blocos embreantes "ainda... aqui" e "ainda alli" deslocam e pontuam a imagem do cenário ao mesmo tempo em que presentificam e marcam a permanência da prática: aqui, neste lugar (Colégio) e neste momento se escuta a vossa palavra dada em outro lugar (senado cardinalício) e em outro momento, o período em que atuava no Colégio. Do mesmo modo, "ainda alli... o vosso zelo apostólico", se verificou no passado e se verifica no presente. Ao neutralizarem as categorias de pessoa, espaço e tempo, e denegarem a instância do enunciado (FIORIN, 2005), os embreantes assinalam o pervagar da palavra e do zelo apostólico do cardeal, do(s) bispo(s), do(s) mestre(s), (do(s) santo(s), do papa, de Cristo, e da instituição dos jesuítas, que une os diversos pontos (NEVES, 1978) e garante suas continuidades. 
A imagem do Cardeal como vaso faz referência a outro símbolo sagrado, que serve para consagrar o vinho, que se converte em sangue sagrado de Cristo:

Deus tomou entre suas mãos santificadoras O VASO,

[que o mundo tivera por perdido e desestimado num canto desta casa, e quiz afeiçoal-o em VASO DE HONRA,

VAS IN HONOREM;

EM VASO PRECIOSO,

VAS PRETIOSUM,

[por cujas bordas opulentas bebe a bocca dos sábios;

EM VASO DE ELEIÇÃO,

ambula da embaixada de seu nome aos povos do Brasil, ut portet nomen meum coram gentibus.

E por duas dioceses, ao aceno de vosso báculo,

se renovou a acção da fé,

abriram-se novas sementeiras ás vocações ecclesiasticas, descortinaram-se outros campos de trabalho espiritual,

medraram novas instituições religiosas,

responderam, numerosos e abnegados operários da vinha,

semeiou-se mais assídua a palavra divina...

e, por vossas mãos, desceu sobre a imagem da Apparecida,

nas festas do jubileu do dogma da Immaculada,

o primeiro diadema com que a Egreja consagrou entre nos a secular devoção á Protectora do Brasil.

Deus chamou-vos, Eminentissimo Senhor, para destinos admiraveis,

VAS MIRABILE, para vestir-vos, qual o primeiro Pontifice da antiga Lei, com um paludamento de gloria, stolam gloriae,

e cingiu-vos das grandes virtudes,

IN VASIS VIRTUTIS.

Sim! que na Purpura cardinalicia sente-se uma MAGESTADE única;

- grandeza sem concorrentes d'entre as magestades profanas,

porque é a magestade que sómente a Egreja pode constituir e communicar. 
É a segunda magestade do Papado, disse-o um preclaro Bispo.

A Purpura recebe, de mais perto e mais ao vivo, os reflexos da sublimidade da sede de Pedro, sendo, como é, o Sacro Collegio um Conselho de Pedro.

Quem é Pedro?

O chefe da Egreja

[que, única e só, é a verdadeira sociedade das almas na luz e no amor divinos.

É, como Vigario de Christo,

a representação immediata e visível do Pontificado divino,

o signal manifesto e efficaz da presença de Deus,

do Deus,

[que na pessôa de Pedro, a se reproduzir, de Pontifice em Pontifice, nella falla,

nella doutrina,

nella governa.

Christo é Pedro invisível,

como Pedro é Christo visível na universal direcção da egreja.

É a fórma tangível da mesma Pedra,

[de que Christo é a fórma e a substancia intangíveis,

pedra angular

[que sustenta inabalável o edifício da egreja.

Em summa, formando com o Christo um só grau de hierarchia,

Pedro é o supremo gerarcha,

soberano

[que em si contém e dispõe da maior somma de poderes, summa rerum, que jámais o mundo conhecera em outro solio. (BRASILIO MACHADO)

A união dos diversos pontos se faz pelo amálgama da paródia da oferenda ("Ele tomou o cálice em suas mãos dizendo: 'Tomai e bebei todos vós: este é o cálice do meu sangue, o sangue da nova e eterna aliança, que será derramado por vós e por todos para a remissão dos pecados'.") com a paródia do versículo de Timóteo 2.20.21 (“Ora, numa grande casa não somente há vasos de ouro e de prata, mas também de pau e de barro; uns para honra, outros, porém, para desonra. De sorte que, se alguém se purificar 
destas coisas, será vaso para honra, santificado e idôneo para uso do Senhor, e preparado para toda a boa obra".), com vistas a criar a cerimônia sacramental que purifica os povos do Brasil: "Deus tomou em suas mãos santificadoras o vaso... e quis afeiçoal-o em vaso de honra, vas in honorem, em vaso precioso, vas pretiosum, por cujas bordas opulentas bebe a bocca dos sábios; em vaso de eleição".

As expressões latinas conferem relação com o corpo místico da igreja, por ser a língua escolhida da liturgia. O final, o vaso já não recebe mais tradução em português: vas mirabile e in vas virtutis expressam a simbiose linguística entre o corpo da Igreja e a língua escolhida para a manifestação da Palavra.

A reiteração seguida da nomeada versão latina do sintagma nucleado por "vaso" configura o ato ilocucionário da remissão dos pecados e da purificação do povo brasileiro realizada por Deus, e traduzida em português pelo orador, por reconhecer o empenho dos bispos diocesanos que "arrumaram a casa". Renovando a ação da fé, semeando a palavra divina, aumentando campos de trabalho espiritual, o povo brasileiro se transformou em vaso para honra, o que se efetivou pela coroação da imagem de Aparecida, alçando-a a Protetora do Brasil, e pela nomeação cardinalícia sacramentada como vas mirabile e in vasis virtutis.

Ao povo brasileiro foi confirmada a consagração - em vaso de eleição - da "purpura cardinalicia", símbolo da grandeza suprema e única da majestade que "sómente a Egreja pode constituir e communicar", e que desbanca todos os demais poderes terrenos, mais especificamente, aqueles em que os homens não se emparelham ideologicamente com a Igreja ${ }^{70}$. A repetição de "purpura" guia a construção tópica do parágrafo e a concepção de que é ela que recebe os reflexos da sublimidade da "séde

\footnotetext{
${ }^{70}$ A crítica presente na contraposição "magestade única" X "magestade profana" destaca a separação entre o sistema espiritual e temporal.

O decreto 119-A do dia 07 de janeiro de 1890 proibia a intervenção da autoridade federal e dos Estados federados em matéria religiosa, consagrava a plena liberdade de cultos e extinguia o padroado. Um ano antes, a Igreja se manifestava no Concílio Plenário Latino-Americano, realizado em Roma, sob a liderança do Papa Leão XIII e com a presença de bispos, arcebispos e sacerdotes brasileiros, na intenção de fortalecer os laços com os prelados da América Latina, na missão de aprofundar a romanização, propagar o catolicismo ultramontano em todas as camadas sociais, inclusive daquelas que ocupavam posições de destaque em cargos públicos.
} 
de Pedro". A púrpura cardinalícia, com assento no Sacro Collegio, se assenta no Colégio de S. Luiz, onde o cardeal desenvolveu sua vocação religiosa para assumir o posto no Conselho de Pedro.

Emulando o catecismo, se coloca a questão: Mas, afinal, quem é Pedro? A resposta é doutrinária: Pedro é Chefe da Igreja, Pedro é Vigário de Christo, Pedro é Cristo visível e Cristo é Pedro invisível. Pedro, que se reproduz de pontífice em pontífice, é a transubstanciação de Cristo, e por meio do qual Cristo fala, doutrina e governa. Por esse viés, o cardeal, com assento no Conselho de Pedro, reproduz a fala, a doutrina e a governança cristã.

A governança cristã se desdobra nas ações do Cardeal, que visam a barrar a perspectiva do ateísmo, das novas teorias científicas, do liberalismo e reestabelecer a ordem com a adoção de medidas que concretizam os ideais ultramontanos de fortalecimento da Igreja, como sugere a sucessão de verbos no gerúndio:

E, successivamente, outros actos se compaginam, do mesmo poder supremo, distribuindo o Brasil em novas dioceses por nova hierarchia ecclesiastica, ampliando ou confirmando privilégios, decretando medidas de disciplina, promovendo a reunião de concílios, fomentando a obra dos seminários, insistindo pela diffusão da boa imprensa, abençoando a organisação das forças da acção catholica, estimulando o progresso da fé e piedade christan, tudo no pensamento de estabelecer e dilatar no Brasil a realeza do Christo. (BRASILIO MACHADO) 
Dando continuidade à reforma do clero iniciada pelo bispo Dom Antônio Joaquim de Melo e à ação moralizadora do bispo D. Lino Deodato Rodrigues, o Cardeal dava a tacada derradeira para a perpetração do ideário católico no seu processo de romanização, alinhando a Igreja de São Paulo com a Cúria Romana.

A credencial para a romanização estava na investidura divina do cardeal que é ex-clamada reiteradamente, como "faculdade mais augusta", "poder mais incomparável", "funcção nobre e tremenda", encerrada na unicidade da "ordem pontifical". A reiteração de apostos introduzidos pelo artigo definido que enfatiza e universaliza o único e a sequenciação de orações exclamativas produzem o eco da unicidade:

E sobretudo, que faculdade mais augusta,

que poder mais incomparável, que funcção tanto mais nobre quanto mais tremenda,

essa de designar por seus sufrágios, á investidura divina, ao Christo, unico da ordem pontifical,

o Successor do Principe dos Apostolos,

o Chefe da egreja,

o Pontifice romano,

a voz egrégia, impeccavel, [que doutrina o mundo,

o centro fecundante da santidade,

a mão soberana [que abençôa ou castiga, para o tempo e além do tempo, para o espaço e fora do espaço,

báculo [que reune o rebanho universal dos fiéis,

rocha [em que furiosas se quebram as insubordinações do mundo,

luz [que dispersa as negras alluviões do erro,

piloto [que norteia, das praias neblinosas da terra para o porto limpido do ceo, a barca insubmersível dos pescadores d'almas.

Eis que D'ORA EM DIANTE, Eminentissimo Senhor, O BRASIL

VAE TER, honra singular até agora em toda a America Latina,

VAE TER, com a vossa presença,

o direito de assento nos culminantes conselhos da Egreja, 
um ministro solicito de seus interesses religiosos perante a Curia, um voto na escolha do successor de Pedro,

um vinculo a mais de pressurosa obediência e de entranhado amor á Santa Sé,

de sorte que seja de momento a momento

mais intima a COMMUNHÃO entre a religião e a pátria;

COMMUNHÃO nutriente que mais deve exaltar e defender as legitimas preoccupações de nossos destinos, como convem a um POVO, que como o nosso, deu o primeiro passo, arrimado á cruz; CRESCEU Á SOMBRA DA CRUZ;

COMMUNHÃO tanto mais instante, quanto se nos afigura urgente a reposição do Christo, no proêmio de nossas leis,

nas salas de nossos tribunaes,

na estructura e orientação de nossas instituições,

no domicilio de nossas famílias,

nos programmas de nossas escolas,

nos brasões de nossa bandeira

como á frente de nossa nação!

$[\ldots]$

Quebremos, pois, e de animo resoluto, a violência caudalosa dos systemas e das seitas que forcejam por nos afastar de Roma, para perdermos o rumo de Deus. A CAUSA DO BRASIL SE DEVE CONJUGAR Á CAUSA DA RELIGIÃO. (BRASILIO MACHADO)

A expressão "d'ora em diante" introduz a referência à oralidade do discurso para marcar o momento em que o Brasil passa a ter um assento no senado cardinalício. A reincidência do artigo indefinido ("um ministro", "um voto", "um vinculo") assinala a unidade, que é ao mesmo tempo termo de comparação entre grandezas da mesma espécie (um entre vários) e termo que explicita a formação de um todo completo ${ }^{71}$.

A forma do todo completo é recuperada pela consagração da "comunhão", termo que se repete para congregar religião e pátria, assinalando a ideia de terra prometida e abençoada porque "cresceu á sombra da cruz". Para além da evocação da

\footnotetext{
${ }^{71}$ FERREIRA, Aurélio. Novo Dicionário Aurélio da Língua Portuguesa, Rio de Janeiro: Nova Fronteira, 1986:1738.
} 
representação teatral da primeira missa realizada em solo americano, o termo "cruz" é usado para marcar "que a terra é efetivamente cristã" (NEVES, 1978:78) e que o povo que aí cresceu foi fecundado e batizado pela palavra civilizatória, graças à missão catequética de José de Anchieta, reconstruído pela palavra arquitetada no século XIX como um "dos fundadores de nossa nacionalidade".

A naturalização da cruz em terra brasileira requer o afastamento do vaso em desonra que representa as seitas e os sistemas que declinam o poder papal (o ateísmo dos liberais e positivistas do momento da enunciação marcado pelo advérbio "ora") para que se possa recuperar o vaso em honra (a religião), por meio da reposição de Cristo nas leis, nos tribunais, nas escolas, na bandeira, na nação, para restabelecer a organização única e solidária das sociedades civil e religiosa, a regência papal, eis que "a causa do Brasil se deve conjugar à causa da religião", ou seja, a salvação da nação brasileira na sua flexão ao tema religioso de matriz romana.

Dentro da perspectiva de análise da estrutura prescritiva da história, proposta por Sahlins, o esquema cultural jesuítico se apropria da vinda do cardeal e the atribui um significado, uma interpretação histórica figural, qual seja a reconstituição do sistema de Padroado ao unir nação e religião pela comunhão, submetendo a primeira à segunda. 


\section{Considerações Finais}

Neste capítulo procuramos mostrar que a sintaxe informa o discurso ideológico jesuítico por meio de expediente linguístico de construção textual que evoca significados "que se identificam mais ou menos a categorias culturais, fundadoras de sentido" (ZUMTHOR, 1993:194). Ainda que os discursos tragam inúmeras outras tópicas que fazem parte do imaginário jesuítico, optamos por restringir nossa atenção àquelas que se manifestaram na forma linguística da repetição.

A evocação de significados pela sintaxe da repetição mostra que os temas e as formas de criação ideológica conformam os dois lados da mesma moeda (BAKHTIN, 2012). Todos os discursos analisados fazem uso da reiteração de partes de sintagmas, de sintagmas inteiros e de frases, compondo e recompondo elementos bíblicos, um processo de repetição, que, ritualizado, recupera o sentido etimológico de repetitio/onis - "ação de subir até a origem".

A repetição verbal e a repetição do Verbo constituem-se em um interdiscurso entendido como "uma rede mnemônica e verbal, que é urdida de forma muito desigual, mas que visa a envolver com seus fios toda a palavra de uma comunidade" (ZUMTHOR, 1993:194). Nesse sentido, todos os discursos e panegíricos se integram uns nos outros e se complementam.

Assim o programa de apagamento da ordem jesuítica pelo processo expulsório que a condenara ao ostracismo foi, por sua vez, desconstruído pela voz jesuítica. $O$ expediente da repetição resgata e fixa essa voz que, anunciada e pronunciada em um rito, se metamorfoseia em ação, por meio da qual os jesuítas se refundam, recuperam suas práticas, reconstruindo imagens e imaginários permansivos, porque, pela voz em rito, são percebidos sensorialmente.

Nesse processo de teatralização vocal e gestual, até aquilo que não é verdadeiro se emanta de verdade, porque "a palavra proferida pela Voz cria o que ela diz" (ZUMTHOR, 1987:75). Exemplo dessa invenção da tradição (HOBSBAWN, 1984) é o 
caso do Padre José de Anchieta recuperado no século XIX como "primeiro nacionalista". Anchieta não se colocou factualmente como nacionalista, pois o imaginário de nação brasileira não existia no período anchietano. Apesar de não ter sido o "primeiro nacionalista", porque não havia lugar para isso, o que fica no imaginário geral é menos o que efetivamente foi e mais o que foi dito/repetido, de modo a fazer vingar no século XIX a associação "Anchieta nacionalista".

A esse propósito, vale salientar que a ostensividade sofre alterações ao longo dos anos. O discurso do conselheiro da Instrução Pública, proferido em dois de julho de 1906 em homenagem ao recém nomeado cardeal, marca, de certo modo, a inflexão do laicismo ao cristianismo, ao pronunciar, da posição de representante da ordem civil, discurso alinhado com as diretrizes ultramontanistas. Com efeito, no ano seguinte 0 orador Carlos de Laet ainda exortava um representante da autoridade civil, mas não definia se vinculado ao poder estatal ou federal. Em 1907, Câmara Leal ainda invoca o Reitor do Colégio, mas não faz menção a nenhuma autoridade civil, e os dois últimos oradores exortam apenas os bacharelandos. Os panegíricos pregados em 1906 exortam os jesuítas e o discurso do Dr. Brasílio Machado exorta apenas o "Eminentissimo Senhor".

O significado cultural atribuído ao evento histórico da vinda do cardeal à cidade de Itu pode ser uma das explicações para a eliminação da exortação de representantes da autoridade civil, mas não explica a ausência de exortação do Reitor do colégio. A partir da visita do Cardeal e com ele, cria-se a onipresença de "uma voz sem lugar" (ZUMTHOR, 1987:94) e de um cenário significante que deixa de ser um espaço comum para ganhar representação mental ( daí não necessitar da ostensividade), lugar em que os imaginários são recuperados, desconstruídos, reconstruídos e, em última instância, negociados. 


\section{CAPÍTULO 4 - COMUNIDADES DE PRÁTICA E USOS LINGUÍSTICOS: O PADRÃO JESUÍTICO DE COLOCAÇÃO PRONOMINAL}

Pronominais

Dê-me um cigarro

Diz a gramática

Do professor e do aluno

E do mulato sabido

Mas o bom negro e o bom branco

Da Nação Brasileira

Dizem todos os dias

Deixa disso camarada

Me dá um cigarro.

ANDRADE, O. Obras completas. Volumes 6-7.

Rio de Janeiro: Civilização Brasileira, 1972.

\section{Introdução}

O poema Pronominais, publicado parcialmente nas páginas do jornal Correio da Manhã em 1924, e lançado, no ano seguinte, em Paris, no livro "Pau-Brasil", aborda uma questão amplamente discutida na pauta da intelectualidade brasileira nas primeiras décadas do século $\mathrm{XX}$, a emancipação cultural e linguística em relação aos padrões europeus. Em seu projeto artístico de incorporar a formação discursiva modernista, o poeta paulista evidencia o binômio ênclise $X$ próclise como representativa na definição contrastiva da identidade brasileira. Ao materializar - nos actantes sociais - as figuras do professor, do aluno e do mulato sabido, simboliza a rede de relações articuladas e tangidas pelo conhecimento difundido pela escola na construção daquilo que figurava 
como o imaginário de um país e de uma população civilizada: a variação na colocação pronominal e a enorme lacuna social que a escolha das variantes linguísticas assinala.

É nesse espírito de época que mergulhamos para analisar um dos pilares constitutivos da cultura ocidental: a escola. Ela é compreendida como uma instituição difusora do conhecimento linguístico, de valores e saberes compartilhados e transmitidos socialmente. Essa concepção, definida por Bourdieu (1992) como capital cultural ${ }^{72}$, concebe a escola como um lugar de transmissão de conhecimento, considerando não só os agentes da educação, mas toda a rede de relações que se estabelece no ambiente escolar e que confere, a partir de estruturas simbólicas, a legitimação de um grupo sobre outros. Como discutimos nos capítulos anteriores, os jesuítas tinham clareza desse papel social e a convicção da educação como alicerce da construção de uma sociedade fundamentada na filosofia cristã. No documento mais importante da educação jesuítica, o Ratio Studiorum, divisa-se que a educação nos colégios da Companhia visava à formação do homem perfeito e bom cristão ${ }^{73}$. As próprias Constituições, documento máximo dos soldados de Cristo, em sua parte $4^{\underline{a}}$, definia o papel dos colégios como 0 lugar para o progresso das virtudes pela construção do "edifício das letras e do modo de servir-se delas para melhor conhecer e servir a Deus Criador e Senhor nosso", lançando mão do expediente de "levar as almas ao fim para o qual foram criadas"; com a especificação de que, para atingir o objetivo, eram necessários, além do exemplo da vida, a doutrina e o modo de propô-la.

A construção do "edifício das letras" compreendia, como discorrido no Capítulo 2, a formação linguística a partir do ensino da Gramática (nos níveis inferior, médio e alto); das Humanidades e, no grau mais elevado da formação, da Retórica. Nessas classes, os alunos encontravam as ferramentas adequadas para "melhor conhecer e servir a Deus Criador e Senhor nosso". A língua e o ensino de língua eram as ferramentas para o alcance de seu objetivo maior, a propagação da palavra de Deus.

\footnotetext{
$72 \mathrm{O}$ capital cultural é entendido como um recurso que as classes dominantes utilizam para acentuar as diferenças sociais. Nesse sentido, o termo 'cultura' refere-se aos valores que definem e orientam um grupo social como um instrumento de dominação.

${ }^{73}$ Leonel Franca, SJ (1952[1986]:12)
} 
O colégio jesuítico desenha-se como espaço institucional no qual se encontram evidenciados os sistemas de dominação e reprodução das relações sociais que define Bourdieu e que "permitem à cultura dominante numa dada formação social cumprir sua função político-ideológica de legitimar e sancionar um determinado regime de dominação" (MICELI, 2001, p.XVI), assumindo para si "o carisma grupal distintivo" que

opõe os grupos "estabelecidos" aos "outsiders" (ELIAS, 2000 [1965]). É essa reflexão que vai nos guiar na discussão do padrão gramatical utilizado na escola, tendo por mote a colocação pronominal cujas práticas denunciavam a afiliação à variedade portuguesa ou brasileira do português.

Neste capítulo, pretendemos recompor a cartografia linguística dos jesuítas e de suas redes sociais na virada do século XX, compreendendo o estilo da comunidade de prática $^{74}$ em questão e procurando articular as discussões linguísticas com os fatos históricos e sociais, conforme definem os estudos de Labov $(1972,1974,1982,1994)$ e Eckert (2000) para a sociolinguística.

\section{1. $\mathrm{O}$ "período pronominal" ${ }^{75} \mathrm{da}$ língua portuguesa}

As pesquisas dedicadas ao estudo do vernáculo, especificamente no estudo da modalidade falada da variedade brasileira, identificaram na passagem do século XIX para $\circ \mathrm{XX}$ peculiaridades linguísticas que diferenciavam substancialmente essa variedade da matriz portuguesa. Entre os fenômenos linguísticos listados estava a generalização da colocação pronominal proclítica (CYRINO, 1993; GALVES, 2001; KATO 2002; GALVES, TORRES MORAIS e RIBEIRO, 2005, entre outros). Em linhas gerais, os trabalhos apontam que a próclise generalizada está presente, nesse momento e posteriormente, na gramática do português falado em praticamente todo o território

\footnotetext{
${ }^{74}$ Ver nota 9.

75 Em artigo de 1919, Mário de Alencar alcunha a expressão "Período Pronominal”, referindo-se ao assunto que se encontrava no centro das polêmicas sobre as diferenças entre o Português europeu e o brasileiro. Em suas palavras, "é raro o dia em que (as prédicas públicas a serviço do fetiche gramatical) não apregoam a receita dos pronomes". (ALENCAR, M., 1981[1919], p. 458)
} 
brasileiro e, por isso mesmo, é um divisor das variedades portuguesa e brasileira, pois se toma por pressuposto que aquela é tendencialmente enclítica e esta proclítica ${ }^{76}$.

Como contraponto ao quadro do português vernacular, surgiram estudos sobre a constituição da modalidade escrita do português padrão culto brasileiro - e estes nos interessam mais especificamente, dada a composição do nosso corpus. Os trabalhos representativos dessa linha de pesquisa estão fundamentalmente voltados para a colocação pronominal77 (PAGOTTO, 1992, 1998; SCHEI, 2000; PAGOTTO e DUARTE, 2005; OLIVEIRA, 2011, 2013, 2014; SANTOS SILVA, 2012; TELLES, 2014).

Em uma série de estudos sobre o estabelecimento da norma culta no Brasil, Pagotto $^{78}$ discute a crise que se instalou entre os séculos XIX e XX decorrente da proposta da elite de construção de um país moderno e civilizado. Na visão do autor, a elite brasileira teria buscado se diferenciar e se distanciar da língua falada pelas classes mais baixas da sociedade por meio de uma "unificação linguística normativa" com Portugal. Na conjunção do padrão culto brasileiro com a variedade europeia da língua portuguesa, inúmeras novidades estariam presentes: as relativas cortadoras, as construções com quantificadores universais, a oposição entre onde e aonde e vários itens lexicais. Mas, a maior diferenciação estaria relacionada ao uso da ênclise que mostrava o abismo linguístico entre as classes sociais. Para o autor, as elites, colocando em ação o projeto de civilização do país, teriam selecionado o uso da ênclise tomando o modelo europeu em uma atitude de oposição ao vernáculo, que seria versão linguística da "barbárie".

Assumindo a hipótese de que, dentro do programa de civilização que promovia, a elite teria introjetado a norma gramatical portuguesa, repertório inacessível às classes mais baixas, para garantir a distância social entre as camadas econômicas, Pagotto e

\footnotetext{
${ }^{76}$ Consideramos ainda a análise de Paixão de Sousa (2004) e Galves, Britto \& Paixão de Sousa (2005) que a mudança na gramática do PB não seria fruto da mudança ocorrida na variante brasileira em relação à gramática do PE; mas que tanto o PE quanto o PB teriam como base o português clássico.

${ }^{77}$ Nessa mesma linha de pesquisa, saliente-se a tese de doutorado de Hélcius Pereira Batista (2010) sobre o sujeito pleno nas cartas das elites paulistanas do início do século XX, a dissertação de mestrado de Priscilla Barbosa Ribeiro sobre a ordem dos constituintes sentenciais em amostras produzidas pela Escola Normal de São Paulo (2011) e a dissertação de mestrado de Giovanna Ike Coan (2011) sobre as construções-se em anúncios publicitários do início do século XX.

${ }^{78}$ Pagotto: 1993, 1998, 2011.
} 
Duarte (2005) analisaram cartas do senador Ottoni e de sua esposa, e verificaram que o senador "opta por uma norma linguística mais lusitana e sua esposa deixa emergir mais fortemente as formas do português do Brasil" (p.80).

De outra perspectiva, Oliveira $(2011,2013,2014)$, ao atentar para o rótulo de brasileirismo atribuído pelos gramáticos portugueses ao uso da ênclise na modalidade escrita em contextos para os quais as regras normativas prescreviam o emprego da próclise (subordinadas e presença de negação, por exemplo), toma-se como pista de que a elite brasileira adotava essa colocação como modelo linguístico civilizado, entretanto, essa escolha ${ }^{79}$, na sua leitura, não reverberava o modelo português. Por esse viés, o português culto paulista assinalava, ao mesmo tempo, uma autonomia em relação ao português europeu e, também, garantia um sistema de distinção, de maneira a se afastar das classes menos escolarizadas da população.

Tendo esse pano de fundo, nossa escolha, assim, está vinculada às pesquisas no campo da linguística histórica que define a alternância entre próclise e ênclise como um dos grandes diferenciais no processo de constituição da variedade culta brasileira da língua portuguesa e à discussão da gramática de colocação pronominal como uma estratégia da elite intelectual (e também econômica) de distinção linguística. Temos, assim, como pressuposto a ideia de que a distribuição dos clíticos na sentença, ainda que balizada por uma norma, é orientada por escolhas pessoais (LOBO et alii, $1991 \mathrm{e}$ SCHEI, 2000), de modo que na colocação pronominal podemos enxergar marcas da língua que chamamos, em consonância com Santos Silva (2012) e Oliveira (2011), de "marcas sociais da diferença", evidenciando, no caso deste trabalho, as comunidades de práticas que se digladiam na arena política do interior paulista: os católicos e os republicanos.

Este capítulo é norteado pela seguinte questão: a qual padrão de escrita se vinculavam os jesuítas que se batiam por se manterem como "grupo estabelecido" (ELIAS, 2000[1965]:14). Afinal, os jesuítas ocupavam posições de prestígio e poder, na medida em que operavam pela "repetição de um discurso $0^{80 "}$ e se viam, pela tradição

\footnotetext{
79 Oliveira descarta a interpretação de hipercorreção, preferindo ler a ênclise na chave da marca social da diferença. ${ }^{80}$ NEVES (1978: 17) e VILAR (1999:50)
} 
instituída, como instrumentos divinos na transmissão - oral ou escrita - da Palavra Divina, expressa pelas Escrituras. Na perspectiva de dar continuidade à "missão civilizadora de Anchieta", o embate travado entre os jesuítas, que procuravam manter-se como condutores da educação do interior paulista, e os republicanos, que levantavam a bandeira na laicização do ensino, haveria a possibilidade de alinhamento linguístico entre os dois grupos?

Vale lembrar, como descrito na Parte 2 da Introdução, que o corpus foi formado por discursos de religiosos; discursos de Intelectuais Católicos ${ }^{81}$; textos escritos por jesuítas em sua revista Mensageiro do Coração de Jesus e no jornal Federação; e, ainda, textos do jornal laico $A$ República. Em sua composição, considerou-se a existência de diferentes comunidades de práticas: os Eclesiásticos e os Intelectuais Católicos se alinham como conservadores na tentativa de manutenção do status quo; e, os Republicanos que se contrapõem ideologicamente ao grupo, formam outra ${ }^{82}$. Ao pensar na materialidades dos textos produzidos pelos grupos, em consonância com as condições específicas em que são produzidos e recebidos, isto é, no diálogo (BAKHTIN, 2003) entre as diferentes comunidades de práticas, buscamos pistas de marcas identitárias dos grupos, tomando por baliza a colocação pronominal por ter sido tema linguístico candente no período em exame, a ponto de Mário Alencar denominá-lo "Período Pronominal".

\footnotetext{
81 É importante salientar que no grupo dos "Intelectuais Católicos" encontram-se personalidades da época que, escolhidas pelo colégio para discursarem, versavam sobre a importância da instituição, as expectativas para o futuro e a retidão de caráter de um cristão. Os autores são figuras relacionadas ao colégio, ou por terem sido alunos, ou por ocuparem posições de destaque na política, cargos de alto escalão na administração pública, vindos a dar o bom exemplo aos alunos do colégio, honrando a tradição e a formação católica. Dessa forma, consideramos coerente considerá-los como uma "comunidade de prática" pelas relações sociais de trocas simbólicas, assim como define Bourdieu.

${ }^{82}$ Muito embora estejamos fazendo oposição entre duas comunidades de prática, aqui nomeadas de "grupo dos republicanos" e "grupo católico", não estamos nos referindo às suas crenças religiosas. Aqui são opostos como dois grupos sociais que, por suas ações e práticas, alinham-se dentro de um espaço social estruturado dentro de princípios ideológicos organizadores de práticas sociais e representações.
} 


\subsection{A colocação pronominal do interior paulista: $O$ modelo jesuítico confrontado}

\subsubsection{A moldura pronominal: orações finitas}

A história do português é marcada por oscilações sucessivas em relação à posição do clítico $^{83}$ (LOBO, 1992; MARTINS, 1994; GALVES, BRITO, PAIXÃO DE SOUSA, 2006): entre os séculos XIII e XVI, o movimento é de diminuição da ênclise em favor da próclise quase absoluta nas sentenças finitas. A partir do século XVIII é a ênclise que passa a ganhar proeminência nas sentenças ${ }^{84}$ finitas (nas orações independentes, matriz e primeiras coordenadas ${ }^{85}$ ), independentemente de 0 verbo aparecer encabeçando ou não a sentença $\left(\mathrm{V} 1^{86}\right)$.

A existência de contextos não permeáveis a oscilações levou Galves e Lobo (2009) a definirem duas classes de colocação pronominal. Na primeira classe, estão os contextos que não sofrem nem variação nem mudança ao longo do tempo e se caracterizam pelo uso categórico da próclise: a) orações negativas; b) orações subordinadas; c) presença de quantificador; d) operador qu; e) sintagma focalizado; f) advérbios aspectuais, como se observam nos exemplos abaixo ${ }^{87}$.
a1) O Paulo não me fala.
a2) *O Paulo não fala-me.
b1) Todo mundo sabe que a viste.
b2) *Todo mundo sabe que viste-a.
c1) Alguém me chamou.
c2) *Alguém chamou-me.

\footnotetext{
${ }^{83}$ Reconhecemos a ampla discussão, principalmente dentro da teoria gerativa, que trata da distinção entre pronomes fortes, pronomes fracos e clíticos. No entanto, essa nomenclatura não assinala nenhuma diferenciação que possa afetar as discussões aqui estabelecidas. Assim, tomamos genericamente a palavra "clítico" como sinônimo de "pronome átono". Para informações sobre o assunto, verificar: CARDINALETTI, A. \& M. STARKE. 1999. The typology of structural deficiency: On the three grammatical classes. In: Henk van Riemsdijk. ed.. Clitics in the Languages of Europe, Empirical Approaches to Language Typology. Berlin: Mouton de Gruyter, 145-233 ou KATO, Mary. Pronomes fortes e fracos na gramática do português brasileiro. Revista Portuguesa de Filologia, Coimbra, v.20, p.101-122, 2002.

${ }^{84}$ Adotamos os termos "sentença" e "oração" indiferentemente para designar a construção sintática nucleada de verbo.

${ }^{85}$ Chamamos 1ạ. Coordenada a que a gramática designa de coordenada assindética; 2a. Coordenada corresponde à sindética.

${ }^{86}$ V1 diz respeito ao verbo em primeira posição absoluta da sentença (ex. Desejou-me paz).

${ }^{87}$ Os exemplos indicados com asterisco correspondem às formas agramaticais, isto é, não seriam formas possíveis para o falante da língua.
} 
d1) Quem me chamou?

e1) Só ele a entende.

f1) Eu sempre a encontrei no mercado. d2) *Quem chamou-me?

e2) *Só ele entende-a.

f2) *Eu sempre encontrei-a no mercado.

Nesta mesma classe, é prevista a ênclise para a posição inicial absoluta (V1):

g1) Achou-os ditosamente.

g2) *Os achou ditosamente.

A segunda classe, por sua vez, é permeável à variação e, portanto, à mudança que define os momentos de oscilação da colocação pronominal na história do português, levando-se em conta a presença de: h) sujeito referencial não focalizado; i) advérbios ${ }^{88}$; j) sintagma preposicional com função adverbial; k) conjunção coordenativa. Outro fator condicionante da colocação pronominal é a posição da oração no período, de modo que a oração matriz posposta a uma adverbial foi indicada como um dos vetores de análise $\left({ }^{2}\right)^{89}$. Nestes dois últimos contextos, encontra-se um percentual de ênclise mais elevado do que aquele observado para os demais contextos, variando também em relação ao autor:

h1) As outras prophecias cumprem-se a seu tempo (A.Vieira, n. 1607)

h2) Estes thesouros... se abrirão a seu tempo (A.Vieira, n.1607)

i1) Agora queero-Ihe dizer algumas cousas... (A.Costa, n. 1714)

i2) Hoje me parto (A. Chagas, n. 1631)

j1) Em troca disto, ofereço-Ihe da parte de Inglaterra defesa de tôdas as suas colónias ... (Alorna, n.1750)

j2) Com este aviso Ihe foi juntamente infundida notícia dos excessos que entre estas duas súbditas suas passavam (Bernardes, n.1644)

\footnotetext{
${ }^{88}$ Observe-se que não houve a distinção de contextos de verbos simples e de grupos verbais.

89 Os contextos descritos em (I1), (I2) são rotulados pelas autoras como sendo de orações dependentes. Preferimos restringir o termo "orações dependentes" àquelas introduzidas por conjunções coordenativas.
} 
k1) Achou-os ditosamente, falou-lhes, e rendeu-os a largarem aquela vida brutal (A.Barros, n.1675)

k2) Durando as persuasões do padre, chegou preparada uma mezinha, e lhe pediram se retirasse. (Bernardes, n.1644)

I1) Para os começar a render, animou-os com donativos, língua a todas as Nações não menos inteligíveis, que grata. (A.Barros, n.1675)

I2) Vendo-o um Cónego no adro daquela antiga Sé Ihe disse: De quem sois meu menino? (A.Barros, n.1675).

Os resultados desse mapeamento diacrônico mostram duas fases do português. Até 1700, tem-se uma gramática na qual a próclise é uma opção não marcada, ainda que não exclua a ênclise, que ocorre em taxa percentual de 20\%; no período subsequente evidencia-se a mudança gramatical que torna a ênclise a única opção (GALVES, BRITO, PAIXÃO DE SOUSA, 2006). A curva do gráfico mostra a mudança em dois tempos nas orações não-dependentes (matriz, independente, primeira coordenada, justaposta): da ênclise para a próclise, com inflexão na $2^{a}$. metade do XV, e da próclise para a ênclise, duzentos anos depois.

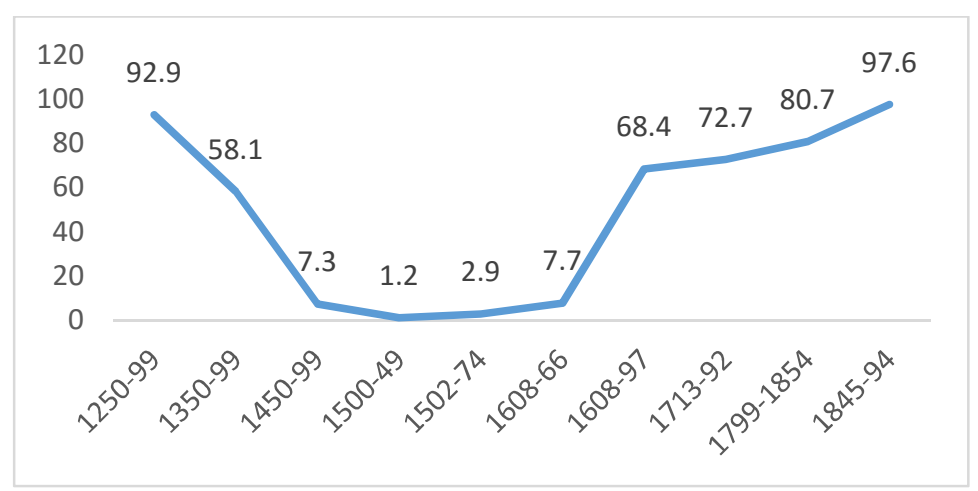

Gráfico 1: Diacronia da ênclise nas orações não-dependentes (Adaptado de Martins, 1997)

Os resultados da colocação pronominal em textos literários brasileiros dão continuidade à curva ascendente da ênclise, ainda que com percentuais mais baixos: 
nas 2 $2^{\mathrm{a}}$. coordenadas, a ênclise girou entre $70 \%$ e $90 \%$ nos textos dos autores românticos e $99 \%$ dos realistas; nas orações independentes e matrizes com sujeito expresso a ênclise ficou nas narrativas em torno dos $60 \%$, entre os românticos, e $90 \%$, entre os realistas. Nos diálogos, porém, a ênclise não ultrapassa os 30\%. (SCHEI, 2010)

Em direção oposta ao português moderno, o português brasileiro enveredou para a generalização da próclise, inclusive em posição inicial da sentença, a ordem V1, contexto que normalmente é visto como impermeável à variação. Entretanto, no século XIX, a ocorrência de próclise com V1 é extremamente baixa nos textos literários (9/1290), o que corresponde a apenas $0,7 \%$ (SCHEI, 2010). Poucos são os trabalhos que explicam a implementação da próclise pelo viés da história social, devido ao apagamento do clítico no português popular, que se processou concomitantemente ao crescimento da próclise. Entretanto, uma das motivações sociais para a generalização da próclise no PB está, segundo Oliveira (2015), no perfil dos imigrantes portugueses (baixa escolaridade e proveniência de regiões de antiga colonização, como os Açores) ${ }^{90}$ que, por hipótese, teriam uma gramática conservadora, com traços do português quinhentista $e$ seiscentista.

Contrariamente à próclise vernacular que caracteriza o PB, o estudo diacrônico da colocação pronominal em sentenças finitas com verbos simples (coordenadas ou não) em correspondências oficiais escritas no Brasil, refletindo um modelo de língua escrita, mostrou o contrário: a próclise que oscilava entre 80 e 90\% desde a 1․a. metade do século $\mathrm{XVI}$ até a 1‥ metade do XIX teve uma queda brusca a partir da $2^{2}$. metade do XIX, atingindo a marca de 55\% (PAGOTTO, 1993). Já as cartas pessoais do senador Ottoni e de sua mulher escritas no século XIX apresentam diferenças de gênero, associadas, naturalmente, ao grau de escolarização: o senador adota a ênclise e sua mulher a próclise.

No que concerne às orações dependentes, outro contexto normalmente tido como impermeável à variação, o PB, como assinalaram as gramáticas da virada do século XX,

\footnotetext{
${ }^{90}$ Acrescente-se o uso da próclise em sentenças finitas por imigrantes de dialetos italianos e espanhol.
} 
exibia o uso da ênclise em lugar da regra categórica da próclise, ainda que em índices percentuais baixíssimos. Com efeito, Lobo (2001) encontrou 5,1\% nas cartas do Recôncavo Baiano; média semelhante foi encontrada nos romances de escritores brasileiros oitocentistas, salvo em Alencar em que o índice de ênclise atingiu 14\% (SCHEI, 2010). A análise da escrita de intelectuais paulistas (XIX-XX) tornou evidente a presença, ainda que baixa, da colocação enclítica (52/ 472 dados, ou seja, 10,5\%) (SANTOS SILVA, 2012), como pode se observar no gráfico abaixo:

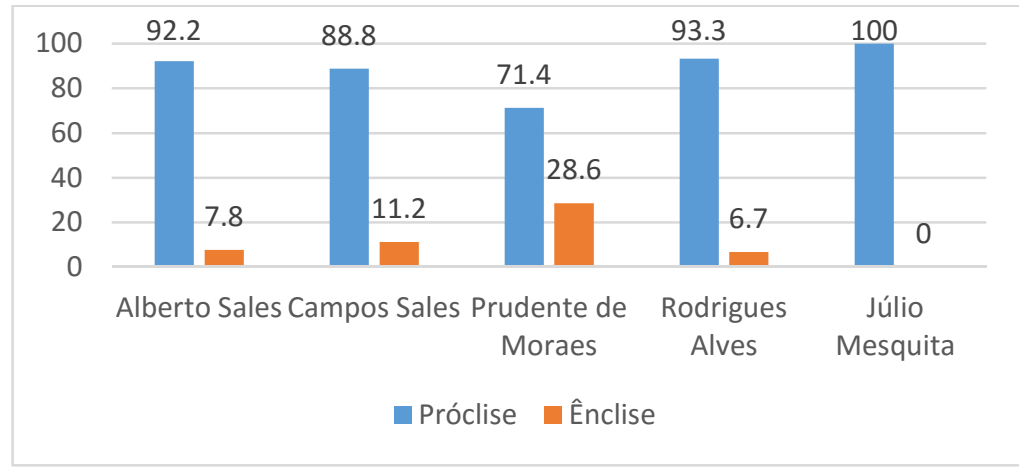

Gráfico 2 - Próclise/Ênclise em orações dependentes por falante (Adaptado de Santos Silva, 2012)

Os intelectuais apresentam, para as orações dependentes, uma colocação pronominal proclítica, dados que corroboram, segundo a autora, os achados de Carneiro (2005), Martins (2008) e Oliveira (2011), que obtiveram resultados percentuais inferiores a $17 \%$ para os dados do século XIX. Os resultados também coadunam o levantamento feito por Lopes (2010) para os dados do corpus Histórico Tycho Brahe, que atesta uma presença discreta de ênclise do século XVI ao XIX nos diversos tipos de orações dependentes.

Considerando o comportamento pendular da colocação pronominal no português, passamos a analisar a sua distribuição no material representativo das comunidades de práticas: Imprensa republicana versus jesuítica e discursos de Intelectuais Católicos versus Eclesiásticos. Diferentemente dos trabalhos que trataram com a oposição orações dependentes e independentes, optamos por desmembrar o grupo de orações arroladas no bloco das independentes, separando, portanto, as orações independentes 
(e matrizes), as $2^{\text {a }}$ coordenadas, e as justapostas, para observar se todas elas se comportam da mesma maneira ou se se alinham às orações dependentes.

\subsubsection{Comunidades de prática em evidência}

\subsubsection{A pintura pronominal nas comunidades de prática}

Conforme explicado na metodologia, o corpus para a análise linguística é dividido em duas partes: na primeira, estão os textos referentes à produção do grupo católico:

a. publicações da Imprensa Católica de Itu, correspondentes à Revista Mensageiro do Coração de Jesus e ao jornal Federação;

b. Discursos de oradores católicos (os quais chamamos de Intelectuais Católicos), que discursaram por ocasião de festividades do Colégio para a colação de grau dos bachareis em letras do ginásio do CSL;

c. Discursos de Eclesiásticos que discursaram para as festas colegiais em homenagem a São Luiz de Gonzaga.

A segunda parte contempla os textos publicados no jornal República, pois este representa o grupo de oposição ao grupo católico em atuação na mesma cidade. Os dados foram computados em separado para que possamos observar padrões do comportamento linguístico em relação às comunidades de prática definidas.

Para a análise da colocação pronominal em sentenças finitas, escolhemos como fatores linguísticos condicionadores o tipo de oração (independente, justaposta, subordinada ou $2^{\mathrm{a}}$ coordenada) e a natureza do elemento que ocupa a primeira posição na sentença antecedendo o verbo (sujeito, sintagma adverbial ${ }^{91}$, estrutura de foco ou quantificador). Dessa forma, procedemos a uma análise geral dos dados e, em seguida, partimos para uma análise detalhada por comunidades de práticas, considerando os

\footnotetext{
${ }^{91}$ Na categoria "sintagma adverbial" agrupamos advérbios, locuções adverbiais e orações adverbiais.
} 
Católicos e os Republicanos como grupos distintos. Assim, temos dois subgrupos de comunidades de práticas cujas produções serão analisadas, a partir do objeto linguístico da colocação pronominal para observar se os seus usos são semelhantes ou se marcam distinções: Imprensa Católica e Imprensa Republicana; Discursos de Eclesiásticos e Discursos de Intelectuais Católicos.

Tomando a tipificação dos grupos variáveis e invariáveis da colocação pronominal como medida (GALVES \& LOBO, 2009), excluímos da computação os contextos que não sofrem variação, ressalvando-se que as orações subordinadas, por apresentarem variação no nosso corpus, foram mantidas na análise. Por aparecerem no corpus em posição enclítica e proclítica de forma categórica, foram desconsiderados os clíticos em posição inicial da sentença, a ordem $\mathrm{V} 1$ (1-2) e os que se seguiam à negação (3-4), respectivamente ${ }^{92}$ :

(1) Chama-vos a postos o clarim vibrante das sentinellas. [ARANTES]

(2) Protegem-vos armas que, como as do guerreiro da lliada, foram forjadas por divino artifice. Com ellas sereis invenciveis. [LAET]

(3) O mais eminente dos philosophos modernos, Herbert Spencer, que não se amesquinhava nas estreitezas de um sectarismo intransigente, [PORCHAT]

(4) Sim, Irmãos e Filhos dilectissimos, não nos esqueçamos jamais de que somos todos membros de um só corpo, do corpo mystico de Jesus Christo - a Egreja, (...) [MCJ5]

O cômputo geral do material que analisamos apresenta baixa incidência de ênclise nos textos da primeira década do século XX: 213/830, perfazendo o total de $26 \%$.

\footnotetext{
${ }^{92}$ Apresentamos aqui os dados de próclise e ênclise obtidos nas sentenças negativas e em início absoluto de sentença, por autor. Trata-se de uso categórico:

\begin{tabular}{|c|c|c|}
\hline & Negativas (Próclise) & V1 (Ênclise) \\
\hline Intelectuais Católicos & 37 & 30 \\
\hline Eclesiásticos & 10 & 10 \\
\hline Jornal Republicano & 8 & 5 \\
\hline Imprensa Jesuítica & 16 & 25 \\
\hline
\end{tabular}
}


Esses dados corroboram diversos outros estudos que mostraram que a próclise era uma opção generalizada na gramática do português brasileiro, cf. Lobo (1992), Abaurre e Galves (1996), Galves (2001), entre outros.

Foram elencados os contextos de orações subordinadas, coordenadas (introduzidas por conjunções coordenativas, às quais nomeamos $2^{\text {a }}$ Coordenada), orações independentes e justapostas:

\section{Subordinada}

(5) Como prova desses conhecimentos é que o Governo Federal vos confere essa carta de sciencias e de letras que levaes para servir de ingresso nos estabelecimentos de ensino superior. [PRESTES]

(6) porque as suas portas estavam fechadas, quando ouviu-se uma voz sobrenatural, a voz de Maria, a sahir miraculosamente de sua imagem prodigiosa, e que d'este modo exprobrava ao guardo do sanctuario (...) [BRASILIO MACHADO]

\section{$2^{\text {a }}$ Coordenada}

(7) (...) reveste o arnez da charidade, e assim armado não só resiste aos amiudados assaltos da hoste infernal, mas a investe elle o primeiro, (...) [PE.FIALHO]

(8) Luiz obedecia a seus professores, estimava seus collegas, e sujeitava-se jubilosamente aos sacrificios inherente á vida collegial. [ARC. FONTOURA]

\section{Independente}

(9) O reverendo Reitor nos disse que o collegio não tem nada com o caso (...) [REP30/1908-812]

(10) Metade dos seus levara-Ihe esta terrivel enfermidade das bexigas [MCJ2] 


\section{Justaposta}

(11) As irmans de caridade ainda continuam sua caridosa assistencia nos hospitaes, as do Bom Pastor multiplicam seus asylos, as de S.José e S. Dorothéa se esmeram (...) [MCJ2]

(12) Corajoso e decidido o menino desce as escadarias do seu palacio, dirige-se á Egreja da Annunciata [MS.MACEDO COSTA]

Ainda em termos gerais, a Tabela 1, abaixo, sistematiza os resultados considerando o tipo de oração no qual se encontra a ocorrência.

\begin{tabular}{|l|r|r|}
\hline Subordinada & $18 / 448$ & $4 \%$ \\
\hline $2^{\text {a }}$ Coordenada & $32 / 116$ & $28 \%$ \\
\hline Independente & $115 / 210$ & $55 \%$ \\
\hline Justaposta & $48 / 56$ & $86 \%$ \\
\hline
\end{tabular}

Tabela 1: Distribuição de ênclise por tipo de oração

Como esperado, há um baixo índice de ênclise nas orações subordinadas (dependentes), com apenas $4 \%$ das ocorrências. As subordinadas e as segundas coordenadas se comportam de maneira semelhante, por acionarem o uso da próclise, ainda que em percentuais bastante diferentes (96\% e $72 \%$, respectivamente). Já as orações independentes e as justapostas se aproximam por serem contextos favorecedores da ênclise.

Nas subordinadas, a próclise ocorre em percentual quase absoluto; seja o antecedente uma relativa (13), uma completiva (14) ou uma adjunta/circustancial (15):

(13) "Ella consiste em um apparelho electrico, que se applica aos trens, e dá ao machinista modo de avisar na distancia de um kilometro" [MCJ2]

(14) "Depois convêm que se reunam congressos regionaes e particulares" [MCJ8] 
(15) "As materias a tratar no Congresso devem ser sufficientemente preparadas, para que se evitem discussões" [MCJ3]

O emprego da próclise nas subordinadas é respeitado em contexto da presença de orações intercaladas (16) e na justaposição de subordinadas (17):

(16) "Si queremos que nosso Congresso produza fructos serios e duraveis, é preciso que, evitando toda semelhança com as assembléas parlamentares, se tornem, quanto á forma, o que são em realidade" [MCJ3]

(17) "o menino dizia comsigo que 1 a sociedade $o$ livrára das faixas da infancia, $\varnothing_{1} O$ emancipára de sua tutela religiosa o que bem depressa significava para elle" [MCJ12]

Ao contrário do que se verifica para as subordinadas, na $2^{2}$ coordenada a intercalação de elementos é um condicionador da colocação enclítica, como se elementos intervenientes favorecessem uma leitura de justaposição de orações:

(18) Mas, basta, Senhores, que se confrange o coração e, rebeldes, sóbem-me as lagrimas aos olhos... [ARANTES]

(19) Viestes ter a esta casa, a Colchida do saber e da virtude, e as lagrimas dos vossos, originadas do egoismo do amôr, enxugaram-se pela certeza de que nella vinheis encontrar o carinho e o conforto necessarios, [CAMARA LEAL]

A grande oscilação na colocação pronominal nas orações independentes levounos à análise do elemento que precede o verbo para averiguar o seu peso na distribuição do clítico. Assim, para a próxima tabela, escolhemos nos deter nessas orações e verificar aí o contexto que antecede o clítico.

\begin{tabular}{|l|r|r|}
\hline Sujeito não-focado & $50 / 94$ & $55 \%$ \\
\hline Sintagma Adverbial & $63 / 100$ & $63 \%$ \\
\hline Foco & $1 / 7$ & $14 \%$ \\
\hline Quantificador & $1 / 9$ & $11 \%$ \\
\hline
\end{tabular}


Tabela 2: Ênclise por tipo de elemento na 1a posição sentencial

Era de se esperar que quantificadores e elementos focalizadores acionassem categoricamente a próclise, pois esses são contextos propícios a essa marcação, entretanto, embora em números mínimos, encontramos usos de ênclise:

(20) Dahi essa longa série de qualificativos, cada qual mais eloquente, a ennobrecer a sua dignidade:- uns, chamam-n'os, as partes nobilissimas do corpo de Pedro; (...) [BRASILIO MACHADO]

(21) Tudo é admiravel, a natureza mesmo parecia-me mais encantadora (...) [MCJ6]

Quanto à presença de sujeito lexical ou pronominal e de sintagmas adverbiais, a ênclise é ligeiramente mais presente nos dados (55\% e 63\%, respectivamente):

(22) Deus chamou-vos, Eminentissimo Senhor, para destinos admiraveis, vas mirabile, [BRASILIO MACHADO]

(23) «Hontem - pontifica assim a sabedoria contemporanea, pela boccca de Clemenceau - hontem acreditava-se; hoje pensa-se.(...) [ARANTES]

Como discorremos acima, a análise da distribuição do clítico em diversos contextos salientou o comportamento das segundas coordenadas muito próximo ao das subordinadas, o que pode indiciar que a conjunção, seja ela subordinativa ou coordenativa, é fator determinante para a escolha da ênclise. No caso das independentes, seu comportamento está mais próximo àquele verificado nas justapostas, o que sugere que o contexto entoacional ${ }^{93}$ é fator atuante. Ainda a partir das independentes, a presença de sintagma adverbial e de sujeito não-focado foram os fatores que propiciaram a escolha da ênclise.

\footnotetext{
${ }^{93}$ Galves (2003) verificou uma alta frequência da ênclise nos sermões de Pe. Vieira todas as vezes em que havia um tópico contrastivo [Ex. Elles conheciam-se, como homens, Christo conhecia-os, como Deus. (VIEIRA, 1608, Corpus Tycho Brahe)], o que constituiria uma evidência do peso da prosódia na colocação pronominal. Acrescentamos a essa leitura a repetição de estrutura.
} 
Nessa primeira parte, foram computados os dados que trouxeram a configuração geral da colocação pronominal na primeira década do século XX em Itu. A seguir, procuramos distinguir a distribuição entre as comunidades de práticas. Destacamos, primeiramente, a colocação pronominal dos republicanos e, então, comparamos os resultados com os dados do grupo católico.

\subsubsection{Textos jornalísticos e discursos: tonalidades pronominais}

Para observar se a distribuição de próclise e ênclise no grupo dos eclesiásticos do interior paulista acompanha o padrão dos republicanos ituanos, nesta seção procedemos a uma comparação da sintaxe dos jornais e revistas em circulação na cidade de Itu (o jornal República, liderado pelos Intelectuais Republicanos; e a Revista Mensageiro do Coração de Jesus e o Jornal Federação, mantidos pelos jesuítas) e dos discursos de Intelectuais Católicos ${ }^{94}$ e eclesiásticos, cujos dados gerais são expressos na tabela abaixo:

\begin{tabular}{|cc|cc|cc|cc|}
\hline Jornal Republicano & \multicolumn{2}{|c|}{ Imprensa Jesuítica } & \multicolumn{2}{|c|}{$\begin{array}{l}\text { Intelectuais } \\
\text { Católicos }\end{array}$} & \multicolumn{2}{|c|}{ Eclesiásticos } \\
\hline $33 / 67$ & $48 \%$ & $80 / 260$ & $31 \%$ & $72 / 359$ & $14,5 \%$ & $28 / 114$ & $19,5 \%$ \\
\hline
\end{tabular}

Tabela 3: Distribuição de ênclise: comunidades de prática

A tabela acima traz os resultados de dois tipos de gêneros de discursos, marcando, de um lado, a diferença no uso da colocação pronominal entre jornais republicano e jesuítico e, de outro, a diferença de colocação pronominal entre os discursos dos Intelectuais Católicos e Eclesiásticos. No cômputo geral, o Jornal Republicano exibe uma gramática bem mais enclítica do que a da Imprensa Jesuítica. Ambos, porém, se distanciam dos textos discursivos que apresentam índices baixos de ênclise, em um

\footnotetext{
${ }^{94}$ Com alguma variação de estilo, os Intelectuais Católicos apresentam índices baixos na escolha da ênclise, oscilando de $11 \%$ a 37\%. O percentual de cada orador é: R. Porchat (15\%), C. Laet (11\%), J.Mendes (14\%), C.Leal (25\%), J. Prestes (16\%) e B. Machado (19\%).
} 
alinhamento com o uso da ênclise em um terceiro gênero do discurso: as Cartas Brasileiras contabilizam 17\% (CARNEIRO, 2005) e as Cartas de Intelectuais Paulistas não exibem mais do que $10,5 \%$ de ênclise no contexto das orações finitas (SANTOS SILVA, 2012).

Esses resultados mostram que, não obstante o gênero discurso se caracterize pela erudição e ostentação verbal - e a ênclise dê um tom civilizatório à linguagem (PAGOTTO, 1998; OLIVEIRA, 2012), os discursos não exploram essa colocação pronominal, pelo menos no que diz respeito ao contexto das orações finitas.

Quando se avalia o tipo de oração, observa-se que a ênclise predomina numericamente e distributivamente, pois ocorre em diferentes tipos de orações, salvo nas subordinadas, contexto em que se mantém com índice baixo (16\%). Já na Imprensa Jesuítica, a ênclise se restringe às orações independentes e justapostas. Por sua vez, nos discursos a ênclise tipifica a oração justaposta, motivada, provavelmente, pela exposição oral em que a pausa prosódica instaura ambiente de oração independente, com verbo em primeira posição, acionando a ênclise:

\begin{tabular}{|l|rr|rr|rr|rr|}
\hline & \multicolumn{2}{|c|}{$\begin{array}{c}\text { Jornal } \\
\text { Republicano }\end{array}$} & \multicolumn{2}{|c|}{$\begin{array}{c}\text { Imprensa } \\
\text { Jesuítica }\end{array}$} & \multicolumn{2}{|c|}{$\begin{array}{c}\text { Intelectuais } \\
\text { Católicos }\end{array}$} & \multicolumn{2}{c|}{ Eclesiásticos } \\
\hline Subordinada & $5 / 31$ & $16 \%$ & $5 / 132$ & $4 \%$ & $8 / 226$ & $3,5 \%$ & $0 / 59$ & $0 \%$ \\
\hline $2^{\text {a }}$ Coordenada & $5 / 8$ & $63 \%$ & $10 / 28$ & $36 \%$ & $10 / 50$ & $20 \%$ & $7 / 30$ & $23 \%$ \\
\hline Independente & $20 / 25$ & $80 \%$ & $47 / 74$ & $64 \%$ & $30 / 59$ & $51 \%$ & $18 / 52$ & $35 \%$ \\
\hline Justaposta & $3 / 3$ & $100 \%$ & $18 / 26$ & $69 \%$ & $24 / 24$ & $100 \%$ & $3 / 3$ & $100 \%$ \\
\hline
\end{tabular}

Tabela 4: Ênclise por tipo de oração: comunidades de prática

Os Eclesiásticos apresentam uma sintaxe praticamente idêntica à do grupo dos Intelectuais. Entretanto, em relação às orações subordinadas especificamente, há uma pequena marcação de ênclise pelo grupo dos Intelectuais, mesmo não sendo um contexto previsto para essa marcação. No mesmo grupo ainda, efetiva-se uma colocação enclítica maior no caso das orações Independentes, com o percentual de $51 \%$, contra $35 \%$ dos Eclesiásticos. Esses resultados, porém, são bem diferentes daqueles 
encontrados por Martins (1997) ${ }^{95}$ nos textos de Vieira $(68,4 \%)$, os quais, por sua vez, se aproximam daqueles identificados na Imprensa jesuítica.

Restringindo a análise às independentes, na Tabela 5, a seguir, vemos que no Jornal Republicano o sintagma adverbial preposicionado ativa a ênclise de forma categórica e a presença do sujeito também constrange a ênclise, modelo seguido pela Imprensa Jesuítica, ainda que com valores sensivelmente mais baixos. Já os discursos apresentam maior variação nesse contexto, tendendo à próclise, principalmente entre os eclesiásticos:

\begin{tabular}{|l|cc|cr|cc|cc|}
\hline & \multicolumn{2}{|c|}{$\begin{array}{c}\text { Jornal } \\
\text { Republicano }\end{array}$} & \multicolumn{2}{|l|}{ Imprensa Jesuítica } & \multicolumn{2}{c|}{$\begin{array}{l}\text { Intelectuais } \\
\text { católicos }\end{array}$} & \multicolumn{2}{|c|}{ Eclesiásticos } \\
\hline Sujeito & $9 / 12$ & $75 \%$ & $19 / 28$ & $68 \%$ & $11 / 22$ & $50 \%$ & $11 / 32$ & $34 \%$ \\
\hline S. Adverbial & $11 / 11$ & $100 \%$ & $27 / 42$ & $64 \%$ & $15 / 29$ & $52 \%$ & $7 / 15$ & $47 \%$ \\
\hline Foco & $0 / 0$ & $0 \%$ & $1 / 2$ & $50 \%$ & $0 / 4$ & $0 \%$ & $0 / 1$ & $0 \%$ \\
\hline Quantificador & $0 / 2$ & $0 \%$ & $0 / 2$ & $0 \%$ & $1 / 1$ & $100 \%$ & $0 / 4$ & $0 \%$ \\
\hline
\end{tabular}

Tabela 5: Ênclise por tipo de elemento na $1^{\underline{a}}$ posição sentencial: comunidades de prática

A gramática republicana é bem mais enclítica do que a jesuítica. Naquela, a presença de sujeito não-focado ou sintagma adverbial praticamente inibe a próclise, já na gramática jesuítica, essas mesmas funções favorecem a variação na distribuição dos clíticos.

Dois são os fatores que particularizam a gramática jesuítica frente à gramática republicana; o primeiro é a presença de conjunções subordinativas ou coordenativas que ativam a próclise, sendo que, na gramática republicana, apenas a conjunção subordinativa ativa a próclise; o segundo diferencial são os sintagmas não-quantificados (i.e., sujeitos não-focados e sintagmas adverbiais) que criam um ambiente de variação, sendo que, na gramática republicana, são ambientes apenas de ênclise.

\footnotetext{
${ }^{95}$ Martins inclui no grupo de não-dependentes as orações matriz, independente, justaposta e segunda coordenada.
} 
A hipótese inicial era a de que os Intelectuais Católicos iriam apresentar uma sintaxe de colocação mais próxima daquela encontrada no Jornal Republicano, visto que esses indivíduos, em suas posições sociais, compartilharam cadeiras na política e tiveram sua educação, em sua maioria, na Academia de Direito do Largo São Francisco. No entanto, não é o que ocorre. A condição de produção do texto parece se sobrepor como fator condicionante da colocação pronominal, visto que o discurso foi elaborado para ser lido em ambiente jesuítico no qual o interlocutor visado e o objetivo a ser atingido são fatores primordiais. Assim, o contexto interlocutivo acionado por esses sujeitos na leitura dos discursos parece ser fortemente atuante.

\subsubsection{Orações finitas nas comunidades de prática: uma sintaxe comum?}

A discussão trazida no início deste capítulo sobre uma possível distinção da sintaxe dos jesuítas ituanos em relação à "sintaxe republicana paulista" 96 nos guiou a comparações sobre os usos linguísticos de cada uma das comunidades de práticas e mostrou que o grupo dos republicanos ituanos apresenta números mais altos de ênclise em todos os contextos finitos estudados. Os contextos mais favorecedores são os de $2^{\underline{a}}$ coordenada, independentes e justapostas, embora nem mesmo entre as subordinadas deixe de ocorrer a marcação.

O contexto de produção pareceu ser um fator diferenciador dos percentuais encontrados, uma vez que nos textos da Imprensa os números de ênclise mantiveramse mais altos do que nos discursos: nestes, é no grupo dos Eclesiásticos que se evidencia a sintaxe mais vernacular junto às finitas, isto é, com preferência proclítica. Esperava-se que o gênero discursivo trouxesse mais ênclise, dado que o preceito retórico do gênero é baseado na correção gramatical e na ostentação. Considerando que as orações justapostas, em que se prevê uma maior pausa entoacional no proferimento do discurso, são contexto de ênclise categórica, pode-se inferir que o tom civilizatório da ênclise está associado ao contexto normativo inibidor de próclise: a primeira posição na

\footnotetext{
${ }^{96}$ Expressão usada por Santos Silva (2012).
} 
sentença. Na presença de um sujeito ou elemento adverbial, a próclise segue os trilhos e as curvas vernaculares.

\subsubsection{0 quadro pronominal dos grupos verbais}

Cyrino(1993) e Pagotto(1993), ao estudarem peças de teatro e cartas, respectivamente, observaram a emergência no século XIX da colocação brasileira nos grupos verbais.

Dentro da proposta da gramática gerativa, o clítico pode se movimentar na sentença associando-se a diferentes tipos de verbo, em função do tipo de sentença. Considerando um grupo verbal constituído de dois verbos em que um deles é flexionado e o outro não, há quatro posições distintas para a cliticização ao verbo, a depender do seu alçamento (movimento do clítico da posição do segundo verbo, que não apresenta flexão, para a posição do primeiro verbo do grupo, que apresenta flexão):

\begin{tabular}{|c|c|}
\hline Com alçamento & Sem alçamento \\
\hline cl VV & V V-cl \\
te quero ver & Quero ver-te \\
\hline V-cl V & V cN \\
Quero-te ver & Quero te ver \\
\hline
\end{tabular}

Quadro 1: Posições do clítico X alçamento

Cyrino (1993) e Pagotto (1993) apontam que, na virada do século XIX-XX, o português brasileiro começa a apresentar preferência pela estrutura sem alçamento ( $\mathrm{V}$ $c N)$, posição que se torna regra geral, independentemente da presença de elementos atratores; já o português europeu adota as demais posições para o clítico, dependente que é da condição sintática.

Com efeito, nas amostras colhidas por Lobo (2001) para dados do Recôncavo Baiano, nas Cartas Baianas de Carneiro (2005), na Escrita Catarinense de Martins 
(2009) e, ainda, nos dados extraídos do Almanaque Literário (SANTOS SILVA, 2012), a estrutura $V c / V$, ainda que com baixos índices percentuais, é atestada no século XIX:

\begin{tabular}{|c|c|c|c|c|c|c|}
\hline & $\begin{array}{l}\text { LOBO } \\
(2001)\end{array}$ & \multicolumn{2}{|c|}{$\begin{array}{c}\text { CARNEIRO } \\
(2005)\end{array}$} & \multicolumn{2}{|c|}{$\begin{array}{c}\text { MARTINS } \\
\text { (2009) }\end{array}$} & $\begin{array}{c}\text { SANTOS } \\
\text { SILVA (2012) }\end{array}$ \\
\hline & XIX & $X I X-1$ & $X I X-2$ & $\mathrm{XIX}-1$ & XIX - 2 & XIX \\
\hline$c l \vee \vee$ & $52,7 \%$ & $43,7 \%$ & $44,6 \%$ & $47,6 \%$ & $25,7 \%$ & $45 \%$ \\
\hline $\mathrm{V}-\mathrm{c} / \mathrm{V}$ & $5,5 \%$ & $15,3 \%$ & $29,2 \%$ & $29,2 \%$ & $5,9 \%$ & $12 \%$ \\
\hline $\mathrm{VVCl}$ & $26 \%$ & $28,4 \%$ & $15,4 \%$ & $15,4 \%$ & $55,3 \%$ & $37 \%$ \\
\hline $\mathrm{V} c \mathrm{~N}$ & $8,9 \%$ & $12,6 \%$ & $10,8 \%$ & $10,8 \%$ & $13,1 \%$ & $6 \%$ \\
\hline
\end{tabular}

Tabela 6 - Distribuição de clíticos em grupos verbais ${ }^{97}$

(Adaptado de: Lobo 2001, Carneiro 2005, Martins 2009, Santos Silva 2012)

Na comparação dos resultados dos quatro estudos, evidencia-se a alta frequência de construções com alçamento do clítico ( $c$ VV), provavelmente movido pela presença de atratores (conjunção subordinativa, negação ou elementos focalizadores), e de construções sem alçamento do clítico (VVcl). Schei (2010) identificou $81 \%$ de $V$ Vcl nas narrativas e $34 \%$ nos diálogos, gênero em que começa a se manifestar a próclise ao segundo verbo (15\%), que veio marcar o português brasileiro.

Para os dados da escrita dos Intelectuais Paulistas, Santos Silva (2012) assinala a preferência pelo não-alçamento do clítico $(49,5 \%$ de VVcl contra 39\% de clVV, 3,5\% de V-cl V e $8 \%$ de V clV).

A análise da autora faz depreender um aspecto da variação em relação ao grupo dos Intelectuais Paulistas que preferem o padrão sem alçamento, o que difere do padrão europeu de colocação pronominal onde ocorre a subida do clítico e, também, das outras variedades atestadas em outras regiões do país.

Os trabalhos citados, entretanto, tratam do alçamento e do não-alçamento do clítico sem atentarem para o contexto oracional, ou seja, sem observam o peso de um elemento atrator. Mais do que comparar estruturas com e sem alçamento, é necessário

\footnotetext{
${ }^{97} \mathrm{~A}$ autora analisa separadamente os grupos verbais preposicionados $\left(\mathrm{V}_{1 \text { finito }}+\right.$ preposição $(\mathrm{de})+$ clítico $+\mathrm{v} 2$ infinitivo $)$
} 
comparar a colocação pronominal em cada bloco, para ver analisar o peso condicionante de elementos atratores ou o seu desregramento.

\subsubsection{Paralelas pronominais}

Em nosso corpus, a seleção considerou as quatro posições que o clítico pode tomar, conforme exemplificamos:

\section{Com alçamento}

\section{cIVV}

(24) E quando se procura encontrar, em intimo consorcio, a sciencia e a virtude, isto é, o amor da verdade e o amor do proximo, (...) [PORCHAT]

\section{V-cIV}

(25) Devem-se evitar essas atitudes. [MCJ]

\section{Sem alçamento}

\section{VcIV}

(26) Por isso em cada pagina de nossa historia, como em cada recanto do nosso territorio, quer se encontre n'elle um germem de progresso e de civilisação, (...) [PRESTES]

\section{VV-cl}

(27) (...) o escriptor do artigo correspondente com tres linhas de uma noticia que serve perfeitamente para revelar como certa imprensa procura desempenhar-se do compromisso de lealdade (...)[FED26/1908-189]

Na delimitação dos dados, preferimos descartar os itens com gerúndio e particípio, assim como as estruturas com mais de dois verbos, como exemplificado: 
(28) (...) que grandes romarias se estejam organizando (...) [MCJ]

(29) É preciso combatel-os desde já e isto deve começar negando-se-lhes o prestigio official á sombra do qual vão fazendo o que querem. [REP33/1908-817]

Também foram separadas as construções verbais com a construção haver de, que configuraram um total de 7 ocorrências no corpus. Esse verbo preposicionado ativa a posição $c / V V$ ou $V V c l$ :

(30) Si Deus ordenou ao corpo: tu és pó e em pó te has de tornar; (...) [ARANTES]

(31) (...) não foi recahir nem no saber nem no talento, mas, sem duvida, no coração, porque foi de uma longa convivencia, de que hei de recordar-me com deliciosa saudade, (...) [PRESTES]

Foram excluídos os clíticos com função de argumento do segundo verbo, pois a sua posição tende a ficar na órbita do verbo que o seleciona, o que impossibilita a análise de subida do clítico para posições mais altas na sentença. É o caso de verbos perceptivos e causativos, que por atributos semânticos e sintáticos, constituem diferentes níveis de integração sintática:

(32) Deixam-nas lêr (...) [MCJ]

Assim, encontram-se em nossa análise as construções verbais com verbos infinitivos, validados aqueles com verbos auxiliares modais (exs: dever, poder, saber) e temporais (ex: ir) $)^{98}$ :

(33) O duque de Mantua seu parente proximo, diversos Bispos e alguns sacerdotes mesmo da Companhia de Jesus, intentam demovel-o de sua inabalavel resolução. Para cumulo de infortunio, seu proprio pae retratou o consentimento dado (...) [ARC. FONTOURA]

\footnotetext{
${ }^{98}$ Embora alguns estudos (Ex. Santos Silva, 2012) proponham a subdivisão desses grupos para captar possíveis condicionamentos em relação ao tipo de verbo, nossos dados não deram margem a essa subdivisão, não compondo, portanto, um distintor.
} 
Os dados abaixo referem-se a cada um dos grupos:

\begin{tabular}{|l|lc|cc|cc|cc|cc|}
\hline & \multicolumn{2}{|c|}{$\begin{array}{c}\text { Jornal } \\
\text { Republicano }\end{array}$} & \multicolumn{2}{|c|}{$\begin{array}{c}\text { Imprensa } \\
\text { Jesuítica }\end{array}$} & $\begin{array}{c}\text { Intelectuais } \\
\text { católicos }\end{array}$ & Eclesiásticos & \multicolumn{2}{|c|}{ Total } \\
\hline clVV & 2 & $20 \%$ & 22 & $50 \%$ & 28 & $45,2 \%$ & 11 & $55 \%$ & 63 & $46,3 \%$ \\
\hline V-cl V & 2 & $20 \%$ & 4 & $9,1 \%$ & 0 & - & 2 & $10 \%$ & 8 & $5,9 \%$ \\
\hline VV-cl & 4 & $40 \%$ & 14 & $31,8 \%$ & 32 & $51,6 \%$ & 5 & $25 \%$ & 55 & $40,4 \%$ \\
\hline V clV & 2 & $20 \%$ & 4 & $9,1 \%$ & 2 & $3,2 \%$ & 2 & $10 \%$ & 10 & $7,4 \%$ \\
\hline
\end{tabular}

Tabela 7: Distribuição dos clíticos nos grupos verbais: comunidades de prática

Em termos gerais, o que se observa é que as posições mais marcadas são as mesmas encontradas por Santos Silva (2012) na escrita dos intelectuais paulistas (cIVV com $45 \%$ e VVcl com 37\%). Schei (2010) identificou $81 \%$ de $\mathrm{VVcl}$ e $17 \%$ de clVV nas narrativas; $50 \%$ de ênclise ao verbo principal ( $V$-cl V), $34 \%$ de próclise ao verbo principal (cIVV) nos diálogos, gênero em que começa a se manifestar a próclise ao segundo verbo ( $\mathrm{V} \mathrm{clV}, 15 \%)$, que veio marcar o português brasileiro.

No que concerne aos grupos verbais, nem a sintaxe dos intelectuais paulistas analisada por Santos Silva (2012) nem a sintaxe das comunidades de prática em exame se aproximam do vernáculo à época, pois a ênclise ao verbo principal é o contexto menos expressivo nesse material.

A distribuição da posição pós-verbal ( $\mathrm{VVcl})$, sem alçamento, ocorre com mais frequência entre os Intelectuais e na Imprensa Republicana, afirmando-se com a presença de atrator ou não: 


\section{Com atrator}

(34) e os élos de responsabilidade, em que devem encadear-se as phrases de quem aconselha. [PORCHAT]

(35) (...) preguem e outros que queiram adoptal-o como religião. [FED22/1908-148]

(36) (...) com o brio de quem não dobra os joelhos a queimar incenso á devassidão e á podridão, é que nos podemos gloriar os Padres Catholicos de que inoculando na mocidade os principios religiosos fundamentamos sobre bases solidas o mais lisongeiro porvir para a sociedade. [PE.FIALHO]

\section{Sem atrator}

(37) Ahi, vamos encontral-os levantando a cruz, orando, convertendo, aconselhando, curando, ensinando, cultivando e edificando aquelles templos que vieram até os nossos dias como attestados de seu poder e de sua grandesa. [PRESTES]

(38) (...) os diplomados no Collegio S. Luiz sabem formar-se cidadãos dignos de defender com altivez, e de amar entranhadamente o nosso formoso Brasil. [PORCHAT]

(39) Deus tomou entre suas mãos santificadoras o vaso, que o mundo tivera por perdido e desestimado num canto desta casa e quiz afeiçoal-o em vaso de honra, vas in honorem; [BRASILIO MACHADO]

Assim, o grupo formado pelos "não-eclesiásticos" (i.e., Intelectuais e Jornal Republicano) opta pela não subida do clítico (VVcl: 51,6\% e 40\%, respectivamente). Já os Eclesiásticos e a Imprensa Jesuítica adotam preferencialmente a colocação pronominal resultante de movimento (cIVV: $55 \%$ e 50\%, respectivamente). Também nos grupos verbais a sintaxe jesuítica se mostra mais proclítica e a sintaxe republicana mais enclítica. 


\subsubsection{A interpolação}

Foram computadas separadamente as construções negativas, pois há a possibilidade de o clítico se separar do verbo pela interveniência do elemento negativo. Nesses casos ocorre a interpolação da negação, fenômeno bastante presente no contexto de próclise obrigatória (orações dependentes) que permeou outros contextos sintáticos (orações principais, independentes e $2^{\text {a }}$. coordenadas), ao longo dos séculos.

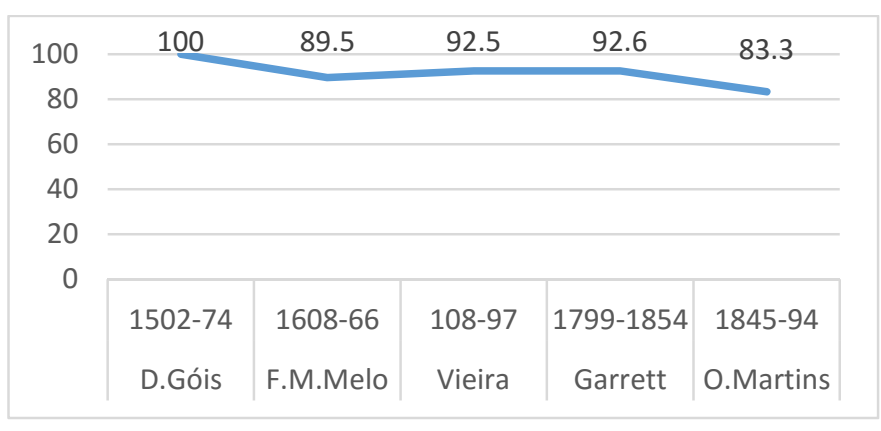

Gráfico 3: Interpolação da negação ao longo dos séculos (Adaptado de Martins, 1997)

Entretanto, no Português Moderno, o movimento do clítico em contexto de negação se torna opcional (NAMIUTI, 2008). Já no português brasileiro, concomitantemente à perda da propriedade de cliticizar-se às posições mais altas da sentença, a interpolação vai saindo de cena. Com efeito, o fenômeno da interpolação começa a decrescer no português Europeu no século XIX, como mostra o gráfico acima com dados extraídos de Martins (1997). No Português do Brasil, a interpolação que tem percentual abaixo de $20 \%$ no século XVIII apresenta-se residual no século XIX (CYRINO, 1993; PAGOTTO, 1992).

Registramos 19 casos de estruturas negativas com a presença de clíticos. Nas estruturas sem alçamento de clítico (VVcl, 8 ocorrências e V clV, 1 ocorrência), não foi identificado o fenômeno da interpolação. Nas estruturas com alçamento de clítico, foram registrados 10 casos de $c / V V$, entre os quais se verificaram 4 casos de interpolação, os 
quais aparecem apenas no material jesuítico, na Revista Mensageiro do Coração de Jesus e nos dados de um eclesiástico, Pe. Fialho, SJ, em estruturas que apresentam como antecedentes termos subordinativos:

(40) (...) e como os não sabia ler, pedia a pessoas caritativas que Ih'os lessem (...) [MCJ]

(41) (...) que as muitas occupações nos não devem impedir a leitura assidua (...) [MCJ]

(42) Ai! Que eu sei, que o terdes sido alumnos deste collegio será o alvo, para onde hão de convergir os remoques e escarneos semsaborões e impios dos que vos não poderão ter por cumplices do que não cabe na lingua dizer deste logar sagrado. [PE.FIALHO]

Poderíamos associar a interpolação encontrada no material jesuítico às leituras feitas pelo grupo religioso, como os textos de Pe. Antônio Vieira, entre outros, que servem de base de emulação, caso em que essa colocação seria interpretada como uma tentativa de alinhamento aos textos lidos e ensinados pelo grupo de padres detentores da educação formal da elite paulista. Entretanto, ainda que a interpolação não tenha sido encontrada no material republicano, os resultados de Martins (1997) apontam a alta frequência da interpolação no $\mathrm{PE}$, o que indicia que não é necessário apelar para a gramática de Vieira para explicar os usos jesuíticos do final do século XIX. Além disso, as ocorrências de interpolação são baixas, o que sugere uma conexão com a mudança em curso no português brasileiro de não alçamento do clítico. 


\subsubsection{Colocação pronominal em perspectiva: o caso das infinitivas}

\subsubsection{A moldura pronominal: orações infinitivas ${ }^{99}$}

Tomando o fenômeno linguístico da colocação pronominal como lente para mapear as duas balizas, fala e escrita da variedade brasileira de língua portuguesa, Oliveira (2011), ao compulsar as gramáticas oitocentistas, observou que o ambiente sintático menos marcado era o das infinitivas preposicionadas (ex. deixou de the dizerldizer-lhe; começou a Ihe falar/falar-Ihe). Não se apontava como brasileirismo bem como não se condenava o uso de uma ou outra colocação pronominal.

Sendo um contexto sintático pouco sujeito à estigmatização ${ }^{100}$, do qual os compêndios gramaticais pouco se ocupam, a colocação pronominal em estruturas infinitivas estava livre das amarras normativas e poderia ser tratada como ambiente de variação, sujeita a fatores extralinguísticos. Essa constatação levou à suposição de que o ambiente sintático das infinitivas preposicionadas seria um dos contextos ideais para vincular a conjuntura à análise linguística. Esse ambiente menos controlado pode ser constatado ao analisar as gramáticas da época. No colégio jesuítico, a gramática de base para o ensino não revela nenhuma orientação sobre a colocação pronominal em contexto de infinitivas ${ }^{101}$.

Com efeito, o quadro das infinitivas preposicionadas nas produções literárias mostra diferenças entre o português do Brasil e o Português Europeu:

"A língua literária brasileira do século XIX, no entanto, não é igual nem ao $\mathrm{PE}$, nem ao $\mathrm{PB}$ atual: assemelha-se ao modelo lusitano por quase sempre empregar a ênclise com todos os pronomes depois da preposição

\footnotetext{
${ }^{99}$ Os estudos que elencamos nesta seção não consideram os casos de colocação pronominal sem a presença de preposição. Incluiremos esse contexto em nossos dados.

${ }^{100}$ O contexto de subordinadas, por exemplo, foi alvo de atenção dos gramáticos que, após a polêmica travada sobre a escrita de José de Alencar, assinalavam a ênclise como brasileirismo. A partir daí, é visível o decréscimo do uso da ênclise no contexto de subordinadas.

${ }^{101}$ Como abordado no Capítulo 2, a gramática adotada no colégio para o ensino nas aulas das primeiras séries orientava apenas para o bom uso dos oblíquos, mas sem a discussão da ordem sentencial.
} 
a mas, ao contrário do $\mathrm{PE}$, com as demais preposições prevalece a ênclise". (SCHEI, 2010, p.67)

Em amostra constituída de cartas pessoais de escritores brasileiros e portugueses escritas ao longo do século XIX e na primeira década do século XX, o estudo revelou a existência de dois quadros diferentes de colocação pronominal. Entre os brasileiros evidenciou-se uma mudança linguística: a preferência pela colocação enclítica nos textos dos escritores românticos José de Alencar e Álvares de Azevedo é abandonada em favor da próclise por Machado de Assis, Lima Barreto e Mario de Andrade. Por sua vez, as cartas pessoais dos escritores portugueses manifestavam um sistema dual, caracterizado pelo uso categórico da ênclise junto à preposição "a" e da próclise no ambiente das demais preposições, mantendo-se estável ao longo do período. Seguemse exemplos do sistema dual português, tomado como parâmetro para a discussão:

(m) Cada queijo, [...] pode vir a custar-te, a ti Jacinto queijeiro... (E.Queirós, CeS, p.230)

(n) ...parava, imóvel, [...] , para se embeber de silêncio e de paz... (E.Queirós, CeS, p.215)

(o) O vasto Pimentinha, [...], não cessava de nos contemplar (E.Queirós, CeS, p. 188)

No gráfico a seguir, estão os dados dos escritores portugueses em relação ao tipo de preposição:

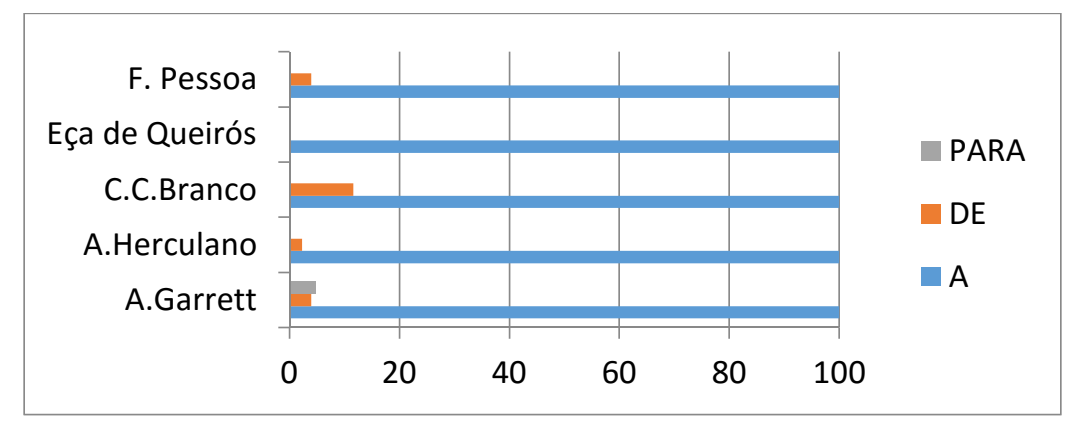

Gráfico 4- Ênclise em orações infinitivas preposicionadas:

Escritores portugueses oitocentistas ${ }^{102}$ (Adaptado de Oliveira, 2011)

\footnotetext{
102 As tabelas com os números de ocorrências/estatísticos podem ser consultadas nos "anexos", ao fim deste trabalho.
} 
O gráfico mostra a estabilidade e a especialização da ênclise no ambiente da preposição "a" e da próclise na presença das demais preposições, quadro linguístico que não se repete para os escritores brasileiros:

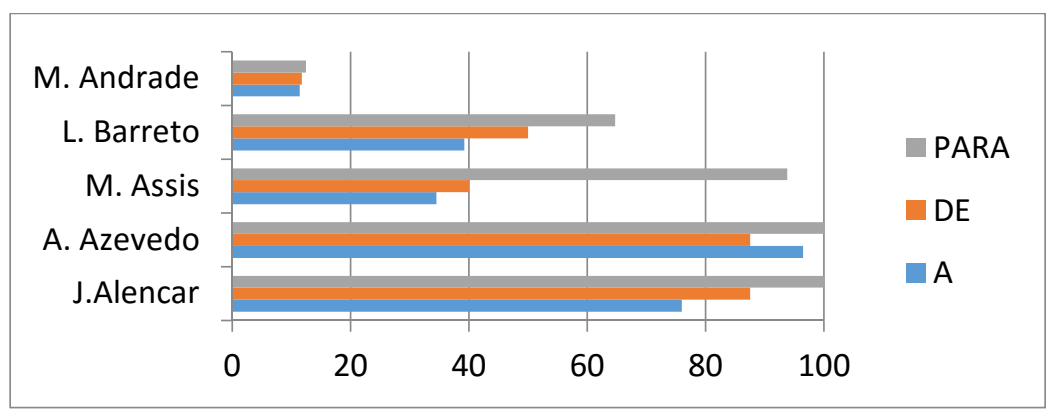

Gráfico 5: Ênclise em orações infinitivas preposicionadas: Escritores brasileiros (Adaptado de Oliveira, 2011)

Os resultados obtidos na análise da colocação pronominal no contexto das infinitivas preposicionadas mostram que os literatos brasileiros não adotavam o modelo português, uma vez que o contexto da preposição "a" é permeável à próclise, resultados semelhantes àqueles encontrados por Schei (2010): faixa de $20 \%$ entre os românticos e $50 \%$ entre os realistas.

Ao analisar a colocação pronominal nas infinitivas preposicionadas em correspondências de circulação pública, Oliveira (2013) observou que, contrariamente à tendência à próclise verificada nas cartas dos escritores da virada do século XIX-XX, os autores incrementavam o uso da ênclise, como mostra o gráfico abaixo: 


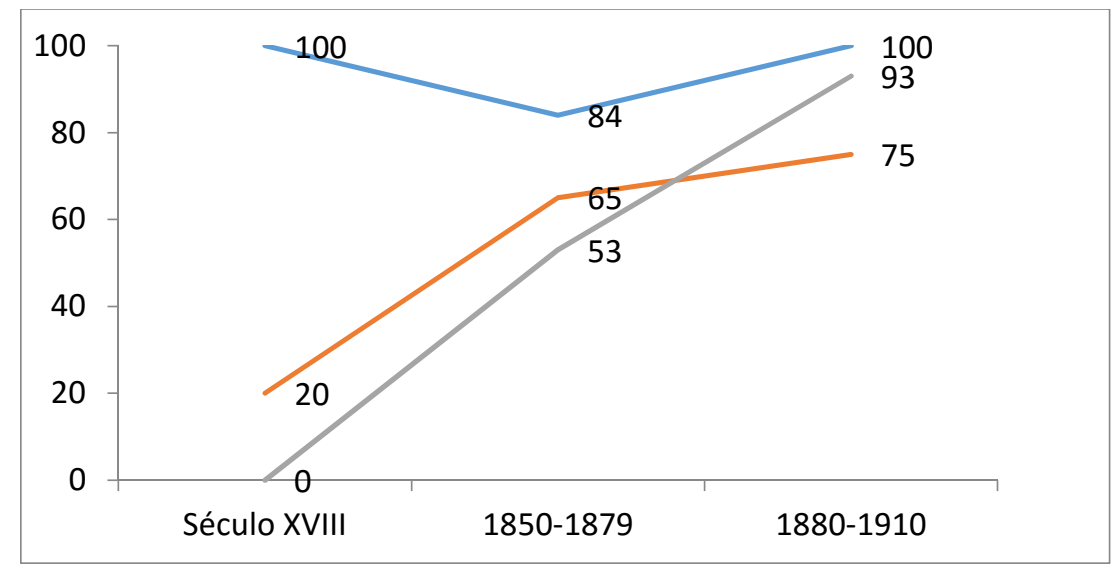

Gráfico 6 - Ênclise em orações infinitivas preposicionadas:

Correspondência de circulação pública escrita no Brasil (Adaptado de Oliveira, 2013)

Se a correspondência do período colonial (século XVIII) atendia ao modelo português, a do período do Brasil independente ${ }^{103}$ quebrava o modelo dual e optava pela generalização da ênclise em crescimento ao longo do século. O contraste entre a gramática dos escritores e a dos intelectuais políticos (próclise e ênclise, respectivamente) estava em consonância com a clivagem da classe intelectual ocorrida a partir do movimento de 1870 (ALONSO, 2002): na 1a. metade do século XIX os escritores eram a um só tempo intelectuais e políticos; no final do século os escritores não ocupam cargo político e passam a usar uma gramática que ecoa o vernáculo. Os políticos, por sua vez, tendem a acentuar o uso da ênclise, afastando-se do vernáculo que vinha se fixando.

Assim, a virada do século XX era marcada por um padrão vernacular proclítico, assinalado nos textos dos literatos, e por um padrão de escrita enclítico, tal como se observa nas correspondências dos intelectuais que ocupavam posições políticas. Tal interpretação ganha suporte com a análise dos discursos parlamentares que também repercutem a ênclise generalizada (OLIVEIRA, 2014).

\footnotetext{
${ }^{103}$ Entre a série de mudanças ocorridas no Brasil na primeira metade do século XIX estão, além da Independência de 1822, o manifesto romântico de 1836, a criação do Instituto Histórico e Geográfico de 1838 e diversas manifestações espalhadas pelo país. Esses eventos definem o forte desejo de autonomia que circulava e o esforço de valorização da realidade local.
} 
O emprego maciço da ênclise também foi observado por Santos Silva (2012) nos textos produzidos por intelectuais paulistas republicanos formados pela Academia de Direito do Largo São Francisco, entre eles, Alberto Salles, Campos Salles, Prudente de Moraes e Rodrigues Alves ${ }^{104}$. A autora, seguindo os parâmetros de análise de Oliveira (2011), detectou a gramática enclítica em sua produção e atribuiu-lhe condicionantes culturais, a saber a formação dos autores na Academia de Direito. A passagem pela Academia tanto dos escritores românticos quanto dos intelectuais republicanos explicaria a seleção da gramática que privilegia a ênclise:

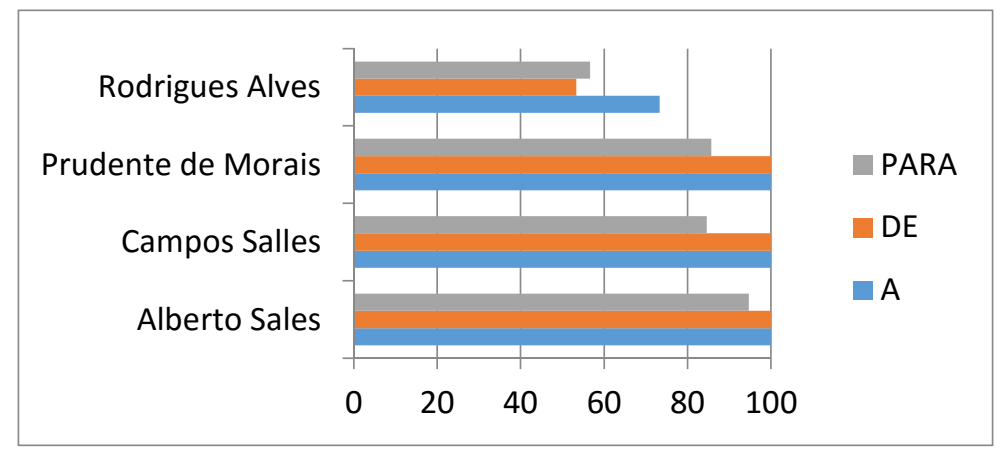

Gráfico 7 - Ênclise em orações infinitivas preposicionadas Intelectuais republicanos paulistas (Adaptado de Santos Silva, 2012)

Interpretados à luz da conjuntura política e cultural, os resultados afastam a hipótese do português europeu como modelo e apontam dois percursos para a padronização linguística na virada do século XX: um que assumia a próclise vernacular, normalmente associada às classes sociais menos favorecidas, e um que ecoava a gramática da classe sócio-política que selecionada a ênclise como marca identitária para se contrapor a outras classes intelectuais emergentes (OLIVEIRA, 2014).

\footnotetext{
104 Embora Rodrigues Alves tenha ocupado a pasta presidencial da República, ele também ocupara cargos administrativos do governo monárquico.
} 


\subsubsection{Traçados pronominais nas infinitivas preposicionadas}

Conforme os estudos precedentes relembrados acima, verificamos três modelos de colocação pronominal nas infinitivas:

1- o vernáculo brasileiro na virada do século $X X$, que privilegia a próclise independentemente do tipo de preposição;

2- o modelo dos escritores românticos brasileiros relacionados à elite política do começo do século XIX, em que a ênclise, apesar de altos índices de frequência, não é categórica;

3- o modelo republicano paulista, no qual a ênclise é categórica.

Os dados gerais da ênclise nas infinitivas em nosso corpus atingiram a expressão numérica de 111/153 ocorrências, perfazendo o total de 72,5\%. Esse perfil gramatical se opõe drasticamente ao da colocação pronominal nas orações finitas (26\%). Vale ressaltar que o verbo no infinitivo é contexto esperado de ênclise, mas a presença de preposição altera essa configuração.

Dessa forma, distinguimos as duas possibilidades de apresentação das infinitivas no corpus, isto é, ausência de preposição e presença de uma preposição ${ }^{105}$ :

\section{Sem preposição}

(43) [...] parecia conveniente entregar-Ihe antes uma espada (...)" [MCJ21]

(44) [...] não basta reter na memoria os mandamentos de Deus, e esquecel-os nas obras;" [MCJ21]

\footnotetext{
${ }^{105}$ Além das preposições a, de e para, ocorreram ainda, em números percentuais baixos, as preposições em, sem, com, por, até, que foram agrupadas com a designação de outras. Na computação da ênclise, obtivemos 9/11, perfazendo $82 \%$ dessa colocação.
} 


\section{Com preposição}

(45) Todos se edificaram, se julgaram felizes de se approximar dele [COSTA1906]

(46) [...] que tem sabido corresponder aos esforços paternos para Ihe dar uma solida instrucção e uma educação aprimorada. [LEAL1909]

(47) [...] Mas nem é preciso defrontar a complexidade dos phenomenos biologicos, para sentir-se a grande responsabilidade pelas affirmações feitas em nome da sciencia. [PORCHAT1904]

(48) É, como Vigario de Christo, a representação immediata e visivel do Pontificado divino, o signal manifesto e efficaz da presença de Deus, do Deus, que na pessôa de Pedro, a se reproduzir, de Pontifice em Pontifice, nella falla, nella doutrina, nella governa. [MACHADO1906]

(49) [...] um refluxo da alma do santo a espalhar-se no seu saber que illumina [PRESTES1910]

(50) [...] não hesitam em expressal-a com louvavel franqueza. [PORCHAT1904]

No cômputo geral dos dados, a ênclise foi determinante em contextos sem preposição: 38/45 (84\%) e nos contextos com preposição: 73/108 (67,6\%). Na subdivisão por tipo de preposição, obtivemos a seguinte distribuição:

\begin{tabular}{|l|rr|}
\hline A & $19 / 26$ & $73 \%$ \\
\hline De & $20 / 36$ & $55,5 \%$ \\
\hline Para & $24 / 34$ & $70,5 \%$ \\
\hline Outras & $10 / 12$ & $83 \%$ \\
\hline
\end{tabular}

Tabela 8: Ênclise nas infinitivas preposicionadas por tipo de preposição

A primeira observação a ser feita é que esses índices percentuais mostram claramente que a gramática dessa variedade linguística não se modela pelo Português Europeu, pois a ênclise coocorre com todos os tipos de preposição. 
A tabela abaixo traz a comparação dos usos da ênclise nas infinitivas preposicionadas entre a Imprensa Republicana, a Imprensa Jesuítica, os Eclesiásticos e os Intelectuais Católicos:

\begin{tabular}{|c|c|c|c|c|c|c|}
\hline & \multicolumn{2}{|c|}{$\begin{array}{c}\text { Jornal } \\
\text { Republicano }\end{array}$} & $\begin{array}{l}\text { Imprensa } \\
\text { Jesuítica }\end{array}$ & $\begin{array}{l}\text { Intelectuais } \\
\text { Católicos }\end{array}$ & \multicolumn{2}{|c|}{ Eclesiásticos } \\
\hline A & & $67 \%$ & $3 / 7 \quad 43 \%$ & $5 / 6 \quad 83 \%$ & $9 / 10$ & $90 \%$ \\
\hline $\mathrm{DE}$ & & $50 \%$ & $11 / 23 \quad 48 \%$ & $5 / 5 \quad 100 \%$ & $3 / 6$ & $50 \%$ \\
\hline PARA & & $67 \%$ & $8 / 12 \quad 67 \%$ & $9 / 13 \quad 69 \%$ & $5 / 6$ & $83 \%$ \\
\hline OUTRAS & $1 / 2$ & $50 \%$ & $1 / 1 \quad 100 \%$ & $5 / 5 \quad 100 \%$ & $3 / 4$ & $75 \%$ \\
\hline TOTAL & $6 / 10$ & & $23 / 43$ & $24 / 29$ & $20 / 26$ & \\
\hline
\end{tabular}

Tabela 9: Ênclise nas infinitivas preposicionadas por grupo e tipo de preposição

A comparação entre os grupos nos aponta, mais uma vez, para as condições de produção envolvidas, pois nos discursos de Intelectuais Católicos e Eclesiásticos, a ênclise aparece com mais força do que na escrita da imprensa, seja Jesuítica ou Republicana. Contrariamente às nossas expectativas, embora a presença da ênclise no Jornal Republicano seja maior do que na Imprensa Jesuítica, seus valores são relativamente baixos em termos percentuais. Entretanto, há de se ressaltar que o número de ocorrências para as infinitivas preposicionadas, de uma maneira geral, e para o Jornal Republicano, em particular, é um impeditivo para conclusões sobre a colocação pronominal nesse ambiente sintático.

Vale a pena, entretanto, sublinhar que, diferentemente das orações finitas, a ênclise se faz mais presente nas infinitivas dos textos discursivos. Considerando a ostentação e a "correção gramatical" como preceito retórico, de um lado, e o paradigma civilizatório associado à ênclise pronominal, de outro, pode-se inferir que a colocação enclítica é índice civilizatório no contexto das infinitivas (e de verbo em primeira posição); nos demais contextos sintáticos, a colocação pronominal não é associada a esse paradigma, o que explica o avanço da variação. 
Se os dados da Imprensa Jesuítica diferem daqueles computados por outros grupos, vale pensar na motivação que os jesuítas tiveram para tal sintaxe. Não seria o caso dos jesuítas estarem emulando a sintaxe dos textos de referência, as leituras canônicas de um grupo que procura na tradição os modelos a serem seguidos? $\mathrm{Na}$ próxima seção, apresentamos os dados do Português seiscentista de outros jesuítas que serviram de motivação intelectual para os jesuítas do interior paulista. A pergunta aberta é o quanto a sintaxe das leituras feitas pelo grupo de religiosos pode afetar as suas práticas discursivas e sintáticas.

\subsubsection{De jesuíta a jesuíta: de Vieira ao interior paulista}

Godoy (2006), partindo de uma quantificação do corpus Tycho Brahe ${ }^{106}$ para diversos dados do Português clássico ao moderno, mostra a ascendência de uma sintaxe enclítica entre os séculos XVI e XVIII, independentemente do tipo de preposição. Entretanto, a partir do século XVIII, apenas a preposição "a" engatilha a ênclise; as demais preposições favorecem a próclise, consolidando-se já no século XVIII o modelo português:

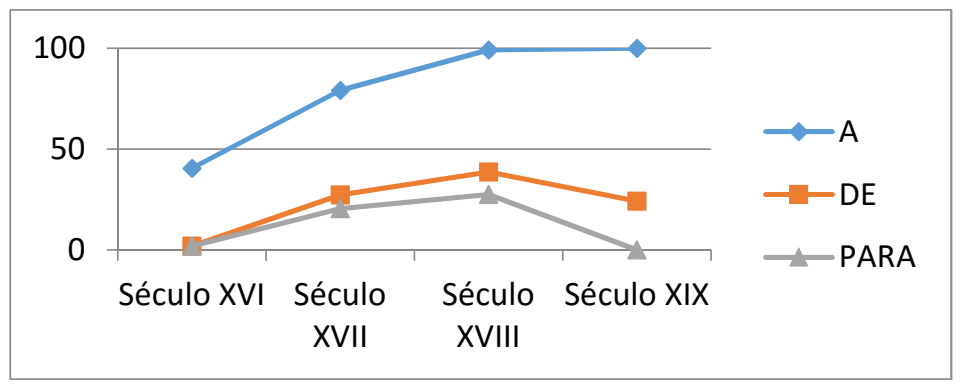

Gráfico 8 - Ênclise em orações infinitivas preposicionadas: Escritores portugueses (Adaptado de Godoy, 2006)

A análise diacrônica realizada pela autora inclui dados extraídos de textos de dois jesuítas: Padre Antônio Vieira e Pe. Manuel da Costa ${ }^{107}$. Interessa saber qual é o modelo

\footnotetext{
${ }^{106}$ Os dados integram o corpus eletrônico, construído pela Universidade de Campinas, nos moldes do Penn-Helsinki Parsed Corpus of Middle English, recebendo um etiquetador que possibilita a busca automática de palavras e sequências de texto, facilitando o trabalho com grande número de dados.

107 Ao padre jesuíta Manuel da Costa (1601-1667), atribui-se a composição da obra intitulada "Arte de Furtar", redigida em 1652, da qual foram retirados os dados para quantificação do pronome.
} 
de colocação pronominal usado pelo jesuíta nessa época ${ }^{108}$ para estabelecer parâmetros de comparação com os resultados da análise dos textos produzidos pelos jesuítas do século XIX, fonte de nosso estudo. Embora pareça uma comparação anacrônica, a justificativa reside na própria história e tradição educacional da Companhia, que, pelo uso do Ratio Studiorum, estabelece uma continuidade no quadro de leituras e de técnicas de escrita.

O quadro abaixo opõe a colocação pronominal dos jesuítas (Manuel da Cosa e Antônio Vieira) aos demais autores, por trazerem um sistema dual de colocação pronominal, cujo desenho lembra o sistema dual do português europeu moderno. Embora o sistema dual também seja adotado por Vieira, o percentual de ênclise no contexto da preposição "a" (único contexto em que a ênclise aparece) é bastante baixo:

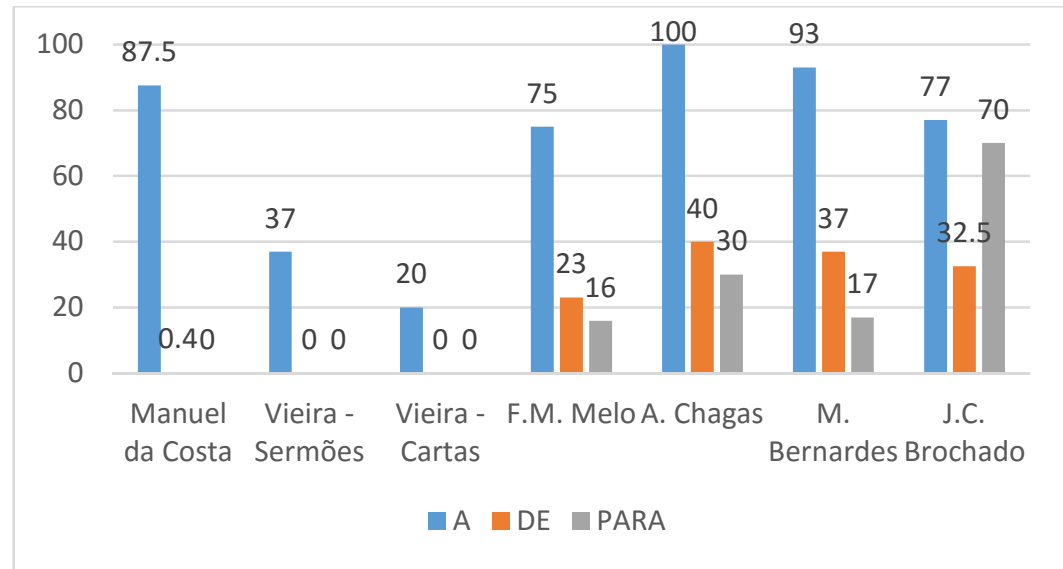

Gráfico 9 - Ênclise em infinitivas preposicionadas: Autores portugueses seiscentistas (Adaptado de Godoy, 2006)

Apesar da diferença entre as gramáticas dos dois jesuítas (índice expressivo de ênclise no contexto de a no texto de Manuel da Costa e baixa representatividade nos textos de Vieira), os religiosos são os únicos a usarem de forma categórica a próclise

\footnotetext{
${ }^{108}$ Devemos relembrar que o Brasil a esse tempo era um estado ultramarino português e que a discussão sobre as diferenças entre português e brasileiro não existia para o homem desse período. Esse comentário se faz pertinente por Vieira ter nascido em Portugal, mas ter vivido grande parte de sua vida no Brasil.
} 
para as preposições de e para, ou seja, os jesuítas encontram-se na contramão da colocação pronominal dos demais escritores de seu século ${ }^{109}$.

Se comutarmos esses dados com a análise dos religiosos (Eclesiásticos e Imprensa Jesuítica), notamos que, embora seja na Imprensa Jesuítica que se encontre o número mais alto de próclise, a sintaxe de colocação não é a mesma encontrada junto aos padres seiscentistas. Vejamos:

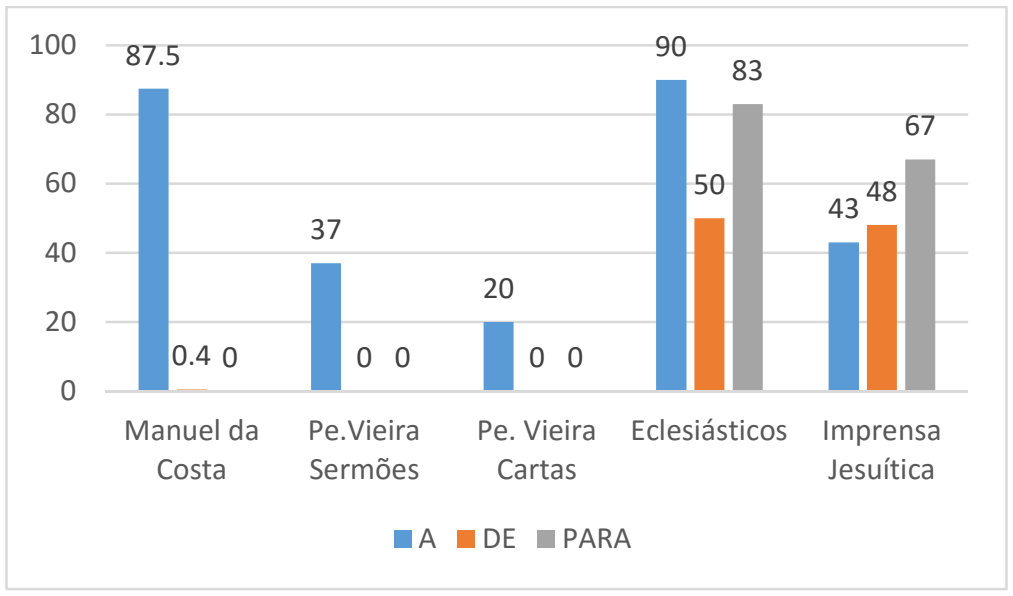

Gráfico 10 - Ênclise em infinitivas por tipo de preposição: Comparação jesuítas entre séculos

O desenho gráfico da ênclise nos textos de Eclesiásticos e da Imprensa Jesuítica é diferente daquele que evoca a gramática nas produções textuais do Padre Vieira e do Padre Manuel da Costa. Esses resultados fazem inferir que os religiosos ituanos não adotam a gramática dos padres seiscentistas. Os jesuítas não adotam a gramática encontrada nas leituras que emulam no plano discursivo, também não seguem o modelo do português moderno. Parece ocorrer alinhamento sintático ao grupo dos Intelectuais Católicos, que, ainda que façam largo uso da ênclise, não adotam a generalização dessa colocação pronominal característica da gramática dos intelectuais republicanos

109 Para os dados do Português medieval, consultar MARTINS, 1994 e CARVALHO, 2010. 
(SANTOS SILVA, 2012). Vale salientar que a imprensa local, e em particular o Jornal republicano da cidade de Itu, não reflete o uso dos intelectuais republicanos.

\section{Considerações Finais}

A definição de comunidades de práticas e a comparação dos dados da Imprensa Jesuítica com os textos da Imprensa leiga (republicana), do grupo dos Intelectuais Católicos e Eclesiásticos mostrou-se como elemento relevante para a pesquisa, pois fez emergir resultados mais específicos sobre as ações e práticas dos grupos para a compreensão da variação na complexa inter-relação e intersecção das dinâmicas sociais.

Como resposta às indagações que este capítulo pretendeu produzir sobre a sintaxe da comunidade jesuítica ituana, consideramos que a quantificação dos dados descortinou, em relação a alguns contextos, um comportamento menos atuante da ênclise, o que poderia levar à interpretação de que a gramática jesuítica se alinha à tendência mais vernacular que caracterizava a ascendência da próclise no português brasileiro. Entretanto, há contextos sintáticos, como as infinitivas preposicionadas, em que a ênclise impera, o que nos leva a afastar a gramática jesuítica do vernáculo.

No caso das finitas, a atuação de um fator extralinguístico foi determinante na amostragem: a condição de produção dos textos. A Imprensa Jesuítica emparelhada ao Jornal Republicano, apresenta resultados mais altos de ênclise nas orações Independentes; enquanto, nos discursos de Eclesiásticos, há predomínio da próclise. Associamos esse resultado com escolhas conscientes dos sujeitos frente aos embates sociais, pois o jornal é o gênero por excelência na dinâmica das relações e nos posicionamentos entre os grupos. E, nesse sentido, imaginamos o cenário das lutas de poder que a imprensa pode representar, num palco onde figura a difícil batalha pela empreitada da educação da elite paulista. 
Nas infinitivas, ao comparar os resultados encontrados em estudos anteriores, correspondentes aos três modelos de colocação pronominal, observamos que a colocação pronominal segue o padrão dos escritores intelectuais que tinham uma passagem pela Academia de Direito do Largo de S. Francisco, mas que, em certa medida, distanciavam-se daqueles que, apesar da mesma formação, estavam comprometidos com o regime republicano, os quais adotavam como marca linguística de sua posição social a ênclise categórica (SANTOS SILVA, 2012).

A análise da colocação pronominal mostrou ainda que, apesar de a ênclise ser a colocação pronominal que colocava a língua falada no Brasil nos moldes civilizatórios, como sugerem Pagotto (1998), Oliveira (2011) e Santos Silva (2012), não eram todos os contextos sintáticos que orientavam a colocação pronominal "civilizada". As orações independentes (matrizes e $2^{\text {a }}$. coordenadas), normalmente tidas como contexto de variação, não vinculam a colocação pronominal à chancela da "civilização", pois, se assim não fosse, os índices de ênclise teriam se mostrado mais altos.

Ao contrário, o início absoluto de sentença e as infinitivas preposicionadas se revelaram contextos propiciadores do vínculo entre gramática e "civilização", pois nesses ambientes grassa a ênclise. Um dos aspectos salientes para a discussão da colocação pronominal nas infinitivas preposicionadas é o gênero textual. Os textos jornalísticos são mais proclíticos (o jesuítico mais ainda do que o republicano) já os discursos são bem mais enclíticos. Essa diferença está em consonância com o preceito retórico da "correção gramatical" e da ornamentação. A ênclise, como versão linguística do paradigma civilizatório, está, portanto, presente nos discursos proferidos nas cerimônias do Colégio S. Luiz. Já nas orações independentes em que não se observa o binômio ênclisecivilização, a ênclise é bem menos presente nos discursos do que na imprensa, ou seja, a ênclise não faz parte da estratégia de ornamentação retórica nesse ambiente sintático.

A análise entre gramáticas de séculos diferentes nos mostrou que, embora a tradição de ensino e de retórica da Companhia de Jesus, tendo Padre Antônio Vieira e o Padre Manuel da Costa como modelos de emulação nos compêndios das aulas de Gramática, Humanidades e Retórica no colégio ituano, como definem os parâmetros 197 
estipulados no documento máximo da educação jesuítica, o Ratio Studiorum, a colocação pronominal do jesuíta seiscentista não é tomada como modelo pela comunidade de prática dos religiosos.

Uma das motivações para o distanciamento da gramática jesuítica seiscentista está na atuação do Pe. Antonio Honorati, diretor do Colégio, que retomava os sermões de Vieira para ensinar os alunos: "No ano de 1867, sendo eu diretor do colégio de S. Luiz na Provincia de S. Paulo no Brasil, tinha-me determinado a tirar dos sermões de Vieira uns excertos para uso de meus alunos, como via ter feito Antonio Feliciano de Castilho com as obras de Bernardes ${ }^{110 "}$. O fato é que Honorati interferiu nos textos de Vieira para alterar interpretações das Escrituras que supunha "forçadas, inconvenientes e talvez falsas", o que fazia por meio da eliminação de citações de autores profanos, da rasura de exagerações e de torneios sintáticos, emendando a codificação retórica de Vieira, de modo a "moralizar" o sermão e torná-lo "exemplo didático no ensino da eloquência sacra em seminários" e "modelo de pregação escolástica, apta a enfrentar a propaganda protestante" 111 .

O processo de "moralização" ou de higienização dos textos de Vieira realizado pelo diretor do Colégio $S$. Luiz deve ter atualizado também as regras de colocação pronominal, - afinal, esse fenômeno linguístico era "fetiche gramatical" do final do século XIX - emparelhando o padrão gramatical jesuítico ao dos leigos, representados no nosso trabalho pelo Jornal Republicano e pelos discursos de Intelectuais Católicos.

A colocação pronominal dos Eclesiásticos se aproxima daquela escolhida pela elite intelectual brasileira do final do século XIX, aqui representada pelos oradores de renome que discursaram no colégio, os quais tiveram, na sua maioria, formação e atuação na Academia de Direito do Largo São Francisco, locus em que atuava, no final do século XIX, um pequeno grupo de defensores da instituição católica, por meio de

\footnotetext{
110 Prólogo do 3‥ Tomo da obra: O Crysostomo Portuguez ou O Padre Antonio Vieira da Companhia de Jesus n'um Ensaio de Eloquencia Compilado de seus Sermões, quatro volumes editados em Lisboa pela Livraria Mattos Moreira, entre 1878 e 1881. (Agradeço ao Prof. João Hansen pela indicação do texto).

${ }^{111}$ Agradeço ao professor João Hansen pela informação.
} 
publicações e periódicos. O grupo tinha a convicção de que a Igreja poderia manter-se como um poder paralelo ao Estado, "podendo influenciar na sociedade brasileira, impondo seus princípio morais e religiosos, por ser detentora de um poder espiritual soberano"(AZZI, 2005).

O grupo de Intelectuais Católicos atuava promovendo a propagação da fé cristã e os valores da monarquia, visando a alicerçar a formação social brasileira na instituição religiosa, e, como corolário, neutralizar os investimentos que o governo republicano vinha fazendo no âmbito da laicização da educação. É com esse grupo que vai se legitimar e autorizar a reinserção e a permanência do grupo de jesuítas em São Paulo. Nessa conjuntura sócio-histórica, o modelo de colocação pronominal escolhido pelos jesuítas, é coerente com aquele adotado pelos Intelectuais que os apoiavam politicamente.

Os documentos analisados revelaram, no plano discursivo, a disposição desses oradores para a filiação a um conjunto de ideias que se encontrava em oposição aos novos ideais civilizatórios da República. No plano sintático, a análise da colocação pronominal nos permitiu verificar diferenças entre o padrão culto de português no Brasil que se distanciava do padrão europeu e da modalidade vernácula brasileira, e que constituía uma variante própria de uma parcela da elite intelectual que se coloca contrária à às investidas republicanas na laicização do ensino.

A sistematização de um parâmetro próprio de colocação pronominal para a elite econômica e intelectual repercute a relação da sintaxe com o habitus da comunidade, evidenciando a composição do português paulista no âmbito de um projeto político amplo da elite local, como diria Pagotto (1998), não com o olhar voltado para a Europa, como supõe o autor, mas com o olhar voltado para uma tradição brasileira que vinha se forjando no curso do século XIX, como propõe Oliveira (2011, 2013 e 2014). No caso dos jesuítas do interior paulista, a escolha pelo emprego da ênclise nas infinitivas preposicionadas tem o perfil daquela usada pela elite intelectual que os assegurava como grupo estabelecido, reproduzindo-a por meio da socialização de valores do grupo nas formas de capital social e cultural. 


\section{Palavras finais}

Pretendemos finalizar com uma reflexão sobre o encaminhamento dado a este trabalho a partir do entrecruzamento da linguística e da sociologia na tarefa de captar a organização hierárquica e linguística dos jesuítas no interior paulista. A demanda requerida na delimitação do material de análise norteou o tratamento de dados linguísticos vinculado às práticas sociais. A própria apreensão do objeto de estudo se realizou a partir desse encaminhamento, uma vez que permitiu cavar as ações jesuíticas após a restauração, na primeira década do século $X X$, e examinar como essas se orientavam para uma ideologia civilizatória e para a memória apologética. $O$ entendimento do imaginário, da "voz" jesuítica, bem como da variedade linguística de colocação pronominal transmitida nos jornais, revistas e cerimônias se concretizou ao fazer emergir as relações orquestradas nas práticas políticas, culturais, sociais e linguísticas, o que, por outro viés de análise, não seria possível.

A incursão no campo da sociologia trouxe ainda uma discussão sobre as ferramentas metodológicas utilizadas na linguística. Obviamente, as duas áreas têm uma longa história de conexões, o que não pode ser negligenciado. A diferenciação, no entanto, se realizou no levantamento conceitual de grupo social, de habitus, de capital simbólico, relacional e em sua aplicação na pesquisa, apreendendo a linguagem como uma das esferas da experiência social do sujeito. Dos estudos "sociolinguísticos", mais especificamente aqueles produzidos pela sociolinguística variacionista, foi destacada a nova roupagem trazida pelas indagações de Eckert (2000) sobre as "comunidades de práticas" e o "estilo". A articulação de concepções de redes sociais, identidades e variação linguística, fundamentados na análise variacionista das redes sociais nos permitiu direcionar procedimentos que colocaram em evidência os sujeitos engajados em suas atividades, recuperando seus valores, seus comportamentos, suas opções estilísticas - salientando, enfim, as comunidades de prática envolvidas. Esse último conceito proporcionou uma organização metodológica e um tipo de análise específica: a comparação dos dados da Imprensa Jesuítica com os da Imprensa Republicana; do 
grupo dos Intelectuais Católicos e dos Eclesiásticos, o que se mostrou elemento relevante para a pesquisa e conduziu a resultados mais específicos sobre as práticas dos grupos na escolha das variedades linguísticas. A delimitação esclareceu como o embate entre as variedades linguísticas é arquitetado na configuração social, com os grupos sociais em disputa.

Compusemos uma rede de concepções que nos pareceram fundamentais para tratar o objeto, acreditando que a interdisciplinaridade produzida aqui articulou esforços para a compreensão da "voz" jesuítica na complexa orquestração das práticas sociais. 


\section{FONTES DOCUMENTAIS}

\section{a) Acervo antigo do Colégio São Luís - São Paulo}

Fontes manuscritas:

Relação dos alumnos matriculados 1867 até 1892

Colégio São Luís - Matrícula dos Alumnos 1917-1933

\section{Fontes impressas:}

COSTA, Tristão Mariano da. Breve Notícia Histórica do Colégio São Luís, 1906 (datil.)

MACHADO, Brasilio; FIALHO, André; FONTOURA, Ezechias Galvão de; COSTA, Antonio de Macedo. Discursos. Panegíricos. In: Echo das Festas Collegiaes em honra a S. Luis Gonzaga e homenagem ao eminentíssimo senhor Cardeal D. Joaquim Arcoverde de Albuquerque Cavalcanti - Collegio S. Luiz. São Paulo: Duprat \& Cia, 1906

PORCHAT, Reinaldo; ARANTES, Altino; LAET, Carlos de; ALMEIDA JUNIOR, João Mendes de; LEAL, Eusebio I. Vaz Lobo da Camara; PRESTES, Julio. Discurso pronunciado no acto da collação de gráu aos bacharelandos em sciencias e lettras no Collegio S. Luiz em Ytu: 4 de dezembro de 1904. São Paulo: Typographia Brazil de Carlos Gerke \& Cia., 1904. 6 v.

Programma de ensino para os colégios da Cia de Jesus, 1864

Folheto publicitário - Colégio de São Luiz s/d

\section{b) Igreja do Senhor Bom Jesus - Itu}

Lettere edificanti dei PP. Della Compagnia di Gesù Della Provincia Romana

Catalogus Provinciae Romanae Soc. Jesu - Missio Brasiliensis - 1874 - 1909 
Catalogus Missiones Brasiliensis - Provinciae Romanae Soc. Jesu - 1909 - 1925

Revista "Mensageiro do Coração de Jesus" - seleção de textos 1900 a 1910

Jornal Federação - seleção de textos 1907 e 1908

Jornal A República - seleção de textos 1907 e 1908 


\section{REFERÊNCIAS BIBLIOGRÁFICAS}

ABAURRE, Maria Bernadete Marques \& GALVES, Charlotte. Os clíticos no português brasileiro: elementos para uma abordagem sintático-fonológica. In: Castilho, A.T., de e Basílio, M. (orgs.). Gramática do português falado, vol. IV - Estudos descritivos. Campinas: editora da UNICAMP, 1996.

ALENCAR, José de. O jesuíta. Obras completas. Rio de Janeiro: Aguilar, 1965, v.3.

ALENCAR, Mário de. (1919) Período Pronominal. In: PINTO, E.P. O Português do Brasil 1 (1820-1920). São Paulo: EDUSP, 1981, p. 457-468.

ALONSO, Ângela. Ideias em Movimento: a geração 1870 na crise do Brasil-Império. São Paulo: Paz e Terra, 2002.

AMARAL, Tania C.I. \& SECO, Ana Paula. Marquês de Pombal e a reforma educacional brasileira, no prelo, 2012.

ARNAULT, Cézar \& RUCKSTADTER, Massami Martins. Estrutura e organização das Constituições dos jesuítas (1539-1540). In: Acta Scientiarum. Maringá, v.25, n.1, 2002. p.103-113.

AUSTIN, J. L. Quando dizer é fazer. Porto Alegre: Artes Médicas, 1990.

AZZI, Riolando. Entre o trono e o altar: a Igreja Católica em São Paulo como poder espiritual. In: VILHENA, Maria Ângela \& PASSOS, João Décio. Presença Católica na História da cidade de São Paulo: Ed. Paulinas, 2005, p. 395-429.

BAKHTIN, Mikhail. Estética da Criação Verbal. Tradução de Paulo Bezerra, 2003, edição eletrônica.

. Marxismo e filosofia da linguagem.São Paulo: Hucitec, 2012.

BOURDIEU, P. Questões de Sociologia. Rio de Janeiro: Marco Zero, 1983a. 
. O Campo Científico. In: Ortiz, Renato (org.). Coleção Grandes Cientistas Sociais, n. 39, Editora Ática, São Paulo, 1983b.

. A economia das trocas simbólicas. São Paulo: Perspectiva, 1992.

A economia das trocas linguísticas. São Paulo: Edusp, 2008.

BRAIT, Beth. As vozes bakhtinianas e o diálogo inconcluso. In: BARROS, Diana L.P.; FIORIN, José L. (Orgs.) Dialogismo, polifonia, intertextualidade. São Paulo, SP: Edusp, 1999, p. 13

BURKE, Peter. Linguagens e comunidades nos primórdios da Europa Moderna. Trad. Cristina Yamagami. São Paulo: Editora UNESP, 2010.

CAMACHO, Roberto Gomes. Da linguística formal à linguística social. São Paulo: Parábola, 2013.

CARNEIRO, Zenaide de Oliveira Novais. Cartas brasileiras: um estudo linguístico filológico. Tese de Doutorado - Unicamp, 2005.

CARVALHO, José Murilo de. Os bestializados: o Rio de Janeiro e a República que não foi. São Paulo, Companhia das Letras, 1987.

CARVALHO, Maria José. Sintaxe e pragmática dos clíticos no português medieval. Matraga: Rio de Janeiro, v. 17, n.26, jan./jun.,2010, p. 113-131.

CASTILHO, Ataliba de. Nova Gramática do Português Brasileiro. Editora Contexto: São Paulo, 2010.

CAVALHEIRO, Diogo. Hegemonia católica e educação da elite em Itu (1851-1889), o Colégio N.S. do Patrocínio (feminino) e o Colégio de São Luiz de Gonzaga (masculino). Tese de doutorado, Universidade Metodista de Piracicaba, Piracicaba, 2001. 
CERTEAU, Michel. A Escrita da História. Trad. Maria de Lourdes Meneses. Rio de Janeiro: Forense Universitária, 2011.

CHAMBERS, J.K. Sociolinguistic Theory. Linguistic Variation and its Social Significance. Oxford/Cambridge: Blackwell, 1996.

COAN, Giovanna. Construções-se em anúncios publicitários de revistas paulistanas. Dissertação de mestrado, FFLCH/USP, 2011.

COMBLIN, Joseph. O provisório e o definitivo. São Paulo: Herder, 1968.

COSTA, Emília Viotti da. Da senzala à colônia, $2^{\mathrm{a}}$ ed. São Paulo: Ciências Humanas, 1982.

COSTA, Tristão Mariano da. Breve Notícia Histórica do Colégio São Luís, 1906 (manuscrito).

CURTIUS, Ernest. Literatura europeia e Idade Média latina. $2^{2}$ ed. Tradução Teodoro Cabral. Brasília: INL, 1979.

CYRINO, Sônia. Observações sobre a mudança diacrônica no português do Brasil: objeto nulo e clíticos. In: ROBERTS, I. e KATO, M.A. (orgs.), Português Brasileiro: uma viagem diacrônica do português brasileiro, $2^{\mathrm{a}}$ ed. Campinas: Editora da Unicamp, 1996 [1993], p. 163-184.

DOMINGOS, Simone Tiago. Política e memória: A polêmica sobre os jesuítas na Revista do IHGB e a política Imperial (1839-1886). 1ㄹẹed., São Paulo: Paco Imperial, 2013.

DUARTE, M.E.L. e PAGOTTO, E.G. (2005). Gênero e Norma, avós e netos, classes e clíticos no final do século XIX. In: C. R. S. Lopes (org.) A Norma Brasileira em Construção - Fatos linguísticos em cartas pessoais do século 19. Rio de Janeiro: Faperj, 2005, p. 67-82.

ECKERT, P. Linguistic Variation as Social Practice. Oxford: Blackwell, 2000. 
ECKERT, P. \& RICKFORD, J.R. Org. Style and Sociolinguistic Variation. $1^{\text {a }}$ ed., New York: Cambridge University Press, 2001.

EISENBERG, José. As missões jesuíticas e o pensamento politico moderno: Encontros culturais, aventuras teóricas. Belo Horizonte: Ed. UFMG, 2000.

ELIAS, Norbert; SCOTSON, John L. Os estabelecidos e os outsiders: sociologia das relações de poder a partir de uma pequena comunidade. Tradução de Vera Ribeiro. Rio de Janeiro: Jorge Zahar, 2000.

FAUSTINO, Evandro. O catolicismo em São Paulo no Segundo Império e o "Dilema da Modernidade". Dissertação de mestrado em História Social. FFLCH/USP, 1991.

FRANCA, S.J., Leonel. O método pedagógico dos jesuítas: o "Ratio Studiorum". Introdução e Tradução. Rio de Janeiro: Livraria Agir Editora, 1952.

FREIRE, Gilberto. Casa-grande \& senzala. Formação da família brasileira sob o regime da economia patriarcal. 17 ed. Rio de Janeiro: José Olympio, 1975.

GAETA, Maria Aparecida Junqueira Viega. Os percursos do ultramontanismo em São Paulo no episcopado de dom Lino Deodato Rodrigues de Carvalho (1873-1894). São Paulo: USP, 1991

GALVES, Charlotte. Ensaios sobre as gramáticas do português. Campinas: Editora da Unicamp, 2001.

GALVES, C.M.C.; BRITTO, H. S.; PAIXÃO DE SOUSA, M. C. The Change in clitic placement from Classical to Modern European Portuguese: Results from the Tycho Brahe Corpus. Journal of Portuguese Linguistics, v. 4, p. 39-67, 2005. Disponível em https://www.academia.edu/1048497, em 28/05/2016.

GALVES, C., and LOBO, T. Ordem dos clíticos. In: LOBO, T., and OLIVEIRA, K., orgs. África à vista: dez estudos sobre o português escrito por africanos no Brasil do século 
XIX [online]. Salvador: EDUFBA, 2009. pp. 174-207. Disponível em http://books.scielo.org, em 27/05/2016.

GALVES, C.; TORRES MORAES, M.A. e RIBEIRO, I. Syntax and morphology in the placement of clitics in European and Brazilian Portugueses. In: Journal of Portuguese Linguistics, 4(2), 2005, p. 143-177.

GRENDI, Edoardo. Repensar a micro-história? In: REVEL, Jacques. Jogos de escalas: a experiência da microanálise. Rio de Janeiro: Editora Fundação Getúlio Vargas, 1998.

GINZBURG, Carlo. Sinais: Raízes de um Paradigma Indiciário. In: Mitos, Emblemas e Sinais: Morfologia e História. Tradução: Federico Carotti - São Paulo: Companhia das Letras, 1989.

. O queijo e os vermes. O cotidiano e as ideias de um moleiro perseguido pela Inquisição. Trad. Betânia Amoroso. São Paulo: Companhia das Letras, 1995.

GODOY, Mahayana. A colocação dos clíticos no ambiente de orações infinitivas introduzidas por preposição no Português Clássico, 2006. Disponível em: http://www.tycho.iel.unicamp.br/ tycho/pesquisa/monografias/MAHAYANA_MC-ICRel.pdf, em 20/10/2014.

HANSEN, João Adolfo. O nu e a luz: cartas jesuíticas do Brasil. Nóbrega - 1549 - 1558. Revista do IEB. São Paulo, n 38, 1995, p.87-119.

A civilização pela palavra. In: LOPES, E. et al. 500 anos de educação no Brasil. Belo Horizonte: Autêntica, 2000, p. 19-41.

. Ratio Studiorum e política católica ibérica no século XVII. In: VIDAL, D. G.\& HILSDORF, M.L.S. Brasil 500 anos: Tópicas em história da educação. São Paulo: Editora da Universidade de São Paulo, 2001, p.13-42. 
HOBSBAWN, Eric. A invenção das tradições. Rio de Janeiro: Paz e Terra, 1984.

KATO, M.A. Pronomes fortes e fracos na gramática do português brasileiro. Revista Portuguesa de Filologia. Vol.XX. Coimbra, p. 101-122.

KOERNER, K. O problema da metalinguagem em historiografia da linguística. Tradução de Cristina Altman, Revista Delta, vol. 12, № 1, 1996.

LABOV, William. Sociolinguistic Patterns. Philadelphia: University of Pennsylvania Press, 1972.

. Estágios na aquisição do inglês standard. In.: FONSECA, M. e NEVES, M. (orgs.). Sociolinguística. Rio de Janeiro: Eldorado, 1974.

. Building on Empirical Foundations. In: Lehmann, W. \& Malkiel, Y. (eds.) Perspectives on Historical Linguistics. Amsterdam: John Benjamins,1982, 17-92.

. Principles of Linguistic Change. Oxford/Cambridge: Blackwell, 1994.

LEITE, Serafim. História da Companhia de Jesus no Brasil. Tomos I e II. Porto: Tipografia Porto Médico, 1938.

LEVA, J. U. A Igreja e os meios para Evangelizar. Revista Eletrônica Espaço Teológico, v. 8, p. 103-123, 2014.

LIMA FILHO, Henrique Espada R. A micro-história italiana: escalas, indícios e singularidades. Rio de Janeiro: Civilização Brasileira, 2006.

LOBO, Tânia. A Colocação dos Clíticos em Português. Duas Sincronias em confronto. Dissertação de mestrado em Linguística Histórica apresentada à Faculdade de Letras da Universidade de Lisboa. Lisboa, 1992. 
- Para uma sociolinguística histórica do português no Brasil: edição filológica e análise linguística de cartas particulares do Recôncavo da Bahia, século XIX. Tese de Doutorado Universidade de São Paulo, 2001.

LOPES, Mauricio M. As faces da modernidade: Arquitetura religiosa nas reformas urbanas de Itu (1873-1916). Dissertação de Mestrado FAU/USP, 2009.

LOYOLA, Inácio de. Exercícios espirituais. Trad. Joaquim F. Pereira. São Paulo: Loyola, 1994.

Constituições da Companhia de Jesus. Trad. Joaquim M Abranches.

Lisboa: s/e, 1975.

MAINGUENEAU, Dominique. Novas tendências em análise do discurso. Campinas, SP: Pontes/Unicamp, 1997.

MANOEL, Ivan Aparecido. Igreja e educação feminina (1859-1919): Uma face do conservadorismo. São Paulo: Editora da Universidade Estadual Paulista, 1996.

MARCUSCHI, L. A. (2006) Repetição. In: JUBRAN, C. C. A. S.; KOCH, I. G. V. (org.) Gramática do Português Culto Falado no Brasil. Vol. I. Campinas: Editora da Unicamp, 2006, p.219-254

MARICONDA, Pablo Rubén. O diálogo de Galileu e a condenação. In: Cadernos de História e Filosofia da Ciência, Campinas, Série 3, v.10, n.1, p.77-160, jan.- jun. 2000

MARTINS, Ana Maria. Clíticos na história do português. Dissertação de doutorado. Faculdade de Letras de Lisboa, 1994.

- Mudança sintática: clíticos, negação e um pouquinho de scrambling.

Estudos linguísticos e Literários, n. 19. Salvador, 1997, pp.129-161.

MATTOS E SILVA, R.V.; MACHADO FILHO, A.V.L. O Português quinhentista : estudos lingüísticos (Orgs.) . - Salvador : EDUFBA; Feira de Santana : UEFS, 2002. 
. A posição dos pronomes pessoais clíticos. In: Gramática do Português.

Lisboa: Fundação Calouste Gulbenkian, 2008.

MICELI, Sergio. A força do sentido. In: Sergio Miceli. (Org.). A economia das trocas simbólicas. São Paulo: Editora Perspectiva, 1974, v. , p. I-LXI.

A elite eclesiástica brasileira (1890-1930). Rio de Janeiro: Bertrand-

Brasil, 1988.

MONTEVERDE, Emilio Achilles. Manual Encyclopédico para uso das escolas d'instrucção primaria. 8 8 $^{\mathrm{a}}$ ed. revista e melhorada. Lisboa: Imprensa Oficial, 1865.

MORENO, Montserrat; PEREIRA, Viviane. Colégio São Luís 140 anos: a educação e os jesuítas no Brasil - São Paulo: Tempo \& Memória, 2007.

MURAKAWA, C.A.A. Léxico e gramática no diccionario da Lingua Portugueza (1813) de António de Morais Silva. ALFA, São Paulo, 50(2): 2006, p.55-67.

MURRAY, Stephen O. Theory Groups and the Study of Language in North America: a social history. Vol.69. Amsterdam: John Benjamins Publishing Company, 1993, p.1-26.

NAMIUTI, Cristiane. Aspectos da História Gramatical do Português. Interpolação, Negação e Mudança. Tese de Doutorado, Campinas: Unicamp, 2008.

NARDY FILHO, Francisco. A cidade de Itu. Vol.1-6, Itu-SP: Ottoni Editora, 1999.

NEVES, L.F. Baêta. O combate dos soldados de Cristo na terra dos papagaios: colonialismo e repressão cultural. Rio de Janeiro: Forense Universitária, 1978.

NOGUEIRA, M.A.(Orgs.). A escolarização das elites: um panorama internacional da pesquisa. Petrópolis: Vozes, 2002, p. 11-28.

OLIVEIRA, Marilza de. Pluricentrismo na Arena Linguística. In: Augusto Soares da Silva; Amadeu Torres; Miguel Gonçalves. (Orgs.). Pluricentric Languages: Linguistic Variation 
and Sociocognitive Dimensions. 1ed. Braga: Universidade Católica Portuguesa, 2011, p. 681-694.

- Colocação pronominal: índice social da diferença. Comunicação apresentada no SINEFIL, UFMS, 2013.

. Posição dos clíticos no xadrez linguístico da virada do século XX. XVII Congresso Internacional da Associação de Linguística e Filologia da América Latina (ALFAL), UFBA. 2014.

. A naturalização dos portugueses e a invenção da marca identitária.

In: FIGUEIREDO, C.; ARAÚJO, E. (Orgs.) Diálogos com Ribeiro. Sobre a gramática e história da língua portuguesa. Salvador: Edufba, 2015

PAGOTTO, Emílio. A posição dos clíticos em português: um estudo diacrônico. Dissertação de mestrado, Campinas: Unicamp, 1992.

. Clíticos, mudança e seleção natural. In: ROBERTS, I \& KATO, M. (Orgs.).

Português Brasileiro: uma viagem diacrônica. Campinas: Editora da Unicamp, p.185-206, 1993.

Norma e Condescendência; Ciência e Pureza. In: Línguas e Instrumentos Linguísticos. Campinas: Pontes Editores/HIL, p. 49-68, 1998.

. Rui Barbosa e a crise normativa brasileira. In: D. Callou e A. Barbosa (orgs.) A norma brasileira em construção: cartas a Rui Barbosa (1886 a 1899). Rio de Janeiro. Fundação Casa de Rui Barbosa, p.105-166, 2011.

PAGOTTO, E. e DUARTE, M.E. Gênero e norma: avós e netos, classes e clíticos no final do século XIX. In: Célia Regina dos Santos Lopes (Org.) A Norma Brasileira em Construção: Fatos linguísticos em cartas pessoais do século XIX. Rio de Janeiro: FAPERJ, 2005. 
PAIVA, J.M. \& PUENTES, R.V. A proposta jesuítica de educação: uma leitura das Constituições. Comunicações. Piracicaba, ano 7, n.2, p. 101-118, novembro, 2000.

PEREIRA, Hélcius. A realização do sujeito pela elite paulistana do início do século $X X$ : uma análise em perspectiva Gerativista Trans-sistêmica. Tese de doutorado, FFLCH/USP, 2010.

PEROSA, G. S. Grupos familiares, investimentos educacionais e o mercado escolar em São Paulo. Pro-Posições (Unicamp), Campinas, v. 15, n. 2, p. 61-75, 2004.

PETRONE, M. Thereza Schorer. A lavoura canavieira em São Paulo. Expansão e declínio. (1765-1851). São Paulo: Difusão Europeia do Livro, 1968, p.143.

PIRES, Mário Jorge. Sobrados e Barões da Velha São Paulo. Barueri, SP: Manole, 2006.

PINÇON, Michel; PINÇON-CHARLOT, Monique. A infância dos chefes: a socialização dos herdeiros ricos na França. Tradução de Guilherme João de Freitas Teixeira. In: ALMEIDA, Ana Maria F.; NOGUEIRA, M.A. (Org.). A escolarização das elites: um panorama internacional da pesquisa. Petrópolis: Vozes, 2002. p. 11-28.

REVEL, Jacques. Jogo de Escalas: a experiência da microanálise. Rio de Janeiro: Editora Fundação Getúlio Vargas, 1998.

RIBEIRO, Priscilla Barbosa. A ordem de constituintes sentenciais no português paulista. Dissertação de mestrado, FFLCH/USP, 2001.

- Língua e sociedade: a ordem na escola republicana paulista. Tese doutorado, FFLCH/USP, 2015.

SAHLINS, Marshall. Ilhas de História.1 $1^{a}$ ed. Rio de Janeiro: Jorge Zahar Editor, 1990. Metáforas históricas e realidades míticas: estrutura nos primórdios da história do reino das Ilhas Sandwich. Rio de Janeiro: Jorge Zahar Ed., 2008. 
SANTOS SILVA, Hosana dos. O lugar da língua na São Paulo transformada: os usos linguísticos de intelectuais republicanos paulistas. Tese de doutorado. FFLCH/USP, 2012.

SCHEI, Ane. A colocação pronominal na língua literária contemporânea do português brasileiro. Stokholms Universitet. Tese de doutorado, 2000.

. A Colocação pronominal do século XIX: a língua literária brasileira. São Carlos: Pedro \& João editores, 2010.

SCHIMIDT, Gladis Maria. Inventário comentado do acervo antigo da biblioteca do Colégio jesuíta São Luís, São Paulo. (mimeo).

SCHWARCZ, Lilia Moritz. O Império em Procissão: Ritos e símbolos do Segundo Reinado. Rio de Janeiro: Jorge Zahar Ed., 2001

TARALLO, Fernando. Diagnosticando uma Gramática Brasileira: o Português d'Aquém e d'Além-mar ao Final do Século XIX. In: Roberts, I \& Kato, M. Português Brasileiro: Uma viagem diacrônica. Campinas: Editora da Unicamp, 1993.

TELES, Fernanda Alvarenga. O sistema de normas e valores dos Grupos Escolares paulistas: a naturalização da ênclise. Dissertação de mestrado. FFLCH/USP, 2014.

VILAR, Socorro de Fátima Pacífico. A invenção de uma escrita: Anchieta, os jesuítas e suas histórias. Tese de doutorado. FFLCH/USP,1999.

WEINREICH, Weinreich; LABOV, William; HERZOG, Marvin. (1968). Empirical Foundations for Theory of Language Change. In: LEHMANN, Paul; MALKIEL, Yakov. (eds.) Directions for Historical Linguistics. Austin: University of Texas Press: 95-188.

WERNET, Augustin. Os primórdios do ultramontanismo em São Paulo (1851-1906): Perspectivas de Pesquisa. Sociedade Brasileira de Pesquisa História (SBPH). Anais da IV Reunião São Paulo,1985. 
A Igreja Paulista no século XIX. Ensaios 120. Ed. Ática, São Paulo, 1987.

WRIGHT, JONATHAN. Os Jesuítas: missões, mitos e histórias. Rio de Janeiro: Relume Dumará, 2006.

ZUMTHOR, Paul. A letra e a voz. A "literatura" medieval. São Paulo: Companhia das Letras, 1993. 


\section{ANEXOS}

Tabela de percentuais para gráfico 4- Ênclise em orações infinitivas preposicionadas Escritores portugueses oitocentistas

\begin{tabular}{|l|c|c|c|c|c|}
\hline & A. Garrett & $\begin{array}{c}\text { A. } \\
\text { Herculano }\end{array}$ & C.C. Branco & $\begin{array}{c}\text { E. de } \\
\text { Queirós }\end{array}$ & F. Pessoa \\
\hline A & $100 \%$ & $100 \%$ & $100 \%$ & $100 \%$ & $100 \%$ \\
\hline DE & $4 \%$ & $2,3 \%$ & $11,6 \%$ & $0 \%$ & $4 \%$ \\
\hline PARA & $4,7 \%$ & $0 \%$ & $0 \%$ & $0 \%$ & $0 \%$ \\
\hline Outras & $0 \%$ & $0 \%$ & $0 \%$ & $0 \%$ & $30 \%$ \\
\hline
\end{tabular}

Tabela de percentuais para gráfico 5: Ênclise em orações infinitivas preposicionadas Escritores brasileiros

\begin{tabular}{|c|c|c|c|c|c|}
\hline & J.Alencar & A.Azevedo & M.Assis & L.Barreto & M.Andrade \\
\hline A & $76 \%$ & $96,5 \%$ & $34,5 \%$ & $39,2 \%$ & $11,4 \%$ \\
\hline DE & $87,5 \%$ & $87,5 \%$ & $40 \%$ & $50 \%$ & $11,8 \%$ \\
\hline PARA & $100 \%$ & $100 \%$ & $93,8 \%$ & $64,7 \%$ & $12,5 \%$ \\
\hline Outras & $100 \%$ & $50 \%$ & $50 \%$ & $16,7 \%$ & $0 \%$ \\
\hline
\end{tabular}

Adaptado de Oliveira (2011) 
Tabela de percentuais gráfico 6 - Ênclise em infinitivas preposicionadas Correspondências de circulação pública escritas no Brasil

\begin{tabular}{|c|c|c|c|}
\hline & Século XVIII & $1850-1879$ & $1880-1910$ \\
\hline A & $100 \%$ & $84 \%$ & $100 \%$ \\
\hline DE & $20 \%$ & $65 \%$ & $75 \%$ \\
\hline PARA & 0 & $53 \%$ & $93 \%$ \\
\hline
\end{tabular}

Adaptado de Oliveira (2013)

Tabela de percentuais gráfico 7 - Ênclise em orações infinitivas preposicionadas Intelectuais paulistas

\begin{tabular}{|c|c|c|c|c|}
\hline & Alberto Sales & Campos Salles & Prudente de & Rodrigues \\
& & & Morais & Alves \\
\hline DE & $100 \%$ & $100 \%$ & $100 \%$ & $53,3 \%$ \\
\hline A & $100 \%$ & $100 \%$ & $100 \%$ & $73,3 \%$ \\
\hline PARA & $94,7 \%$ & $84,6 \%$ & $85,7 \%$ & $56,5 \%$ \\
\hline
\end{tabular}

Adaptado de Santos Silva (2012) 
Tabela percentuais para gráfico 8 - Colocação pronominal em orações infinitivas introduzidas pelas preposições "de" e "para"

\begin{tabular}{|c|c|c|c|c|c|c|c|c|}
\hline & \multicolumn{2}{|c|}{ Século XVI } & \multicolumn{2}{c|}{ Século XVII } & \multicolumn{2}{c|}{ Século XVIII } & \multicolumn{2}{c|}{ Século XIX } \\
\hline & Próclise & Énclise & Próclise & Énclise & Próclise & Énclise & Próclise & Énclise \\
\hline DE & $98,2 \%$ & $1,8 \%$ & $72,7 \%$ & $27,3 \%$ & $61,4 \%$ & $38,6 \%$ & $75,8 \%$ & $24,2 \%$ \\
\hline PARA & $98,1 \%$ & $1,9 \%$ & $79,5 \%$ & $20,5 \%$ & $72,6 \%$ & $27,4 \%$ & $100 \%$ & $0 \%$ \\
\hline
\end{tabular}

Adaptado de Godoy (2006)

Tabela percentuais para gráfico 9 -Ênclise em orações infinitivas introduzidas por preposição

Escritores setecentistas portugueses

\begin{tabular}{|c|c|c|c|c|c|c|c|}
\hline & $\begin{array}{l}\text { Manuel } \\
\text { da } \\
\text { Costa }\end{array}$ & $\begin{array}{l}\text { Vieira - } \\
\text { Sermões }\end{array}$ & $\begin{array}{l}\text { Vieira - } \\
\text { Cartas }\end{array}$ & $\begin{array}{l}\text { F. M. } \\
\text { Melo }\end{array}$ & $\begin{array}{l}\text { A. } \\
\text { Chagas }\end{array}$ & $\begin{array}{l}\text { M. } \\
\text { Bernardes }\end{array}$ & $\begin{array}{l}\text { J.C. } \\
\text { Brochado }\end{array}$ \\
\hline$A$ & $87,5 \%$ & $37 \%$ & $20 \%$ & $75 \%$ & $100 \%$ & $93 \%$ & $77 \%$ \\
\hline $\mathrm{DE}$ & $0,4 \%$ & $0 \%$ & $0 \%$ & $23 \%$ & $40 \%$ & $37 \%$ & $32,5 \%$ \\
\hline PARA & $0 \%$ & $0 \%$ & $0 \%$ & $16 \%$ & $30 \%$ & $17 \%$ & $70 \%$ \\
\hline
\end{tabular}

Adaptado de Godoy (2006) 